UNIVERSIDADE DE SÃO PAULO

FACULDADE DE ARQUITETURA E URBANISMO

PROGRAMA DE PÓS-GRADUAÇÃO EM ARQUITETURA E URBANISMO

SAMIRA MARGOTTO

Fluxos e refluxos

São Paulo

2018 


\section{SAMIRA MARGOTTO}

\section{Fluxos e refluxos}

Exemplar revisado e alterado em relação à versão original sob a responsabilidade da autora e anuência do orientador

Tese apresentada à Faculdade de Arquitetura e Urbanismo da Universidade de São Paulo para a obtenção do título de Doutor em Arquitetura e Urbanismo.

Área de Concentração: Projeto, Espaço e Cultura

Orientação: Prof. Dr. Agnaldo Aricê Caldas Farias 
Autorizo a reprodução e divulgação total ou parcial deste trabalho, por qualquer meio convencional ou eletrônico, para fins de estudo e pesquisa, desde que citada a fonte.

\section{Catalogação na publicação \\ Serviço de Biblioteca e Documentação}

Faculdade de Arquitetura e Urbanismo da Universidade de São Paulo

FICHA CATALOGRÁFICA

Margotto, Samira

Fluxos e refluxos / Samira Margotto; orientador, Agnaldo Aricê Caldas Farias - 2018. $211 \mathrm{f}$.

Tese (Doutorado em Arquitetura e Urbanismo) - Programa de Pós-graduação em Arquitetura e

Urbanismo, Universidade de São Paulo, São Paulo, 2018

Versão original

1. Arte e democracia. 2. Centro e periferia. 3. Intervenção Urbana. 4. Espírito Santo. I. Farias, Agnaldo Aricê Caldas, orient. II Título. 
Nome: MARGOTTO, Samira

Título: Fluxos e refluxos

Tese apresentada à Faculdade de Urbanismo e Arquitetura da Universidade de São Paulo para obtenção do título de Doutor em Arquitetura e Urbanismo.

Aprovado em: 25 de junho de 2018.

\section{Banca Examinadora}

Prof. Dr. Agnaldo Aricê Caldas Farias (Orientador)

Prof. (a) Dr.(a) Maria Cecília França Lourenço

Instituição: Universidade de São Paulo

Prof.(a) Dr.(a) Aparecido José Cirilo

Instituição: Universidade Federal do Espírito Santo

Prof.(a) Dr.(a) Marilúcia Bottallo

Instituição: Centro Universitário Belas Artes de São Paulo

Prof.(a) Dr.(a) Moema Lúcia Martins Rebouças

Instituição: Universidade Federal do Espírito Santo 
Para meu pai, por suas inúmeras histórias.

Para minha mãe, por lutar com garra por suas convicções.

Para Cristiano, pelos infinitos cuidados e compreensão desmedida. 


\section{AGRADECIMENTOS}

Ao adorável Agnaldo Farias, que conduziu a orientação com competência, leveza e uma paciência infinita.

À Maria Cecília França Lourenço (Ciça) e Priscila Rossinetti Rufinoni (Piti), membros da banca do exame de qualificação, por terem apontado caminhos e descaminhos e ensinado a urdir avessos.

Aos competentes membros da banca examinadora: Ciça, Marilúcia, Moema e Cirilo.

Aos professores da USP, tanto no mestrado quanto no doutorado, com quem tive aulas inesquecíveis como Agnaldo Farias, Tadeu Chiarelli, Dária Jaremtchuk, Giselle Beiguelman, Maria Cecília Lourenço, Ana Mae Barbosa, Annateresa Fabris, Celso Favaretto, Evandro C. Jardim e Mario Perniola, dentre outros. E também os da graduação, na UFES, hoje, amigos, como José Cirilo e Maria das Graças Coelho Rangel. Sublinhando ainda, à inesquecível Ana Maria, professora no primário. Não recordo seu nome completo, apenas da lição aprendida. Ela promovia disputas entre os alunos e o vencedor ganhava prêmios cobiçados, como um chocolate. Frequentemente, o brinde era concedido ao aluno com menos recursos e não ao vencedor nos critérios estabelecidos. $O$ sentimento de injustiça na época, anos depois, foi convertido na certeza que, se sua aptidão para promover torneios pode ser questionada, sua sensibilidade não.

Ao Programa de Pós-Graduação em Arquitetura e Urbanismo da FAU/USP, seus professores, técnicos e demais funcionários, sempre prestativos e competentes.

À Teresa Norma Tommasi, Tereza Giuberti, Denise Carvalho, Luiz Paraguassú, Ciça Oliveira, Bernadette Rubim, Piatan Lube, Marcelo Gandini, dentre outros, pelos depoimentos formais ou informais, utilizados ou guardados para pesquisas futuras.

Aos colegas da SEMC/PMV, especialmente, Maria Helena Signorelli, por apoiar incondicionalmente os infindáveis pedidos do setor de artes e, Maria Helena Lindenberg, que assumiu com garra a coordenação da Casa Porto das Artes Plásticas. Aos amigos e colegas de trabalho como Carolina Corres, Raquel Paternostro, Melissa Passamani, Bruna Meriguette, Breno Bricio, Beatriz Sodré, Fabíola Menezes, Melissa Guizzardi, Victor Monteiro e Raphael Araújo.

Aos adoráveis amigos de todas as horas: Josué Vasconcelos, Juliano Mendes Carneiro, Valéria Falchetto, Sandra Batista, Angela Faria, Andressa Sily, Glauco Frizzera, Luís Kifier, Vera Colodetti, Isis Samorini, José Gomes, Juliana Zucollotto, Idone Bringhenti, Tárcia Bringhenti, Denise Vasconcelos, Berenice Vianna, Tânia Noronha, Luciano Lavagnolli, Célia Ribeiro, José Gomes, Marielle Vasconcellos, Andrea Bernardino, Gabi King, Stael Magesck, Marinalva, Vitória, Caio e, em especial, à queridíssima Piti e ao Éder, pelas conversas e observações sobre a vida e a tese. Por seu afeto e senso apurado de justiça, agradeço à Albertina Leite (in memoriam), minha querida Tina, seu marido e sua filha Teresinha.

Aos amigos de Rondônia e colegas de trabalho da UNIR: Clotilde Peruffo, Wandes Leão, Gabriel Bicho, Osvaldo Augusto de Oliveira, Felipe Paros, Edison Arcanjo, Pritama Morgado e André Rigatti.

Aos meus amados familiares: Cristiano, Sandy, Sérgio, Luiza, João, Lilia, Mara, Juninho, Roni, Toninho, Camila, Alice, Alina, Cidinha, Henrique, Vítor, mamãe e papai. 
A mesma sociedade que cria, reproduz e multiplica as diferenças cria os meios de maquiagem e mascaramento dessas diferenças, que põe a sua manifestação e seu exercício como direito numa tensão permanente, tendente a anular a força identitária que a diferença contém (MARTINS, 2014, p. 169). 


\section{RESUMO}

MARGOTTO, Samira. Fluxos e refluxos. 2018. $211 \mathrm{f}$. Tese (Doutorado em Arquitetura e Urbanismo) - Faculdade de Arquitetura e Urbanismo, Universidade de São Paulo, São Paulo, 2018.

Esta tese procurou contextualizar e analisar as reverberações, em Vitória, capital do Espírito Santo, dos debates que movimentaram o campo artístico contemporâneo, sobretudo, a partir da década de 1990, vinculando os termos arte e democracia. Tal vínculo pode ser associado tanto à emergência de um vocabulário novo no universo da arte (participação, colaboração, extradisciplinaridade etc.) quanto às expectativas criadas em torno da noção de globalização e das novas possibilidades de comunicação propiciadas pela internet. Embora seu caráter retórico ou apenas potencial já tenha sido apontado em estudos críticos, somente nos últimos anos isso ficou notório. A tese adotada nesta pesquisa, portanto, é a de que os mecanismos democráticos amplamente difundidos na virada do milênio, ao contrário de sua aparente função transformadora, atuavam como formas camufladas de apaziguamento, preservando o estrato hierárquico clássico. 0 recorte espacial selecionado para a discussão foi uma capital periférica brasileira, enquanto o recorte temporal considerou que um momento expressivo dos debates envolvendo arte e democracia em Vitória ocorreu na primeira década do século XXI. Adotando as ações e projetos desenvolvidos por coletivos e pelo poder público como guia, identificando suas referências, propósitos e limitações impostas ou autoimpostas, em cada um dos capítulos, o microcosmo do campo artístico capixaba constituiu um exemplo emblemático de que quanto mais distante dos pontos hegemônicos se observam tais práticas democráticas, tanto internacionais quanto nacionais, melhor podem ser detectados seus traços míticos, entre as quais a noção de que as fronteiras entre centro e periferia estavam sendo redesenhadas.

Palavras-chave: Arte e democracia. Centro e periferia. Ações interventivas. Espírito Santo. 
MARGOTTO, Samira. Fluxes and Refluxes. Sao Paulo. 2018. 211 pages. Dissertation (PhD in Architecture and Urbanism) - Architecture and Urbanism College, University of Sao Paulo, Sao Paulo, 2018.

This dissertation sought to both contextualize and analyze the reverberations in Vitória, Espirito Santo's capital city, of the debates that moved the contemporary artistic field, especially since the 1990s, linking the terms Art and democracy. Such a link can be associated with both the emergence of a new vocabulary in the art universe (participation, collaboration, extra-disciplinarity etc.), and the expectations created around the notion of globalization and the new possibilities of communication provided by the Internet. Although its rhetorical or just potential character has already been pointed out in critical studies, it has only become apparent in recent years. The thesis adopted in this research, therefore, is that democratic mechanisms widely diffused at the turn of the millennium, contrary to their apparent transforming function, acted as camouflaged forms of appeasement, preserving the classical hierarchical stratum. The spatial cut selected for the discussion was a Brazilian peripheral capital, while the temporal cut considered that the most expressive moment of the debates involving art and democracy in Vitória occurred in the first decade of the 21st century. By adopting the actions and projects developed by art collectives and by the public sector as a guide, the identification of references, purposes and limitations imposed or self-imposed in each of the chapters, the microcosm of the art field of Espirito Santo was an emblematic example that the more distant from the hegemonic points one observes such democratic practices, both international and national, the better its mythical features can be detected, including the notion that the boundaries between center and periphery were being redrawn.

Keywords: Art and democracy. Center and periphery. Intervention actions. Espírito Santo. 


\section{LISTA DE FIGURAS}

Figura 01 - Festival Digitofagia, em São Paulo

Figura 02 - Intervenção na fachada do Edifício das Fundações

Figura 03 - Instalação no interior da Galeria Homero Massena

Figura 04 - Montagem da exposição dos registros do multipliCIDADE 2006

Figura 05 - Ilustração do texto dos bastidores do Festival de Baixa-resolução

Figura 06 - Mapa de riscos ambientais, de Camila Mello (RS)

Figura 07 - Barato é aqui, de Pedro Olaia (PA)

Figura 08 - Página do jornal Folha de S. Paulo

Figura 09 - Abertura do $7^{\circ}$ Salão do Mar

Figura 10 - Varal, de Lourival Cuquinha

Figura 11 - Performance da designer Vera Colodetti

Figura 12 - Performance da designer Stael Magesck

Figura 13 - Obra iluminada e a performer mesclada ao público ao fundo

Figura 14 - Imagem disponibilizada do Armazém 5

Figura 15 - Imagem disponibilizada do Armazém 5

Figura 16 - Imagem disponibilizada do Armazém 5

Figura 17 - Imagem disponibilizada do Armazém 5

Figura 18 - Caximiti, de Isadora Bonder

Figura 19 - Interação em Pororoca 01, de Ana Gastelois

Figura 20 - Língua, de Raquel Baelles

Figura 21 - Horizonte recortado, para localidades não-litorâneas, de Miro Soares

Figura 22 - Fumaça de Resgate, de Camila Sposati

Figura 23 - Banheirinho do Cais, de Herbert Pablo

Figura 24 - Pirata, Tubarão e Sereia, de André Burian

Figura 25 - Detalhe de Varal, de Lourival Cuquinha

Figura 26 - Imagem do projeto de Piatan Lube.

Figura 27 - Resquícios de Caminho das águas

Figura 28 - Montagem da obra Você vê?

Figura 29 - Você vê?

Figura 30 - Trecho selecionado pela Comissão de Organização

Figura 31 - Panorâmica do trecho selecionado que constava no site

Figura 32 - Panorâmica do trecho selecionado que constava no site

Figura 33 - Panorâmica do trecho selecionado que constava no site

Figura 34 - Confecção do molde a partir da escultura original

Figura 35 - Transporte da obra O Retorno de Arariboia

Figura 36 - Herbert Pablo executando Folhetim Sereia

Figura 37 - Folhetim Sereia, de Herbert Pablo

Figura 38 - O Silêncio do Martelo, de Fabrício Carvalho

Figura 39 - À esquerda a proposta de Jo Name e à direita a versão revisada

Figura 40 - ATENÇÃO: ARTE, de Jo Name

Figura 41 - grandePEQUENAcatraia, de Marcelo Gandini

Figura 42 - Tags de Folhetim Sereia

Figura 43 - Marí(n)timo, de Melina Almada. No detalhe o manual

Figura 44 - Proposta inicial de Marí[n]timo

Figura 45 - Plus Ultra, 2007 -..., de Oriana Duarte

Figura 46 - Plus Ultra, 2007 -..., de Oriana Duarte 
Figura 47 - Nós vemos a cidade como a cidade nos vê, de Heraldo Ferreira

Figura 48 - Imagem do projeto de Heraldo Ferreira.

Figura 49 - Interpelação nos abrigos de ônibus (Teatro Invisível)

Figura 50 - 0 Retorno de Arariboia

Figura 51 - Imagens do projeto Líquidas Fronteiras, de Lucimar Bello

Figura 52 - Projeção de Líquidas Fronteiras, de Lucimar Bello

Figura 53 - Imagem do projeto ATENÇÃO : ARTE, de Jo Name

Figura 54 - Ego trip pré-sal, de João Wesley e Sandro de Souza

Figura 55 - João Wesley e Sandro de Souza entregando buttons aos transeuntes

Figura 56 - Button de Ego Trip Pré-sal

Figura 57 - Do pó ao pó, de Laerte Ramos

Figura 58 - Exibição do vídeo Plus Ultra, de Oriana Duarte 


\section{LISTA DE ABREVIATURAS E SIGLAS}

ABRAPLEX - Associação Brasileira de Multiplex

ACMSTC - Arte Contemporânea no Movimento dos Sem-Teto do Centro

ADEPI - Associação de Defesa da Propriedade Intelectual

APCM - Associação Antipirataria de Cinema e Música

APDIF - Associação Protetora dos Direitos Intelectuais Fonográficos

AFPES - Associação dos Funcionários Públicos do Espírito Santo

CCJE - Centro de Ciências Jurídicas e Econômicas

CEMUNI - Célula Modular Universitária

CODESA - Companhia Docas do Espírito Santo

COMORG - Comissão Organizadora

CPF - Conselho, Plano e Fundo de Cultura

EIA - Experiência Imersiva Ambiental

EREA - Encontro Regional de Estudantes de Engenharia e Arquitetura

FACITEC - Fundo de Apoio à Ciência e Tecnologia

FLÔ - Festival do Olhar Livre Creative Commons

IBAMA - Instituto Brasileiro do Meio Ambiente e dos Recursos Naturais Renováveis

LEENA - Laboratório de estudos e ensino da arte

MAES - Museu de Arte do Espírito Santo Dionísio Del Santo

MAM/BA - Museu de Arte Moderna da Bahia

MAM/SP - Museu de Arte Moderna de São Paulo

MASP - Museu de Arte de São Paulo Assis Chateaubriand

MFA - Master of Fine Arts

MinC - Ministério da Cultura

MIS - Museu da Imagem e do Som de São Paulo

MPAA - Motion Picture Association of America

OTAN - Organização do Tratado do Atlântico Norte

PALCA - Projeto de área Livre de Cultura e Arte

PCC - Primeiro Comando da Capital

PIB - Produto Interno Bruto

PMV - Prefeitura Municipal de Vitória

SECULT - Secretaria de Cultura do Estado do Espírito Santo

SEMC/PMV - Secretaria Municipal de Cultura da Prefeitura de Vitória

SINDIAPPES - Sindicato dos Artistas Plásticos Profissionais do Espírito Santo

SPDC - Secretaria de Produção e Difusão Cultural

UFES - Universidade Federal do Espírito Santo 


\section{Sumário}

Introdução, 14

CAPÍTULO 1

AÇÕES, INTENÇÕES E DISJUNÇÕES: INICIATIVAS INDEPENDENTES, 21

1.1. PARTICIPAÇÃO/COLABORAÇÃO: disciplinaridade e extradisciplinaridade, 31

1.2. INICIATIVAS INDEPENDENTES E CIRCUITO INSTITUÍDO, 43

1.2.1 Regras, conformações e antagonismos

1.2.2 Desafio e descrença

1.3. RELACCÕES: COLETIVO PARA ALÉM DOS SEUS INTEGRANTES, 63

1.4. CONFRONTOS, DEMARCAÇÕES E ASSOCIAÇÕES, 76

1.5. INTANGIBILIDADE/INVISIBILIDADE, 89

\section{CAPÍTULO 2}

CONSTRUINDO NAS BRECHAS, 93

2.1. FORMATOS E FRONTEIRAS, 97

2.2. SEDUZIR E AFERIR, 107

2.2.1. Ações e relações

2.2.2. Demarcações

2.2.3. Público: uma rota entre tantas

2.3. RECONCEITUAÇÕES: ESPAÇOS ALTERNATIVOS E PRODUÇÃO, 122

\section{CAPÍTULO 3}

TRANSBORDAMENTOS E DEMARCAÇÕES, 138

\section{Parte [1] Lançar-se às ruas}

3.1. REVERBERAÇÕES: MODELO E TRANSPOSIÇÃO, 144

3.1.1. Disciplinaridade e "democracia" no "salão do campo ampliado"

3.1.2. Ditames disciplinares e a dinâmica urbana

3.1.3. Leis, normas e obras

3.1.4. Disciplina: fluxos e suportes

3.1.5. Um grande laboratório: interfaces com o múltiplo

Parte [2] Apropriações do efêmero no cenário contemporâneo: apontamentos, 180

3.2. ROTINA E EXCEÇÃO TEMPORÁRIAS, 183

3.3. MATERIAL E IMATERIAL TEMPORÁRIO, 190

3.4. TRANQUILIDADE E INTRANQUILIDADE TEMPORÁRIAS, 195

3.5. EFÊMERO: CESSÃO E EXCEÇÃO, 197

Referências, 199 


\title{
Introdução
}

\begin{abstract}
Para corrigir uma indiferença natural, fui colocado a meio caminho entre a miséria e o sol. A miséria impediu-me de acreditar que tudo vai bem sob o sol e na história; o sol ensinou-me que a história não é tudo. Mudar a vida, sim, mas não o mundo do qual eu fazia minha divindade (CAMUS, 1995, p.18).
\end{abstract}

A utilização dos termos fluxos e refluxos ${ }^{1}$ para intitular esta pesquisa parte da tese de que os mecanismos democráticos amplamente difundidos, sobretudo, a partir da década de 1990, ao contrário de sua aparente função transformadora, atuaram como formas camufladas de apaziguamento, preservando ou tensionando de forma tímida, estratos hierárquicos clássicos. Os fluxos do título, vistos em retrospecto, não são tão entusiasmantes quanto foram apregoados no período em que, às expectativas criadas em torno da noção de globalização e das novas possibilidades de comunicação propiciadas pela internet anunciavam mobilidade, efemeridade, liquidez, relações mais igualitárias. Embora seu caráter retórico ou apenas potencial tenha sido apontado em estudos críticos desde 0 período inicial, somente nos últimos anos isso ficou notório. O retorno dos discursos nacionalistas, as medidas coercitivas do uso da comunicação em rede servem para exemplificar o que pode ser denominado de refluxos conservadores que ficaram cada vez mais explícitos. Porém, nesta pesquisa, a opção foi localizar no interior das ações e projetos analisados seu caráter mais potencial que efetivo, sem recorrer aos desdobramentos posteriores, tanto no âmbito macro quanto no local.

Os fluxos desse panorama geral ecoaram no campo artístico contemporâneo. Em torno dos termos arte e democracia, ocorreu à emergência de um vocabulário novo, no qual, as palavras participação, colaboração e extradisciplinaridade ganharam amplitude com ações que congregavam artistas, ativistas e comunidade procurando tensionar os limites atribuídos ao exercício da arte e seus protagonistas tradicionais. Ademais, tanto no âmbito dos grandes eventos internacionais (a Documenta de Kassel, por exemplo) quanto em tentativas brasileiras promovidas por artistas ou instituições (os mapeamentos realizados pelo Projeto Rumos do Instituto Itaú Cultural, a nacionalização dos salões de arte, a reformulação dos formatos das ações artísticas etc.) a noção de diluir fronteiras, de ir além de demarcações historicamente assentadas sustentavam a noção dos fluxos apregoados no contexto da apologia em torno do termo pós-colonial, do fim da bipolarização entre duas potências mundiais que

1 O título faz referência à obra de Francis Bacon (1561-1626), Do fluxo e refluxo do mar, escrita entre 1611 e 1619. Trata-se de um conjunto de seis ensaios que representa, segundo Pablo Mariconda, "[...] um caso exemplar de como uma reflexão construída a partir da visão mágico-naturalista [...] pode, mesmo assim, integrar-se aos esforços de solução da época, alinhando-se ao seu tempo". MARICONDA, Pablo Rubén. Francis Bacon e as marés: a concepção da natureza e o mecanismo. Scientiæ zudia, São Paulo, v. 5, n. 4, p. 501-19, 2007, p.517. 
marcou o período da Guerra Fria, da proclamação da era da globalização, aliados à integração da cultura digital e a hegemonia do neoliberalismo econômico.

Sabe-se que a noção de inclusão, presente tanto na relação dos centros com as periferias quanto das periferias com as subperiferias, fez parte da retórica disseminada a partir da década de 1990. Tanto as omissões quanto as tentativas de enxertar os excluídos são vinculadas e dependentes da forma que o discurso é estruturado e, consequentemente dos pressupostos que ele carrega. Mais do que as respostas, o que importa é quem faz e como são feitas as perguntas, pois serão elas que delinearão sua supervisão e controle. Assim, as concessões circunscreveram, sobretudo, inclusões que são convenientes. $O$ porquê de sua conveniência nesse período é parte integrante da disseminação do termo "democracia" em suas distintas esferas que são abordadas nesta tese.

Tendo como eixo o argumento de que os mecanismos democráticos, difundidos na virada do milênio, longe de abalar efetivamente hierárquicas tradicionais, serviram, grosso modo, como meios de maquiagem e mascaramento dessas diferenças - conforme sintetizou José de Souza Martins na epígrafe desta pesquisa - considerando ainda que, a feição mítica das práticas democráticas fica mais evidente quando examinada distante dos centros hegemônicos, tanto internacionais quanto nacionais, o locus da observação selecionado foi Vitória, capital do Espírito Santo.

Pertencente à região Sudeste, junto com São Paulo, Rio de Janeiro e Minas Gerais, e tendo o estado da Bahia como fronteira ao norte, próximo, portanto, dos polos econômicos e culturais de referência no Brasil, o Espírito Santo não pode ser disposto no caso extremo do que Gerardo Mosquera (2003) denominou de "zonas de silêncio", fora de todo o circuito. Todavia, não deixa de ser uma capital periférica de um país, situado na periferia do capitalismo. A localização geográfica do Espírito Santo ao invés de beneficiá-lo, promovia parâmetros de difícil alcance para os capixabas. Se a região sudeste lidera as estatísticas nacionais, concentrando o maior contingente populacional e possuindo o maior Produto Interno Bruto (PIB) do país, os índices relativos ao Espírito Santo sempre apresentaram um nítido contraste com aqueles ostentados por seus vizinhos². Situação que passou por significativas mudanças, a partir de 2003, com as negociações efetuadas pelo governo estadual com a União,

\footnotetext{
2 Sávio Caçador e Antonio Grassi (2011) analisaram as alterações no PIB capixaba em relação ao brasileiro, desde a década de 1970 até o começo do século XXI. Segundo eles, apesar do primeiro ter crescido acima da média nacional, a imensa distância entre a situação desfavorável de desenvolvimento do Espírito Santo em relação aos demais estados da região sudeste, presente desde o período colonial, só passou a apresentar sinais claros de reversão a partir da primeira década do século XXI. CAÇADOR, Sávio B.; GRASSI, Antonio. A evolução recente da economia do Espírito Santo: um Estado desenvolvido e periférico? In: FERRARI, Marcos Adolfo Ribeiro, ARTHMAR, Rogério. Novas leituras sobre a economia do Espírito Santo, Vol.1. Vitória: PPGEco/CORECON-ES, 2011, p.190.
} 
vendendo antecipadamente a receita futura de royalties ${ }^{3}$ do petróleo 4 . Entretanto, as mudanças na estrutura econômica capixaba, favorecidas pelo cenário nacional e internacional do período 5 , não foram transpostas com o mesmo dinamismo para a área cultural.

Em relação ao seu campo artístico e cultural, a Universidade Federal do Espírito Santo (UFES) era (e continua sendo) o único local que oferecia cursos superiores de artes e somente em 2006, passou a ofertar mestrado na área, além disso, até o final da década de $1990^{6}$ não existia nenhum museu de arte na Grande Vitória ${ }^{7}$. Ao expor brevemente aspectos do incipiente sistema de arte capixaba, a pretensão é chamar a atenção para as delimitações nas condições de reflexão, produção e exibição da arte no período que antecede ou coincide com o recorte temporal selecionado, a primeira década do século XXI. Nesse sentido, as ações e projetos adotados como guias deste trabalho, desenvolvidos por coletivos e pelo poder público visaram atualizar o repertório cultural vigente na cidade, dialogando com seu tempo.

3 Os Royalties são uma compensação financeira paga em contrapartida ao direito de explorar a produção. No caso do petróleo no Brasil, segundo consta no site do Senado, "[...] os royalties são cobrados das concessionárias que exploram a matéria-prima, de acordo com sua quantidade. $O$ valor arrecadado fica com o poder público. Segundo a atual legislação brasileira, estados e municípios produtores - além da União - têm direito à maioria absoluta dos royalties do petróleo. A divisão atual é de $40 \%$ para a União, $22,5 \%$ para estados e $30 \%$ para os municípios produtores. Os 7,5\% restantes são distribuídos para todos os municípios e estados da federação". Disponível em: <http://www.senado.gov.br/noticias/agencia/infos/inforoyalties_htm>. Acesso em: 04 abr. 2016.

$4 \quad$ Entretanto, essa venda antecipada - que possibilitou, por exemplo, o pagamento atrasado do funcionalismo estadual - foi questionada pelo governador Renato Casagrande (2011-2015). Segundo ele, a negociação foi "uma grande barbeiragem", visto que os "[...] R $\$ 300$ milhões geraram uma dívida de mais de $\mathrm{R} \$ 1$ bilhão (para o Estado)." DESABAFO ATRASADO. Vitória (ES): Século Diário [Jornal on-line]. 27/05/2015. Disponível em: <http://seculodiario.com.br/23043/14/desabafo-atrasado-1\#>. Acesso em: 04 abr. 2016.

$5 \quad$ Entre 2004 e 2008, o Brasil apresentou forte dinamismo econômico com o crescimento acelerado do comércio internacional, especialmente, em torno da exportação "[...] das commodities - incluindo a atividade extrativa de petróleo e minério de ferro e as indústrias processadoras de matérias primas" (CARNEIRO, 2010, p.10 e 14). Cabe sublinhar que, em 2002, ocorreu o boom dos preços das commodities - o último grande aumento ocorreu na segunda metade da década de 1970 - impulsionado, sobretudo, pelo crescimento excepcional da China (PRATES, 2007, p.335 e 341), e aliado a um conjunto de outros fatores, entre os quais, a "[...] recuperação econômica global, desvalorização do dólar, bolha especulativa fomentada pelas taxas de juros baixas" (PRATES, 2007, p.341). Cf: CARNEIRO, Ricardo. O desenvolvimento brasileiro pós-crise financeira: oportunidades e riscos. Observatório da economia global. №4, agosto de 2010. PRATES, Daniela Magalhães. A alta recente dos preços das commodities. Revista de Economia Política, vol. 27, $n^{0} 3$ [107], pp.323344, julho-setembro/2007, p.336.

$6 \quad$ Em 1998, ocorreu tanto a abertura do Museu Vale do Rio Doce quanto a inauguração do Museu de Arte do Espírito Santo (MAES). Ressalta-se ainda que, em 1999, a Casa Porto das Artes Plásticas iniciou suas atividades, demarcando o começo de um setor dedicado às artes no âmbito do poder público municipal de Vitória.

7 A iniciativa anterior de criação de um museu de arte no Estado foi, não somente particular, como brevíssima: entre 1965 e 1970, o Museu de Arte Moderna do Espírito Santo MAM/ES, foi criado e extinto. Em 08 de setembro de 1965, por iniciativa do artista espanhol Roberto Newman Westmor-Nuffield juntamente com artistas e intelectuais locais, o MAM/ES começou suas atividades, realizando três salões [1966, 1967 e 1968]. Apesar de atraído nomes expressivos do panorama artístico nacional para expor em Vitória, encerrou suas atividades subitamente em 1970. Durante seu primeiro ano, funcionou na casa do artista, entretanto, em março de 1966, o MAM/ES recebeu apoio municipal e estadual, e obteve personalidade jurídica, sendo transferido para outra sede. Ivan Serpa, Aldemir Martins, Fayga Ostrower e Renina Katz, são alguns artistas que participaram dos Salões promovidos pela instituição [RIBEIRO, 2012]. RIBEIRO, Renata. El olvidado mam es y lós espacios expositivos de vitória, brasil. reencontrar la historia. Estudios Historicos/CDHRPyB, IV, n. 8, 2012. 
No primeiro capítulo, o fio condutor da análise foi ações e projetos desenvolvidos pelos coletivos Cine Falcatrua, Maruípe e Entretantos, identificando suas referências, propósitos e limitações impostas ou autoimpostas. Formados no ano de 2004, os integrantes desses grupos eram estudantes da UFES, instituição cultural mais sólida no Espírito Santo. Enquanto, os participantes do Cine Falcatrua eram egressos dos cursos de Jornalismo, Artes e Psicologia, os membros do Coletivo Maruípe e Coletivo Entretantos faziam graduação em artes ou arquitetura. Se os dois últimos questionavam a verticalidade do circuito oficial da arte, mimetizando seus formatos e protocolos, desenvolvendo ações no espaço urbano e tentando incluir Vitória no circuito independente de arte, que passava por um processo exponencialmente contínuo de crescimento nesse período no Brasil, o Cine Falcatrua a priori, não tinha qualquer intenção de estar circunscrito dentro da disciplina artística, direcionando suas ações no sentido de suprir o contexto do circuito de entretenimento contemporâneo no Espírito Santo, que possuía naquele momento, um número reduzido de salas de cinema.

O denominador comum extraído dos trabalhos dos três coletivos e presente na topografia emblemática e contextual da arte contemporânea é 0 viés operacional e simbólico da colaboração/participação entre os integrantes nas ações realizadas e a referência outorgada ao público na partilha dos resultados. A análise dos desdobramentos de suas propostas, desde a concepção até a efetiva realização de seus pressupostos descortinam alguns matizes pertencentes às discussões atuais sobre a incorporação das vias, dispositivos e expedientes artísticos aos meios de produção. Destacadamente, o polo enunciativo estratégico para legitimar a suposta autonomia e independência pode ser pensado a partir da transposição da figura do artista, como produtor individual de objetos, pela noção do artista como colaborador e gerador de situações, enquanto a obra de produto portátil e comercializável foi repensada como projeto em andamento (com começo e fim, em muitas ocasiões, indeterminados) e, o público (anteriormente compreendido como espectador) passou a ser reposicionado como coprodutor ou participante.

Sem descartar ou endossar completamente formulações teóricas desenvolvidas nos grandes centros do capitalismo, em um contexto diametralmente diverso do estudado, procurou-se dialogar, por exemplo, com o posicionamento de Chantal Mouffe, principalmente perante a sua defesa pela necessidade das lutas contra hegemônicas serem realizadas tanto dentro quanto fora das instituições tradicionais da arte. A transposição do debate sobre os benefícios da vinculação ou desvinculação institucional na potencialização do grau de contestação hegemônica, entretanto, para ambientes não estruturados tem sua premência amenizada ou adquire nuances diversas das que ocorrem nos grandes centros. Nos grandes centros do capitalismo, com o cenário artístico composto por um sistema 
estruturado — formado por aparelhos culturais (museus, galerias, centros culturais etc..), mercado de arte e reflexão crítica - a contestação ao hegemônico, dentro ou fora das instituições, parece uma alternativa possível ou mesmo necessária. Por um lado, o artista crítico independente, por dispor de outras vias de manutenção de seu trabalho, encontra eco, positivo ou negativo, no cenário apresentado acima. Por outro lado, as instituições são capazes de fomentar, gerir e divulgar seus próprios aspectos críticos por sua resistência como corpo perene.

Não é à toa, portanto, que questões diversas à contestação da hegemonia institucional pautem a produção contemporânea de cidades de menor porte, como é o caso de Vitória (ES). O panorama do qual Chantal Mouffe parte pressupõe um sistema das artes consolidado, em que, a oposição ao ambiente parece ser uma alternativa viável ou até necessária à expansão ou manutenção do status quo. Porém, em locais à margem do cenário que engendrou a discussão proposta pela autora, a questão que move a aproximação com os espaços institucionais pelos artistas engajados em práticas mais experimentais é pautada, sobretudo, pela necessidade de viabilizar suas produções, para as quais, a relação com as organizações pode figurar como acessório fundamental. Essas e outras questões são abordadas no capítulo inicial, ao analisar a relação dos coletivos Maruípe, Entretantos e Cine Falcatrua com o circuito artístico e cultural capixaba, considerando seus propósitos e limitações.

No segundo e no terceiro capítulo, a análise recai sobre o interesse crescente de artistas, instituições e formuladores de políticas culturais, na década de 1990, de realizar mostras fora dos espaços convencionais, abordar questões sociais e utilizar o espaço urbano para a efetivação de parcela significativa dessas ações. A discussão em torno do termo arte pública, seus territórios e fronteiras, parte do tratamento pioneiro da questão encabeçado pela análise crítica da intersecção entre arte pública e política urbana proposta por Rosalyn Deutsche. As reconfigurações do que tradicionalmente se convencionou denominar arte pública ao longo das últimas décadas e das instâncias que se mobilizaram em torno dessas alterações são abordadas a partir das mudanças nas noções do papel do artista e do público e, também, das funções das instituições de arte e da substituição da noção de arte/objeto por projetos e ações.

Tendo como mote as mudanças efetuadas em um salão regional de arte contemporânea, promovido pelo poder público municipal (intitulado de Salão Capixaba do Mar de 1999 até 2004; designado em 2006 de Salão do Mar e, em 2008, de Salão Bienal do Mar), que culminaram com sua realização nas ruas do centro histórico de Vitória, nesses dois capítulos foram traçados paralelos com outros discursos correntes no período, entre os quais, o que clamava a importância da cultura e das artes no contexto da globalização da economia, projetando e distinguindo cidades ou regiões no mundo 
competitivo e globalizado, além da diluição das distinções entre centro e periferia. No caso brasileiro, foi muito divulgado, por exemplo, que seu mapa artístico estava sendo redesenhado, seu circuito descentralizado. Tais questões são problematizadas cruzando contribuições teóricas com outras de caráter informativo procurando apontar seu caráter mítico.

As tensões políticas presentes em macro e micro disputas, na edição de 2006 do evento, realizado em um armazém portuário, foram amplificadas ou adquiriram outros contornos na edição seguinte do evento, em 2008. Em relação à mostra de 2006, seu o caráter espetacular, ampliou sua visibilidade reforçada pelo local de sua realização e pela variedade de atrações acopladas. Neste, os termos "democracia", "espetáculo" e "consumo" foram fundidos. Na edição de 2008, os dispositivos associados aos debates sobre democracia no plano da arte e a natureza restritiva da tradição modernista foram expandidos. A proposta apresentada no $8^{\circ}$ Salão Bienal do Mar foi dedicada às práticas artísticas que estabelecessem uma relação interdisciplinar com a cidade, seus espaços e habitantes, por meio de projetos temporários ou efêmeros. Os pontos principais, emulados do Madrid Abierto compõe um conjunto que foi, paulatinamente, sendo padronizado na década de 1990 e, extensivamente utilizado, especialmente, na primeira década do século XXI. No terceiro e último capítulo, a discussão, foi dividida em duas partes que se complementam. A primeira, intitulada de "Lançar-se às ruas" foi desenvolvida a partir da seguinte indagação: Por que o entusiasmo em creditar que o espaço urbano constituía um local privilegiado para as discussões que pretendiam debater a noção de democracia no plano artístico?. A segunda parte questiona o porquê que o termo "efêmero" foi incorporado, praticamente, de forma unânime no cenário contemporâneo. Ambas foram motivadas pelos ditames que constavam no edital do $8^{\circ}$ Salão Bienal do Mar.

Além de tensionar a essência dos discursos que topografam o período analisado, ao reunir embates teóricos para abordar exemplos retirados do microcosmo do campo artístico capixaba, esta pesquisa procurou lançar um viés interrogativo às prerrogativas que envolveram e nortearam os termos arte e democracia, mitificando seu potencial de efetivação. 0 quadro aqui traçado pode parecer cético, no entanto, como participante da equipe de organização dos dois eventos institucionais aqui analisados e, acompanhado as condições instáveis que se move a cultura na atualidade, especialmente nos refluxos dos discursos conservadores, ao lançar um olhar retrospectivo sobre o passado recente, tentou-se não recair no conforto de analisá-lo enaltecendo seus feitos, mas adotando uma perspectiva que permitisse compreender seus pontos frágeis, como partes integrantes de um conjunto que, apenas amenizou, sem extirpar hierarquias historicamente construídas. No entanto, é necessário sempre repor a indagação de Maria Cecília França Lourenço que, ao comparar as mudanças efetuadas a partir dos 
anos de 1920 e décadas seguintes no panorama artístico e cultural brasileiro, de olhos postos no presente, indagou: "ações inovadoras contribuiriam para alterar tal cenário sombrio?" (2016, p.76).

Por fim, deve-se sublinhar que, de forma metodológica, optou-se por outorgar a cada capítulo o seu respectivo caráter analítico e conclusivo como forma de aprofundamento em cada um dos pontos específicos, junto ao pensamento crítico que se partilha e se tensiona por meio das inquietações que configuraram a linhagem dessa tese como um todo. 


\title{
CAPÍTUL0 1
}

\section{AÇÕES, INTENÇÕES E DISJUNÇÕES: INICIATIVAS INDEPENDENTES}

\author{
Para resistir, é preciso que a resistência seja como o poder. Tão inventiva, tão móvel, tão \\ produtiva quanto ele. Que, como ele, venha de "baixo" e se distribua estrategicamente \\ (FOUCAULT, 2005, p.241).
}

\begin{abstract}
Sei muito bem - e creio que saiba desde minha infância - que o saber é impotente em transformar o mundo. Talvez eu esteja errado. E estou seguro que estou errado de um ponto de vista teórico, pois eu sei muito bem que o saber transformou o mundo.

Mas se me refiro à minha própria experiência, tenho o sentimento que o saber não pode nada por nós e que o poder político é capaz de nos destruir. Todo o saber do mundo não pode nada contra isso (FOUCAULT, 2004, p.255-256).

A verdadeira tragédia de todo poeta talvez seja a de atingir o mundo só metaforicamente, segundo as regras de uma magia definitivamente limitada na sua apropriação do mundo (PASOLINI, 1983, p.25).
\end{abstract}

Práticas artísticas experimentais de caráter político ou conceitual atuando em oposição às políticas neoliberais e afinadas com os discursos de contraposição do período, se expandiram a partir da década de 1990. Parte considerável desse tipo de produção foi realizada pelos denominados coletivos, que passaram a conceber, por redes virtuais e presenciais de comunicação, estratégias próprias de circulação e mediação de suas produções, em elaborações conjuntas e sem hierarquia processual explícita. As questões lançadas por alguns desses grupos eram diversas, porém, por vezes entrelaçadas, ainda que distinguíveis em sua ênfase. Uma das frentes questionava a verticalidade do circuito oficial da arte, mimetizando, ao mesmo tempo, seus formatos e protocolos; em outra, dialogava com o espaço urbano, em ações desviantes às que estavam sendo desenvolvidas pelo circuito estabelecido; uma terceira enfatizava as questões transversais ao campo artístico, em empreendimentos de caráter extradisciplinar, contribuindo para colocar em foco problemas sociais ou econômicos utilizando, em algumas ocasiões, métodos ativistas. Em todas, porém, um mesmo desejo: o protagonismo em seu tempo e lugar. 
No Brasil, como em outras partes do mundo, esses grupos eram reduzidos numericamente durante os anos de 1990, porém, a partir da primeira década do século XXI8 passaram por um processo exponencialmente contínuo de crescimento, pulverizando-se em um conjunto disperso e diversificado de interesses. Para pensar essas ações, alguns termos são recorrentes nas análises: afinidades, afetos, irreverência, humor, colaboração, participação e compartilhamento estão entre eles. Tais termos são acompanhados, em alguns casos, por palavras de ordem como enfrentamento, interferência, subversão, ativismo, resistência, atitude, insurgência etc.. A emergência desse vocabulário que mescla palavras carismáticas e de confronto é paradigmática para compreender, tanto diversidades dos propósitos desses coletivos quanto para ilustrar as hibridações entre linhas de força que se confluem - em meados dos anos de 2000 - no âmbito das contestações desenvolvidas. É possível suspeitar dessa possibilidade de união entre questões antagônicas. Contestar com cordialidade pode significar apenas repor com nova roupagem questões já tradicionais, nas quais, 0 tom afetivo resguarda em suas teorizações, sobretudo, uma vontade de erguer-se como superador de uma conjuntura cultural/social ao enveredar nos seus interstícios. Até que ponto essas práticas artísticas contribuíram e contribuem para questionar de forma efetiva a hegemonia dominante? Como examinar as tentativas de avanços e as necessidades de recuo do simples desejo de fazer parte das discussões em voga? Como analisar tais questões sem descartar ou endossar completamente um conjunto de construções teóricas e discursos formulados nos grandes centros do capitalismo para tratar de ações e práticas desenvolvidas distantes desses contextos?

Em Vitória, no Espírito Santo, Cine Falcatrua, Coletivo Maruípe e Coletivo Entretantos, formados em 2004, são exemplos de grupos representativos deste período. Um exame na forma que esses grupos conduziram algumas de suas ações auxilia a pensar nas indagações lançadas acima. Longe do estabelecimento de marcos de primazia dos ideais globais em ações locais, pouco frutíferos em uma época na qual a disseminação de informação é quase instantânea e amplamente acessível, o exame das questões que nortearam as atividades desses coletivos contextualiza 0 debate sobre a viabilização da democracia no âmbito da arte em Vitória na primeira década do século XXI. É possível, portanto, identificar na oposição entre disciplinaridade e extradisciplinaridade, na relação com o sistema instituído, na confecção de editais, e na promoção de eventos indícios da tentativa de participação dos coletivos na reconfiguração do circuito artístico. Deve-se, todavia, esclarecer que as questões que

$8 \quad 0$ fluxo maior de coletivos no cenário brasileiro a partir dos anos de 2000 é apontado por diversos autores, entre os quais, Ricardo Rosas (2003) e Felipe Scovino (2010, p.14). Ver: ROSAS, Ricardo. Notas sobre o coletivismo artístico no Brasil. Trópico, 2003. Disponivel em: <http://p.php.uol.com.br/tropico/html/textos/2578,1.shl>. Acesso em: 10 out. 2015. SCOVINO, Felipe. Do que se trata um coletivo? In: REZENDE, Renato; SCOVINO, Felipe (Ed.). Coletivos. Rio de Janeiro: Circuito, 2010, p.14. 
serão levantadas não abarcam, nem poderiam, o conjunto das poéticas apresentadas nos eventos promovidos por esses coletivos. Além disso, os limites de atuação - impostos ou autoimpostos - que serão analisados, não são adversidades específicas desses grupos, constituindo tentativas (em maior ou menor medida) de descentralizar o circuito artístico e atualizar o repertório cultural vigente na cidade.

O Cine Falcatrua, conforme recordou o integrante do coletivo Gabriel Menotti (2015) ${ }^{9}$, teve início por uma combinação de questões circunstanciais. Por um lado, em protesto contra a decisão da Reitoria da Universidade Federal do Espírito Santo (UFES) de transformar em salas de aula 0 antigo teatro Metrópolis - que na década de 1970 serviu de espaço para a organização do movimento cineclubista no Estado - , os estudantes ocuparam o prédio no final do ano de 2003. Durante o período de ocupação, trocavam arquivos de filmes e aproveitavam a conexão mais veloz da universidade para baixar outros, além de realizarem reuniões para assisti-los nos computadores com monitores de quinze polegadas que traziam de suas casas. Por outro, com a chegada de equipamentos novos de projeção na universidade - utilizados, sobretudo para a exibição de slides digitais nas salas de aula —, alguns docentes e alunos do curso de Jornalismo, passaram a imaginar uma utilização diferenciada para esse aparato extraordinário: exibir filmes e promover debates sobre cinema. Acrescenta-se aos dois fatores acima, a disseminação de ferramentas digitais que davam acesso e autonomia a baixo custo como a popularização das redes ponto-a-ponto (p2p), em decorrência da ampliação da velocidade de conexão com a internet, e ao desenvolvimento de codecs de vídeo mais eficientes (MENOTTI, 2015, p.98) que possibilitavam o compartilhamento de arquivos de filmes.

Para que os estudantes utilizassem os equipamentos de projeção da universidade, as atividades de exibição dos filmes foram formalizadas ainda no primeiro semestre de 2004 como um projeto de extensão do Departamento de Comunicação Social da UFES. Entretanto, como afirmou o autor "[...] o planejamento e as sessões ficavam a cargo dos estudantes - um grupo formado por cerca de dez egressos dos cursos de Jornalismo, Artes e Psicologia" (MENOTTI, 2015, p.97). As primeiras sessões do Cine Falcatrua foram realizadas no local de ocupação, recebendo, assim, a denominação de Videoclube Digital Metrópolis ao ser registrado oficialmente na universidade como um projeto de extensão. Porém, a UFES fechou o espaço para reforma e o cineclube passou a ser nômade sendo "[...] obrigado a subsistir de forma completamente diferente" e tendo que "[...] procurar um novo lugar a cada semana, adaptando suas projeções às situações mais diversas" (MENOTTI, 2015, p.100).

\footnotetext{
9 MENOTTI, Gabriel. Cineclubes piratas: aparatos tradicionais com tecnologia imprópria. Famecos: mídia, cultura e tecnologia, v. 22, n. 3, p.96-109, jul 2015. Disponível em: <http://revistaseletronicas.pucrs.br/ojs/index.php/revistafamecos/article/download/20590/13264>. Acesso em: 20 mai. 2017.
} 
Advém, daí o nome Cine Falcatrua, "[...] um apelido que expunha a aparente desorganização do grupo" (MENOTTI, 2015, p.100). Não sem razão, na medida em que as atividades se intensificaram, o nome oficial foi sendo absorvido por sua alcunha. Se as primeiras exibições e outras ações do grupo, inicialmente ficaram restritas aos espaços da universidade, algumas vezes ao ar livre ${ }^{10}$, o caráter nômade foi intensificado e novas parcerias foram estabelecidas. Em setembro de 2004, por exemplo, anunciaram que a comunidade do morro de São Benedito ${ }^{11}$ seria a primeira a ser beneficiada com a assessoria do grupo na montagem de um cineclube próprio, intitulado de Cine Chocolate, que realizou sua primeira exibição no dia 19 do mesmo mês e ano. Desenvolveram ainda colaborações momentâneas com outros grupos locais, como o Antimofo, projeto dedicado à cena underground e à música alternativa ${ }^{12}$, o coletivo Maruípe ${ }^{13}$ e o coletivo Entretantos ${ }^{14}$. Em outubro de 2004, participaram do festival Digitofagia, no Museu da Imagem e do Som de São Paulo (MIS), realizando um debate, desenvolvendo uma oficina, trabalhando, ainda, de forma colaborativa com 0 coletivo neuroTransmitter ${ }^{15}$ de Nova York ${ }^{16}$ (Fig. 01). Em 21 de outubro, o coletivo postou em seu Fotolog sobre o trabalho: "[...] não deu muito certo; o projetor tava pifado e o gerador de energia não falava nossa língua. Mas ficou o registro do trabalho em conjunto [...]" (FALCATRUA, 2004).

10 Cabe ressaltar, entretanto, que as exibições ocorriam, na maioria das ocasiões, em auditórios da Universidade Federal do Espírito Santo (UFES), entre os quais, o do CEMUNI IV (Célula Modular Universitária), pertencente ao Centro de Artes.

11 A ocupação do bairro ocorreu no começo dos anos de 1960, com migrantes, principalmente de Minas Gerais e do sul da Bahia, que tinham se deslocado para o Espírito Santo, atraídos por possíveis empregos com o processo de industrialização em curso no Estado. As informações foram retiradas do site da Prefeitura Municipal de Vitória. Disponível em: <http://legado.vitoria.es.gov.br/regionais/bairros/regiao4/saobenedito.asp>. Acesso em: 10 nov. 2016.

12 Segundo consta no fotolog do grupo, o único objetivo do coletivo é ter um espaço para realizar festas de psytrance indoor em um local mais acessível que os usualmente utilizados por organizadores de rave, geralmente, em pontos distantes dos centros urbanos. Disponível em: <http://www.fotolog.com/antimofo/mosaic/>. Acesso em: 30 out. 2016.

13 Os três coletivos atuaram em conjunto no encerramento da exposição do Maruípe na Galeria Homero Massena, intitulada Intervenção no Edifício das Fundações, em 04 de novembro de 2004. O Cine Falcatrua realizou o Festival é Falcatrua, com projeção de vídeos de grupos midiartivistas de várias partes do país, no espaço externo da galeria, com intervenção sonora do coletivo Antimofo. O Festival é Falcatrua, segundo consta no fotolog do Cine Falcatrua, é um festival reduzido à sua essência: uma festa de abertura e outra de encerramento. Se a abertura foi na Galeria Homero Massena, 0 encerramento ocorreu no Clube Centenário, local em que o Antimofo promovia seus eventos.

$14 \quad \mathrm{Na}$ abertura do projeto de intervenção urbana, denominado de MultipliCIDADE, concebido pelo coletivo Entretantos, o Cine Falcatrua participou da noite de abertura, apresentando o CortaCurtas. Essa foi a primeira edição do projeto MultipliCIDADE, ocorrida entre 14 a 21 de agosto de 2006.

150 coletivo neuroTransmitter iniciou suas atividades em 2001, formado pela artista multimídia Angel Nevarez e por Valerie Tevere, docente da área de comunicação no College of Staten Island/CUNY. Disponível em: <http://archive.eyebeam.org/people/neurotransmitter>. Acesso em: 30 nov. 2016

$16 \quad$ Neste projeto em parceria, cabia ao Cine Falcatrua organizar uma sessão de cinema e ao outro grupo, a transmissão do áudio por meio de ondas de rádio. Entretanto, a ação - que seria realizada no cruzamento da Avenida Ipiranga com a Avenida São João, em São Paulo - acabou não se concretizando por problemas técnicos. 


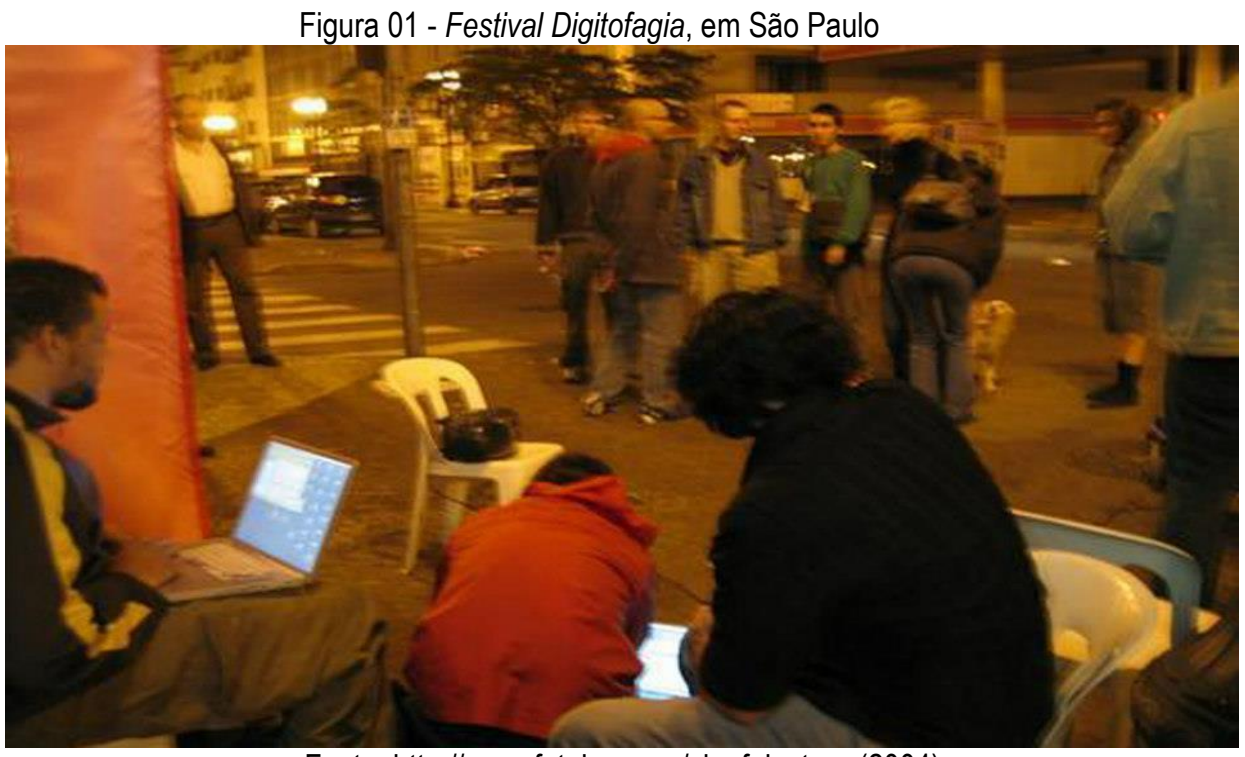

Fonte: http://www.fotolog.com/cinefalcatrua (2004).

Foi em 29 de julho de 2004, que as atividades do coletivo alcançaram repercussão nacional, desencadeadas por uma reportagem publicada no jornal Folha de S. Paulo, intitulada Universidade Federal em Vitória decreta "falcatrua" no cinema. Nesta, um dos entrevistados foi o representante da Associação de Defesa da Propriedade Intelectual (ADEPI) que classificou as atividades do coletivo como criminais. Assim:

Conforme essa notícia se espalhou pelo país, ela veio atrair a atenção de duas distribuidoras de filmes (Lumière e Europa Filmes) cujas obras haviam sido exibidas pelo cineclube. Menos de duas semanas depois, a universidade seria processada por essas empresas, além de receber uma queixa-crime movida pela ADEPI contra os participantes do projeto (MENOTTI, 2015, p.105).

Por sua vez, a constituição do Coletivo Maruípe, conforme pode ser apreendida de uma entrevista realizada em 2005, por Fernanda Albuquerque a Elaine Pinheiro, integrante do grupo, (ALBUQUERQUE, 2006, p.182-184) ${ }^{17}$, foi ocasionada pela necessidade de dividir os custos de manutenção do ateliê, localizado no bairro de Maruípe, em Vitória ${ }^{18}$. 0 espaço permitiria 0 desenvolvimento da produção dos seus integrantes, que além de estudantes de artes plásticas e arquitetura, também trabalhavam em instituições de arte ou eram "[...] ligados a estas e ao meio cultural

17 ALBUQUERQUE, Fernanda Carvalho de. Troca, soma de esforços, atitude crítica e proposição: uma reflexão sobre os coletivos de artistas no Brasil (1995 a 2005). Dissertação (Mestrado em Artes Visuais) - Universidade Federal do Rio Grande do Sul, Instituto de Artes, Porto Alegre, 2006.

$18 \quad O$ grupo, porém, permaneceu por pouco tempo no bairro que foi inicialmente instalado, tendo sido transferido para a região central da cidade, passando a funcionar na residência de um dos seus integrantes. Em outubro, o novo endereço é anunciado no blog do coletivo: "Frente a um turbilhão de acontecimentos, estudos e produções, ainda não fincamos definitivamente o pé no nosso espaço central, que é também residência do Fabrício Noronha (cine falcatrua) e do Sil (próprio maruípe)". Ressalta-se que a mudança ocorreu no período que o grupo estava realizando seu primeiro trabalho conjunto, a Intervenção no Edifício das Fundações, na Galeria Homero Massena, inaugurada em 21 de setembro e encerrada em 5 de novembro de 2004 (MARUÍPE, 2004). 
de alguma forma". Os encontros no ateliê, em reuniões semanais, desencadearam a ideia de desenvolver projetos conjuntos e promover um grupo de discussões "[...] que possibilitasse o estudo, a reflexão, a troca de experiências e, consequentemente, parcerias", para a execução das propostas (ALBUQUERQUE, 2006, p.182).

Em setembro de 2004, o Maruípe realizou a Intervenção no Edifício das Fundações, prédio localizado no Centro de Vitória cujo térreo abriga a Galeria Homero Massena. O trabalho em questão é uma espécie de ato inaugural das atividades do grupo, formado por Elaine Pinheiro, Meng Guimarães, Rafael Corrêa, Silfarlem Oliveira e Vinícius Gonzalez. A realização da intervenção foi decorrente do convite feito pela instituição para que o coletivo realizasse uma exposição ${ }^{19}$, entretanto, o grupo decidiu ampliar a proposta. Para tanto, resolveram utilizar também os outros espaços do prédio, que estavam sem uso naquele momento. 0 imóvel, pertencente ao governo estadual foi construído na década de 1970 e abrigou diversos órgãos públicos, entre os quais, os gabinetes dos deputados da Assembleia Legislativa do Espírito Santo e a sede da TV Educativa, porém, com a transferência de ambos para outros locais, o governo estadual destinou seu uso à Associação dos Funcionários Públicos do Espírito Santo (AFPES) que, "[...] alegando indisponibilidade financeira para realizar reformas [...] formalizou a devolução de posse do edifício ao Governo do Estado" (SANTOS, 2007, p.158)20, em setembro de 2003. Em 28 de setembro de 2004, o coletivo descreveu que desde sua primeira visita à Galeria eles decidiram tratar o edifício "como um único volume, englobando tanto a galeria quanto os andares do prédio [...] [sendo que] uma das propostas centrais é intervir na fachada do prédio" (MARUÍPE, 2004)21. No alto do edifício, os artistas inseriram a palavra "Vende" (Fig. 02) - que podia ser visualizada durante o dia -; no período noturno, projeções com imagens coletadas ao longo das inspeções, ocupavam a fachada; enquanto na parte interna da galeria foi realizada uma instalação com os destroços encontrados nos demais andares. 0 amontoado de entulhos (Fig. 03) - disposto na área central do espaço com iluminação controlada - destoava dos preceitos apregoados pelo coletivo. Segundo consta em texto jornalístico, publicado no dia da abertura da mostra, a pretensão era:

19 Conforme esclareceu Bernadette Rubim Teixeira, mencionando uma declaração atribuída à Teresa Giuberti — responsável pela coordenação da Galeria Homero Massena no período - a intervenção foi decorrente dos critérios estabelecidos, em 2003, para o calendário de exposições a ser realizado no ano seguinte, que seria voltado para jovens artistas provenientes do Centro de Artes da UFES (TEIXEIRA, 2009, p.146). TEIXEIRA, Bernadette Rubim. Galeria Homero Massena: interfaces entre políticas públicas estaduais e as artes visuais no Espírito Santo. Dissertação [Mestrado] Programa de Pós-graduação em Artes. Universidade Federal do Espírito Santo, Vitória, 2009.

$20 \quad$ Neste texto, Marcus Vinícius, integrante do coletivo Entretantos, também manifesta sua vontade de propor ações interventivas no Edifício das Fundações, afirmando que ao realizar seu mapeamento não pretendia produzir um objeto, mas propor a utilização do prédio para atividades individuais e coletivas, como, "encontros, palestras, publicações, exposições e conversas [...]" em "[...] um conjunto aberto e em expansão de ações e de olhares sobre esses $3,700,00 \mathrm{~m}^{2}$ na cidade de Vitória" (2007, p. 160). SANTOS, Marcus Vinícius de Souza. Mapeamento do Edifício das Fundações: uma construção estética e poética no espaço. In: Seminário Internacional de Pesquisadores do Processo de Criação. Vitória. Seminário Internacional de Pesquisadores do Processo de Criação, 2007.

21 Disponível em: <http://maruipe.zip.net/>. Acesso em: 24 set. 2016. 
[...] instigar o visitante (ou o passante) a refletir sobre essa fronteira da arte contemporânea, que mais e mais tende a não se restringir a quatro paredes de galerias, com ambientes climatizados e neutros.

O Edifício das Fundações, eles dizem, é só o primeiro passo. Os integrantes querem também discutir sobre outros pontos de Vitória sujeitos a essa intervenção (PEREIRA, $2004)^{22}$.

Entretanto, não havia consenso entre seus integrantes sobre a realização da instalação. Elaine Pinheiro postou no blog do grupo, a imagem da instalação em conjunto com frases de Allan Kaprow que colocavam em xeque esse tipo trabalho. Questionada por outro integrante, ela respondeu que antes de ser uma provocação, seu intuito era expor as referências que embasavam sua argumentação contrária à instalação, concluindo: "Continuo a fim de discutir sobre isso, inclusive com outros internautas e visitantes do maruípe" (PINHEIRO, 2004)23.

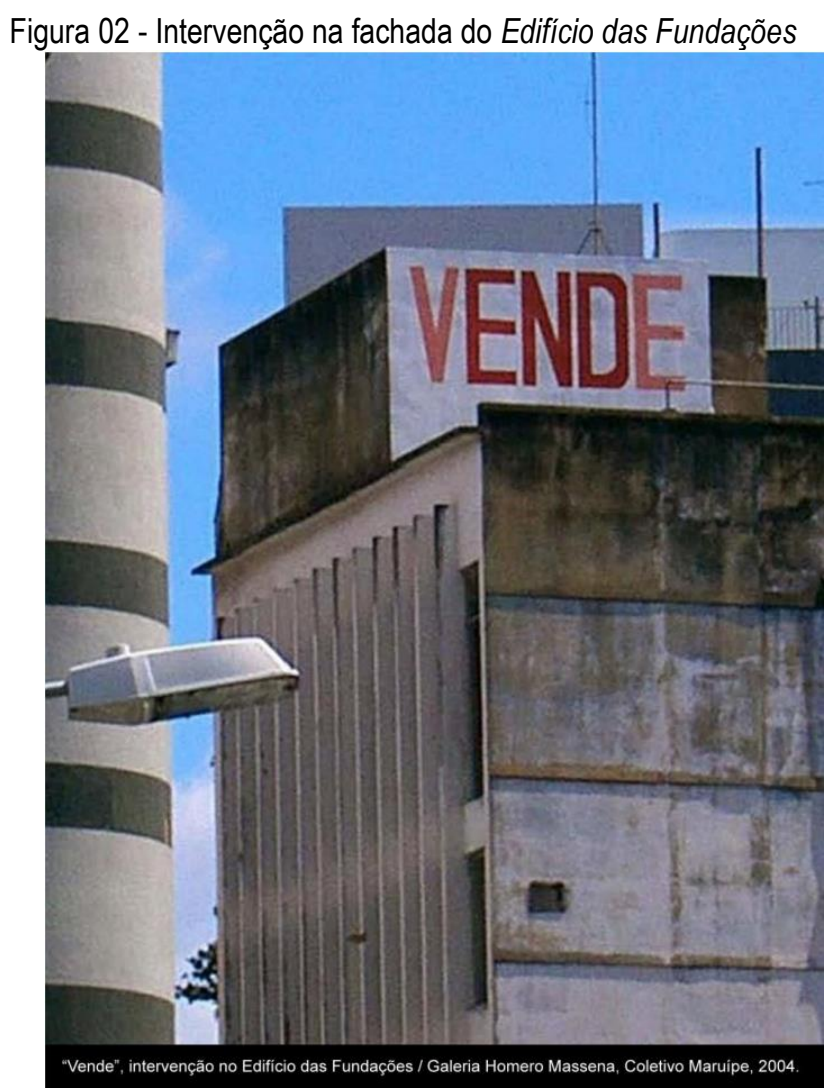

Fonte: http://maruipe.zip.net/ (2004).

22 PEREIRA, Marcelo. Obras "escapam" da galeria e invadem ruas da Cidade Alta. Vitória: A Gazeta, 21-09-2004. Recorte de jornal disponibilizado pelo Coletivo Maruípe no material de inscrição do $8^{\circ}$ Salão Bienal do Mar.

23 A postagem foi realizada em 27 de outubro de 2004. Dentre as frases mencionadas de Allan Kaprow, as últimas foram as que desencadearam o debate: "[...] a riqueza e a variedade de estados de consciência nas artes hoje (1969) são tão grandes que é difícil deixar de admitir os fatos seguintes: [...] que o pó sob as camas e os restos nos depósitos industriais são mais atraentes que as exposições (muito em moda hoje) de sucata espalhada". O questionamento foi do integrante Rafael Corrêa que indagou se seria uma provocação (CORRÊA - 30-10-2004), ao que ela responde: "o texto do Kaprow, antes de ser uma provocação, é uma das referências pro meu argumento de não transportar os entulhos dos andares pra galeria do edifício. Continuo a fim de discutir sobre isso, inclusive com outros internautas e visitantes do maruípe" (PINHEIRO- 30-10-2004). Disponível em: <http://maruipe.zip.net/>. Acesso em: 20 mai. 2017. 
Figura 03 - Instalação no interior da Galeria Homero Massena

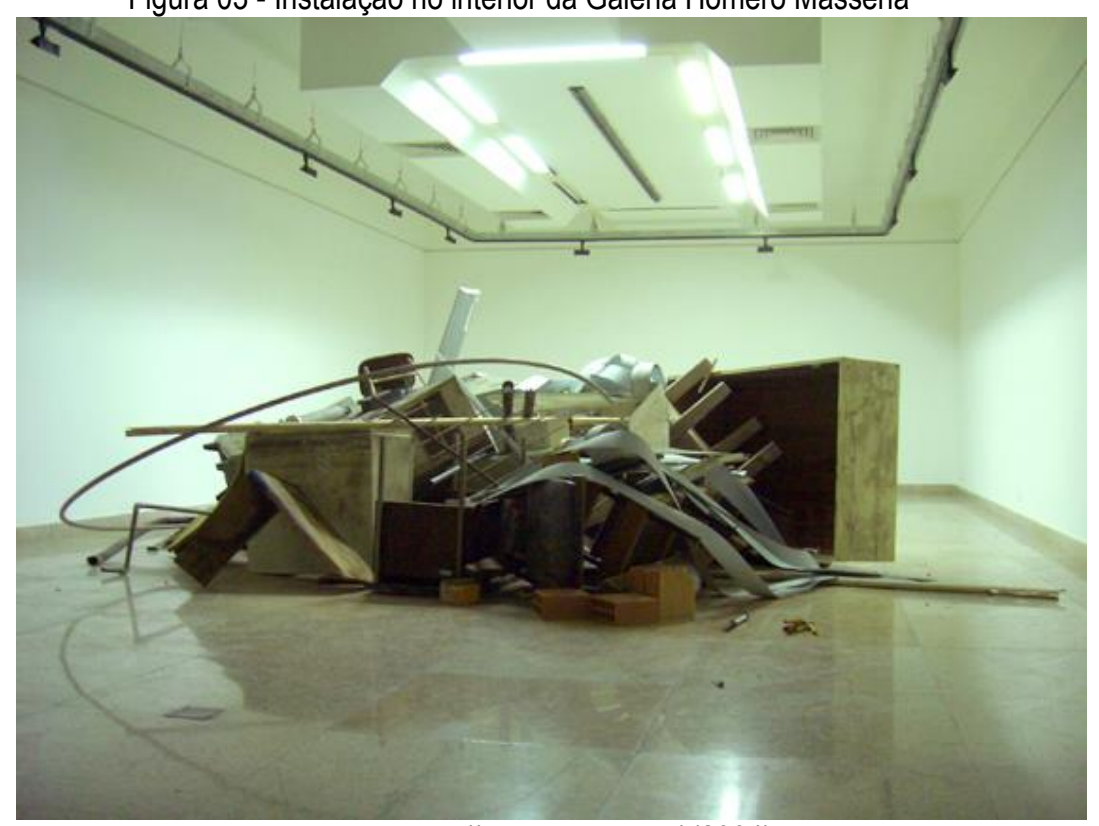

Fonte: http://maruipe.zip.net/ (2004).

Algumas questões que aparecem de forma embrionária nesse trabalho são desdobradas na ação seguinte do grupo, realizada no final desse mesmo ano. Conforme pode ser apreendido dos e-mails trocados entre os participantes, incluindo os próprios membros do Coletivo Maruípe, a informação que fariam o evento começou a circular em $1^{0}$ de dezembro, sendo que, a ação teria início no dia 16 do mesmo mês ${ }^{24}$. Trata-se do projeto, conduzido de forma independente pelo coletivo, denominado de Paralela-ao-Mar. O título foi tomado de empréstimo a duas diferentes mostras. Nas trilhas abertas pelo evento, iniciado naquele $\mathrm{ano}^{25}$, em realizar exposições de arte contemporânea brasileira em paralelo à Bienal Internacional de São Paulo, o coletivo apropriou-se do termo "paralela", estabelecendo um diálogo com o evento local VI Salão Capixaba do Mar, organizado pela Casa Porto das Artes Plásticas ${ }^{26}$. Porém, diversamente do evento oficial da Secretária Municipal de Cultura da Prefeitura de Vitória (SEMC/PMV), realizado dentro do espaço expositivo convencional, a intenção do grupo era "[...]

24 Tal afirmação considera o e-mail encaminhado por Elaine Pinheiro aos demais membros do grupo. Em $1^{\circ} \mathrm{de}$ dezembro de 2004, ela solicita maiores informações, visto não ter participado da última reunião do coletivo. "[...] recebi 0 convite do Rafael pra participar desse grupo, paralela ao mar. mas qual é?!! Gostaria de receber mais informações. Como foi a reunião ontem, e quais textos vcs estudaram?!! o q mais vcs conversaram?!! Por favor, atualizem-me." (PINHEIRO, 2004). Disponível em: <https://br.groups.yahoo.com/neo/groups/paralelaaomar/conversations/messages/2>. Acesso em: 02 jun. 2017.

25 Esta primeira Paralela, organizada por galerias de arte de São Paulo, foi curada por Moacir dos Anjos, a excelência do trabalho curatorial foi bastante destacada pela imprensa, tanto em textos do período quanto posteriores. Ver, por exemplo: CYPRIANO, Fabio. Conservadora e superficial, Paralela 10 tornou-se vítima do circuito que a criou. São Paulo: Folha de S. Paulo, 02-10-2010. Disponível em: <http://www1.folha.uol.com.br/fsp/ilustrad/fq0210201029.htm>. Acesso em: 25 set. 2016.

26 Trata-se do setor da Secretaria de Cultura da Prefeitura Municipal de Vitória (SEMC/PMV) responsável pelas ações de artes visuais do município. 
discutir questões relacionadas às práticas artísticas com a cidade [...]" (SILLFRALEY, 2004)27. Com 0 objetivo de debater as ações, produção e reflexões do evento Paralela-ao-Mar, o coletivo usou uma lista de discussão ${ }^{28}$ do yahoo ${ }^{29}$ como principal plataforma de franco acesso ao evento.

Por sua vez, o coletivo Entretantos, formado basicamente, pelos artistas e estudantes no Centro de Artes da UFES Marcus Vinícius, Rafael Massena e Renato Marianno ${ }^{30}$, concebeu e realizou o evento multipliCIDADE nos anos de 2006 e 2007, tendo como maior objetivo pensar o lugar da arte na cidade, além de inserir Vitória no circuito artístico independente. Segundo, consta no catálogo do projeto multipliCIDADE de 2006, o evento foi concebido depois de "[...] longas conversas e trocas de e-mails com organizadores e participantes de iniciativas como o Salão de m.a.i.o., em Salvador, o EIA Experiência Imersiva Ambiental, em São Paulo e o Spa das Artes, em Recife" (SANTOS; TEIXEIRA, 2006, p.15) ${ }^{31}$. Assim, se o evento Paralela-ao-mar do Maruípe foi realizado de forma impulsiva, diversamente, o multipliCIDADE foi planejado com antecedência e utilizou o know-how de iniciativas anteriores de grupos congêneres, fato que transparece tanto nas parcerias tecidas quanto na forma de organização e sistematização das etapas do projeto.

Nessas duas edições do evento, o grupo organizou ações artísticas em espaços públicos externos e internos, palestras, residências artísticas e oficinas. Os eventos contaram com o apoio da Secretaria de Cultura do Estado (SECULT) e da SEMC/PMV, por meio da utilização da galeria Homero Massena e da Casa Porto das Artes Plásticas ${ }^{32}$, bem como, da Secretaria de Produção e Difusão Cultural da UFES (SPDC) para a publicação dos textos sobre o multipliCIDADE em duas edições sob o

27 A frase mencionada consta no release que o Coletivo Maruípe enviou para a imprensa. Disponível em: <https://br.groups.yahoo.com/neo/groups/paralelaaomar/conversations/messages/50>. Acesso em: 09 mai. 2017.

$28 \quad$ Cabe esclarecer que nas citações dos escritos por correio eletrônico, optou-se por manter o texto original, sem a utilização do Sic, em razão de sua peculiaridade em relação à escrita epistolar. É justamente, nessas frases construídas com agilidade que pode ser detectada certa cor, informalidade e objetividade nos debates travados. Além disso, alguns autores já têm considerado esse tipo de texto como um novo gênero textual. Portanto, a utilização do Sic, apenas contribuiria para "poluir" ou dificultar a leitura. Cf: PAIVA, Vera Lúcia M. O. E-mail: um novo gênero textual. In: MARCUSCHI, L.A. \& XAVIER, A.C. (Orgs.). Hipertextos e gêneros digitais. Rio de Janeiro: Lucerna, 2004, p.68-90.

$29 \quad$ A lista está sob a url: http://br.groups.yahoo.com/group/paralelaaomar/.

30 Cabe ressaltar que, em 2007, o grupo é apresentado como constituído por seis integrantes, entre alunos e exalunos dos cursos de Artes Visuais, Artes Plásticas, Psicologia e Comunicação Social, porém, seus membros mais constantes foram os artistas Rafael Massena, Marcus Vinícius de Souza Santos e Renato Marianno Júnior [estes dois últimos faleceram precocemente em 2012]. Ressalta-se que, os três cursaram Artes na Universidade Federal do Espírito Santo (UFES). No currículo Lattes de Marcus Vinícius de Souza Santos, atualizado pela última vez em 29/05/2009, no item "Projetos em desenvolvimento", o autor, menciona o Entretantos como ainda atuante e apresenta seu nome como Coordenador. Disponivel em: <http://lattes.cnpq.br/9797455066788577>. Acesso em: 17 ago. 2016. A informação citada referente aos outros integrantes consta em página já não mais disponível, tendo sido acessada, em 26/04/2014, em levantamento preliminar para esta pesquisa. Seu link era: http://coletivoentretantos.multiply.com/

31 SANTOS, M. V. S.; TEIXEIRA, B. R. multipliCIDADE: projeto de ações e intervenções urbanas. Vitória: Produção Independente, 2006.

32 Uma das ações do Coletivo Entretantos, dentro da programação do evento multipliCIDADE 2007, foi a exposição Dedo de Moça, coletiva curada por Marcus Vinícius que, reuniu obras de vinte artistas do sexo feminino, na Casa Porto das Artes Plásticas, entre 05 e 14/11/2007. 
título multiplicidade: projeto de ações e intervenções urbanas. Além disso, o coletivo expôs os registros do evento no seu blog ${ }^{33}$ e, na exposição na galeria Virginia Tamanini, localizada no Centro de Vitória (Fig. 04). O multipliCIDADE é apresentado como um projeto de ação/intervenção urbana que:

[...] pretende que a cidade de Vitória se apresente como uma plataforma de interação entre a arte contemporânea e as pessoas que nela habitam, num campo de experiência, de trajeto (casual ou intencional) e de olhar. Uma relação estabelecida à escala individual, num contexto social, em que o público fica de imediato integrado num espaço de exposição de características singulares. A cidade, o cotidiano, a arte e o indivíduo abertos a todos os imaginários, num processo contínuo, acessivel e abrangente de comunicação (SANTOS; TEIXEIRA, 2006, p.05, grifos dos autores).

Figura 04 - Montagem da exposição dos registros do multipliCIDADE - Galeria Virginia Tamanini, 19 até 21/11/2006
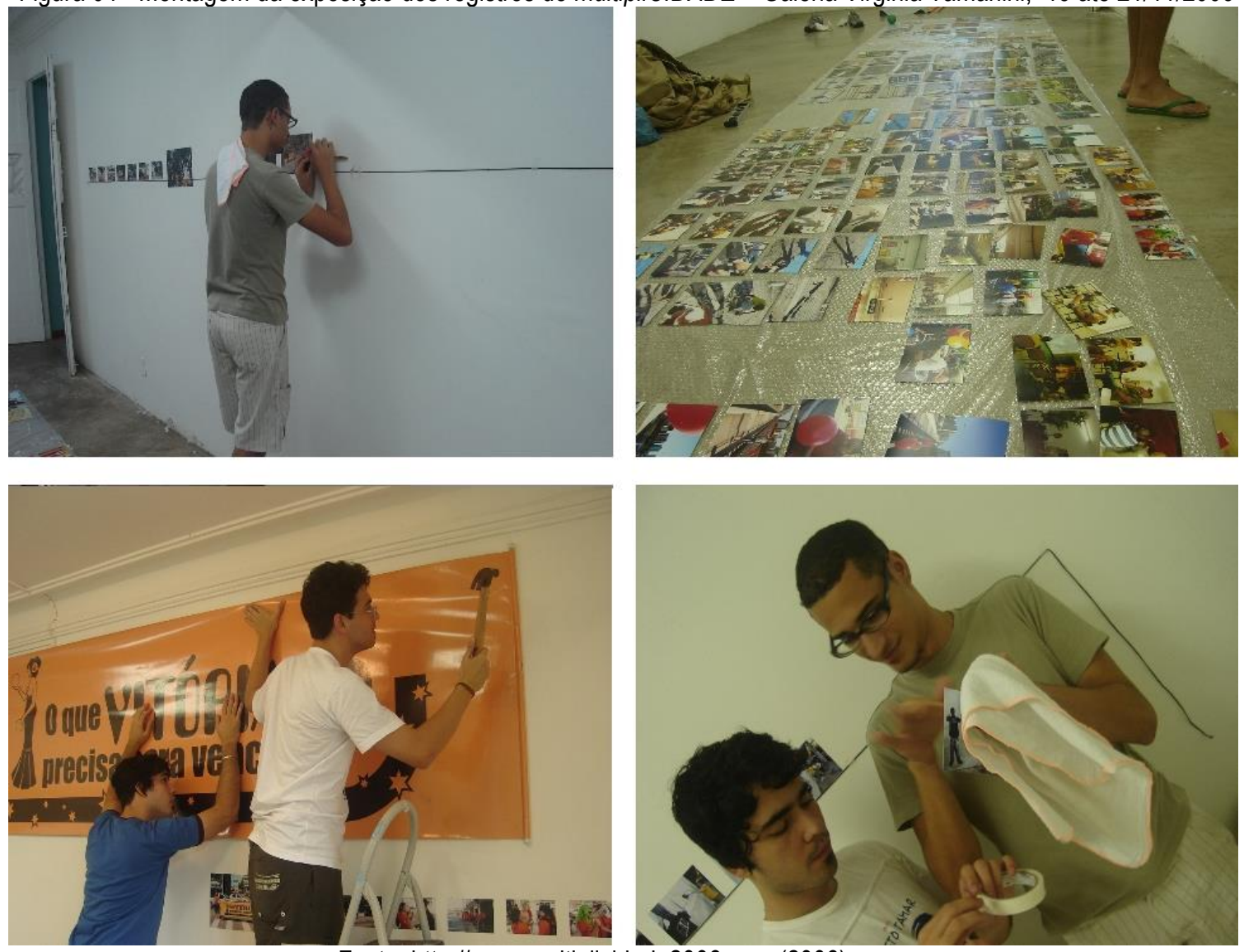

Fonte: http://www.multiplicidade2006.com (2006).

A participação, colaboração, organização, idealização e formulação dos eventos do coletivo Entretantos seguiu, todavia, política diferenciada do coletivo Maruípe e do Cine Falcatrua. Ainda que de forma distinta, uma questão comum aos três coletivos, como tantos outros exemplos do período, foi a importância conferida à ideia de participação e colaboração, tanto entre os integrantes dos coletivos com demais artistas e/ou colaboradores quanto em relação ao público em um sentido mais amplo. 


\subsection{PARTICIPAÇÃO/COLABORAÇÃO: DISCIPLINARIDADE E EXTRADISCIPLINARIDADE}

Considerando o crescimento das práticas participativas nas últimas décadas, Alexander Alberro, no texto Periodising Contemporary Art (2011) ${ }^{34}$, realiza uma síntese e destaca as principais causas que desencadearam uma mudança sísmica e que juntas resultaram no realinhamento do campo das artes em um período que passou a ser denominado simplesmente como contemporâneo ${ }^{35}$. O ano de 1989 é adotado como referência, evidentemente, pela queda do muro de Berlim, o colapso da antiga União Soviética e a "proclamação da era da globalização", aliados à "integração da cultura digital" e à "hegemonia do neoliberalismo econômico", fatores que são sublinhados para assinalar que nas artes o realinhamento citado teve como desdobramento uma alteração na relação com a figura do espectador ou, nas palavras do autor, "na maneira que a arte trata seu espectador" (ALBERRO, 2011). Tal questão é ponderada por Claire Bishop. Para ela, a noção de público - definido anteriormente como espectador - que passou a ser reposicionada na atualidade como coprodutor ou participante é mais potente como ideia do que como realidade, porém, de qualquer forma, a autora entende que a questão é intrínseca às tentativas de pressionar os modos convencionais de produção e consumo artístico sob o capitalismo (BISHOP, 2012, p.3) ${ }^{36}$.

Analisando a expansão das práticas participativas, considerando especialmente 0 contexto europeu e norte-americano, Claire Bishop afirmou que, no começo da década de 1990, a produção de cunho participativo e fortemente marcada por interesse pelo social estava confinada à periferia do mundo da arte. A autora apontava para o seu perfil relativamente fraco no circuito artístico comercial, relacionando 0 aumento crescente dessas práticas à expansão sem precedentes das bienais. Teriam sido "[...] estabelecidas 33 novas bienais, só nos últimos 10 anos, a maioria em países até recentemente considerados periféricos ao mundo da arte internacional" (BISHOP, 2008, p. 146) ${ }^{37}$. Outro fator estaria atrelado ao aumento do "novo modelo de agências gerenciadoras de encomendas, dedicadas à produção de arte experimental comprometida com o domínio público (Artangel em Londres, Skor na Holanda e a Nouveau Commanditaires na França...)" (BISHOP, 2008, p.146).

\footnotetext{
34 ALBERRO, Alexander. Periodising Contemporary Art (2011). Disponível em: <http://www.globalartmuseum.de/site/guest_author/306>. Acesso: 19 abr. 2014.

35 As tentativas de redefinir a abrangência do termo contemporaneidade dentro da História da Arte se proliferaram, sobretudo, a partir de 2009. Normalmente, os autores passaram a adotar o ano de 1989 como marco. Dentre os inúmeros esforços teóricos, cabe destacar a contribuição de Terry Smith $(2010 ; 2013)$ que localizou nos novos arranjos ocasionados pelas alterações em larga escala que reconfiguraram a arte recente, imprimindo alterações na dinâmica dos espaços culturais, no mercado da arte e na carreira dos artistas, sinais de que a arte contemporânea tornou-se um campo dentro da disciplina História da Arte. Ver: SMITH, Terry. "Our" Contemporaneity? In: DUMBADZE, Alexander and HUDSON, Suzanne (Ed.). Contemporary art: 1989 to the present. John Wiley \& Sons, Inc., 2013; SMITH, Terry. The State of Art History: Contemporary Art. Art Bulletin. Vol. XCII, n. 4 (December 2010, p.366-383).

36 BISHOP, Claire. Artificial Hells: Participatory Art and the Politics of Spectatorship. New York: Verso, 2012.

$37 \quad O$ artigo foi publicado originalmente em 2006, na Artforum. BISHOP, Claire. A virada do social e seus desgostos.

In: Concinnitas. N 12, Vol. 01, ano 09, Julho, 2008.
} 
Todavia, mais recentemente, a situação foi invertida, tornando-se "um gênero em seu direito próprio, com cursos de mestrado (MFA - Master of Fine Arts) em prática social e dois prêmios específicos" (BISHOP, 2012, p.2) ${ }^{38}$. A revisão, portanto, desta perspectiva identificou a presença significativa da produção artística de caráter social dentro de escolas de arte, museus e mesmo em galerias comerciais (BISHOP, 2012, p.18), o que revela a estabilização dessas práticas, sua institucionalização.

Se na atualidade, conforme identificou a autora, parte dessa produção foi sendo absorvida pelo sistema, nos seus anos iniciais, vagou entre uma estrutura institucional assentada que dava sinais de obsolescência e as questões novas e prementes que estavam entrando em pauta. Independentemente da localização geográfica, para Claire Bishop, a característica marcante dessa nova orientação artística voltada para o social pode ser observada a partir de um desejo compartilhado de desmantelar a relação tradicional entre o objeto de arte, o artista e o público. Assim, a figura do artista, como produtor individual de objetos, foi embaçada pela noção do artista como colaborador e gerador de situações, enquanto a obra de produto portátil e comercializável foi repensada como projeto em andamento (com começo e fim, em muitas ocasiões, indeterminados) e o público - anteriormente compreendido como espectador - passou a ser reposicionado como coprodutor ou participante (BISHOP, 2012, p.2).

As ações desenvolvidas pelos coletivos capixabas, Cine Falcatrua, Entretantos e Maruípe servem para exemplificar esse período de transição, evidenciando a nova posição assumida pelos artistas diante de um quadro de mudanças, no qual, enquanto um sistema se dilacerava, outro emergia, e ambos procuravam se reinventar frente ao que Roger Chartier sintetizou como um período marcado por "uma modernidade que se desfaz, talvez, diante de nossos olhos" (CHARTIER, 2010, p.7).

Em $2002^{39}$, quando a expansão dessas iniciativas ainda estava em processo incipiente de análise ${ }^{40}$, especialmente no contexto brasileiro ${ }^{41}$, Agnaldo Farias (2006a) traçou um perfil do campo

$38 \quad$ Em nota, a autora lista programas como o Art and Social Practice na Portland State University e na California College of the Arts, o Public Practice na Otis College of Art and Design, e o Contextual Practice na Carnegie Mellon University, Pittsburgh, bem como os prêmios Leonore Annenberg Prize para Art and Social Change, em Nova York, iniciado em 2009, e o International Prize for Participatory Art, na Itália, inaugurado em 2011 (BISHOP, 2012, p.287).

$39 \quad$ O texto foi originalmente publicado em 2002, porém, publicado novamente em 2006 (FARIAS, 2006, p.525-529).

$40 \quad$ No que tange as análises sobre as alterações no campo da arte nesse período, incluindo a questão participativa na arte contemporânea, a publicação do livro Estética Relacional de Nicolas Bourriaud, na França em 1998, foi um marco. Entretanto, apenas após a tradução para a língua inglesa, em 2002, foi que o livro alcançou repercussão nos debates críticos, mais precisamente a partir de 2004. Neste ano, Claire Bishop publica o artigo Antagonismo e Estética Relacional na Revista October, Grant Kester dedicará respostas críticas ao texto de Bourriaud em Conversation Pieces (KESTER, 2004) e Julian Stallabrass em Art incorporated (STALLABRASS, 2004). Ainda que os autores, quase sempre, mencionem 0 pioneirismo de Bourriaud, não deixam também de tecer ácidas críticas a sua abordagem. Portanto, a tese de que o debate sobre a questão participativa na arte contemporânea ainda estava em processo inicial de análise, especialmente no Brasil, procede. Aqui, apesar de alguns textos seminais terem sido publicados em revistas especializadas, Estética Relacional só recebeu tradução para o português em 2009. 
artístico brasileiro, apontando para o descompasso entre o desenho do circuito artístico instituído e as investigações mais experimentais em curso. Segundo o autor, com escassas exceções, a expressão contemporânea não estava sendo beneficiada em uma época que o Brasil entrava na era dos espetáculos. Para Farias, o crescimento de exposições de grande porte - algumas de caráter duvidoso, porém, chanceladas por museus de referência, como o MASP42 - e a continuidade dos salões de arte como locais de legitimação assinalam parte do quadro formado pelo circuito instituído, contra o qual, tendências experimentais surgem procurando criar novas redes de significação. Em 2006, o autor retoma sua análise anterior e associa a expansão dos coletivos na cena artística brasileira, "[...] que balizam suas ações por investidas contra ou simplesmente fora das instituições", sobretudo, ao que denominou de "[...] uma estratégia de sobrevivência da arte diante da política de espetacularização que no Brasil adquire dimensões cada vez maiores" (FARIAS, 2006b, p.241, grifo meu).

É do embate entre artistas e instituições da arte, em um quadro que incluía tanto a manutenção, expansão e a reformulação do formato dos salões - já há muito tempo considerados anacrônicos - quanto à intensificação das intervenções urbanas, que a questão participativa emerge, com vigor, nesse período, entre os artistas brasileiros. Ricardo Rosas (2006) apontou, dentre os elementos que desencadearam a formação desses coletivos, a realização de festivais ${ }^{43}$, mostras e encontros, durante os quais os artistas se aproximavam e formavam uma rede de contatos, facilitada pela troca de e-mails. Ainda segundo o autor, eles buscavam alternativas de interação com os espaços da cidade, oferecendo "[...] espontaneidade, diálogo com o local, quebra do protocolo 'sério' da arte convencional, participação do público, temporalidade volátil, ênfase nas sensações e interpretação [...]" (ROSAS, 2006, p.296). Questões que faltavam, para Ricardo Rosas, "[...] na dita 'arte pública'”, assim, dentro de um contexto que tensiona "os parâmetros que regem a vida urbana" os artistas transgrediam "códigos de urbanidade, relações usuais com o espaço urbano, clichês comportamentais, introduzindo igualmente ações e interferências absurdas ou surreais" (ROSAS, 2006, p.296).

Se os coletivos Maruípe e Entretantos podem ser perfeitamente pensados a partir do quadro esboçado acima por Ricardo Rosas, a trajetória e o posicionamento do Cine Falcatrua diante da

$41 \quad$ Entre os trabalhos pioneiros no contexto acadêmico ou do circuito oficial de arte estão: (OSÓRIO, 2001 e 2006), (CESAR, 2002) e (COCCHIARELE, 2003). OSORIO, Luiz Camillo. Um panorama e algumas estratégias (2001). In: FERREIRA, Gloria. Crítica de arte no Brasil: temáticas contemporâneas, 2006, p.509-512.

$42 \quad$ Na época, o MASP estava sob a direção do arquiteto Júlio José Franco Neves, que permaneceu como seu presidente por quatorze anos, entre 1994 até 2008. A administração do museu por Júlio Neves foi muito criticada: suas ações ruidosas e insólitas foram associadas aos abalos no prestígio do MASP.

43 O autor destacou o prêmio "Interferências Urbanas" (Rio de Janeiro) e o encontro "Perdido no Espaço" (Porto Alegre), ambos tiveram início em 2000. 
disciplina artística são diferenciados. Tanto sua gênese, situada no movimento contra uma decisão institucional em desmontar o teatro Metrópolis, quanto à sua continuação, com a filiação institucional por meio do projeto de extensão universitária, revelam a transversalidade que pautou a ação do coletivo majoritariamente até a oficialização como grupo artístico por meio da entrada no projeto Rumos do Itaú Cultural (2005-2006), quando o Cine Falcatrua se assume como artístico. Até então, a ação do grupo estava circunscrita essencialmente como movimento, na qual, mobilização e o serviço consistiam no meio de produção primordial. Queixa e atitude, portanto, diante da precariedade dos dispositivos culturais instituídos em Vitória, constituem aquilo que a disciplina poderia chamar de obra.

A composição do grupo por estudantes de cursos diversos ${ }^{44}$, cuja "[...] única particularidade notável é que não incluísse ninguém ligado à produção, estudo ou crítica do audiovisual" (MENOTTI, 2015, p.97-98), impulsionou o desenvolvimento de ações combinatórias, situadas nos entremeios entre áreas. Fica clara a tendência de afastar as ações do grupo de ditames disciplinares, acadêmico ou qualquer outra apropriação séria por meio da ausência - não a proibição - de participantes vinculados de alguma forma ao circuito audiovisual. Esta postura anticlassista, despojada dos narcisismos e questões monotemáticas de agrupamentos com causas específicas, centrava-se na grande questão de quem vivenciou o início do século XXI, não apenas em países periféricos, mas, sobretudo neles: 0 acesso. A internet, mesmo na precariedade das redes dialup e banda larga com baixa velocidade, ampliou àqueles que a utilizava a dimensão do que thes estava sendo negado. Para um grupo heterogêneo de jovens, mais importante do que elevados debates teóricos ou disseminação de determinada estética artística era o acesso à cultura de seu tempo. Esta cultura não englobava apenas os filmes da temporada, nem os games caríssimos que poderiam ser emulados no computador, ou os álbuns inteiros que poderiam ser baixados daquela banda pop que não era vendida nas lojas do ramo da cidade, mas a possibilidade de experimentar com autonomia. É neste sentido que tanto o conhecimento dos procedimentos de captura quanto de execução constituíam o cerne de quem detectou na internet uma possibilidade de sair dos ditames culturais impostos até então, seja pela indústria cultural de massa ou por aquela chamada de cultura erudita.

$44 \quad$ Inicialmente, até meados de 2004, o grupo era "formado por cerca de dez egressos dos cursos de Jornalismo, Artes e Psicologia", entretanto, é "impossível ser preciso a esse respeito porque o número de participantes flutuava muito. Como numa típica atividade grassroots, a divisão de papéis entre os organizadores e a audiência era fluida; não raro, pessoas completamente alheias ao grupo central traziam filmes para a exibição e ajudavam a montar os equipamentos" (MENOTTI, 2015, p.97). Entre 2005 e 2006, entretanto, os integrantes do grupo, segundo consta no catálogo do projeto Rumos (2006, p.324), eram: Gabriel Menotti M. P. Gonring (Vitória/ES - 1983), Fabrício Noronha Fernandes (Vila Velha/ES - 1984), Rafael Trindade dos Santos (Vila Velha/ES - 1979), Gilbertinho Cineasta (Serra/ES - 1986), Frederico Roseiro (Vila Velha/ES - 1977), Fernanda Neves (Vitória/ES - 1983), Luiza Ricão (Vitória/ES - 1984) e Rodrigo Melo (Vila Velha/ES -1984). 
Além de questões trazidas por integrantes de universos diversificados, os meios e metodologias utilizados não eram exatamente comuns à disciplina artística. Essencialmente, a utilização de programas de download $p 2 p^{45}$, codecs de vídeo, emuladores de videogames ${ }^{46}$, armazenamento ${ }^{47}$, traduções e legendas, bem como o manuseio dos equipamentos de som, projetor e computador. $O$ estranhamento inicial causado pelo fato de ser um cineclube nômade é capaz de remeter o espectador aos tempos heroicos quando os artistas, em trupes ou caravanas circenses coloriam com entretenimento um recanto qualquer apartado do acesso à produção do seu tempo. É preciso recordar que, em 2004, o franco acesso às produções culturais era precário, quando comerciais, e raro, quando oriundos do circuito "alternativo", não apenas em instituições culturais, mas também via internet, uma vez que a obtenção de equipamentos, conexão e mesmo know how não estavam inteiramente disseminados - aliás, o conhecimento das operações necessárias para obter os conteúdos na web ainda hoje não é comum aos usuários ordinários ${ }^{48}$-, portanto, 0 trânsito, embora causado pela falta de espaço próprio, possibilitava a disseminação das ações do grupo para um público heterogêneo, não restrito apenas àqueles detentores dos bens simbólicos disciplinares. $O$ uso de uma metodologia itinerante, semelhante àquelas das companhias de teatro ou circo tradicionais, é representativa dessa fase de transição entre os agrupamentos físicos e os agrupamentos virtuais por meio de fóruns, listas de discussões, redes sociais, e pode ser justificada pela carência de equipamentos, conexão e know how. Embora se possa argumentar que o encontro é inalienável nos agrupamentos, uma nova ética é visualizável quando o acesso aos equipamentos, conexão e know how se torna possível. 0 crescimento de redes de relacionamento como Orkut e Facebook, ou mesmo de comunidades de serviços de jogos, animes, pornografia e cinema, subsistem sem qualquer tipo de encontro presencial.

O caráter eminentemente prático dessas ações em contraposição ao aspecto discursivo, reflexivo, ou retórico, que foi sendo incorporado aos trabalhos posteriores, é notável na fase inicial, completamente extradisciplinar, do coletivo. Com questões claras e objetivas, e metodologia padrão, a

45 Peer-to-peer, "par-a-par", ou "ponto-a-ponto" é um tipo de rede onde cada ponto é cliente e servidor ao mesmo tempo, onde o compartilhamento acontece sem a necessidade de um servidor central. Alguns programas comuns à época de atividade do Cine Falcatrua, por volta de 2004, são o Kazaa, Shareaza, Emule, Bittorrent, e Napster.

${ }_{46} \quad$ Um emulador de videogame é um programa que funciona como determinada plataforma lançada como aparelho físico capaz de rodar os jogos físicos convertidos em arquivos denominados roms. À época das atividades do grupo, ZSnes, Snes9X para SuperNintendo e ePSXe e pSX para PlayStation.

$47 \quad$ Gravadores de CD e DVD estavam se disseminando no Brasil, mas ainda constituíam uma possibilidade onerosa pelo valor do aparelho gravador e das mídias.

${ }_{48} \quad$ Poder-se-ia falar em analfabetismo digital funcional generalizado, uma vez que a digitação de uma busca no Google, criação de contas em redes sociais ou composição de um memorando no Microsoft Word não contam como conhecimento mínimo das potencialidades do equipamento computacional. Pelo contrário, atestam o controle total das corporações sobre a máquina do usuário. Sobre analfabetismo digital funcional, dentre outros, ver: OLIVEIRA, Carlos Alberto; DE AZEVEDO, Suami Paula. Analfabetismo digital funcional: perpetuação de relações de dominação? Revista Brasileira de Linguística, v. 15, n. 2, p.101-112, 2007. 
produção das ações girava em torno de tarefas: downloading de vídeos, conversão de arquivos, edição de legendas, transporte e montagem de equipamentos. O referencial teórico, certamente existia, mas diferentemente de ações internas à disciplina, não carecia de explicitações contínuas por conta de sua natureza secundária diante da premência em realizar as exibições.

Por outro caminho, em sua gênese, integrantes, temas e condutas, os coletivos Maruípe e Entretantos demonstravam preocupação no diálogo e inserção constante tanto no circuito quanto na disciplina artística. Ambos têm sua origem na necessidade de obtenção de espaço adequado para viabilizar sua produção artística própria, seja como grupo ou de forma individual. Porém, é a formação acadêmica de seus integrantes que permeará a conduta disciplinar desses grupos, essa formação levou a união, mobilizou a mão-de-obra e o engajamento necessário para a produção de seus próprios trabalhos e eventos. 0 Maruípe ${ }^{49}$ e o Entretantos ${ }^{50}$ eram compostos essencialmente por estudantes provenientes da área de artes e buscavam, em especial, discutir questões próprias do campo. Até mesmo as realizações das atividades ofertadas por esses grupos estão dentro do âmbito do circuito artístico. Oficinas, palestras, produção de eventos, exposições, fazem parte de um ambiente já estabelecido da disciplina. 0 espaço do ateliê, tão caro ao sistema artístico apoiado na noção de produção de objetos, que foi sendo reposicionado nas práticas que têm sido denominadas de pósateliê, bem como, o constructo de suas atividades a partir de um corpus de referência tecido por meio de discussões alicerçadas em textos da área e da experiência de outros artistas ${ }^{51}$ - já mencionadas em relação ao Maruípe -, também podem ser detectados no coletivo Entretantos. Em 2004, o grupo iniciou suas atividades no Atelier A5 que ficaram restritas até 2005 à participação em debates e discussões, uma ação artística de "Deriva Urbana", no Ipiranga, em São Paulo e uma exposição52. Cabe esclarecer, porém, que individualmente ao longo desse período seus membros realizaram outros trabalhos 53 .

\footnotetext{
49 O Maruípe desde seu momento inicial (2004) até sua dissolução, aproximadamente em 2009, manteve os mesmos integrantes: Elaine Pinheiro, Meng Guimarães, Rafael Corrêa, Silfarlem Oliveira e Vinícius Gonzalez. Todos os membros, no período de sua formação, eram estudantes de artes plásticas ou do curso de Arquitetura da UFES (ALBUQUERQUE, 2006, p.182).

$50 \quad$ Em relação aos integrantes do Coletivo Entretantos, ver nota 24.

51 Em 12 de outubro de 2004, por exemplo, o Coletivo Maruípe menciona em uma publicação do grupo: "[...] convidamos o artista plástico carlito carvalhosa (sp/ rj), q está na cidade por conta da exposição "casa - poética do espaço na arte contemporânea", para trocar uma idéia com a gente. o papo foi ótimo [...] nem tivemos tempo de convidar mais pessoas, pois td rolou meio em cima da hora. mas certamente irão acontecer mais desses encontros, com outras pessoas. estamos alinhavando um grupo de estudo de textos de arte contemporânea em inglês [...]". Disponível em: $<$ http://maruipe.zip.net/>. Acesso em: 10 dez. 2016.

52 A mostra foi denominada de Exposição Entretantos, tendo ocorrido na Faculdade Univila, na cidade de Vila Velha (ES), em 2004.

53 Marcus Vinícius, por exemplo, enviou como proposta ao evento Paralela-ao-Mar do coletivo Maruípe, a intervenção Algumas coisas você nunca vai saber pela mídia, na qual, pretendia espalhar por Vitória cartazes em preto e
} 
Foi com a intenção de ratear entre seus integrantes os custos de manutenção de um espaço que 0 coletivo Maruípe teve início. Em entrevista concedida à Fernanda Albuquerque (ALBUQUERQUE, 2006), Elaine Pinheiro, integrante do Maruípe, afirmou que:

O grupo surgiu em 2004, derivado de algumas pessoas que dividiam um atelier. A necessidade principal era dividir o aluguel desse espaço, o último andar de um sobrado em Maruípe, um dos bairros mais antigos de Vitória. Todos os integrantes do coletivo se conheceram através da faculdade, estágios ou trabalho. Somos estudantes de artes plásticas e arquitetura na Universidade Federal. Também trabalhamos em instituições de arte, ou estamos ligados a estas e ao meio cultural de alguma forma. Estávamos interessados num espaço em que pudéssemos produzir, ou mesmo guardar nosso material (ALBUQUERQUE, 2006, p.182).

Nascidos dentro da disciplina artística, tanto o Maruípe e quanto o Entretantos tentaram congregar ação e reflexão em suas atividades, seja pelo debate presencial e mostra dos registros em lista de discussão, como no caso do primeiro grupo, ou pela publicação e posterior exposição, no caso do segundo, o que se fala ou se mostra do fato tem tanta ou mais importância do que o fato em si. Para esses dois coletivos, o desenvolvimento de trabalhos práticos e a tentativa de acompanhar os debates e ações em curso no contexto artístico brasileiro eram complementares desde sua gênese.

Uma análise das características gerais dos três coletivos revela diferenças sutis, embora fundamentais no jogo da autoridade disciplinar. Movimento social e confecção de obras, serviço de conscientização sobre acesso à informação e palestras artísticas, além de suporte mútuo revelam questões de intencionalidade no âmbito das investigações e dos limites disciplinares.

O Cine Falcatrua a priori, não tinha qualquer intenção de estar circunscrito dentro da disciplina artística. Sua gradativa institucionalização, primeiro enquanto projeto de extensão, decorrente da necessidade de aparelhamento e, posteriormente de proteção contra os ataques processuais intuídos, mas provavelmente não previstos quando da institucionalização -, e, posteriormente, como projeto no Rumos do Itaú Cultural, já sob a guarida da aura artística, demonstram o caminho de fora para dentro do caráter disciplinar da arte. Assim, seus membros desenvolveram suas ações iniciais mais próximas ao que Brian Holmes (HOLMES, 2008), denominou de investigações extradisciplinares ${ }^{54}$

branco com tamanho $\mathrm{A} 3$, em meio aos anúncios publicitários com a frase que intitulava o seu projeto. A proposta do artista consta no blogger do Coletivo Maruípe. Disponível em: <http://www.maruipe.blogger.com.br/>. Acesso em: 10 dez. 2016.

54 De forma resumida e utilizando as próprias palavras de Brian Holmes, o conceito de investigações extradisciplinares "[...] foi criado como tentativa de superar um tipo de dupla falta de propósito que afeta as práticas de significação contemporânea, até mesmo como tentativa de fazer duplo desvio ainda que sem as qualidades revolucionárias que os situacionistas buscavam". O conceito procura ser "[...] um novo ponto de partida para o que costumava ser chamado de crítica institucional". Sua ambição "consiste em levar a cabo investigações rigorosas em áreas tão distantes da arte quanto finanças, biotecnologia, urbanismo, psiquiatria, o espectro eletromagnético, etc.". Produzindo "o livre jogo das faculdades e a experimentação intersubjetiva [...]", mas também procura "identificar nesses domínios os usos instrumentais ou espetaculares que tão frequentemente se fazem da liberdade subversiva do jogo estético" (HOLMES, 2008, p.8-9). 
em uma "[...] nova espécie de reflexibilidade [...] na passagem para além dos limites tradicionalmente atribuídos ao seu exercício" (HOLMES, 2008, p.8), desenvolvendo projetos que "[...] não podem mais ser definidos como arte sem ambiguidades" (HOLMES, 2008, p.11).

Esse exercício extradisciplinar foi também parcialmente adotado no Maruípe e Entretantos, embora sob uma intencionalidade completamente diversa. Do ponto de vista interno da disciplina, as intervenções no espaço urbano com a utilização de panfletos, peixes estragados, doces etc. — que um dia foi estranho ao ambiente artístico instituído, mas já não mais o era -, para a apresentação de obras com título e autor certos, configura o contrário do processo percorrido pelo Cine Falcatrua: um percurso de dentro para fora no qual a instrumentalização é a dos aspectos estranhos à disciplina. Como materiais para a confecção das obras são manobrados, portanto, uma miríade de recursos não convencionais que, por mais variados, chocantes, exóticos, raros, ou inusitados que possam parecer, são incapazes de, por si só, promover qualquer abalo e renovação disciplinar mais efetiva. Pelo contrário, como pode ser detectado no discurso de Claire Bishop, são incorporados à rede disciplinar e passam a compor 0 âmbito do esperado, pois são o que são: material, objeto sujeito a paradigmas e procedimentos não reestruturados e replicados no tempo.

Para o universo disciplinar da arte, centralizado na análise do que restou dos fatos — despojos como fotos, vídeos, áudio, depoimentos, reviews, memória -, e não no fato em si, tão ou mais importante que realizar é, sobretudo, registrar. Esta característica catalográfica, historiográfica, analítica e, sobretudo, retrospectiva, na qual o que se escreve é o que permanece enfatiza a narrativa e, por vezes, até prevendo-a ou direcionando-a. O processo de institucionalização e a gradativa entrada do Cine Falcatrua na área artística trouxeram consigo a necessidade de expandir questões narrativas e reflexivas, primordiais para a existência no campo artístico. Das pulsões críticas ancoradas em intervenções que miravam reconfigurações cotidianas mais efetivas, o Cine Falcatrua passou a dialogar, em face de sua nova conjuntura ${ }^{55}$, nos interstícios entre prática e discurso.

Por seu turno, Maruípe e Entretantos já nasceram imbuídos dessa necessidade. Ressalta-se que, desde a década de 1960 com o desenvolvimento de uma série de práticas artísticas experimentais que colocaram em xeque a noção modernista de obra de arte como objeto material em ações e conceitos - para os quais Lucy Lippard56 cunhou o termo "desmaterialização da arte", considerando as

55 Conforme já foi exposto, nesse momento, tanto a UFES quanto os membros do Cine Falcatrua estavam sendo processados.

$56 \quad$ Ainda em 1967, Lucy Lippard em conjunto com John Chandler escreveu o artigo The dematerialization of art publicado na Art International, n.12, em fevereiro de 1968. Posteriormente, a autora publicou Six Years: The Dematerialization of the Art Object from 1966 to 1972, no qual, editou e comentou uma série de eventos do período. 
aproximações com a "vida real" -, tornou-se cada vez mais necessário o suporte de aparatos materiais para essa produção imaterial: textos, fotografias, filmagens, dentre outros registros, para que não ocorra o que a mesma autora denominou, posteriormente, no texto Curating by numbers (2009) de amnésia cultural, "[...] impostas menos pela perda da memória do que pela estratégia política deliberada" (LIPPARD, 2009) 57.

Nesse sentido, como pode ser apreendido nos escritos tanto pelo coletivo Maruípe quanto 0 Entretantos existe uma acentuada preocupação em registrar suas ações. O coletivo Maruípe, por exemplo, quando realizou a Intervenção no Edifício das Fundações (2004) escreveu "[...] o foco é o processo, e o registro é peça fundamental - até agora realizamos cerca de quinhentas fotos, digitais e em papel, vídeos, anotações e croquis" (MARUÍPE, 2004)58. Na ocasião, do evento Paralela-ao-Mar (2004), na correspondência entre os participantes, a preocupação em registrar as ações foi também constantemente evocada59. O coletivo Entretantos, por outro lado, além das publicações impressas dos registros das duas edições do evento e exposição com fotos e materiais do projeto multipliCIDADE (2006), também, organizou e disponibilizou um vasto material das duas edições, na internet. Em ambos os casos, a cobertura por parte da imprensa foi praticamente nula. Exemplo disso pode ser detectado na correspondência entre os participantes do Pararela-ao-Mar, quando o entusiasmo inicial - "[...] estou divulgando para todos os meus contatos, artistas plásticos, diversas comunidades no Orkut, site Arte na Rede, Jornais A Tribuna e A Gazeta" (LEITE, 2004) - é convertido, posteriormente, em desapontamento - "Tai a prova de q santo de casa não faz milagre: 0 cubo branco ${ }^{60}$ divulgou, 0 informativo universidArte também [...], menos os jornais locais" (PINHEIRO, 2004)61.

LIPPARD, Lucy; CHANDLER, John. A desmaterialização da arte. Tradução de Fernanda Pequeno e Marina P. Menezes de Andrade. Rio de Janeiro: Arte \& ensaios. Revista do PPGAV/EBA/UFRJ, maio de 2013. LIPPARD, Lucy. Six Years: The Dematerialization of the Art Object from 1966 to 1972. New York: The University of California Press, 1973.

57 LIPPARD, Lucy R. Curating by numbers. Tate Papers, v. 12, 2009. Disponivel em: <http://www.tate.org.uk/research/publications/tate-papers/12/curating-by-numbers>. Acesso em: 10 abr. 2017.

58 Disponivel em: Disponível em: <http://maruipe.zip.net/>. Acesso em: 28 nov. 2016.

59 Para exemplificar, vale mencionar algumas delas: "[...] meu maior problema é em relação ao registro (vídeo e/ou foto) dessas ações pq não tenho maquina e sozinho só consigo tirar fotos da ação já concluída [...]" (BORËM, 2004); "[...]Se alguém puder mesmo fotografar ia ser muito bom [...]" (PAPE, 2004); "[...] levem tds seus equipamentos de registro amanhã à noite, teremos performances, ações e intervenções" (PINHEIRO, 2004), solicitou Elaine Pinheiro aos demais participantes.

$60 \quad 0$ Cubo Branco é um canal de divulgação, não produzindo textos, portanto, a divulgação ficou restrita a reprodução do release escrito pelo grupo.

$61 \quad$ Diversamente do coletivo Maruípe que destaca positivamente a divulgação de suas ações, dentre outros, no site Cubo Branco, o grupo dos Rejeitados, durante o período em que discutia a possibilidade de participar das ações de ocupação do prédio Prestes Maia, no final de 2003, questiona vigorosamente a publicação de uma nota informativa desse canal sobre o que eles pretendiam realizar. A discussão não ficou restrita aos seus membros, conforme é possivel detectar por meio da correspondência trocada com Fábio Carvalho, editor do site. 0 grupo solicitou que o Cubo Branco publicasse uma errata e incluísse 0 e-mail dos Rejeitados na listagem. 0 endereço eletrônico era canalvaginalcontemporaneo@yahoo.com.br, em evidente ironia ao site Canal Contemporâneo. 0 intuito ao aproximar essas distintas reações é ressaltar a clara diferença entre a visibilidade possivel das ações de um grupo com uma quantidade 
Diversamente dos coletivos Maruípe e Entretantos, o Cine Falcatrua "[...] ganhou projeção (nacional) por colocar em pauta a discussão sobre o poder e o controle da produção audiovisual" (JAREMTCHUK, 2007b, p.93) ${ }^{62}$, sua entrada no campo da arte contemporânea, ocorreu na convergência entre questões distintas, quando o grupo precisou traçar outras possibilidades de continuidade para o projeto. Necessitavam, por um lado, de maior autonomia para fomentar suas ações, como por exemplo, a livre utilização de equipamentos, que (segundo seus integrantes) apenas parcialmente e com alguns empecilhos eram cedidos pela universidade. Por outro, a discussão que interessava ao grupo era diversa das que estavam sendo postas pelos movimentos ligados ao audiovisual e, especialmente, sobre o cinema digital63. Além desses dois fatores, havia um terceiro, que pode ser detectado na observação contundente, mencionada em reportagem (ASSIS, 2004), que definia as atividades do grupo como criminais pelo representante da ADEPI, o processo em curso que acusava a universidade de "concorrência desleal" e a indagação em forma de afirmação de Gabriel Menotti sobre como sustentar as experimentações e perspectivas aventadas pelo grupo em um tribunal. Nesse sentido, a entrada do coletivo no campo da arte contemporânea - que teve como marco, para seus integrantes ${ }^{64}$, a seleção do coletivo, com o projeto CortaCurtas, no edital do projeto Rumos Artes Visuais 2005-2006 do Instituto Itaú Cultural - demarca uma fase distinta. Para Menotti, nesse momento, o grupo passou a operar mais como um coletivo de arte do que como um cineclube, visto que a "[...] pirataria acabou sendo recebida pelo mundo das artes como uma tendência estética emergente" (MENOTTI, 2015, p.106-107). Segundo o autor:

\footnotetext{
Nesse novo contexto, ainda que o projeto do grupo não tenha se alterado fundamentalmente, ele foi completamente reenquadrado: da curadoria de cinema, passou a implicar a produção de obras. A pirataria, que era um método para a primeira atividade, passou a ser como que um conteúdo da segunda - a característica que tornava a prática do cineclube particularmente relevante enquanto arte (MENOTTI, 2015, p.107).
}

maior de integrantes e com alguns nomes reconhecidos no circuito artístico nacional [ou em vias de ser] e um coletivo de menor porte e distante do eixo Rio-São Paulo.

62 JAREMTCHUK, Dária. Ações políticas na arte contemporânea brasileira. Concinnitas. Ano 8, volume 1, número 10, julho 2007.

63 A pesquisa de mestrado de Gabriel Menotti, de 2007, que originou o livro Através da Sala Escura... (MENOTTI, 2012), foi inspirada nas atividades experimentais do Cine Falcatrua, conforme informou o autor (MENOTTI, 2012, p.11-12). Segundo ele, o texto teve como questão desencadeadora o "descontentamento com os rumos tomados pela discussão sobre o cinema digital, particularmente obcecada com a natureza da imagem gerada por computador, sua resolução visual e circulação não autorizada". Preocupações, que para ele "nos fazem perder de vista algumas consequências mais expressivas que as redes telemáticas podem trazer ao meio cinematográfico" (MENOTTI, 2012, p.11). Por isso, desenvolve suas considerações "sobre as conjunturas sociotécnicas das quais ela não pode ser isolada" (MENOTTI, 2012, p.11), pois essas estruturas são apenas aparentemente neutras, "apontando para um circuito condicionado por múltiplas materialidades, onde os meios se encontram em contínuo desenvolvimento" (MENOTTI, 2012, p.11).

$64 \quad$ A afirmação consta em entrevista concedida à rádio universitária por alguns dos integrantes do Cine Falcatrua em 23 de janeiro de 2013. Disponível em: <http://www.universitariafm.ufes.br/noticias/cine-falcatrua-completa-10-anos-decriacao>. Acesso em: 14 dez. 2014. 
O reenquadramento do projeto no âmbito das instituições de arte, não pode ser desvinculado da inserção possível de poéticas políticas - especialmente aquelas que transitam na fronteira entre legalidade e ilegalidade - no contexto institucional. A questão é controversa por tentar conciliar um discurso artístico que clama autonomia e os limites reais de incluir no seu interior propostas que operam nas margens. Esse entrelaçamento complexo, no qual se fundem e se confundem os limites entre abordagens distintas, fica explícito quando se confronta a questão dos direitos autorais - objeto de preocupação do regulamento do programa Rumos Artes Visuais 2005-2006 -, com a seleção do Cine Falcatrua neste mesmo edital, por colocar em xeque o que versava 0 texto normativo65. Essa contradição entre a pretensão de radicalidade do discurso e as regras institucionais fica ainda mais evidente na edição do projeto Rumos Itaú Cultural 2015-2016. Neste, enquanto o cabeçalho inicial promete a possibilidade de uma "[...] criação sem amarras, sem fronteiras [...] sem ter de adaptar ideias a moldes preestabelecidos" no qual, "O artista é o protagonista. E a arte está fora da caixa" (EDITAL RUMOS 2015-2016, grifo meu), o item referente à forma como será efetuada a seleção, afirma que serão invalidadas as inscrições que "[...] desatendam a alguma questão legal" (EDITAL RUMOS 2015-2016)66.

Não é à toa que iniciativas radicais situadas fora do campo da legalidade adquirem, muitas vezes, salvaguarda no terreno artístico. Enquanto movimento social, as passeatas, ocupações, pichações, vandalismos, entre outros, recebem tratamento diferenciado pelas autoridades policiais. Algumas vezes, o uniforme artístico pode conceder um elixir protetor capaz de prolongar a permissibilidade, tornando-a imune por determinado período de tempo. Exemplo disso pode ser apreendido da declaração do artista pernambucano Lourival Cuquinha (que nessa época assinava como Lourival Batista) sobre Cinco atos criminosos que participei e que talvez possam ser chamados arte (BATISTA, 2007). Um desses cinco atos foi artraffic, iniciado em 2005 quando o artista residia na França. Trata-se de um colar feito com bolas de haxixe acompanhado por um manual de instruções de como usá-lo. O trabalho foi exposto no Palais Port Doré (Paris-França), participando ainda de uma performance na qual o artista fumava o colar na École Supérieure d'Art d'Avignon (França). Parado na fronteira da Suíça com a França transportando haxixe, o artista relatou que - possivelmente - não foi

65 A referência é ao item 9.1. Direito e deveres do regulamento, mais especificamente ao terceiro parágrafo, que afirma que 0 artista ou o grupo inscrito declara a "inexistência de plágio [...] bem como assegura a não utilização de obras de terceiros" assumindo "integralmente a autoria das mesmas", devendo responder por "reivindicações que envolvam direitos autorais de terceiros, inclusive indenizando o Itaú Cultural regressivamente caso seja acionado e/ou condenado" (Canal Contemporâneo, 2005). Ressalta-se que o regulamento não está mais disponível no site da instituição, entretanto, consta em uma versão comentada no site do Canal Contemporâneo (Canal Contemporâneo, 2005).

66 Cabe ressaltar que a partir da edição de 2013, os projetos que não atendessem as normas legais passaram a ser eliminados na pré-seleção. Questão que passou a impossibilitar uma possivel "negociação" entre a comissão de seleção e o proponente. 
deportado nem pagou multa porque mostrou aos policiais "[...] o manual de instruções e revelou a arte embutida na atitude" (2007). O trabalho também foi exposto e todo ele vendido na galeria Gentil Carioca (Rio de Janeiro). Refletindo sobre artraffic, ele afirmou que em trabalhos assim:

[...] só o conceito pode justificar uma não punição. Nestes casos [...] se eu não convencer, vou acabar preso. É obrigatória a performance do convencimento, de si mesmo até. Se você não tiver certeza, não convence a ninguém, como no caso da fronteira Suíça/França $(2007)^{67}$.

Há, entretanto, inúmeros exemplos diversos do caso relatado por Lourival Cuquinha, nos quais obras são retiradas de exposições públicas mesmo sem operarem na fronteira entre arte e legalidade. O trabalho Desenhando com terços da artista Márcia X que fazia parte da coletiva Erótica - os sentidos da arte com curadoria de Tadeu Chiarelli, no Centro Cultural Banco do Brasil no Rio de Janeiro, em 2005, é um exemplo. Nesse mesmo sentido ocorreu a retirada dos urubus que faziam parte da obra Bandeira branca do artista Nuno Ramos, na $29^{a}$ Bienal Internacional de São Paulo, em 2010. Se em Desenhando com terços, o argumento foi de ordem religiosa, já que grupos católicos ficaram ofendidos com a associação do terço à sexualidade, no caso de Bandeira branca68 foram os protestos de militantes ambientalistas, a repercussão na imprensa, dentre outros - "[...] criando um caldo de cultura próximo à violência e à intimidação", nas palavras do artista (RAMOS, 2010) - que levaram o Instituto Brasileiro do Meio Ambiente e dos Recursos Naturais Renováveis (IBAMA) de Brasília a reverter a licença concedida pelo setor no Sergipe e o laudo do IBAMA de São Paulo, abrindo, conforme sintetizou em entrevista Agnaldo Farias, um dos curadores daquela edição da Bienal, "[...] um precedente perigoso, pois quando uma instituição aceita que os próprios preceitos que ela mesma criou sejam feridos por ela própria, ela mesmo se desautoriza" $(2010)^{69}$.

Ao expor esses exemplos, o que se pretendeu foi colocar em questão não exatamente o que Pierre Bourdieu denominou de "autonomia da arte" - questão abordada em diversos dos seus textos 70 - que em maior ou menor grau, sempre foi relativa, mas indagar sobre o tipo de desvio que passou a guiar suas coibições no contexto mais recente: a tentativa de ser consensual com certos setores da sociedade.

67 BATISTA, Lourival. Cinco atos criminosos que participei e que talvez possam ser chamados arte. Recife: Revista Tatuí. Edição 02, maio de 2007.

$68 \quad \mathrm{Na}$ ocasião da remoção dos urubus, Nuno Ramos escreveu uma defesa muito lúcida de sua obra e, por extensão da possibilidade da arte continuar ser "a última experiência universalizante, ou ao menos não simétrica à discursividade do mundo" (RAMOS, 2010). RAMOS, Nuno. Bandeira branca, amor. Em defesa da soberba e do arbítrio da arte. São Paulo: Folha de S. Paulo, llustríssima. 17 de outubro de 2010.

$69 \quad$ FARIAS, Agnaldo (Entrevista concedia à Alexandre Nicolidi e Denis Nicola). A política na arte através da arte política. Revista Panorama Crítico (online), v. 08,15 out. 2010. Disponível em: <http://www.panoramacritico.com/008/entrevistas_02.php>. Acesso em: 10 abr. 2017.

70 Ver, por exemplo: BOURDIEU, Pierre. As regras da arte: gênese e estrutura do campo literário. Tradução de Maria Lúcia Machado. São Paulo: Companhia das Letras, 1996. 
A arte desfruta uma proteção especial que nem toda opinião possui, e disso os tribunais já se ocuparam com bastante frequência. A liberdade de opinião está garantida na Constituição, mas não o privilégio de expressá-la pública e oficialmente. Enquanto a arte dispuser de instituições que proporcionem esse privilégio, ela conservará sua função na nossa sociedade. Essa sociedade não é tão tolerante quanto diz e não aprova, exceto a arte, nenhuma outra autoridade que possa ter condições de colocar publicamente em discussão temas polêmicos e, sobretudo, tomar ela mesma posição (BELTING, 2012, p.94-95).

A intangibilidade apontada por Hans Belting, entretanto, considerando os exemplos expostos (aliados à discussão anterior relativa ao Cine Falcatrua), pode ser suavizada ou acentuada, não exatamente em função do que e como se discute, mas dá visibilidade alcançada e reclames resultantes. Nesse sentido, é necessário sublinhar que as atividades do Cine Falcatrua já tinham sido bastante divulgadas e que Nuno Ramos realizou uma versão similar de Bandeira Branca no Centro Cultural Banco do Brasil de Brasília, por dois meses em 2008, com as "mesmas três aves" (RAMOS, 2010).

\subsection{INICIATIVAS INDEPENDENTES E CIRCUITO INSTITUÍDO}

\subsubsection{Regras, conformações e antagonismos}

Da idealização à produção, a responsabilidade de emplacar objetivos, ideais, equipe, edital, seleção e registro dos empreendimentos quando protagonizados pelos agentes de fora das instituições oficiais pode não só resultar em renovação do quadro e perfil dos eventos de arte, mas também pode revelar algumas limitações no confronto entre o otimismo do discurso e sua efetiva implementação.

O Paralela-ao-mar, evento realizado pelo Maruípe em 2004, adotou uma relação ambígua com o circuito instituído, bem como a proposição de pressupostos não comuns aos eventos oficiais. Os posts diversos que informam a natureza do evento sublinham seu protagonismo e autonomia, ao mesmo tempo em que afirmam o diálogo com o evento promovido tradicionalmente pelo poder público, antecipando, por sua transformação ao longo do tempo, a metamorfose da própria ideia do projeto. $A$ demarcação, portanto, de territórios e autoria é a primeira informação apresentada:

através de uma iniciativa independente, o coletivo maruípe propõe a paralela ao mar, mostra que acontecerá simultaneamente ao salão do mar 2004, em vários pontos da cidade, a partir do dia 16 de dezembro [...] a intenção é discutir questões relacionadas às práticas artísticas com a cidade (MARUÍPE, 2004, grifo meu) ${ }^{71}$.

por iniciativa e tão somente iniciativa do coletivo maruípe estamos propondo a "paralela ao mar" ... uma exposição que terá abertura no mesmo dia da inauguração do salão do mar 
de 2004 e que acontecerá simultaneamente por vários pontos da cidade (IXKEMA, 2004, grifo meu) $)^{72}$.

A expressão iniciativa independente remete diretamente às seguintes questões: $O$ que significa ser independente? Qual o benefício de ser independente? O que ganha o participante de um evento independente? Liberdade e autonomia são evocadas imediatamente ao falar em independência e podem ser relacionadas a não subordinação diante das limitações legais impostas às instituições oficiais ou por meio dos seus patrocinadores. Esta rejeição à associação com o instituído é resultante da desconfiança com seus métodos e propósitos cuja materialização se efetiva, especialmente, pela divulgação das regras de participação. Assim, o edital com seu poder disciplinar (para usar o termo empregado por Michel Foucault73) — composto por um conjunto de normas que via de regra envolve renúncias na seleção, impõem categorias e, muitas vezes, dimensões limites para as obras, mas também oferece, quase sempre, algum tipo de premiação (seja ela dinheiro, bolsa de estudos, ou mesmo o direito à participação no evento etc.) - é um mecanismo de controle frequentemente acusado de parcialidade, direcionamento, ou mesmo, de imprecisão, e constitui importante marco contestatório da ação independente no Paralela-ao-Mar diante do salão hegemônico em questão, que apresentou a não seleção como diferencial74. Tal questão pode ser observada nos trechos abaixo retirados das discussões do grupo:

qualquer interessado pode se inscrever através do cadastramento no grupo de discussão http://br.groups.yahoo.com/group/paralelaaomar/, o q não torna a participação na exposição obrigatória (SILLFARLEY, 2004, grifo meu) ${ }^{75}$.

olá reginaldo,

72 Disponível em: <https://br.groups.yahoo.com/neo/groups/paralelaaomar/conversations/messages/3>. Acesso em: 12 jun. 2016.

73 0 termo poder disciplinar foi empregado por Michel Foucault em diversas ocasiões, entre as quais, no livro Vigiar e punir (FOUCAULT, Michel. Vigiar e punir: nascimento da prisão. Tradução de Raquel Ramalhete. 29 ed. Petrópolis: Vozes, 2004).

$74 \quad$ A ideia de não selecionar os participantes, entretanto, como é sabido, não constitui nenhuma novidade. Para ficar em apenas dois exemplos, cabe lembrar, o célebre Salão de 31, no qual, Lúcio Costa, recém-nomeado Diretor da Escola Nacional de Belas Artes, instituição responsável pela organização do Salão Nacional, aboliu a seleção, abrindo o Salão para artistas de todas as tendências. A reação acadêmica na forma de protestos e abstenções, além da longa polêmica na imprensa (de junho até setembro de 1931) "com José Mariano Filho, que condenava os rumos da Escola [...]. O debate culmina com a demissão de Lúcio Costa (AMARAL, 2003, nota 9, p.117). Além desse exemplo histórico, na edição anterior aquela do Salão Capixaba do Mar que o coletivo faz referência, foi a própria Comissão de Seleção e Premiação - formada por Maria Helena Lindenberg, José Aparecido Cirilo e Samira Margotto - que, colocando em xeque alguns itens do edital (que não fazia referência, por exemplo, ao fato que o Salão era de arte contemporânea, desencadeando a inscrição de inúmeros artistas com "pinturas de marinhas"), aceitou obras que não se enquadravam dentro do parâmetro não expresso de forma clara. Essa tomada de posição da Comissão deve-se ainda ao fato que para efetuar sua inscrição o artista precisava enviar obras e não apenas projetos. Cf: ACQUARONE, Francisco. História das Artes Plásticas no Brasil. (Atualizada por Leda Acquarone de Sá) Rio de Janeiro: Edição do atualizador, 1980; AMARAL, Aracy (Org.). Correspondência Mário de Andrade \& Tarsila do Amaral. São Paulo: EDUSP, 2003; SECRETARIA MUNICIPAL DE CULTURA. Catálogo do $5^{\circ}$ Salão Capixaba do Mar. Vitória: SEMC/Casa Porto das Artes Plásticas, 2003.

75 Disponível em: <https://br.groups.yahoo.com/neo/groups/paralelaaomar/conversations/messages/50>. Acesso em: 09 mai. 2017. 
já está dentro, confirmada sua participação por vc mesmo!! a paralela é um projeto coletivo, e mesmo q a proposta tenha sido lançada pelo maruípe, seu caráter é justamente trabalhar com iniciativas independentes. cada pessoa é responsável pelo seu trabalho e por estabelecer parcerias com os outros participantes e, assim, viabilizar 0 desenvolvimento, montagem e registro das propostas (PINHEIRO, 2004d, grifo meu) ${ }^{76}$.

Assim, tornando acessível a participação no Paralela-ao-Mar a qualquer interessado, 0 Maruípe subverte a lógica restritiva do evento oficial ao qual faz referência. A não seleção figura, portanto, como forma de enfrentamento sutil, permitindo que qualquer um, artista ou não, com qualquer estilo, anacrônico ou contemporâneo, atendendo ou não à intenção de discutir questões relacionando às práticas artísticas com a cidade, seja agraciado com a participação no evento coletivo ${ }^{77}$. Contudo, cabe indagar qual é à vantagem ou retorno na associação com o evento alternativo-independente: em suma, qual é o benefício voltado ao participante do evento? Se cada proponente, como mencionado na citação acima, é responsável inclusive pela produção e registro de seu projeto, não restando nada além do trabalho e dos gastos na participação de um evento "paralelo", a outro, com premiação, produção e registro do trabalho, não resta outra conclusão senão aquela que aponta para o desejo de ser protagonista, de fazer parte de um movimento que permitiria dispersar altruisticamente sua poética. Outra possibilidade de leitura, todavia, aponta para um confronto indireto ao oficial, em que a não seleção promovida pelo Paralela-ao-Mar era apenas uma forma não declarada de oposição ao procedimento restritivo do VI Salão Capixaba do Mar.

Uma análise mais atenta revela, entretanto, as contradições nos enfrentamentos do evento independente no que tange à participação democrática e à autonomia diante do oficial. A inexistência de critérios ou limites de seleção no Paralela-ao-Mar tem seu brilho ofuscado quando se detecta que, embora possuíssem intenções de auxílio mútuo entre os participantes na execução das propostas, algumas produções foram inteiramente individuais ou não se efetivaram. Como exemplo extremo da não materialização, é possível citar a tentativa de Cristina Pape, artista moradora de outra cidade, em participar do evento. Após diversas negociações, orientações e comprometimento entre a artista e demais integrantes do evento moradores da cidade de Vitória, a obra Intervenção com peixes+cortina de fumaça ${ }^{78}$ (ao que tudo indica na leitura da correspondência do grupo) não foi realizada por conta da

76 Disponível em: <https://br.groups.yahoo.com/neo/groups/paralelaaomar/conversations/messages/107>. Acesso em: 09 mai. 2017.

$77 \quad$ Nesse sentido, por exemplo, ainda que a intenção expressa pelo grupo tenha sido "discutir às práticas artísticas com a cidade", a proposta do artista Reginaldo Leite, aceito pelo coletivo, foi realizar uma mostra virtual com "[...] 15 pinturas inéditas, todas elas abstratas em que suas formas lembram motivos ligados ao mar, assim como golfinhos, cavalos marinho, peixes, baleia, tubarões, enguias, fundo do mar, atlântida e dilúvio". Disponível em: <https://br.groups.yahoo.com/neo/groups/paralelaaomar/conversations/messages/105>. Acesso em: 09 mai. 2017.

$78 \quad$ A obra proposta por Cristina Pape, consistia em dispor peixes pendurados em um poste, segundo ela "[...] eu costumo usar materiais perecíveis e que de certa forma perturbem um pouco a ordem do dia. Gostaria de colocar num poste, escolham um bem interessante, por favor, vários peixes pendurados. Manjubinhas, sardinhas, e pode já ser tudo meio passado, meio podre mesmo, penduradas pela cauda e amarradas no poste" (PAPE, 2004). Cabe sublinhar que, 
falta de um staff mínimo necessário para que um evento possa acontecer ${ }^{79}$. Cabe ressaltar que, reforçando essa suposição, em 02 de março de 2005, a artista solicitou seu desligamento do grupo: "Peço que me tirem do grupo" (PAPE, 2005) ${ }^{80 .}$

É o próprio paralelismo do evento independente que esvanece qualquer possibilidade de autonomia, uma vez que a referência, convertida rapidamente em dependência pelo discurso conciliatório dos próprios integrantes, está dada pelo universo restrito do evento oficial. 0 conceito promotor do Paralela-ao-Mar não faz menção à cadeia de produção do universo artístico, mas é meramente tomado do salão "paralelo". Em um post, o participante nennaferreira indagou: "Uma pergunta modelito filosófico: existe algum 'conceito' na relação com o salão do mar?" (nennaferreira, 2004) ${ }^{81}$, seguido de apenas uma resposta de Elaine Pinheiro refutando a relação restrita ao mar, mas englobando-o num conceito mais amplo com a cidade, que, em sua concepção, seria também tratado pelo salão modelo (PINHEIRO, 2004)82. Embora este seja um posicionamento pessoal de uma das integrantes, não deixa de ser revelador o espelhamento do evento promovido pela Casa Porto das Artes Plásticas, direcionando a análise à constatação de que os motivos que levaram à confecção do evento alternativo-independente, dentre eles a exclusão da seleção, eram mais políticos do que estéticos. Portanto, se até mesmo as diretrizes filosóficas - ainda que presumidas - do empreendimento autônomo são mimetizadas, não se pode falar exatamente em independência.

Por outro lado, é possível relativizar o grau de motivação política contido na proposta do grupo, uma vez que há uma tentativa clara de eliminar qualquer aparência de enfrentamento institucional ${ }^{83}$. A

naquela edição do Salão Capixaba do Mar, Arthur Barrio participou como artista convidado, realizando a obra Para quando peixes no mar houver, com peixes e sal grosso, que foram se deteriorando no decorrer do evento, aberto em 16 de dezembro de 2003 e encerrado em 30 de janeiro de 2005. Entretanto, não foi localizada na correspondência do grupo qualquer referência explícita entre a obra proposta por Cristina Pape com o trabalho de Arthur Barrio. Disponível em: <https://br.groups.yahoo.com/neo/groups/paralelaaomar/conversations/messages/27>. Acesso em: 20 mai. 2017.

$79 \quad[. .$.$] eu estou dentro. Posso mandar um vale postal para alguém comprar o que eu preciso. O problema é onde e$ quem colocaria 0 trabalho? Seria bom fotografar (PAPE, 2004). Disponível em: <https://br.groups.yahoo.com/neo/groups/paralelaaomar/conversations/messages/207>. Acesso em: 16 out. 2016.

cristina, o pessoal q combinou de fazer sua intervenção comigo, no final de semana, sumiu. liguei para o celular de tds eles, mas sempre caixa postal, desligado ou fora da área de cobertura. durante a semana fica complicado pra mim, mas estou disposta a conciliar os horários e realizar logo a ideia [...] fazer a intervenção sozinha é mais difícil, por isso seria interessante a participação de mais pessoas, entre outros motivos. onde estão as pessoas q se comprometeram? (PINHEIRO, 2004). Disponível em: <https://br.groups.yahoo.com/neo/groups/paralelaaomar/conversations/messages/136>. Acesso em: 14 mai. 2017.

80 Disponível em: <https://br.groups.yahoo.com/neo/groups/paralelaaomar/conversations/messages/207>. Acesso em: 16 out. 2016.

81 Disponível em: <https://br.groups.yahoo.com/neo/groups/paralelaaomar/conversations/messages/25>. Acesso em: 09 mai. 2017.

$82 \quad$ Nas palavras da artista: "[...] a proposta do paralela não se restringe ao 'mar', e sim inclui esse tema. penso q 0 conceito versa sobre a cidade. pelo q sei, a curadoria do salão do mar tb explora essa questão." Disponível em: <https://br.groups.yahoo.com/neo/groups/paralelaaomar/conversations/messages/73>. Acesso em: 09 mai. 2017.

83 Porém, há uma tentativa sutil de enfrentamento ao evento oficial, especialmente aos anacronismos do edital. Tal questão pode ser detectada em algumas mensagens do grupo de discussão. Exemplo disso, é a pergunta do integrante do 
primeira delas, incluída no próprio release apresentado à imprensa, demonstra o objetivo do Paralelaao-Mar como um complemento ao salão governamental, cuja função seria não a de contestar o modelo de política artística pública, mas sim o de se juntar a ela, ajudando o poder público com a tarefa de levar cultura à cidade. A segunda ação consonante com a anterior foi à busca de apoio ou reconhecimento das instituições oficiais expresso na mensagem da integrante do grupo Elaine Pinheiro - embora não saibamos o que significa de fato a expressão "apoio total": recursos, espaços, equipe, know how, equipamentos, ou mero apoio moral? Não fica claro no texto... —, revela o desejo de figurar ao lado e não o de ruptura ou contestação.

a paralela ao mar foi pensada justamente no sentido de estabelecer um diálogo com o
salão e ampliar o corredor cultural já existente no centro da cidade, criando um espaço
aberto a todos os interessados em executar suas propostas (MARUÍPE, 2004, grifo meu)
o artista e coordenador da casa porto das artes plásticas e do salão do mar, celso adolfo
salles ramos, já está a par da paralela e deu apoio total ao projeto. igualmente, alguns
artistas selecionados para o salão do mar tb irão participar da paralela (PINHEIRO, 2004,
grifo meu) ${ }^{85}$.

O Coletivo Entretantos, por outro lado, utiliza um paradigma diverso ao do Maruípe, adotando os protocolos que as instituições oficiais praticavam. O pragmatismo na condução do evento multipliCIDADE 2006 e 2007, no qual controle é a palavra-chave, demonstra que o enfrentamento político diante do oficial aconteceu apenas no quesito protagonismo, marcado pela reiteração da expressão de entrada padrão dos coletivos já destituída de qualquer significado de oposição ao sistema oficial. Desta vez, iniciativa independente não pretendeu a renovação do modelo, questionamento de práticas, mas tão somente a demarcação autoral.

O projeto multipliCIDADE, através de uma iniciativa independente do Coletivo Entretantos, abre caminhos para a multipliCIDADE de experiências contemporâneas materializadas em trabalhos artísticos, através de diálogos entre conceituais estéticos e os questionamentos que implicam contemporaneidade por meio de várias linguagens, na llha de Vitória (ENTRETANTOS, 2006, grifo meu).

A organização do multipliCIDADE, por iniciativa do Coletivo Entretantos, se traduz num ato de coragem, planejamento e ousadia, que inseriu a cidade de Vitória no Circuito Independente, que hoje se organiza a partir da descentralização do eixo artístico Rio de Janeiro x São Paulo. O retorno que temos recebido de artistas de todo o país nos deixa

Maruípe Silfralem a um artista que foi selecionado no Salão Capixaba do Mar e que também estava participando do Paralela-ao-mar. "Gostaria de saber se aquela idéia, de vc expor o mesmo trabalho no salão e na paralela, vc ainda pretende desenvolver?". Em resposta, o artista (Marcelo Gandini) apenas informa que faria uma mostra virtual com alguns de seus trabalhos. Cabe ressaltar que, no regulamento do evento oficial, constava a seguinte cláusula: "Só serão aceitas inscrições de obras produzidas a partir de 2003, e que não tenham participado de outros eventos no Espírito Santo (INÉDITAS)". Disponível em: <https://br.groups.yahoo.com/neo/groups/paralelaaomar/conversations/topics/109>. Acesso em: 09 mai. 2017.

84 Disponível em: <https://br.groups.yahoo.com/neo/groups/paralelaaomar/conversations/messages/50>. Acesso em: 09 mai. 2017.

85 Disponível em: <https://br.groups.yahoo.com/neo/groups/paralelaaomar/conversations/messages/101>. Acesso em: 09 mai. 2017. 
certos do caminho que vimos trilhando. Este é apenas o começo de tudo (SANTOS; TEIXEIRA, 2006, p.5, grifos dos autores).

A emulação do modelo oficial pode ser encontrada na precisão contida no regulamento dos eventos, bem como na delimitação concreta dos serviços oferecidos pelo evento tanto aos participantes, na forma de premiação, quanto ao público geral, na forma de uma programação organizada. Não há abertura às massas na produção e coordenação do evento que são encerradas nos membros que compõem o coletivo - Marcus Vinícius, Rafael Massena e Renato Marianno, (SANTOS; TEIXEIRA, 2006, p.6) - e apoiadores na condição de coadjuvantes - Coordenação de Artes Visuais da SECULT e SPDC (SANTOS; TEIXEIRA, 2006, p.6). Os canais de comunicação servem essencialmente para divulgar as atividades e não para coletar ou debater democraticamente a condução do evento 86 .

O espírito objetivo do Entretantos permite, portanto, a realização do evento com precisão de selecionados e produção na execução dos projetos. Para isso, replica no regulamento a normatização padronizada nos editais oficiais, em que data de realização e inscrição, documentação para inscrição, formas de recebimento das inscrições, critérios de seleção e vantagens para os selecionados são discriminados em documento claro, curto e separado por cláusulas. Se o evento Paralela-ao-Mar, promovido pelo Maruípe, demonstrava inclinação ao espírito de construção coletiva do próprio evento, em seus aspectos filosóficos e de produção, eliminando o máximo de hierarquias existentes entre idealizadores e participantes, com o multipliCIDADE é possível detectar uma política com papéis determinados e hierarquias estabelecidas, a partir dos quais o controle e decisões sobre o caráter do evento não parecem ser partilhados.

A edição 2007 do multipliCIDADE, porém, é mais comedida e evita enaltecimentos de ineditismo do evento como foi divulgada na edição anterior, uma vez que ele não foi o único, nem o primeiro a inserir a cidade de Vitória no circuito de eventos independentes, como pôde ser visto nos casos mencionados - basta lembrar do evento do Maruípe e das inúmeras ações promovidas pelo Cine Falcatrua —, ao mesmo tempo em que se mostrou mais generoso na concessão de maior espaço de visibilidade aos seus apoiadores, apresentados de imediato no cabeçalho do regulamento:

\footnotetext{
86 Debater democraticamente a condução de um evento, como foi conduzido pelo coletivo Maruípe, talvez se configure mais como exceção do que norma entre os coletivos no Brasil. Nesse sentido, cabe mencionar uma reflexão de Graziela Kunsch, em e-mail datado de 01 de dezembro de 2003, que consta na correspondência trocada entre os participantes do projeto Rejeitados (que será posteriormente aqui abordado). Segundo ela: "[...] os rejeitados são [...] um dos poucos coletivos em que percebo/vivencio um processo de fato. Podem não ser 31 coletivos como gostamos de propagandear, podem ser umas poucas pessoas, uns poucos e-mails, mas acho que descobrimos uma forma de fazer juntos, de (não) fazer juntos!". Disponível em: <http://www.geocities.ws/rejeitadosnonono/>. Acesso em: 20 mai. 2017.
} 
O Coletivo Entretantos, em parceria com a Casa Porto das Artes Plásticas, Secretaria de Cultura da Prefeitura Municipal de Vitória, Sub-Gerência de Artes Visuais da Secretaria de Cultura do Espírito Santo, Secretaria de Produção e Difusão Cultural da UFES, Sindicato dos Artistas Plásticos Profissionais do Espírito Santo e Centro de Artes da UFES, através do FACITEC - Fundo de Apoio à Ciência e Tecnologia, torna público que se encontram abertas de 25 de julho a 14 de setembro de 2007 as inscrições para projetos de ações e intervenções artísticas e oficinas práticas e/ou teóricas, a realizar-se de 05 a 14 de outubro de 2007, em Vitória - ES, no multipliCIDADE 2007 (ENTRETANTOS, 2007).

Cabe sublinhar que a parceria mencionada com a Casa Porto das Artes Plásticas ${ }^{87}$, a primeira citada no regulamento, ficou praticamente restrita à cessão do espaço para a realização da exposição Dedo de Moça, da qual Marcus Vinícius (integrante do coletivo) assinou a curadoria. A parceria com a Subgerência de Artes Visuais da SECULT, por intermédio da Galeria Homero Massena, foi maior. Analisando os documentos do evento, na edição de 2006, por exemplo, antes da realização das intervenções na cidade, o grupo promovia encontros diários na galeria, tendo utilizando também 0 espaço para a promoção de um ciclo de palestras. Na edição de 2007, a parceria foi ampliada, constando no regulamento que as propostas deveriam ser enviadas ou entregues no endereço da Galeria Homero Massena e não mais no local mencionado na edição anterior, um bairro residencia|88 de Vitória.

O regulamento do multipliCIDADE, tanto na versão 2006 quanto 2007, deixa claro os limites, não muito mais elásticos que os oferecidos pelo Paralela-ao-Mar, mas, em todo caso, claramente delimitados, no que se refere à premiação daquele que se submete à seleção do evento. Suporte de produção e possibilidade de figurar nos registros do evento são as retribuições pela participação, além, é claro, da possibilidade de contribuir para o mundo da arte independente, premiação sempre implícita em eventos militantes oficiais ou não. Embora haja delimitação clara de que os recursos de execução seriam financiados pelo proponente, o suporte à execução é prometido no regulamento:

A execução dos projetos selecionados terá apoio logístico da produção do multipliCIDADE e poderão tanto ser executados coletivamente ou pelo artista.

Os custos com material e/ou equipamentos utilizados nas ações, bem como transporte, hospedagem e alimentação, ficarão sob responsabilidade do proponente, que deverá listar

$87 \quad$ Além da cessão do espaço, coube à Casa Porto das Artes Plásticas, apoio na montagem e divulgação da exposição Dedo de Moça. É necessário sublinhar que a instituição não foi consultada sobre a inserção do seu nome no regulamento, nem para opinar sobre a proposta do evento em questão. Portanto, ainda que a intenção dos realizadores do multipliCIDADE tenha sido agradar, a não diferenciação entre os termos parceria e apoio indicam uma relação não existente que induz a pressuposição de uma construção conjunta ou concordância com o regulamento do evento por parte da Casa Porto. Ainda que por inversão é possível traçar uma aproximação entre a atribuição da autoria indevida para a instituição e ao transeunte como coautor em alguns dos trabalhos efetuados no espaço público no multipliCIDADE. Ambos são instrumentalizados, entretanto, os nomes dos transeuntes (denominados de coautores, por alguns artistas/coletivos) são omitidos, enquanto o da instituição é enfatizado. É necessário esclarecer que, no período em questão, a coordenação desse espaço estava sob a responsabilidade da autora desta pesquisa.

$88 \quad$ Na edição de 2006, constava no regulamento que os trabalhos deveriam ser enviados para o seguinte endereço: A/C Marcus Vinícius - Coletivo Entretantos - Avenida Santo Antônio, 552, Santo Antônio, Vitória - ES 29025-000. 
previamente suas necessidades no projeto. A Comorg [Comissão Organizadora] do multipliCIDADE custeará o material necessário para a realização das oficinas.

Não arcaremos com despesas de passagem, hospedagem e/ou alimentação dos artistas ou grupos selecionados, mas buscaremos alternativas para hospedar os interessados em montar o próprio trabalho e/ou ajudar na montagem dos demais. Caso exista este interesse, ele deverá estar descrito no projeto (ENTRETANTOS, 2007).

$\mathrm{Na}$ ânsia de figurar como uma instituição ou ao lado das instituições, o regulamento se apresenta na forma de verdadeiro contrato, replicando clichês normativos: regras rígidas, corpo de jurados, comissão de organização. Além de professar sentenças com pretensões democráticas, que causariam estranheza mesmo em eventos oficiais realizados no espaço público (o "acesso às ações contempladas deverá ser obrigatoriamente público e gratuito", conforme consta no regulamento de 2007), que figuram dissonantes com a falta de premiação não altruística: dinheiro, bolsa de estudos, financiamentos etc..

O artista ou grupo selecionado ficará obrigado a cumprir fielmente os termos deste regulamento de seleção;

A assinatura da ficha de inscrição implica na aceitação integral deste regulamento;

As decisões das comissões são soberanas e irrecorríveis;

Os casos omissos relativos a este regulamento serão decididos pela Comorg (Comissão de Organização) do multipliCIDADE (ENTRETANTOS, 2007).

O não enfretamento direto às instituições mencionadas ou ainda as tentativas de aproximação podem ser entendidas considerando que o espaço concedido para práticas mais experimentais no contexto artístico de Vitória, entre os anos finais da década de 1990 até aproximadamente 2008, era relativamente reduzido. Sem pretender traçar um panorama amplo e atendo-se somente a alguns exemplos de espaços que dispunham de maior infraestrutura, talvez seja possível afirmar que tanto a Galeria Homero Massena quanto a Casa Porto das Artes Plásticas figuravam com certo destaque no sentido de incentivar a produção de jovens artistas, especialmente com uma produção mais experimental. A primeira por ter seu calendário expositivo -, sobretudo a partir de 2003 - voltado para a produção de artistas iniciantes, e a segunda, em particular, por ser responsável pelo Salão do Mar que, do seu período inicial (1999) até sua última edição (2008), disponibilizava, via suas premiações, recursos financeiros para os artistas, diversamente dos demais espaços no Espírito Santo, até aquele momento ${ }^{89}$, além de ceder seu espaço para produções experimentais ${ }^{90}$. Ainda que de forma

89 Tal questão foi alterada a partir de 2008, quando o governo do estado do Espírito Santo instituiu o Fundo de cultura e criou o Plano de cultura do estado, em função da exigência do Ministério da Cultura (MinC) "para que cada estado e município tivesse seu CPF (Conselho, Plano e Fundo de cultura) [...]. Daí então foram elaborados editais anualmente visando atender aos anseios do setor [...]" (OLIVEIRA FILHO, 2014, p.125). Foi em 2008, que teve início, por exemplo, 0 prêmio Atelier de Pintura Galeria Homero Massena, bolsa residência com duração de cinco meses. OLIVEIRA FILHO, Francisco Edilberto de. As políticas públicas de cultura no Espírito Santo entre 2007 e 2014. 2014. Dissertação 
pontual, o Museu Vale, por exemplo, tenha realizado mostras que incluíam a produção local mais recente - sendo possível mencionar as exposições Desiderata: inventário do desejo (2002) ${ }^{91}$ e $1+7$ Arte contemporânea no Espírito Santo (2008) ${ }^{92}$ - elas eram mescladas com a inclusão de artistas com trajetória já consolidada. O Museu de Arte do Espírito Santo Dionísio Del Santo (MAES), em ocasiões esparsas, também cedeu seu espaço para a produção mais experimental, entre as quais, Linha Imaginária93: passagem sob os olhos (2001) ${ }^{94}$ e a mostra Falcatrua de Conteúdos Livres, como parte da programação 10: MAES Vídeo (2005).

(Mestrado em Teoria e História da Arte do Centro de Artes) - Universidade Federal do Espírito Santo, 2014; TEIXEIRA, Bernadette Rubim. Galeria Homero Massena: interfaces entre políticas públicas estaduais e as artes visuais no Espírito Santo. 2009. Dissertação (Mestrado em Artes) - Universidade Federal do Espírito Santo, 2009, p.163.

$90 \quad$ Além do exemplo já mencionado da cessão do espaço para a realização da exposição Dedo de Moça, ainda no ano de 2007, a Casa Porto das Artes Plásticas também atendeu parcialmente (o pedido incluía, além de passagens aéreas, hospedagem e alimentação dos participantes, entretanto, só foi possível disponibilizar passagens do eixo Rio-São Paulo) a solicitação de apoio e patrocínio para as palestras realizadas no seminário e mostra de vídeos Se Repete como Farsa, concebida pelo Cine Falcatrua, como parte das atividades do Encontro Regional de Estudantes de Arquitetura e Urbanismo (EREA). É necessário esclarecer o significava ceder o espaço para grupos independentes pelo viés institucional. Mais do que abnegar do protagonismo de assinar o evento, essas cessões, algumas vezes, implicavam renúncias diversas, incluindo desde negar o espaço para outros setores da própria instituição ou para empresas de produção cultural beneficiadas com recursos financeiro e logístico, até assumir riscos de ordem diversa. Em 27 de abril de 2007, dia da abertura do evento Se repete como farsa, por exemplo, a equipe de produção do coletivo informou que estava com problemas técnicos que impossibilitariam as projeções dos vídeos que seriam realizadas na área externa da instituição. Para tanto, entraram em contato com uma empresa prestadora de serviços para a PMV que estava no local e que poderia emprestar o equipamento que necessitavam. Para fazer o empréstimo, entretanto, o responsável pela empresa solicitou que o mesmo fosse formalizado por um termo que condicionava o pagamento do equipamento, no caso da ocorrência de algum dano. Cabe sublinhar que, exercendo na época o cargo de Coordenadora da instituição, a autora assinou um termo de responsabilidade com valor aproximadamente dez vezes superior ao seu salário, ciente de que, a PMV não restituiria 0 mesmo. Mais do que relatar um caso corriqueiro de ordem administrativa, o que vale destacar é que os gestores das instituições, ao optarem por apostar nas produções mais experimentais, não são meros agentes passivos no processo, como muitas vezes é sugerido em alguns estudos. Em sentido oposto, Hal Foster (2015) inclui nos agradecimentos do seu livro Bad New Days: art, criticism, emergency, o comprometimento dos responsáveis por algumas instituições culturais de Nova York que continuam a fazer da cidade "[...] um lugar especial para a arte inovadora e o pensamento independente". FOSTER, Hal. Bad New Days: art, criticism, emergency. Verso Books, 2015, p.9.

91 A exposição constitui praticamente uma exceção na trajetória do Museu Vale, voltado, especialmente, para a exibição de mostras de artistas consagrados no panorama nacional. Desiderata: inventário do desejo ocorreu entre 10 de abril até 31 de agosto de 2002. Quinze artistas locais participaram da mostra, organizada por Evangelina Seiler: Andréa Abreu, Edison Arcanjo, Elisa Queiroz, Fabrício Coradello, Hélio Coelho, Hilal Sami Hilal, José Cirillo, Juliana Morgado, Júlio Tigre, Lara Felipe, Orlando da Rosa Farya, Rosana Paste, Rosindo Torres, Thiago Lessa e Yvana Belchior.

$927+1$ - Arte contemporânea no Espirito Santo foi realizada entre 1 de novembro de 2008 até 15 de fevereiro de 2009, tendo como curadores Almerinda Lopes e Ronaldo Barbosa. A coletiva, em comemoração aos dez anos de atividade da instituição, tinha como artista homenageado Dionísio Del Santo, que foi adotado como espécie de âncora para a discussão proposta pela curadoria. No site da instituição, é afirmado que: "A mostra presta uma especial homenagem ao artista Dionísio Del Santo (1925-1999), que 'será uma espécie de figura interativa da exposição', como explica a curadora. Os artistas e designers contemporâneos que estão na exposição 'recodificam e atualizam o pensamento concretista deste capixaba que defendeu o rompimento das fronteiras entre arte e vida', diz Almerinda Lopes. 'A escolha privilegiou um leque diferenciado de linguagens contemporâneas, cujas ações, materiais e suportes se caracterizam pelo seu caráter inovador, pela coerência e pela ousadia criativa', afirma Almerinda Lopes." Além do artista mencionado, foram selecionados Regina Chulam, Filipe Borba, Tom Boechat, Paulo Vivacqua, grupo Cine Falcatrua, Álvaro Abreu e Gustavo Vilar. Disponível em: <http://museuvale.com/site/website/Exposicoes.aspx?id=15\&Page=4>. Acesso em: 20 abr. 2017.

93 Cabe ressaltar que o projeto Linha imaginária era coordenado por Sidney Philocreon e Mônica Rubinho, ambos residentes na cidade de São Paulo. Ver: <http://cultura.estadao.com.br/noticias/geral,linha-imaginaria-faz-mapa-das-artesno-brasil,20010104p8695>. Acesso em: 20 abr. 2017. 
Assim, tendo como referência as ações conduzidas pelos coletivos Maruípe e Entretantos, não é possível falar em enfrentamento às instituições, como foi realizado por alguns coletivos ou individualmente por artistas desse período ${ }^{95}$. Nesse sentido, o projeto denominado de Rejeitados, enviado ao $9^{\circ}$ Salão da Bahia (2002) $)^{96}$ constitui um caso diametralmente distinto desses dois coletivos capixabas.

Ricardo Rosas (2006) utilizou as ações desenvolvidas pelos Rejeitados, formado por um "coletivo de coletivos" como exemplo paradigmático de novo momento no cenário artístico brasileiro. 0 autor informou que o agrupamento surgiu da discordância com os padrões de seleção do Salão da Bahia em 2002, tendo sido construído por trocas de "[...] e-mails coletivos, em cujas discussões [...], pode-se ter, em meio ao caos linguístico, manifestos, propostas, mensagens desaforadas e contrapropostas, um painel vigoroso das discussões polêmicas" (ROSAS, 2006a, p. 2).

Em 2007, visando esclarecer alguns aspectos do projeto coletivo, Graziela Kunsch escreveu:

\begin{abstract}
[...] a nossa proposta era que cada pessoa ou grupo inscrevesse um projeto de "correspondência", intitulado "rejeitados", acrescentando no projeto um parágrafo com 0 "critério de exclusão". "Este projeto só poderá ser aceito se todos os trabalhos chamados rejeitados forem aceitos". (rejeitados não vinha entre aspas, de modo que poderia significar os quase 1.700 rejeitados e não apenas os projetos que tinham esse nome) (KUNSCH, $2007)^{97}$.
\end{abstract}

\footnotetext{
$94 \quad$ A mostra realizada entre 30 de novembro de 2000 até 04 de março de 2001. Os artistas participantes foram: Domingos Senno, Elisabete Perez, Guilherme Machado, Julieta Machado, Mônica Rubinho, Néle Azevedo e Sidney Philocreon. Disponível em: <https://projetolinhaimaginaria.blogspot.com.br/2010/02/passagem-sob-os-olhos-2000-2001space.html>. Acesso em: 20 mai. 2017.

95 Um dos enfrentamentos mais radicais e, muito provavelmente o mais longo, é o projeto "Cartas ao sistema de arte" de Ana Amorim. Neste, a artista recusa que sua obra coexista ao lado de instituições capitalistas. 0 estopim para a criação do projeto foi o convite para participar, junto com outros artistas de renome no cenário nacional, de um fascículo sobre arte contemporânea brasileira que teria uma propaganda de uma nova linha de produtos da empresa farmacêutica Wyeth. Em 19 de abril de 2001, ela escreveu ao curador Tadeu Chiarelli, recusando e justificando a não participação no projeto. "[...] estou passando por um conflito interno tremendo, de um lado você com o projeto do fascículo sobre artistas que estão trabalhando agora no Brasil (que eu acho superimportante), e de outro a Wyeth." Analisando de forma panorâmica as postagens da artista em seu blog, entre o momento inicial até 14 de abril de 2017, percebe-se que, paulatinamente as respostas dos agentes do campo artístico as suas indagações foram rareando e que, nos últimos anos prevaleceu em seu blog, reproduções de textos com os quais a artista parece se identificar com a postura assumida pelos autores. De qualquer forma, é perceptível sua tentativa de levar a cabo sua sentença messiânica que finaliza a breve nota introdutória do projeto "Cartas ao sistema de arte": "Esse projeto só vai terminar no final da minha vida". Disponível em: $<$ http://questoes.blogs.com/>. Acesso em: 02 jul. 2017.

96 Com pequenas alterações e alguns acréscimos, parte das questões que serão aqui expostas sobre o projeto Rejeitados foi retirada do artigo de minha autoria, apresentado na ANPAP, em 2015. MARGOTTO, Samira. Nos meandros de tempos convergentes, divergentes e paralelos. Santa Maria (RS], ANPAP, 2015. Disponível em: <http://anpap.org.br/anais/2015/simposios/s10/samira_margotto.pdf>. Acesso em: 20 mai. 2017.

97 A pontuação e a explicação entre parênteses, depois da citação, são do texto original. Disponível em: <http://www.artesquema.com/2007/10/30/infelizmente-exposicao-nacional-de-nao-curriculos/>. Acesso em: 25 mar. 2015.
} 
A concepção da proposta dos Rejeitados colocava em xeque primeiramente o edital do Salão, que previa a seleção de trinta projetos, enquanto eles almejavam ultrapassar esse número, enviando trinta e um trabalhos, constando em todos eles a sentença: "este projeto só poderá ser apresentado (aceito) se todos os demais trabalhos chamados de rejeitados forem aceitos". Mesmo admitidos no Salão, o grupo não acatou a proposta do júri de seleção que apresentou como solução editar a iniciativa, expondo todos os projetos sobre uma mesa, como se fossem apenas um. Após intenso debate, o grupo decidiu criar uma página na internet com todos os e-mails trocados entre eles, 0 endereço do site constaria tanto na exposição no Museu de Arte Moderna da Bahia (MAM/BA) quanto no catálogo. Nesse sentido, um dos integrantes, identificado como Paulo98 escreveu:

[...]. Desta maneira, estaríamos ocupando o espaço do salão e o do catálogo, mas nos negando a ocupá-lo com obras. por outro lado, ao mesmo tempo que rejeitamos o salão, reforçamos a ideia de que a nossa articulação é importante, e merece ser vista por outras pessoas. 0 espaço material estaria sendo ocupado, ao mesmo tempo que estaria sendo negado, uma vez que o ocuparíamos apenas para divulgar 0 endereço de um espaço virtual, onde, ai sim, estaria hospedada a "obra" [.... $]^{99}$.

$\mathrm{Na}$ correspondência que consta no site com os e-mails trocados entre os Rejeitados e os organizadores do Salão - referentes às solicitações de informações padronizadas para a confecção do catálogo - fica evidente aquilo que Ricardo Rosas destacará nessas insurgências artísticas: certa procura em violar os códigos, por meio da "pura desobediência civil" (ROSAS, 2006a, p.11).

[...] temos que batalhar para não ter nada além do endereço; se ela [trata-se de Adélia Xavier] insistir no currículo, SUGIRO algo como "os rejeitados não tem currículo", se insistir na foto, "os rejeitados não tem foto e não autorizam fotografar nada do que foi enviado na inscrição", se insistir em divulgar endereço de correio e telefone, autorizados na ficha de inscrição, tudo bem, mas "os rejeitados não autorizam divulgar os nomes dos grupos integrantes [...]" (KUNSCH, 2002) 100 .

[...] viva nossa condição de rejeitados, de incatalogaveis... [...]. vamos entupir o e-mail e a caixa de correspondência deles... vamos mandar tanto papel q eles não terão onde guardar, não terão como expor... vamos aporrinhar tanto eles [...] nos mandarão sumir, vamos desprezá-los, vamos rejeitá-los..[...] (LOS VALDERRAMAS, 2002)101.

Nesse jogo de forças entre os artistas e os representantes institucionais historicamente munidos do poder de incluir ou excluir, premiar e dar visibilidade - é possível localizar um tipo de abordagem subversiva muito peculiar ao período em

98 Possivelmente, trata-se de Paulo Veiga, mencionado em outro e-mail datado de 24 de outubro, enviado por Graziela Kunsch para o grupo.

$99 \quad$ Ressalta-se que no original o grifo é em vermelho e destacado com corpo maior do que o restante do texto. Disponível em: <http://www.geocities.ws/rejeitadosnonono/[em cachê]. Acesso em: 28 mar. 2015.

100 E-mail enviado por Graziela Kunsch, em 8 de novembro de 2002 . Disponível em: <http://www.geocities.ws/rejeitadosnonono/> [em cachê]. Acesso em: 28 mar. 2015

101 E-mail escrito pelo grupo Los Valderramas, em 11 de novembro de 2002. Disponível em: <http://www.geocities.ws/rejeitadosnonono/ [em cachê]. Acesso em: 28 mar. 2015. 
questão. Trata-se daquilo que Fernando Cochiaralle denominou de sentido virótico, de invasão em "[...] sistemas codificados por normas estabelecidas para colocá-los em pane, para questioná-los em suas entranhas, pô-los em curto-circuito, ainda que por instantes" (COCHIARALLE, 2003, 2006, p.18).

A análise de Cochiaralle é pertinente para abordar como a proposta dos Rejeitados colocou em pane o sistema codificado por normas daquele Salão, "ainda que por instantes", conforme salientou 0 autor. Deve-se considerar por um lado a relação com os membros das comissões de seleção e premiação. Nesse sentido, segundo consta no artigo de Juliana Monachesi102, Luiz Camillo Osório - integrante tanto o júri de seleção quanto de premiação103 - declarou que, a decisão do júri ao aceitar a proposta dos Rejeitados, pretendia "[...] indicar o quanto ser rejeitado não cabia a eles decidir, cabia a nós" (MONACHESI, 2002). O projeto foi aceito, mas não premiado, entretanto, no texto de apresentação do catálogo, assinado por Luiz Camillo Osório, ainda que os Rejeitados não sejam explicitamente mencionados, indiretamente 0 projeto serviu de mote para a maior parte das considerações tecidas ao longo do escrito (OSORIO, 2002)104. Destaca-se, além disso, que na correspondência do grupo, Graziela Kunsch, em mensagem enviada em 24 de outubro de 2002, comentou que iria "[...] toscamente (des)ordenar e colar todos esses e-mails e fazer 3 encadernaçoes, uma para o salao, e duas para o luiz camillo e a gloria ferreira, que estavam querendo comentar o ressurgimento (???) dos grupos brasileiros" (KUNSCH, 2002).

O ruído no sistema codificado por normas, ainda que por instantes, parece ter sido mais acentuado quando analisado a partir de alguns aspectos técnicos. Como encaixar, por exemplo, "um coletivo formado por coletivos" com grupos provenientes de diversos Estados brasileiros dentro das tabelas estatísticas do Salão que figuram no final do catálogo, por procedência e faixa etária dos inscritos e dos selecionados? Se quanto à faixa etária não foi possível detectar a solução encontrada, em relação à procedência o recurso utilizado foi informar que eles eram do Rio Grande do Sul. Em diversos momentos na correspondência do grupo, eles mencionam que tinham a intenção de enviar (não fica claro nos e-mails, entretanto, se isso foi de fato efetivado) correspondências aos funcionários da instituição - "[...] estou finalmente finalizando o trabalho do after_ratos, o happening da (des)igualdade social', a carta aos espectadores, apos as mais de 70 cartas aos funcionarios e a

\footnotetext{
102 Trata-se do artigo Artes muito contemporâneas - Salões e crítica institucional.

103 Além de Luiz Camillo Osório, os participantes do júri de seleção foram: Denise Mattar, Marcus Lontra, Gilberto Chateaubriand e Heitor Reis, enquanto, a equipe do júri de premiação era formada por Luiz Camillo Osório, Gilberto Chateaubriand, Heitor Reis, Franklin Pedroso e Ricardo Ribemboim. CATÁLOGO go SALÃO MAM-BAHIA. Salvador: MAM/BA, 2002, s/p.

104 OSÓRIO, Luiz Camillo. Texto de apresentação do $9^{\circ}$ Salão da Bahia. In: Catálogo $9^{\circ}$ Salão MAM-BAHIA. Salvador: MAM/BA, 2002, s/p.
} 
carta-projeto ao júri [...]", escreveu, por exemplo, Graziela Kunsch em 20 de outubro (2002) —, porém, se isso causou algum transtorno no cotidiano de trabalho dos funcionários, foi por instantes. Dois dos integrantes da equipe de organização do $9^{\circ}$ Salão da Bahia ${ }^{105}$ foram entrevistados e ambos, somente com muita insistência, afirmaram lembrar vagamente dos Rejeitados.

Analisando as alterações ocorridas na cena artística independente nos anos iniciais da primeira década do século XXI no Brasil, Ricardo Rosas (2006) sublinhou que inicialmente, apesar da tônica irônica em relação ao circuito artístico oficial "[...] já transparecia uma atitude crítica não apenas com o meio artístico institucionalizado, mas igualmente com os critérios de valor cultural que se atribui à arte ou dita 'o que é arte"' (ROSAS, 2006, p.297). O autor ressalvou, porém, que nesse período não havia "[...] um vínculo estreito e palpável com práticas ativistas mais diretas" (ROSAS, 2006, p.297). Segundo ele, essa questão foi sendo alterada a partir de 2003, quando se intensificou a inserção política desses grupos. Nesse sentido, a organização do primeiro Congresso Internacional de A(r)rivismo, em outubro de 2003, que satirizava a utilização do termo A(r)tivista pela mídia, debatendo a cooptação desses grupos pela indústria cultural; a mobilização coletiva pelos Sem-Teto de São Paulo, realizada pelo Movimento ACMSTC (Arte Contemporânea no Movimento dos Sem-Teto do Centro) ${ }^{106}$, em dezembro do mesmo ano; a ação na Favela do Moinho, em São Paulo, em 2004107, foram alguns dos exemplos destacados por Ricardo Rosas. Por outro lado, o autor apontou para uma diversificação dessas

105 A equipe era formada por três membros: Adélia Xavier, Luiz Cristiano Paraguassú e Maria Cecília Oliveira. Foram os dois últimos que foram entrevistados pela autora, via Skype, em 01 de setembro de 2015. Ressalta-se, que ambos destacaram que o contato direto com os artistas era incumbência de Adélia Xavier.

106 Uma análise detalhada dessa e outras ações subsequentes no processo de colaboração entre artistas, coletivos artísticos e Movimento Sem-Teto do Centro (MSTC] em São Paulo, entre os anos de 2003 até 2007, foi realizada por Sebastião Oliveira Neto. Cf. OLIVEIRA NETO, Sebastião. Situação Prestes Maia: o processo de colaboração entre artistas, coletivos artísticos e o Movimento Sem-Teto do Centro (MSTC). Ocupação Prestes Maia/São Paulo (2003-2007). 2012. Dissertação (Mestrado Interunidades em Estética e História da Arte) - Universidade de São Paulo, São Paulo, 2012.

107 Segundo Sebastião Oliveira Neto, a ação na Favela do Moinho, foi uma rearticulação dos coletivos de arte que participaram do ACMSTC, em 2003. Parte da área, localizada entre as estações Luz e Barra Funda do metrô, ocupada inicialmente por moradores de rua e por uma comunidade, foi utilizada em 1997, pelo projeto Arte/Cidade. Segundo o autor, os moradores foram expulsos do local para a realização do evento, retornando após seu término. Tentando estabelecer uma articulação de aproximação, oposta à empreendida pelo Arte/Cidade, os organizadores dessa nova empreitada articularam reuniões com a pastoral católica e pessoas do narcotráfico, até conseguirem autorização para a realização do evento em um final de semana. Um dos trabalhos realizado pelo Coletivo Esqueleto, "que instalou um tecido vermelho de 40 metros de comprimento encima do moinho, que caia sobre a favela como uma grande língua vermelha, como uma grande bandeira de guerra [...]. Alguns moradores se incomodaram com o tecido temendo que ele fosse confundido com algum estado de alerta enviado pelo PCC (Primeiro Comando da Capital), iniciado em 1993, sendo uma das maiores organizações criminosas do Brasil e mandaram que fosse retirado imediatamente, e assim foi" (BORGES, 2006, p.85). Conforme pontuou Oliveira Neto, as contradições e os riscos, no caso da Favela do moinho, eram diversos do movimento social do MSTC: "dominada por grupos ligados ao narcotráfico, o clima era bastante tenso e as pessoas não eram tão abertas à participação [...] em meio a esses riscos, obstáculos, questionamentos e contradições, teve fim mais uma ação que propunham aproximar a produção artística de uma comunidade marginalizada" (2012, p.89). BORGES, Fabiane Moraes. Domínios do Demasiado. 2005. Dissertação (Mestrado em Psicologia Clínica) - Pontifícia Universidade Católica de São Paulo, São Paulo, 2006. 
práticas coletivas que, em uma multiplicidade de abordagens em um período mais recente ${ }^{108}$, mesclando tanto "[...] a questão urbana propriamente dita (sua invasão ou 'expulsão') quanto às implicações políticas ou o inusitado estético" (2006, p.299), correndo, em alguns casos, um sério risco, porque a mensagem política não possui nitidez suficiente, sendo pouco perceptível: "'Coletivo' agora é uma moda, e como tal, passou a fazer parte do catálogo de estratégias dos executivos de marketing de grandes empresas", enfatizou o autor (2006, p.299)109. A partir desse contexto em alteração, Ricardo Rosas discutiu comparativamente, as ações de transversalidade desenvolvidas por grupos no exterior que defendem com muita clareza suas posições de contestação ${ }^{110}$ com muitos dos coletivos brasileiros. Assim, o autor fez as seguintes indagações:

Mas por que essa falta de asserção em muitos coletivos brasileiros? Acaso não haverão [sic] causas, questões, problemas candentes em nosso país? Por que muitas vezes a diversão supera a seriedade do que é tratado, se é que é tratado? Será mesmo da natureza brasileira um caráter festivo e indiferente, ou será uma falta de maturidade dos grupos? (ROSAS, 2006, p.301).

Ao expor o enfretamento ao $9^{\circ}$ Salão da Bahia realizado pelos Rejeitados, em conjunto com o panorama e as questões levantadas por Ricardo Rosas em relação aos coletivos, é possível pensar que essas articulações mais contestatórias foram, sobretudo, pontuais no caso brasileiro. Dessa forma, com algumas ressalvas, a relação dos coletivos capixabas Maruípe e Entretantos com as instituições pode ser compreendida mais como regra do que como exceção. Conforme pontuou André Mesquita $(2008)^{111}$, a "[...] atitude que se sobressai no discurso dos coletivos brasileiros é a sua inserção no sistema institucional como 'brecha', como um vírus que pode contaminar e mudar o circuito de arte por dentro" (2008, p.251). Esse discurso, muitas vezes ambivalente, detectado tanto por Mesquita (2008)

108 Ao que tudo indica, o texto aqui utilizado foi escrito em 2005 para uma palestra ministrada pelo autor na Mesaredonda Campos independentes: coletivos, ativistas e comunidades digitais, para o Simpósio Padrões aos Pedaços: o pensamento contemporâneo na arte, realizado no Paço das Artes em São Paulo, entre 7 e 10 de agosto de 2005.

109 Para exemplificar, a absorção de coletivos pelo viés publicitário, Rosas menciona "festivais elaborados por empresas como a Skol, Nokia ou Tim" (2006, p.299). Em momento posterior do texto, Rosas indagou o porquê do interesse dos planejadores de campanhas publicitárias em incorporarem esses coletivos, cujas ações nos espaços públicos possuíam a pretensão de contestar os valores dominantes. Em uma tentativa de resposta, o autor afirmou: "Minha hipótese aqui é que isso se deve em parte a uma falta de clareza nas propostas, à ausência de uma assertiva que evidencie o motivo tratado, 0 que está sendo defendido, o problema abordado." Em resumo, trata-se do que o autor denominou de uma "indeterminação de foco" (ROSAS, 2006, p.300).

$110 \quad$ Sobre os grupos no exterior, o autor fez a seguinte afirmação: "Agindo transversalmente em ações que misturam mídia e ativismo, arte e tecnologia, ou performance e produção (ou modificação) de artefatos ou dispositivos, a maior parte destes coletivos defendem suas posições com muita clareza, seja para contestar os parâmetros atuais da biotecnologia e transgênicos, como no caso do Critical Art Ensemble (EUA), seja na defesa da ideologia do uso e da criação aberta, como o Superflex (Dinamarca) ou o De Geuzen (Holanda), que se baseiam nas comunidades do software livre e open source, seja na contestação (e paródia) das grandes corporações, como se dá com o Yes Men (EUA) [...], seja com o trabalho com comunidades desfavorecidas e serviço social, como os membros do Wochenklausur (Alemanha), entre outros caso. Na fronteira entre arte e ativismo, tais grupos realizam ações de impacto público que ao mesmo tempo circulam no meio artístico ou são vistas como arte" (ROSAS, 2006, p.300-301).

111 MESQUITA, André Luiz. Insurgências poéticas: arte ativista e ação coletiva (1990-2000). 2008. Dissertação (Mestrado) FFLCH/USP, 2008. 
quanto por Albuquerque (2006), não foi a tônica desses dois coletivos do Espírito Santo. Dessa forma, ao assumir - implícita ou explicitamente - 0 desejo de inserção no sistema das artes, esses grupos capixabas, adotaram uma postura mais coerente do que daqueles que simularam um antagonismo, não raro inócuo, tímido, ambíguo ou sem clareza. Porém, considerando os diálogos possíveis no contexto local, cabe indagar se haveria alternativa diversa para esses dois grupos capixabas senão a que foi adotada.

Uma possibilidade de resposta pode ser aventada retomando comparativamente as sinas dos e-mails trocados entre os Rejeitados e a correspondência do grupo de discussão do Paralela-ao-mar, a partir de dois termos: ruído e silêncio. 0 primeiro despertou interesse de membros da comunidade artística mesmo quando suas ações ainda estavam em curso - conforme pode ser detectado na solicitação de encadernações com suas discussões por Camilo Osório e Glória Ferreira -, tendo ainda, o registro de suas ações no catálogo do $9^{\circ}$ Salão da Bahia - por meio do endereço do site com as mensagens trocadas entre seus integrantes -, bem como, publicações da imprensa de repercussão nacional sobre as ações por eles conduzidas impulsionaram outras discussões. Diversamente, ao grupo capixaba restou deixar o registro de suas mensagens por meio de seus próprios canais de divulgação - cabe recordar o desalento expresso por Elaine Pinheiro em relação à ausência de divulgação da ação promovida na imprensa local —, além da discussão integrar o trabalho Olhar para ela proposto por Rafael Corrêa (membro do Coletivo Maruípe). Neste, a correspondência do grupo foi impressa e as folhas transformadas em barquinhos de papel que, seriam lançados "[...] pelos mares da cidade [...] para que por via desses as adentre todas as terras banhadas por água [...]". Enfim, concluiu o artista: "[...] é preciso jogar os pensamentos nas águas para que as ondas os retornem em direção à cidade" (CORRÊA, 2004). A tentativa de quebrar o silêncio e provocar ruídos não aparece apenas no sentido figurado. Em 16 de dezembro de 2004, dia da abertura do Salão Capixaba do Mar, o coletivo inaugurou seu próprio evento em construção defronte à sede do evento oficial, denominada de Casa da Cultura ${ }^{112}$. Informando, no grupo de discussões, sobre as ações do coletivo nesse dia, Meng Guimarães (integrante do Coletivo Maruípe), afirmou: "Os barcos do Rafael fizeram sucesso e a

112 O prédio foi construído no final da década de 1970 pela UFES para funcionar como restaurante universitário. Porém, foi demolido no final dos anos de 2000 , sendo que a área passou a servir como estacionamento. No período em que - Coletivo Maruípe realizou o Paralela-ao-mar, a ocupação da Casa da Cultura estava sendo alvo de discussões acirradas entre a UFES, a comunidade da região e um grupo de artistas denominado de Palca (Projeto de área Livre de Cultura e Arte). Os integrantes deste último grupo, segundo consta em reportagem da época, declararam que o local era ponto de convergência da produção cultural autônoma do Estado. Mencionando uma fala atribuída à Fabíola Melca (integrante do Palca), consta que ela declarou: "A proposta é integrar cultura e política. Acreditamos que tudo está interligado. É importante realizar atividades tanto na área de arte - música, dança, teatro, artes visuais, artes plásticas - quanto na formação política por meio de cursos e oficinas para fomentar o debate de espaços públicos de cultura". Disponível em: $<$ https://br.groups.yahoo.com/neo/groups/paralelaaomar/conversations/topics/140>. Acesso em: 10 out. 2016. 
conversa de guitarras ${ }^{113}$, idealizada pelo sil, atraiu ou pelo barulho (mal interpretado) ou pela música (experimental)" (GUIMARÃES, 2004).

\subsection{2 - Desafio e descrença}

Nesse sentido, pode-se voltar às intervenções do Cine Falcatrua, pois este coletivo executou eventos de modo peculiar quando comparado aqueles dois outros grupos que the são contemporâneos em Vitória. O coletivo lança mão da ironia para questionar o modelo da cadeia artística corrente, a qual, embora simule seguir a cartilha imposta pelo padrão de eventos, reiteradamente, irá questioná-la. Descrença e desafio permeiam as diretrizes dos eventos empreendidos pelo grupo desde seu aspecto conceitual até sua premiação e, diferentemente do Maruípe e, sobretudo do Entretantos, ao sublinhar a importância e pioneirismo de suas ações para o debate cultural da cidade, o Cine Falcatrua parece saber ou intuir que, na virada do século XXI, diante de toda a revolução no acesso à informação, mais urgente do que impor uma narrativa é discutir os meios de se obter autonomia diante das informações.

No ano de 2005, no mês de maio, o coletivo participou do II Festival do Olhar Livre Creative Commons (Flô), em Porto Alegre (RS), com a Mostra Falcatrua de Conteúdos Livres. Foi o início de uma série que transitou tanto em Vitória e algumas cidades do interior do Espírito Santo, quanto em eventos dedicados a discutir o software livre no Brasil e no exterior. As produções exibidas mesclavam gêneros diversos, abarcando desde produções experimentais - algumas de autoria do próprio Cine Falcatrua - até episódios do seriado televisivo Chaves. Na programação, como em outras ações do grupo, além da projeção dos filmes, eram distribuídas cartilhas com instruções para a montagem de exibições utilizando equipamentos improvisados. O objetivo era debater a relação "[...] entre tecnologias digitais e produção cinematográfica, oferecendo uma vitrine transparente do poder que a Internet pode fazer para o audiovisual atingir seu termo — isto é, o público" (FALCATRUA, 2006) ${ }^{114}$.

No evento Agosto no Cinema, na edição de 2005, o coletivo solicitou para quatro cinéfilos do Espírito Santo a seleção de um filme que tenha marcado suas histórias de vida. No dia da exibição, um texto escrito pelo convidado era publicado no caderno cultural de um dos jornais locais de maior circulação no Estado, $A$ Gazeta. Após o término da sessão, plateia e cinéfilo se deslocavam para um bar, "[...] onde curador e público se encaram de igual para igual" (FALCATRUA, 2005). A intenção era

\footnotetext{
113 Trata-se do trabalho Canhão - corpo, cabo e cubo de Silfarlem Júnior de Oliveira. A performance foi resumida da seguinte forma: "calçada em frente à casa da cultura - esquina da av. jerônimo monteiro com r. governador josé sette, quinta à noite, dia 16 de dezembro.performance sonora utilizando caixas de som dispostas em círculo, viradas umas para as outras, e pessoas que se deslocam tendo como limite cabos, comunicando-se através de instrumentos musicais". Disponível em: <http://www.maruipe.blogger.com.br/>. Acesso em: 12 abr. 2017.

114 Disponível em: <https://cinefalcatrua.wordpress.com/category/mas-heim/<. Acesso em: 20 jun. 2015.
} 
"converter a tradicional prática cineclubista de 'debater o filme', forçando-a aos seus dois extremos: 0 discurso unilateral do expert e a saudável balbúrdia apaixonada", conforme foi descrito em publicação do coletivo (FALCATRUA, 2006, grifo do autor) ${ }^{115}$. Além dos propósitos expostos pelo grupo, eventos como esse ajudavam a angariar a simpatia de públicos diversificados, fornecendo maior visibilidade ao projeto e consolidando suas atividades por meio de estratégias diversificadas.

No segundo semestre de 2005, o Cine Falcatrua organizou seu próprio festival competitivo de vídeos, intitulado I Festival de Baixa Resolução, o evento - realizado em um bar no Centro de Vitória - ocorreu paralelo ao $12^{\circ}$ Vitória Cine Vídeo ${ }^{116}$. Como outras iniciativas do período ${ }^{117}$, o coletivo dialogou de forma irônica com o evento de infraestrutura de maior porte: parodiando as estratégias midiáticas do $12^{\circ}$ Vitória Cine Vídeo (Fig. 05), bem como, as distinções de infraestrutura entre os dois festivais. Para tanto, simularam expor os bastidores do Festival de Baixa Resolução, evocando pelo avesso o que não possuíam (como assessoria de imprensa e auxiliares que sistematizassem os inúmeros vídeos recebidos), acrescentando ainda as incongruências presentes nos empreendimentos do período, afirmando que dispunham de um setor que não fez nada e que só foi adicionado por estar na moda. Trata-se do que eles denominaram de "Logística de responsabilidade socioambiental para o desenvolvimento regional sustentável", isso porque "não existe empreendimento sério e responsável sem essas palavrinhas genéricas e mágicas" (FALCATRUA, 2005). É necessário ressaltar que a postagem citada foi feita para informar sobre a demora na divulgação dos resultados do Festival de Baixa Resolução. Assim, o coletivo recorre à autoironia, em sentido semelhante a um dos exemplos

\footnotetext{
115 Disponivel em: <https://cinefalcatrua.wordpress.com/category/mas-heim/>. Acesso em: 20 jun. 2015.

116 Em 2005, o evento aconteceu entre os dias 28 de novembro e 03 de dezembro. Trata-se de um festival anual iniciado em 1994 na cidade de Vitória. A partir de 1997, passaram a promover mostras competitivas nacionais de vídeos de curta e média metragem. Os vídeos vencedores, divididos em dezenove categorias, recebiam o Troféu Marlin Azul. A denominação do troféu faz referência a um peixe de grande porte que é abundante na costa capixaba. 0 Cine Falcatrua, no Festival de Baixa Resolução, criou o grande Troféu Sardinha Sagaz que o vencedor ganharia em conjunto com uma grade de cerveja. Deve-se ressaltar que alguns integrantes do coletivo, também participaram da $12^{\mathrm{a}}$ edição do Vitória Cine Vídeo. As produções Compondo Sobre uma Tela, de Fabrício Noronha (integrante do Cine Falcatrua) e David Caetano, TV Falcatrua, de Gilbertinho (personagem criado como codinome do grupo) e O Gilbertinho Prefere Cópias Digitais, de Gabriel Menotti, foram selecionadas pelo evento.

117 Diversos eventos realizados pela Casa da Xiclet servem para exemplificar essas apropriações. A Casa, um híbrido de residência e galeria, localizada no bairro da Vila Madalena em São Paulo, foi criada pela artista capixaba Adriana Duarte. As exposições tiveram início em 2001, muitas das quais, passaram a adotar "o próprio circuito 'oficial' das artes e seus 'conceitos' como material de trabalho". Dois exemplos, das inúmeras paródias realizadas como respostas ao circuito, são: a $27^{a}$ Bienal da Casa da Xiclet "Como Viver Longe" (o nome do evento oficial era "Como viver junto") e a Bienal: Tô Cheia (em referência à Bienal do Vazio, forma como ficou conhecida a $28^{\circ}$ Bienal de São Paulo). Disponível em: $<$ https://casadaxiclet.com/todasexposcoesallexhibitions/>. Acesso em: 08 nov. 2016.
} 
mencionados por Vilém Flusser relativos à forma de ironia utilizada pelos judeus nos tempos do nazismo: "Barco a remo judeu afunda cruzador alemão" (FLUSSER, 2008)118.

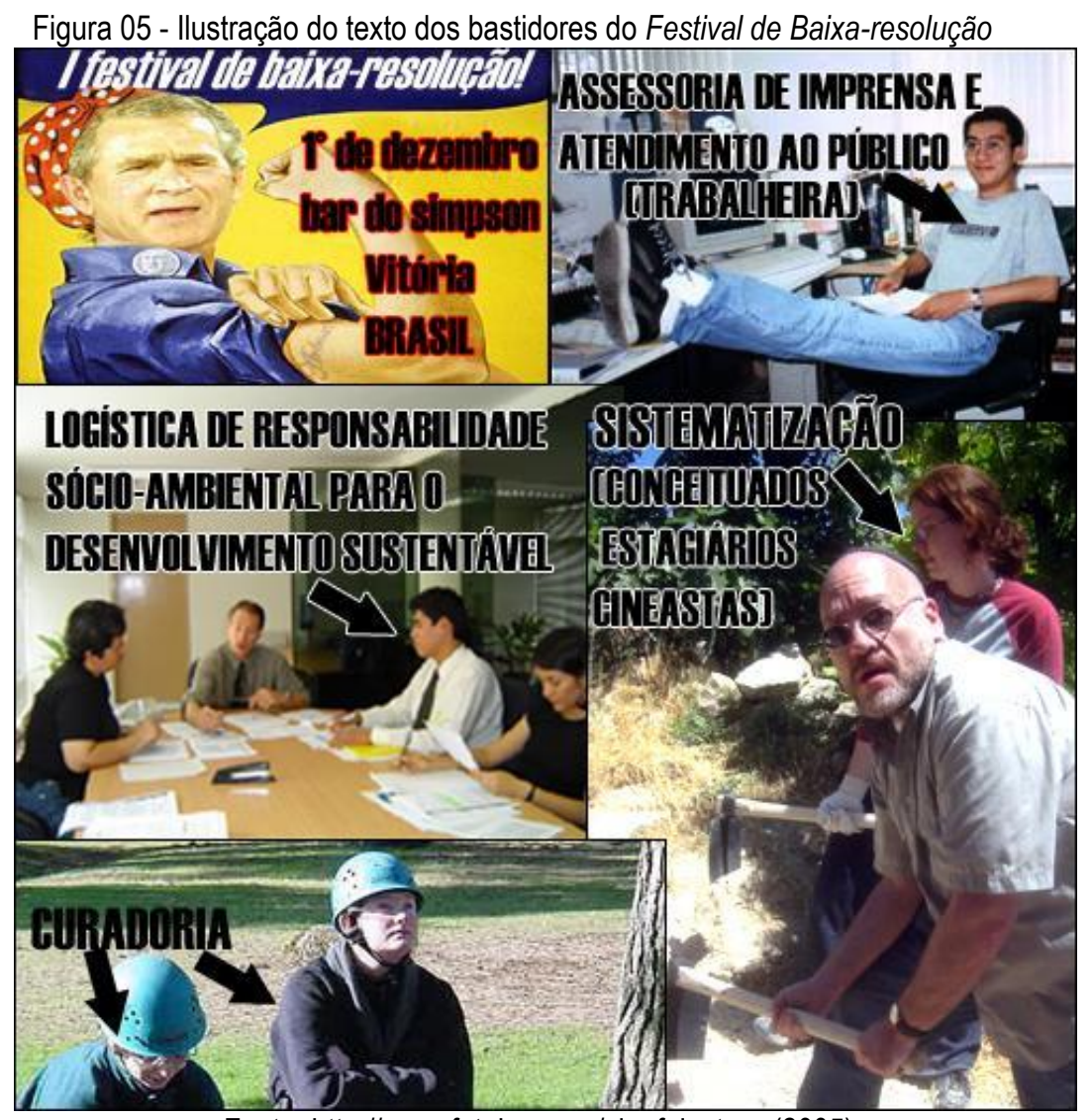

Fonte: http://www.fotolog.com/cinefalcatrua (2005).

O Festival de Baixa Resolução foi definido pelo grupo como o primeiro festival de não realizadores do mundo, uma vez que os competidores não precisavam ser autores das obras inscritas, cabendo a eles somente enviar vídeos encontrados na Internet, não importando o conteúdo, ano de produção, duração, gênero, inclinação ideológica, resolução, com ou sem áudio, e até mesmo sem imagem ${ }^{119}$. A forma de envio era uma das poucas limitações, uma vez que deveria ser realizada pela Internet e, portanto, em baixa resolução por conta da velocidade, conforme o título do festival aponta. 0 prêmio prometido no regulamento era um troféu e um engradado de cerveja, em momento posterior, os

\footnotetext{
118 FLUSSER, Vilém. Da Ironia. Publicado originalmente na Folha de S. Paulo, em 26-02/1972. Este e outros textos do autor foram disponibilizados, em 2008, no seguinte endereço. Disponível em: <http://textosdevilemflusser.blogspot.com.br/2008/08/da-ironia.html>. Acesso em: 08 nov. 2016.

119 Conforme constava no regulamento "Para participar, o vídeo tem ser encontrado na Web e somente na Web. Pode ser conteúdo original ou alterado, hypes audiovisuais, caps de programas de tv suburbanos, animações em flash, montagens com videogame, videoclipes toscos, paródias, redublagens ou o Willian Bonner imitando o Clodovil". Todavia, alguns enviaram trabalhos autorais e foram aceitos, conforme foi informado pelos integrantes do coletivo na entrevista à rádio universitária. Disponível em: <http://www.fotolog.com/cinefalcatrua/12718803/>. Acesso em: 04 ago. 2016.
} 
integrantes do coletivo informaram que concederam também um "prêmio residência" na casa de um dos membros do coletivo, entretanto, o vencedor nunca requisitou o seu prêmio ${ }^{120}$.

Ao lançarem as normas de participação, em 16 de outubro, o coletivo pediu que os interessados prestassem atenção ao regulamento, pouco depois em outra chamada, eles resumem em poucas linhas do que trata o texto para aqueles que "[...] tem preguiça de ler regulamentos" (FALCATRUA, 2005), indagando em postagem subsequente, "alguém lê regulamentos?" (FALCATRUA, 2005).

O pressuposto contido na pergunta acima - que são poucos aqueles que prestam atenção em todas as normas que compõem os regulamentos - pautou as chamadas para a participação no Festival CortaCurtas ${ }^{121}$. Ainda que constasse a informação que caberia ao projetista a seleção do que e como seriam mostrados os trabalhos enviados, a ênfase recaia no fato de que todo o material recebido entraria na programação do projeto Rumos Artes Visuais 2005-2006 do Instituto Itaú Cultural. Segundo declararam os integrantes do coletivo, no edital de divulgação com letra em corpo menor que o restante das informações, constava que eles exibiriam como bem entendessem os filmes recebidos ${ }^{122}$.

Além dos recortes e colagens, tanto no áudio quanto nas sequências de imagens, o coletivo também inseriu diversas logomarcas em um dos filmes recebidos que foi descrito como tosco, porém, muito bom, denominado Os beijos que não te dei... A exibição deste filme na íntegra, em uma das sessões, foi questionada pelo realizador de outra produção que só foi contemplada com um trecho do áudio. Ele interpelou o grupo sobre o motivo de destacar uma obra que, considerando a importância dos patrocinadores, não prescindia do mesmo incentivo que um trabalho como o dele, feito sem recursos. Essa reação, para o coletivo, é representativa da discussão que eles pretendiam: problematizar a agressividade velada que rege as hierarquias, premiações e juízos de valor sobre

120 A informação consta na entrevista concedida pelo grupo à rádio universitária, em 2013. Ressalta-se que ao mencionarem o "prêmio residência" os integrantes do coletivo ironizam as condições que seriam ofertadas, induzindo o ouvinte a perguntar: quem poderia se interessar por obter como "prêmio" ficar em uma república de estudantes? De forma diversa, o coletivo Entretantos no multipliCIDADE (2007) ao divulgar a possibilidade dos participantes de outros Estados ficarem alojados no apartamento de uma "querida amiga", informam aquilo que é presumível: as condições modestas de acomodação. "Neste ano o multipliCIDADE terá um espaço que poderemos chamar de 'Residência Artística' [...] Será um espaço destinado aos participantes de outros estados que desejam ficar num lugar simples, com estrutura básica de acomodação..." O texto, ilustrado com seis imagens de uma residência estudantil convencional, é acompanhado pela legenda "Imagens da Residência Artística no InterUrbanos, em Fortaleza - CE, em agosto de 2007". É possível detectar no material do Entretantos um receio em criar falsas expectativas e informar com precisão protocolar questões que poderiam ser omitidas, considerando o público ao qual o evento era endereçado (multipliCIDADE 2007). Ver, respectivamente: Disponível em: <http://www.universitariafm.ufes.br/sites/default/files/audio/revista_universitaria_23-01-13.mp3 >. Acesso em: 14 dez. 2014. Disponível em: <http://www.multipliCIDADE2006.com>. Acesso em: 08 out. 2013.

$121 \quad$ Conforme já foi exposto, o Festival CortaCurtas foi decorrente da seleção do Falcatrua no projeto Rumos Artes Visuais 2005-2006, promovido pelo Instituto Cultural Itaú.

122 O regulamento completo e a ficha de inscrição estavam disponíveis na página do Itaú Cultural, porém, o link já foi retirado. <http://www.itaucultural.org.br/index.cfm?cdl_pagina=2564>. Acesso em: 20 mai. 2017. 
obras e pessoas, existentes nos festivais. Agressividade também presente na própria forma do grupo seduzir os participantes a partir da noção que não haveria seleção. Assim, a colaboração resultante dessa relação beneficiava, sobretudo, o próprio coletivo ${ }^{123}$. O CortaCurtas funcionou como uma emulação da fórmula dos grandes eventos e outras ações que, beneficiadas pelas Leis de Incentivos Fiscais, passaram a utilizar a área da cultura e das artes como marketing simbólico para divulgação empresarial, operando, assim, uma crítica sutil ao circuito oficial.

As premissas ostentadas por esses coletivos na elaboração de seus eventos diante do circuito instituído, procurando rearticular domínios, traçando outras possibilidades e redesenhando fronteiras, talvez seja menos empolgante quando examinada para além do esforço utópico empreendido. Se por um lado, a tentativa do Coletivo Maruípe de realizar um evento fora dos padrões estabelecidos pelo cenário artístico local, em que um ideal imaginário mirava a construção de um evento coletivo de fato, embora com produção predominantemente individual, não se mostrou autossustentável, por outro, o Coletivo Entretantos e o Cine Falcatrua enveredaram pela estrada pavimentada dos protocolos dos eventos oficiais, embora com distinções fundamentais em suas abordagens. Especificamente no caso do Entretantos, a réplica crente do modelo instituído, longe de refletir em repulsa, gera a reafirmação e revalidação do paradigma com a mera renovação dos seus protagonistas. No segundo caso, mesmo que o Cine Falcatrua tenha utilizado os mesmos protocolos padronizados pelo sistema artístico vigente, o fez de maneira por vezes irônica ou mesmo ambígua. Isto é, a promoção de exibições não autorizadas de audiovisual, a instrução sobre os procedimentos de acesso digital, o debate entre cinéfilo e público em um bar, a entrega de um engradado de cerveja como premiação do festival, a realização de making of de uma produção precária, o fornecimento de edital resumido a participantes desatentos e a apropriação de obras alheias como material para um novo trabalho são alguns dos muitos mecanismos utilizados pelo grupo para contrapor o status quo. É assim que o coletivo contestou a legislação de direitos autorais, o papel da educação e esclarecimento para a autonomia do indivíduo e não apenas para imposição de uma prática artística hegemônica, dos ambientes cabíveis à discussão artística, confrontando o valor simbólico e prático das premiações, questionando a eficácia da estrutura desses eventos, minimizando a relevância da precisão do regulamento e, finalmente, frustrando a vitória dos contemplados pelos processos de seleção, respectivamente, em um procedimento de descrença e descrédito dos rituais consagrados pelo circuito. Seus integrantes, portanto, admitem fazer parte do sistema, vínculo inevitável como estratégia de sobrevivência, mas confrontam-no em distintas oportunidades.

\footnotetext{
123 As informações foram retiradas da entrevista concedida à rádio universitária da UFES, por alguns dos integrantes do Cine Falcatrua em 24 de janeiro de 2013.
} 


\subsection{RELAÇÕES: COLETIVO PARA ALÉM DOS SEUS INTEGRANTES}

A cultura de interação estabelecida pelos coletivos com seu público é um importante indício de continuação ou quebra com o padrão instituído pelos corpos oficiais que a cena "independente" pretendia suplantar. Da abertura e tentativas de estabelecer ideais democráticos, ao controle e resguardo hierárquico, os coletivos desenvolveram estratégias de socialização, comunicação, partilha e colaboração, diferenciadas para a execução de suas atividades. Se, por um lado, a disponibilidade e liberdade podem levar à inviabilização de ações reais, por outro, o fechamento e direcionamento, embora produtivos, resultam em espelho da conduta empreendida pelas instituições "dependentes". Assim, embora haja a insatisfação, velada ou explícita, diante da lógica estabelecida pelo modelo oficial, a solução apresentada pelos grupos pode se revelar ineficaz, pois centram esforços na criação de novas instituições e falham por não renovar o modelo em vigor. O Coletivo Maruípe, dentre os três grupos analisados, fornece o melhor exemplo de tentativa de implementação de uma conduta antagônica ao regime institucionalizado. Em entrevista, Elaine Pinheiro, uma das integrantes do grupo, declarou que as atividades de bate-papo no ateliê eram abertas ao público em geral (ALBUQUERQUE, 2006, p.182), ainda que não tenha mencionado a mesma abertura em relação à utilização do espaço ateliê em si124. Igualmente acessível a qualquer interessado, o grupo de discussão Paralela-ao-mar'125 do coletivo, idealizado como ponto de debate para a realização de evento sob o mesmo nome, tinha acesso irrestrito aos interessados em participar tanto das discussões quanto do evento em si. Com o fórum aberto à participação, o coletivo experimentava um comportamento diferenciado do praticado pelas instituições oficiais locais, pois a proliferação de contatos empolgava, estimulava e impulsionava ao mesmo tempo em que causava ruídos e incômodos. Como exemplo, a reação dos integrantes do grupo de discussão à publicação de uma postagem com pedidos de voto de participante das discussões que era candidato em um concurso de arte é simplesmente a de ignorá-lo:

Você pode ver aqui a pintura acrílica sobre tela 'Bule' $<$ <ttp://www.pitturaedintorni.it/concorso.asp>, de minha autoria (Reginaldo Leite).

Se gostar, vote nela para vencer o concurso italiano 'La Tela del Mese'. Conto com o seu voto, marcando o meu nome e clicando em VOTAR. Até 31.01.2005 você pode votar todos

\footnotetext{
124 O compartilhamento de espaços, em maior ou menor escala, foi uma prática difundida no período, Graziela Kunsch, por exemplo, entre 2001 e 2003 abriu sua casa como residência pública de artistas, denominando a ação de Casa da Grazi. Sua biblioteca pessoal também foi disponibilizada para utilização pública, mediante agendamento de visitas a sua residência ou na ocasião de sua participação em exposições. Disponível em: <http://www.iea.usp.br/pessoas/pastapessoag/graziela-kunsch>. Acesso em 20 mai. 2017.

125 Sob a url: <http://br.groups.yahoo.com/group/paralelaaomar/>
} 
os dias, respeitando um intervalo de 24 horas. Sua atenção será muito importante, e desde já agradeço (LEITE, 2005) ${ }^{126}$.

Este meu trabalho de arte carrega um discurso que revisita os movimentos cubista e neoconcretista, incorporando uma tendência contemporânea que busca a interação com 0 expectador ${ }^{127}$. Duas linhas verticais traçadas com os olhos revelam o objeto representado o 'Bule'. Lembro que quem gostar pode votar em Reginaldo Leite diariamente,

$<$ http://www.pitturaedintorni.it/concorso.asp>

até 31.01.2005 - e eu agradeço.

$[\ldots]$

PS - 'Bule', dentre as 12 obras concorrentes, está colocada em segundo lugar, no momento. (10-01-2005) (LEITE, 2005) 128 .

Outras postagens causam desconforto explícito aos participantes do grupo de discussão. A publicação de uma propaganda ao estilo esquema em pirâmide ${ }^{129}$ - típica em fóruns, chats, listas de discussão e e-mails - realizada por um usuário identificado como padre_joel2003, com o título paralelíssima ${ }^{130}$, provoca reações vigorosas de desconforto ${ }^{131}$, enquanto outra mensagem ${ }^{132}$, desta vez de autoria de Rafael Correa, membro do grupo, é acompanhada de reclamação de um dos integrantes ${ }^{133}$. Portanto, a falta de controle das intervenções no grupo de discussão, seja como tentativa deliberada de provocação dos próprios membros ao transpor a prática artística no espaço urbano para o espaço de debate daqueles que as executavam, ou como interferência de membros alheios, configuram perturbações pouco toleradas no âmbito interno do Coletivo Maruípe.

Já o Entretantos manteve um blog para o evento multipliCIDADE versão $2006^{134}$, uma homepage para o grupo ${ }^{135}$ e uma comunidade no Orkut ${ }^{136}$. Todavia, a política de gerenciamento dava menos espaço para atuação livre dos usuários, funcionando mais como vitrine para as ações do grupo

126 Disponivel em: <https://br.groups.yahoo.com/neo/groups/paralelaaomar/conversations/messages/160>. Acesso em: 10 abr. 2017.

${ }_{127}$ Cabe sublinhar que neste, como nos demais textos escritos por e-mail, foi mantida a escrita do artista, sem a utilização do Sic. Possivelmente, por um erro de digitação, a palavra espectador foi grafada com x e não com s, como seria correto para o sentido pretendido pelo autor.

128 Disponível em: <https://br.groups.yahoo.com/neo/groups/paralelaaomar/conversations/messages/162>. Acesso em: 10 abr. 2017.

129 Ver: https://pt.wikipedia.org/wiki/Esquema_em_pirl\%C31\%A2mide.

130 Disponivel em: <https://br.groups.yahoo.com/neo/groups/paralelaaomar/conversations/topics/163>. Acesso em: 10 abr. 2017.

$131 \quad$ Fábio responde: "virou feira isso aqui?!? me dá então um kilo de tomates pra jogar nesse otário!!! :-"; enquanto Nenna: "tá estranho... socorro sil, elaine, coletivados... socorro." (11-01-2005); por sua vez, Elaine Pinheiro: "tá foda... mas por se tratar de um e-grupo totalmente aberto, estamos sujeitos a esse tipo de spam ou pirataria." (12-01-2005).

${ }_{132} \quad$ A proposta das mensagens era a de repostar antigas mensagens com anexos

133 Thiago Moulin escreve "sou só eu q recebo esses arquivos antigos ou é todo mundo? ou sou eu que tô viajando e esses arquivos são novos??? alguém me ajude..." [01-02-2005]; Elaine Pinheiro explica: "pessoal, essa é uma espécie de apologia da repetição, proposta pelo rafael corrêa. pelo visto, está realmente conseguindo incomodar...o mar regurgita e traz novamente à tona olhar pra ela." [03-02-2005].

${ }_{134} \quad$ Sob a url: http://www.multiplicidade2006.blogspot.com.br/.

135 Sob a url: www.entretantos.tk/.

136 Sob a url: http://orkut.google.com/c19305206.html. 
e plataforma de informações aos usuários interessados do que canais para franco embate. Esta conduta está mais próxima das ações institucionalizadas em sua assepsia, portanto.

Não apenas a política de comunicação dos coletivos entre seus participantes é capaz de evidenciar a eficácia positiva ou negativa das contraposições alardeadas em discursos contra o status quo, mas também a tentativa de interação das obras com esse público, assim como o objetivo da realização dos seus eventos. De espectador a participante-autor, no primeiro caso, e, do aspecto pedagógico à perturbação dos sentidos, no segundo, os grupos variam da generosidade abnóxia à altivez exacerbada.

As tentativas de alteração no estatuto da autoria no campo artístico, tensionado sua verticalidade tradicional em torno dos múltiplos aspectos que envolvem a dimensão social de participação são questões que, para Alexander Alberro (2011) - conforme já foi exposto - provocaram uma mudança sísmica no campo das artes, desencadeando alterações na forma que a arte passou a tratar seu espectador. Essa investida que entrou na ordem do dia na produção artísticas das últimas décadas foi acompanhada, em diversas ocasiões da saída do espaço expositivo convencional. Nesse sentido, ações no espaço público figuram como um componente importante por ampliar seu espectro de atuação, constituindo um lugar privilegiado, no qual, a noção anterior de "público" como "espectador" pode ir além. Capturado em seu habitat natural e alçado à posição de coautor da obra (conforme é mencionado em algumas declarações), em ambiente desprotegido das convenções usuais da arte, esse coautor, quase sempre anônimo e involuntário, figura como componente imprescindível, em uma espécie de novo material constituinte das obras. Este modus operandi, embora discutível, tem sido utilizado e exaltado como um benefício para o espectador, sendo vinculado à ideia de democracia, participação e coletivismo, ou, em alguns casos, como auxílio cognitivo ao transeunte desinformado. Um exemplo da noção de generosidade do artista para com o espectador ao dividir a autoria de sua obra, pode ser detectado na declaração do Grupo de Interferência Ambiental (GIA), que consta na publicação das ações realizadas pelo projeto multipliCIDADE, em 2006:

\footnotetext{
É nesse momento que uma guerrilha cultural se faz necessária: é preciso democratizar o alcance às práticas artísticas; a arte não pode ficar restrita a uma elite intelectualizada dentro dos sistemas oficiais de cultura. Assim, as ações independentes, ao valorizar os processos coletivos, em que o público torna-se coautor dos trabalhos artísticos, estão chamando atenção para as novas tendências contemporâneas e rompendo com concepções artísticas caducas, enaltecendo um processo que é, segundo Júlio Plaza, 'crítico ao estatuto propriedade da arte, ou seja, à cultura como prática econômica, e que propõe a informação artística como processo e não como acumulação' (GIA In: SANTOS; TEIXEIRA, 2006, p.36, grifos meus).
}

Por melhor que sejam as intenções por detrás dessa modalidade de partilha da autoria com os cidadãos desavisados, o fato de estes coautores serem e permanecerem anônimos, isto é, não terem 
seus nomes devidamente citados nas publicações, etiquetas das obras nas exposições, sites ou blogs, é o suficiente para esvaziar qualquer discurso que clama sua efetiva participação autoral nos trabalhos. É este deslize, o completo esquecimento do nome do coautor, sempre reiterado, que revela a intencionalidade instrumental diante do transeunte e, não a manutenção, mas o aprofundamento das relações hierárquicas clássicas na disciplina: a conversão do espectador em material da obra constitui, é possível aventar, um retrocesso pelo menos no que diz respeito à sua suposta participação efetiva na cadeia de produção. Se antes, o espectador se deslocava até os espaços culturais, com o intuito de observar a produção alheia, agora, com trabalhos que clamam participação no espaço público, é invadido em sua rotina. Afinal, a questão primordial, dentro do referencial democrático, de participação e de autonomia, não seria a concordância do indivíduo em figurar como coautor de qualquer empreendimento? O discurso - evocativo de democratização e antielitismo - entra assim em conflito direto, portanto, com a prática invasiva no espaço público aproximando os "guerrilheiros" do quadro instituído.

Outra modalidade de interação entre obra, artista e espectador, denominado muitas vezes de coautor pelo discurso hegemônico, é aquela que tem por objetivo tirar o transeunte da rotina perceptiva e do ostracismo cultural. A metodologia não é diferente daquela adotada na partilha autoral e é comum que a coautoria e iluminação cultural sejam utilizadas juntas como um pacote messiânico. Aqui, mais uma vez capturado no contrapé de sua rotina, o andarilho tem a oportunidade de surpreender-se, perturbar-se e incomodar-se, de "reeducar o olhar do cotidiano", de "quebrar sua percepção". É o que se pode observar nos discursos de dois participantes do Paralela-ao-mar e do multiplicidade: projeto de ações e intervenções urbanas (SANTOS; TEIXEIRA, 2006), respectivamente:

Bom, pessoas a minha proposta é a seguinte: pretendo fazer uma intervenção nos supermercados e minimercados da cidade. A ideia é pegar rolos de papel higiênico e reembalar em quantidades inexistentes no mercado e colocá-los nas prateleiras desses comércios. Como se estivesse à venda... talvez até estejam, não sei bem ainda... Naum sei bem ainda em quais lugares ao certo, e a proposta é registrar as reações das pessoas diante da mercadoria (CAYRES, 2004, grifo meu) ${ }^{137}$.

Quando eu participo de eventos como esses que são na rua, são ações, eu costumo usar materiais perecíveis e que de certa forma perturbem um pouco a ordem do dia.

Gostaria de colocar num poste, escolham um bem interessante, por favor, vários peixes pendurados.

Manjubinhas, sardinhas, e pode já ser tudo meio passado, meio podre mesmo, penduradas pela cauda e amarradas no poste. tenho uma foto que mando anexada para você ter uma idéia de como a coisa funciona, mas os peixinhos tem que ser comprados, entende?

[...] Um poste que incomode um pouco... (PAPE, 2004b, grifos meus) ${ }^{138}$.

\footnotetext{
137 CAYRES, Ludmila. $\quad$ Eu tbm!!! $2004 . \quad$ Disponível <https://br.groups.yahoo.com/neo/groups/paralelaaomar/conversations/messages/16>. Acesso em: 10 abr. 2017.
138 PAPE,
Cristina.
paralela.
2004.
Disponível
em:

<https://br.groups.yahoo.com/neo/groups/paralelaaomar/conversations/messages/27>. Acesso em: 13 mai. 2017.
} 
Mas, pra quê 'inquietar as pessoas?' Massena sustenta que essas ações-intervenções do Entretantos buscam reeducar o olhar do citadino, empedernido pelo excesso, retrabalhar os pensamentos. A cidade é isso: tudo ao mesmo tempo querendo atenção (ALVES, 2006, grifo meu) ${ }^{139}$.

Eventos como o multipliCIDADE, o EIA e o Salão de m.a.i.o são extremamente importantes para criar diálogos entre 0 espaço público e a arte, além de oxigenar as discussões acerca da arte contemporânea e suas possibilidades, propondo ao público novas situações (de cunho não-autoral) que quebre a sua anestesia perceptiva, típicas da mesmice cotidiana (GIA In: SANTOS; TEIXEIRA, 2006, p.36, grifo meu).

O desejo artístico em incomodar, observar, educar e reavivar o transeunte das ruas indivíduo ordinário, inconsciente da elevação proposta nos empreendimentos artísticos contemporâneos e consumidor de uma vida repleta de clichês impostos pela indústria cultural estampado nos discursos coletados acima, demonstra não apenas a busca dos artistas por participação, atuação, controle e protagonismo no seu contexto, mas também um amálgama entre aspiração e certeza em obtê-los. Esta autoestima inabalável leva às condutas típicas da mainstream artística na qual o espectador, longe de receber poderes de participação ativa, é, pelo contrário, destituído de poder, consciência, desejo, gosto ou voz, para que possa ser tutelado, não mais pelo discurso do crítico de arte, como outrora, mas pelo próprio artista no boom da revolução informativa do século XXI. Seja no papel de pesquisador, controlando as variáveis pelas quais o transeunte será submetido, seja atuando como super-herói, esclarecendo ao passante desavisado, o artista assume ora a função de voyeur, ora a função de Deus, enquanto o espectador foi convertido em objeto necessário e, sobretudo, em uma espécie de componente da obra.

É evidente que esses exemplos não se aplicam a todas as propostas. Em algumas ocasiões, a preocupação em relação à participação do transeunte não é mencionada ou não parece constituir uma questão relevante. É possível afirmar que tal questão esteve mais presente nas propostas dos participantes do multipliCIDADE dos que as do Paralela-ao-mar. Nas mostras virtuais, propostas por alguns artistas para o Paralela-ao-mar, por exemplo, os trabalhos são disponibilizados para serem somente visualizados nos endereços eletrônicos ${ }^{140}$, enquanto outras intervenções adotaram a cidade em sentido mais próximo das proposições realizadas nas décadas de 1960 e 1970 que, visavam utilizar espaços de ação distintos dos convencionais. No caso do projeto multipliCIDADE, nas edições de 2006 e 2007, algumas propostas repõem por inversão, por exemplo, o clamor por visibilidade, pressupondo um transeunte atento a detalhes ínfimos, capaz de detectar em meio ao caos urbano inscrições

139 ALVES, Henrique. Cegos de tanto ver. Século Diário. Nov. 2006. Disponível em: <http://www.seculodiario.com.br/arquivo/2006/novembro/21/cadernoatracoes/cultura/01.asp >. Acesso em: 20 mai. 2017.

140 São exemplos disso: a proposta de Reginaldo Leite que constituiu em apresentar quinze pinturas inéditas no seu site http://geocities.yahoo.com.br/rcleitebr/ e a de Marcelo Gandini que realizou uma mostra virtual com alguns de seus trabalhos no fotolog <http://fotolog.terra.com.br/marcelogandini>. 
discretas no espaço ou, ainda a apropriação da cidade não necessariamente pretendia alavancar uma interação mais efetiva com o passante. A intervenção Traços de ausência (2007) proposta pelas artistas capixabas do Grupo Éra, Amanda Freitas e Rubiane Maia, serve para ilustrar essa última questão. Neste trabalho, a intenção era tracejar com tinta branca duas linhas paralelas no asfalto da Avenida Fernando Ferrari, no local antes ocupado por uma passarela de pedestres utilizada para ter acesso à UFES: "É uma ação simples que remete à ausência e à sutileza do não-mais" (multipliCIDADE, 2007). Enquanto, as imagens de modestos ralos dispostas em locais discretos que fazem parte da intervenção Mapa de riscos ambientais (2006) (Fig. 06) proposta pela artista gaúcha Camila Mello, exemplifica a ideia de inserção comedida.

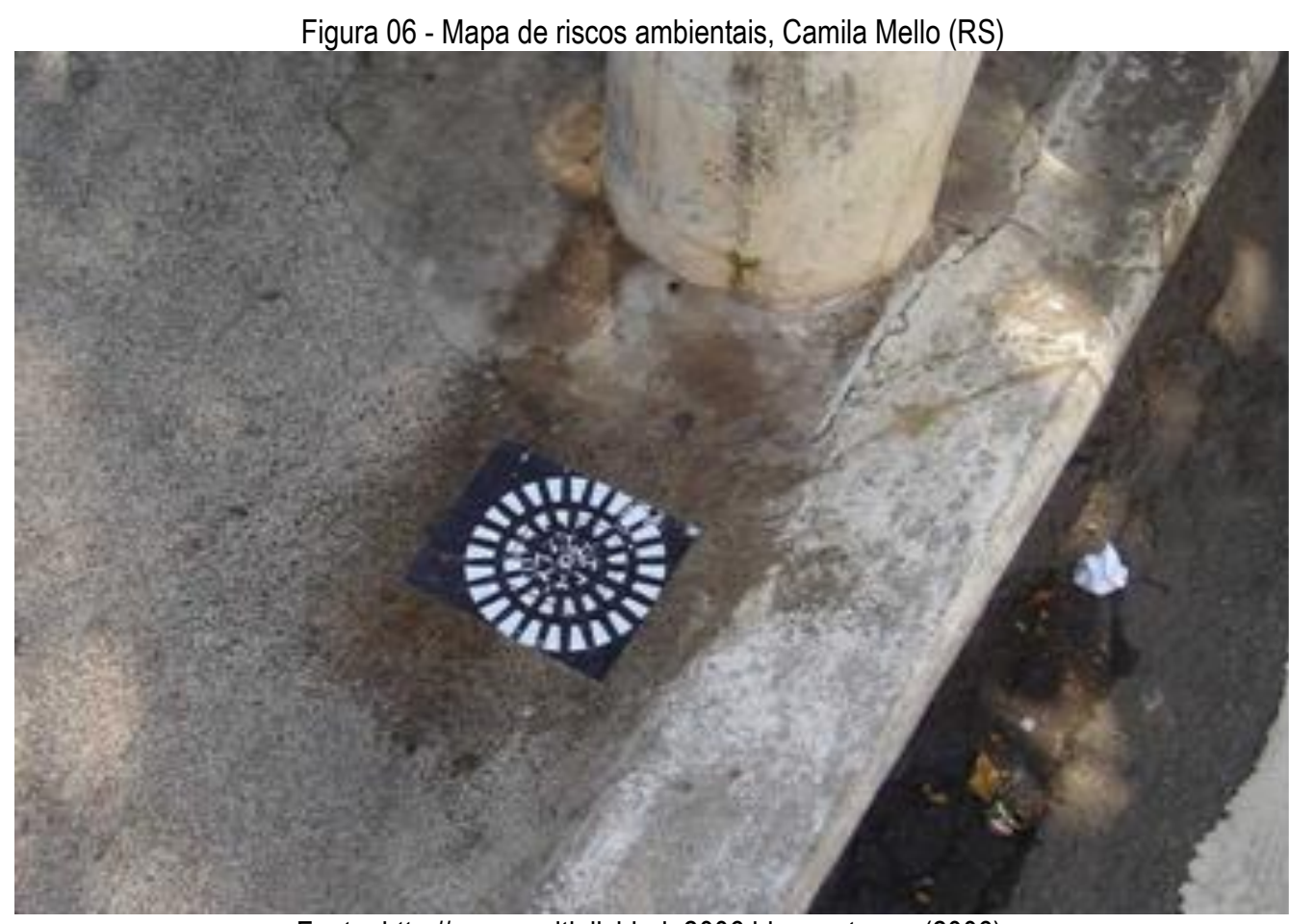

Fonte: http://www.multiplicidade2006.blogspot.com (2006).

Por outro ângulo, a performance Barato é aqui (2006) (Fig. 07) do paraense Pedro Olaia, propõe a noção de incomodar o transeunte de forma inversa a outros exemplos citados anteriormente. Nesta, dentro de uma gaiola colocada na Praça Costa Pereira, no Centro de Vitória, o artista listou uma série de agressões que o público poderia nele infligir mediante pagamento ${ }^{141}$. Cuspe, chute, tapa,

141 Pedro Olaia inverte a relação de pagamento proposta em diversos projetos que têm sido denominados de "estética remunerada", entre os quais, os desenvolvidos por Santiago Sierra, desde 1999. Se o artista espanhol remunera os participantes para executarem tarefas degradantes ou banais, Olaia (duplamente preso, por uma corrente envolvendo seu pescoço e dentro de uma jaula) inclui a condição do artista na discussão. A relação dessa proposta com outras que envolvem participação e remuneração nos projetos artísticos recentes mereceria uma análise mais apurada, impossível de ser realizada no âmbito das discussões deste capítulo da tese. Cabe ressaltar que é possível consultar um vídeo com as 
cutucada, dedada etc. estão entre os "serviços" ofertados com valores discriminados na placa presa à grade. No resumo de sua proposta, ele indagou: "o que sentimos e como agimos em relação a um próximo ou desconhecido? [...] o que omitimos de nós mesmos? qual o valor de cada sentimento?" (Entretantos, 2006). É possível supor que essa performance tenha motivado a inclusão no regulamento da edição seguinte do evento da cláusula - já mencionada - que obrigava que 0 acesso às ações fossem públicos e gratuitos. Tal questão conduz a aventar ainda, que o tipo de interação com 0 transeunte foi paulatina e tacitamente sendo padronizada: interferências ou utilização da sinalização urbana, distribuição de panfletos, faixas com indagações provocativas, inserções de elementos lúdicos (brinquedos, doces, objetos caseiros) predominam. Humor, irreverência, provocação, estranhamento, incômodo etc. são almejados, porém, "ruídos" mais contundentes, como foi o caso da performance apresentada por Pedro Olaia, acabam destoando desse conjunto composto por temas, materiais e incitações relativamente consensuais.

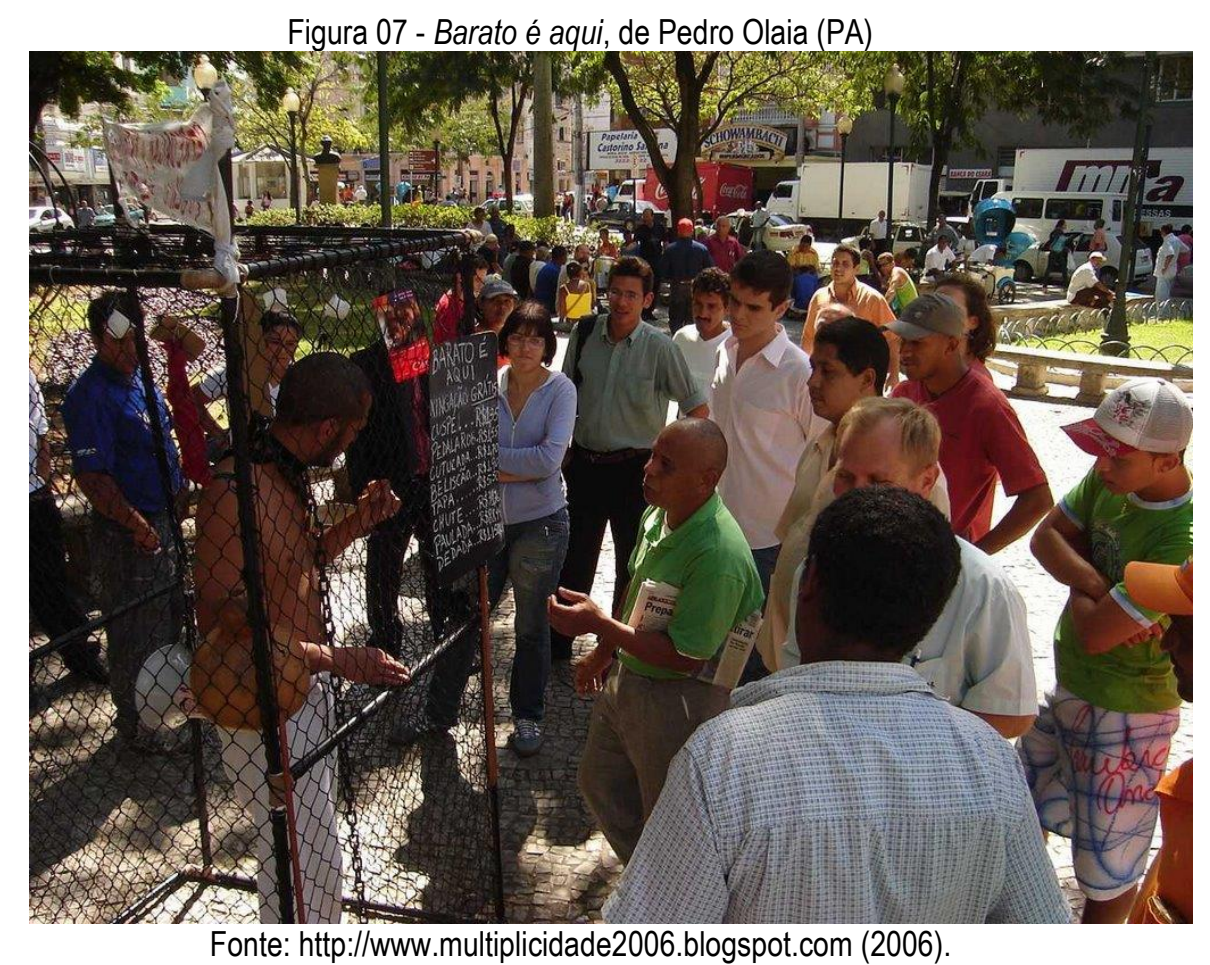

Por outro lado, a extradisciplinaridade exercida pelo Cine Falcatrua determinou também sua comunicação e interação de suas atividades com o público de maneira diferenciada daquela dos coletivos Maruípe e Entretantos. Com a ausência de uma disciplina específica à qual se referir, contrapondo-se de modo positivo ou negativo, o grupo pautou sua atuação de acordo com o seu

intervenções realizadas em Vitória. Disponível em: <https://www.youtube.com/watch?v=mjNZ4h8lkZk>. Acesso em: 10 jan. 2018. 
pragmatismo e ironia característicos. A participação do público nas atividades realizadas pelo grupo, embora aparentemente não tenha atingido a central administrativa da instituição, foi, em muitos aspectos, além da ideia de participação evocada até então pelos outros dois coletivos aqui analisados.

\footnotetext{
Quem estiver com vontade de ajudar na montagem da sessão de hoje é só aparecer no auditório do CEMUNI IV por volta das $17 \mathrm{~h} 30$.

$[\ldots]$

Estamos precisando de ajuda para o transporte do computador (de um carro, o local é bem pertinho da UFES) (FALCATRUA, 2004).

Valeu a galera que ajudou a armar toda a tranqueira. Contribua você também com a sua mais-valia (FALCATRUA, 2004).
}

Cabe sublinhar, ainda, que, dos inúmeros filmes baixados, muitos não dispunham de legendas em português, dessa forma, seus membros incitavam aos que possuíam conhecimentos em outras línguas a auxiliarem: "Se você saca de inglês, francês ou javanês pode ajudar o Falcatrua, sabia?" (FALCATRUA, 2004).

Adotando como pressuposto que o trabalho do coletivo Cine Falcatrua estava circunscrito às atividades relacionadas ao cineclubismo, então a relação pactuada entre público e obra não seria muito diferente da relação instrumentalizada estabelecidas pelos grupos Maruípe e Entretantos, à exceção de um componente primordial: o desejo de participar. Embora ainda como componente da obra, matériaprima do trabalho, o público decide estar não apenas presente nas exibições, mas também contribuir com sua "mais valia". É esse acordo tácito entre os membros do coletivo e o seu público que torna a relação entre participantes menos idealizada.

Os motivos para a adesão às atividades do grupo, como audiência ou como staff, podem ser direcionados ao árido contexto do circuito de entretenimento contemporâneo no Espírito Santo. Vitória, no período em que o Cine Falcatrua surgiu, possuía um número reduzido de salas de cinema - oito no total, sendo que apenas uma, localizada na UFES, não era de caráter comercial - e até "[...] mesmo os blockbusters da estação demoravam a chegar à cidade" (MENOTTI, 2006). O trabalho do grupo com jogos, por meio de emuladores e roms, e a realização de pequenos campeonatos atraiu a atenção de um público diferente daqueles que frequentam eventos artísticos. Neste sentido, para alcançar uma audiência mais ampla, não restrita à comunidade universitária, o grupo divulgava suas atividades por emails e redes sociais, como Fotolog e Orkut ${ }^{142}$ (MENOTTI, 2006) e artigos na imprensa, reforçavam essa difusão. Em 11 de julho de 2004, o coletivo publica uma listagem intitulada "Falcatrua vira notícia"

142 Infelizmente, não foi localizado o backup de sua comunidade no Orkut. 
com os links de algumas dessas reportagens, afirmando que "Várias são as manifestações da imprensa por conta do videoclube Falcatrua, seja nacional seja local" (FALCATRUA, 2004).

O Cine Falcatrua desenvolveu atividades de difusão e esclarecimento relacionados diretamente com a natureza libertária de suas exibições em que o livre acesso à informação constituía a direção derivada dos ideais que passaram a ser acessíveis no Brasil com a chegada e disseminação da Internet a partir do final da década de 1990. Para tanto, ao mesmo tempo em que eles divulgavam suas atividades e incentivavam a disseminação da prática por meio de manuais, não desconheciam a crescente pressão exercida pelas gravadoras de música e pela indústria cinematográfica.

Tais questões são assuntos que aparecem nas discussões alavancadas pelo grupo que contrapõem informações sobre as ações que procuram deter as apropriações com movimentos que tentam repensar essas práticas por outras perspectivas. Colocam em pauta, por exemplo, o termo copyleft ${ }^{143}$ e outras formas de licença de uso, discutindo ainda, o anseio pela livre circulação da produção cultural e as manobras que acompanhavam e procuravam imobilizar as transmutações em curso no período.

Dessa forma, o coletivo indaga em alguns de seus textos o descompasso processual entre a produção, distribuição e exibição da indústria cinematográfica com a abertura das tecnologias digitais: "O que fazer com um filme depois que ele é terminado? Como fazê-lo chegar aos espectadores? Qual é a influência do tecido social nos critérios das distribuidoras?". Esclarecem ainda que "o que está em jogo [nas questões por eles propostas] não são discussões conceituais sobre a produção ou 0 significado dos filmes, e sim questões práticas normalmente deixadas de lado" (FALCATRUA, 2006). Entre essas questões práticas, além das exibições organizadas, o grupo se dedicava também a produzir materiais "didáticos" e oficinas que possuíam como proposta "[...] quebrar as barreiras da exclusão social e mostrar [que as pessoas] podem interferir e mudar a sua própria realidade" (FALCATRUA, 2004) ${ }^{144}$.

Impossível não associar o espírito exercido pelo Cine Falcatrua com aqueles encontrados na vanguarda da disseminação dos ideais de autonomia no início do século XXI. O Projeto GNU, criado em 1983 por Richard Stallman, como reação ao software proprietário - considerado uma ameaça à liberdade do usuário por restringir sua livre manipulação tanto da máquina quanto do próprio software

\footnotetext{
143 O termo foi inicialmente empregado por programadores de informática, que disponibilizam um software, bem como seu código-fonte para que outros usuários possam tanto executar, como alterar ou distribuí-lo, respectivamente. Posteriormente, passou a ser largamente utilizado por outras áreas da produção, englobando licenças como GPL, GFDL e as diversas licenças da Creative Commons, dentre outras.

$144 \quad 0$ texto da postagem anunciava e convidava para a primeira exibição de um videoclube criado na comunidade do Morro de São Benedito, em Vitória (ES), que foi montado nos moldes e com o auxílio do Cine Falcatrua.
} 
— tem sido um dos grandes empreendimentos libertários desde sua implementação. 0 projeto tinha como meta libertar o usuário do controle exercido pelas empresas, devolvendo-lhes a autonomia no uso de seu próprio aparelho. Para tanto, era necessário primeiro o desenvolvimento do sistema operacional para a posterior instalação dos outros componentes. A combinação entre o sistema GNU e o kernel Linux, desenvolvido por Linus Torvalds, originou o sistema GNU/Linux no início de 1992 (GNU, 2016). ${ }^{145} \mathrm{~A}$ influência e importância deste empreendimento não estão restritas ao âmbito da programação, mas podem ser visualizadas dentro de um espectro muito mais amplo da vida contemporânea. Dentre as quatro liberdades citadas na filosofia do projeto GNU - liberdade 0, de execução do programa; liberdade 1, de estudar e modificar o programa com seu código fonte; liberdade 2, de redistribuir cópias exatas do original; e, liberdade 3, de distribuir versões modificadas (GNU, 2016) - a liberdade 1, segunda liberdade ${ }^{146}$ é um item comumente localizado em vários outros projetos das mais diferentes áreas. Esta liberdade orientou, por exemplo, a criação de uma licença dedicada aos manuais de instrução e documentação de software livre e funciona como um desdobramento dessa filosofia libertária:

O propósito desta Licença é fazer um manual, livro didático, ou outro documento funcional e
útil que seja "livre" no sentido de liberdade [quer dizer, não associado a "livre" no sentido de
ser "grátis"]: garantir a todos a efetiva liberdade de copiar e redistribuí-lo, com ou sem
modificações, tanto comercialmente como não comercialmente. Paralelamente, esta Licença
preserva ao autor e à editora um modo de crédito de seu trabalho, não sendo responsáveis
pelas modificações feitas por outros.

Esta Licença é um tipo de "copyleft", o que significa que obras derivadas do documento devem ser livres no mesmo sentido. Ela completa a GNU General Public License, que é uma licença copyleft desenhada para software livre (GNU, 2016).

Outro empreendimento influente e que tem relação mais direta com as questões do Cine Falcatrua é o Project Guttenberg, concebido em 1971. Tal projeto partia do pressuposto de que qualquer arquivo que pudesse ser digitalizado poderia ser reproduzido indefinidamente, o único impedimento estaria no tempo de carência para que as obras entrassem em domínio público:

\begin{abstract}
A premissa em que Michael Hart baseou o Project Guttenberg foi: qualquer coisa que pode ser introduzida no computador pode ser indefinidamente reproduzida [...] o que Michael nomeou de "Tecnologia de Replicação". O conceito de tecnologia de replicação é simples; uma vez que um livro ou qualquer item (incluindo imagens, sons, e mesmo itens em 3-D podem ser armazenados em um computador), então qualquer número de cópias pode e estará disponível. Qualquer um no mundo, ou mesmo não apenas neste mundo (por conta da transmissão de satélites) pode ter uma cópia de um livro que foi armazenado em um computador (GUTTENBERG, 1992) ${ }^{147}$.
\end{abstract}

\footnotetext{
145 GNU History. 2016. Disponível em: <https://www.gnu.org/gnu/gnu-history.html>. Acesso em: 29 abr. 2017.

146 A explicação para esta contagem é a de que os programadores começam suas contagens com zero.

147 GUTTENBERG, Project. Gutenberg: The History and Philosophy of Project Gutenberg by Michael Hart. 1992. 
A noção de participação coletiva aventada pelo Cine Falcatrua, em seu momento inicial, possuía um amplo espectro: "Falcatrua é um coletivo e você pode vir a fazer parte dele [...]. Não paga nada, não cobra nada, não ganha nada (financeiramente falando)" (FALCATRUA, 2004). "Falcatrua em qualquer lugar" é o título de uma chamada que não somente volta a enfatizar o caráter colaborativo do projeto, mas também destaca a aspiração de dispersá-lo nos ambientes mais distintos, bem como, desloca a noção de conteúdo para os seus sentidos interpretativos, para as conexões que podem ser remanejadas a partir do repertório apresentado. O coletivo, neste caso, toma partido da filosofia em voga pelos empreendimentos mencionados e não funciona como mero aparato retórico e metodológico. Portanto, assim como o GNU Project, os empreendimentos da Wikimedia, Project Guttenberg, o Cine Falcatrua depende da participação e colaboração coletiva ao mesmo tempo em que fornece o retorno requerido pela própria comunidade. Nesta filosofia, há colaboração em que todos trabalham em torno de um ideal comum e desejado pelos participantes:

O Cine Falcatrua é uma construção coletiva. Você pode levar o projeto para onde imaginar, escola, teatros, outras faculdades, presídios, outros lugares da UFES, CEFET. Você que tem interesse nos procure para saber o que é necessário para realizar uma de nossas sessões. Não tem mistério. 0 filme é uma fatalidade de quem vê (FALCATRUA, 2004, grifo meu).

O Cine Falcatrua parecia imbuído desse espírito hacker, ansioso em expor os processos e procurando desmistificar como as coisas são formadas, ou, como afirmou Brian Holmes, evocando as análises de Bruno Latour sobre as questões da tecnopolítica, possuíam a ambição de "[...] 'tornar as coisas públicas' ou, mais precisamente, elucidar os encontros específicos entre objetos tecnicamente complexos e processos específicos de tomadas de decisão" (HOLMES, 2008, p.12). Holmes destacou que Latour "[...] apregoa que, para tanto, é preciso proceder sob a forma de 'provas' - estabelecidas 0 mais rigorosamente possível e ao mesmo tempo 'bagunçadas' - como as coisas do mundo em si" (HOLMES, 2008, p.12) ${ }^{148}$. Nesse sentido, nas sessões promovidas pelo grupo, o dispositivo de projeção era frequentemente montado na frente da plateia - algumas vezes, o público até participava da instalação - que testemunhava "[...] toda a transformação do espaço ordinário em sala de cinema". Além disso, "cartilhas de 'como fazer seu próprio cineminha' eram distribuídas entre os espectadores".

$<$ https://www.gutenberg.org/wiki/Gutenberg:The_History_and_Philosophy_of_Project_Gutenberg_by_Michael_Hart>. Acesso em: 29 abr. 2017.

$148 \quad$ Ressalta-se que, o texto de Bruno Latour que Brian Holmes faz referência é From Realpolitik to Dingpolitik - or How to Make Things Public, que serve de introdução ao livro Making things public: atmospheres of democracy (2005). Tratase de um trabalho editorial (um desdobramento da exposição lconoclash — ZKM/2002) de grande envergadura, que mesclou reflexões atuais com textos clássicos (William Shakespeare, La Fontaine e Jonathan Swift são alguns exemplos da literatura), em quinze tópicos que examinam o problema da representação política, em uma época que paira em muitas pessoas dúvidas acerca das repostas políticas padronizadas frente aos problemas contemporâneos (LATOUR, 2005). LATOUR, B. and WEIBEL, P. (Eds.). Making things public: atmospheres of democracy. Cambridge, Mass: MIT Press, 2005. 
Existia, portanto, "uma vontade de expor o truque e ainda assim insistir na ilusão da plateia", estabelecendo "um jogo entre sedução e franqueza" (MENOTTI, 2006, p.5).

[...]. Seus inventores, que amadureceram no universo do capitalismo cognitivo, são levados a funções sociais complexas, as quais eles apreendem todos os detalhes técnicos e com a consciência total de que a segunda natureza do mundo agora é estruturada pela tecnologia e sua forma organizacional. É o compromisso político [...] que thes dá o desejo de perseguir suas investigações exigentes para além dos limites de uma disciplina artística ou acadêmica. Porém, seus processos analíticos são ao mesmo tempo expressivos, e, para eles, toda máquina complexa é impregnada de afeto e de subjetividade (HOLMES, 2008, p.12, grifo meu).

O público tinha influência também, de maneira direta ou indireta, sobre a curadoria do material projetado. A exibição era constituída por uma mescla heterogênea de gêneros "[...] desde blockbusters da estação até títulos esquecidos de videoarte e documentários independentes de países estrangeiros" (MENOTTI, 2015, p. 99), sendo que a seleção do que seria exibido não ficava restrita aos integrantes do coletivo ${ }^{149}$.

Seguindo uma lógica há muito presente nas indagações tanto no âmbito das artes visuais quanto da literatura, os membros do Cine Falcatrua enfatizam: "O filme é uma fatalidade de quem vê" (FALCATRUA, 2004). Nesse sentido, Robert Smithson, em 1971, por exemplo, indagou: "Faz diferença a que filme assistimos? Talvez. Se há uma coisa que todos os filmes têm em comum é o poder de transportar nossa percepção para outro lugar" (SMITHSON, 2007, p.66)150, enquanto Jorge Luís Borges, conforme mencionou Roger Chartier, conferiu às transformações na acepção dos livros às mutações dos modos de ler: "O livro não é uma entidade enclausurada: é uma relação, é o centro de inúmeras relações. Seja ela anterior ou posterior, uma literatura difere de outra, menos pelo texto do que pelo modo como ela é lida" (CHARTIER, 2010, p.23). Entretanto, no contexto da tradição cineclubista, especialmente dentro do ambiente universitário, a não hierarquização do conteúdo e a não pretensão de alavancar debates teóricos, retira a familiaridade das conviç̧ões tacitamente compactuadas. Segundo declarou Fabrício Noronha, integrante do coletivo, "[...] a UFES não pode 'descobrir' que as noites de terça-feira não são uma ode à cultura nacional, com discussões filosóficas, antropológicas e estéticas sobre Cinema Novo e Chanchada", acrescentado que, o projeto menciona apenas 0 intuito de divulgar filmes, entretanto, "eles (UFES) não sabem exatamente que tipo de

149 Tal prática pode ser detectada na produção de diversos artistas do período. Rirkrit Tiravanija, por exemplo, em uma das edições do projeto Cinema Liberté - realizada em Glasgow (Escócia - Reino Unido), em 1999 - solicitou "ao público local indicações de quais eram seus filmes preferidos, que foram projetados, em uma tela ao ar livre no cruzamento de duas ruas em Glasgow". Deve-se ressaltar, entretanto, que este exemplo serviu apenas para ilustrar o desejo contemporâneo de reposicionar a relação entre artista e público, já que as demais questões tanto contextuais quanto propositivas entre o Cine Falcatrua e Tiravanija, mereceriam uma análise mais detalhada (BISHOP, 2004, p.57).

${ }_{150} \quad 0$ texto foi originalmente publicado em 1971, na edição de setembro da Artforum, dedicada ao cinema. SMITHSON, Robert. Atopia cinemática. Caderno Sesc Videobrasil/SESC-SP, Associação Cultual Videobrasil, v. 3, n.3, p.66-73, 2007. 
videoclube montamos" 151 . A curadoria do material exibido, portanto, era ditada mais por uma necessidade coletiva do que pela imposição de uma disciplina que dita os gostos pelo discurso ${ }^{152}$. Conforme sugeriu Andreas Huyssen (2000), a dicotomia entre cultura erudita e de massa, no período mais recente, não pode mais ser pensada como sendo mutuamente excludentes, já que questões cruciais da cultura contemporânea estão situadas no seu limiar (HUYSSEN, 2000, p.22)153.

Segundo Gabriel Menotti (2015, p.106), as controvérsias geradas pelas ações iniciais do Cine Falcatrua, contribuíram para a rearticulação política do movimento cineclubista no Brasil, levando o Ministério da Cultura "[...] a criar em 2007 um edital para 'Pontos de Difusão Digital', que tinha por objetivo distribuir equipamentos de projeção, junto com um pacote de filmes brasileiros em DVD" (2015, p.106). Para o autor, o suporte para a criação dessa estrutura trouxe também uma série de restrições para a prática: ser pessoa jurídica, comunicar por meio de relatórios, as atividades realizadas, organizando determinado número de exibições mensais com os filmes disponibilizados. Além disso, esses cineclubes poderiam ter seu "equipamento apreendido caso exibissem obras piratas. Nesse sentido, a localização das práticas de cineclubismo digital parece tê-las cristalizado, limitando seu campo de operação" (2015, p.107). Por outro viés, o autor detectou também limitações ao projeto no campo artístico, que foi "[...] completamente reenquadrado: da curadoria de cinema, passou a implicar a produção de obras", reduzindo sua atividade "a uma encenação de si mesma, desarmada de suas implicações iniciais" (2015, p.107).

\subsection{CONFRONTOS, DEMARCAÇÕES E ASSOCIAÇÕES}

151 A citação consta em um recorte de uma reportagem jornalística que, considerando as informações sobre as atividades do projeto, foi escrita em meados de 2004. Intitulada Cine Falcatrua: uma subversão muito bem-vinda, a matéria com duas laudas foi assinada por Roberta Monteiro, sendo que a citação mencionada, consta na página 63 . Ressalta-se que a imagem da reportagem já não pode mais ser visualizada nas publicações do grupo na internet.

152 Exemplificando o que foi exposto, os integrantes do Cine Falcatrua durante entrevista à Rádio Universitária, em 2013, afirmaram que uma das sessões com maior número de pessoas foi a que exibiu o filme Amor Estranho Amor (1982) de Walter Hugo Khouri. Neste, a apresentadora Xuxa Meneghel aparece nua e seduzindo um pré-adolescente. Em 1987, a apresentadora entrou com um processo na justiça, conseguindo que as cópias em VHS fossem retiradas das locadoras. "Desse modo, Amor Estranho Amor adquiriu um status lendário: embora muitos já tivessem ouvido falar sobre ele, poucos haviam visto sequer uma cena do filme" (MENOTTI, 2015, p.103).

153 É necessário contextualizar a colocação do autor. A partir da pergunta "Por que estamos construindo museus como se não houvesse amanhã?" (2000, p.20) Andreas Huyssen considera que, por mais que desejamos não existem mais espaços puros e situados fora da cultura da mercadoria. Assim, ele argumenta que o problema não é resolvido opondo memória séria à memória trivial, pois isso apenas reproduziria a velha dicotomia entre alta e baixa cultura. Cf. HUYSSEN, Andreas. Seduzidos pela memória: arquitetura, monumento, mídia. Tradução Sérgio Alcides. 2. ed. Rio de Janeiro: Aeroplano, 2004. 
No quesito enfrentamento, nenhum dos coletivos em questão parece ter se arriscado tanto quanto o Cine Falcatrua. Há, de fato, uma diferença abissal entre as contestações metafóricas, poéticas ou simbólicas organizadas pelos coletivos Maruípe e Entretantos - eliminação da seleção para participação de evento e o tipo mais recorrente de apropriação do espaço público, respectivamente, constituem alguns exemplos - em que as normas da disciplina são desafiadas com sutileza envernizante na já incorporada ética vanguardista, e os desvios não apenas estéticos, mas também legais realizados pelo Cine Falcatrua.

Enfatizar essa distinção não é hierarquizar as práticas artísticas em um pódio dos mais ousados, na qual o terreno metafórico atingiria uma pontuação menor em relação à adrenalina provocada pelas transgressões passíveis de penas mais duras do que simplesmente ficar fora dos próximos salões locais por ter criticado o processo de seleção, mas sim, de tocar em um ponto sensível da problemática relação entre arte e política. O exame proposto, portanto, da disparidade entre o plano abstrato e o plano concreto dos atos proibidos, longe de estar direcionado aos ditames quantitativos, no sentido de identificar qual apresenta maior potencial contestatório ou de disseminação de ideais de insatisfação, adere ao paradigma qualitativo centrado na seguinte questão: qual a especificidade apreendida da diferença entre o comportamento anárquico restrito ao simbólico e aquele que é extravasado ao campo do concreto? A análise da trajetória de enfrentamentos do Cine Falcatrua pode oferecer alguma resposta.

A ousadia, o deboche e o desrespeito à mainstream, comportamentos típicos dos grupos de enfrentamento como hackers e pichadores podem ser encontrados na atuação do Cine Falcatrua. Como exemplo, o marketing do documentário, denominado TV Falcatrua, com duração de três minutos, é descrito em sua sinopse como um "Breve registro das atividades do Cine Falcatrua, que utiliza tecnologias digitais caseiras para emular uma sala de cinema de verdade"154 e divulgado no seu fotolog da seguinte forma: "Baixe aqui o programinha piloto da TV Falcatrua, documentação necessária para denunciar esses moleques para a polícia federal" (FALCATRUA, 2004). Esta espécie de premonição ao processo que mais tarde foi movido pelas distribuidoras Lumière e Europa Filmes contra a UFES revela a consciência dos possíveis desdobramentos de responsabilização legal a que o grupo estava sujeito. Vale destacar que, na medida em que ocorria uma ampliação do número de filmes baixados na internet, houve uma intensificação das ações que procuravam deter essa expansão, o que torna a organização e institucionalização desta prática em torno de um coletivo, um enfrentamento declarado.

$154 \quad$ Este documentário foi disponibilizado pelo grupo em 14 de julho de 2004 e não está mais disponível, restando apenas informações técnicas sobre o mesmo (CURTAS, 2015). 
Tal questão pode ser em parte vislumbrada na adaptação de um texto da Agence France-Presse (AFP) publicada no fotolog do coletivo, em 16 de junho de 2004, no qual, seus integrantes informam:

No mesmo dia em que o Cine Falcatrua exibia mais um de seus filmes baixados na internet, a Associação do Cinema Americano (Motion Picture Association of America - MPAA ${ }^{155}$ ) anunciou que pretende combater duramente a pirataria de filmes na internet. A ideia inicial é lançar uma campanha falando sobre as consequências que isso pode ter na justiça (FALCATRUA, 2004).

A reportagem Universidade federal em Vitória decreta "falcatrua", publicada em 29 de julho de 2004 (ASSIS, 2004) no jornal Folha de S. Paulo, acabou desencadeando uma espécie de ponto de inflexão na trajetória do projeto. $O$ texto jornalístico poderia ter sido mais um, dentre tantos outros desses cadernos culturais que, ao concederem espaço para iniciativas desenvolvidas em lugares "remotos" do país, fornecem ao leitor dos centros hegemônicos um contraponto, um panorama mais diversificado das atividades culturais brasileiras. O lugar reservado à matéria na página do impresso fornece alguns indícios que são também reforçados no texto. Ela foi acomodada de forma discreta no canto inferior direito da última página do caderno llustrada, dividindo o espaço com uma propaganda bastante chamativa do próprio jornal — com fundo azul e letras amarelas — enquanto toda a metade superior estava ocupada com uma entrevista com o músico João Donato156.

O destaque da página era para o músico já consagrado que ressaltava a importância da liberdade de criação - "[...]. Não pode tentar enclausurar a música como se fosse um pássaro na gaiola" (SANCHES, 2004), afirmou João Donato em um dos trechos da entrevista —, em contraposição o texto sobre a iniciativa dos estudantes universitários de Vitória é traçado em linhas diametralmente opostas. Pensada no seu conjunto, a página do jornal (Fig. 08) abarca diversas contradições que permeiam o período, entre as quais, a exaltação dos ideais de liberdade e a destituição desses mesmos ideais, no caso aqui em questão, em nome de uma legislação que já não mais comportava as mudanças em curso na sociedade. Analisado isoladamente, o texto sobre a iniciativa do grupo capixaba reforça tais contradições. Contradições, que esses grupos independentes, como foi o caso do Cine Falcatrua, com suas iniciativas de levar a cabo ações políticas estavam mundialmente fomentando.

Figura 08 - Página do jornal Folha de S. Paulo

\footnotetext{
155 Trata-se de uma organização, criada em 1922, que possui como objetivo defender os interesses dos grandes produtores de filme norte-americanos. Suas ações incluem desde a classificação de filmes por faixa etária até assuntos que englobam direitos autorais e pirataria. Segundo consta no site da organização, sua missão principal é fazer "avançar o negócio e a arte do cinema [...] e garantir a satisfação do seu público-alvo em todo o mundo". Disponível em: $<$ http://www.mpaa.org/our-story/>. Acesso em: 21 set. 2016.

156 Interessante notar que João Donato, apesar de ter consolidado sua carreira no Rio de Janeiro, no período de efervescência da Bossa Nova, nasceu em Rio Branco, capital do Acre (SANCHES, 2004).
} 


\section{João Donato completa 70 anos de liberdade}

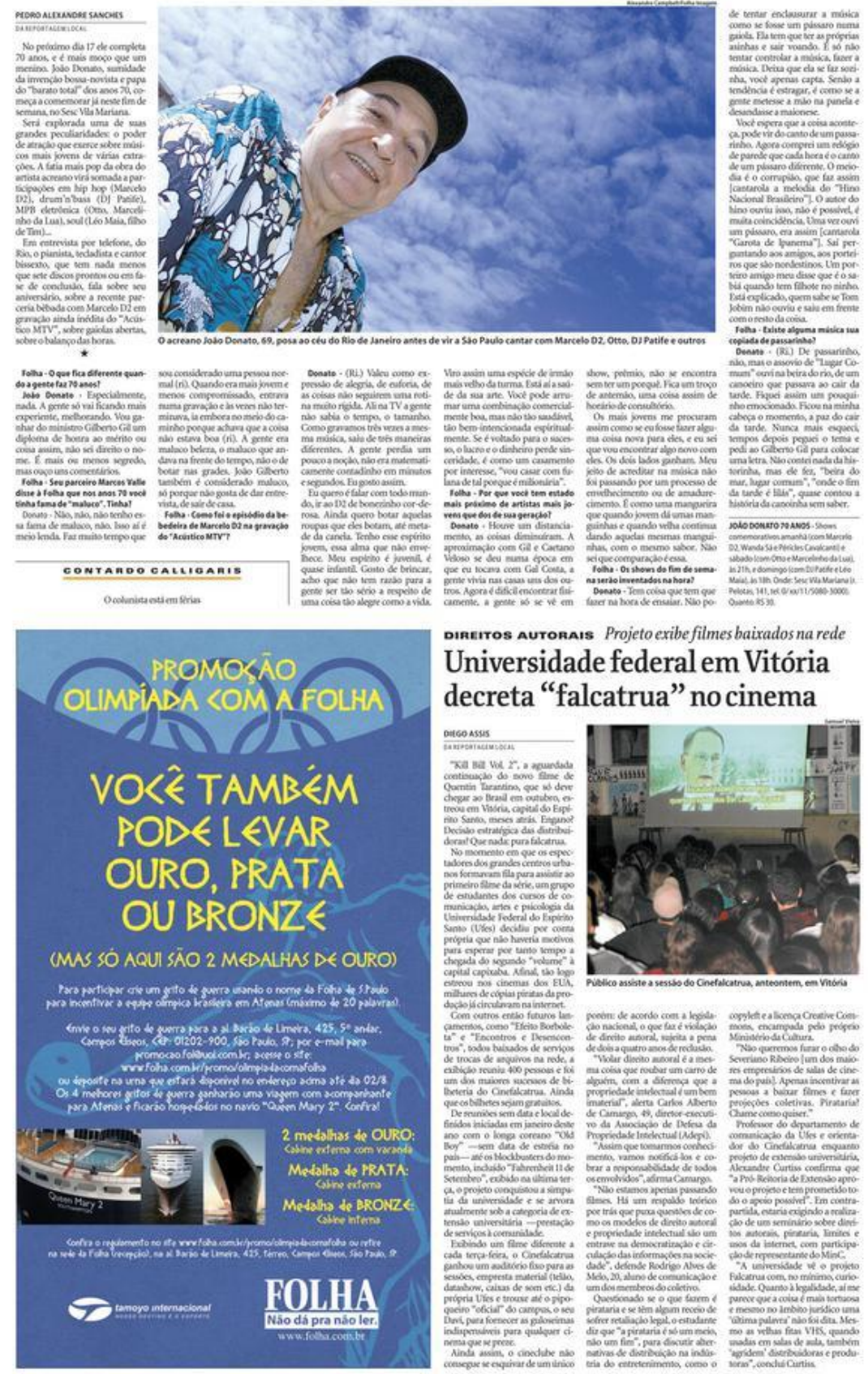

Fonte: Folha de S. Paulo de 29 de julho de 2004 (2004).

O que a matéria colocou em pauta foi principalmente a questão dos direitos autorais, adotando - em alguns momentos de forma explícita - posicionamento favorável ao discurso corrente apregoado nas campanhas moralizantes de combate à pirataria conduzidas no Brasil especialmente por entidades de defesa de interesses unilaterais ${ }^{157}$ como a ADEPI (Associação de Defesa da

157 Carlos Gerbase destacou que no Brasil os distribuidores são os grandes responsáveis pelas campanhas de combate à pirataria, uma vez que, o capital, não está concentrado nem nas empresas produtoras, nem nas mãos dos 
Propriedade Intelectual) e a APDIF (Associação Protetora dos Direitos Intelectuais Fonográficos) ${ }^{158}$. 0 jornalista entrevistou os participantes do Cine Falcatrua, mas antes de expor a opinião do diretorexecutivo da ADEPI, sublinhou: "[...] o cineclube não consegue se esquivar de um único porém: de acordo com a legislação nacional, o que faz é violação de direito autoral, sujeita a pena de dois a quatro anos de reclusão" (ASSIS, 2004) ${ }^{159}$. Os trechos mencionados na reportagem da entrevista pelo diretor-executivo da ADEPI, Carlos Alberto de Camargo, servem para reforçar a sentença anterior: "Violar direito autoral é a mesma coisa que roubar um carro de alguém, com a diferença que a propriedade intelectual é um bem imaterial" e, acrescenta "Assim que tomarmos conhecimento, vamos notificá-los e cobrar a responsabilidade de todos os envolvidos" (ASSIS, 2004).

A recepção da reportagem pelos membros do coletivo é exposta no dia seguinte a sua publicação. Classificada como chata e perdida entre "maniqueísmos jornalísticos", os integrantes do grupo acusam-na de ignorar aspectos interessantes do projeto, revelando-se como mais uma matéria sobre pirataria, fazendo alarde sobre a conivência da universidade "[...] com uma coisa que ainda é considerada ilegal". "[...]. Quem quer saber disso? Alguma novidade? Todo mundo faz isso, em todo lugar" (FALCATRUA, 2004), questionaram. Resumindo alguns dos desencadeamentos gerados pela reportagem, Menotti afirmou:

Conforme essa notícia se espalhou pelo país, ela veio atrair a atenção de duas distribuidoras
(Lumière e Europa Filmes) cujas obras haviam sido exibidas pelo cineclube (Kill Bill I e II e
Fahrenheit 11 de Setembro). Menos de duas semanas depois, a universidade seria
processada por essas empresas, além de receber uma queixa-crime movida pela ADEPI
contra os participantes do projeto. O processo acusava a universidade de "concorrência
desleal" (MENOTTI, 2015, p.105).

Em 12 de agosto de 2004, outra reportagem, assinada pelo mesmo jornalista da Folha de $S$. Paulo, informava sobre a repercussão causada pela publicação anterior: "A ação movida [...] em nome das distribuidoras [...] ostenta como prova a reportagem publicada pela Folha" (ASSIS, 2004, grifo do autor). Essa segunda matéria, além de anunciar que uma liminar exigiu o encerramento das atividades

realizadores. "A Motion Pictures Association (MPA), que nos Estados Unidos é uma associação de produtores, aqui no Brasil se relaciona basicamente com os distribuidores, nesta e em outras ações voltadas ao mercado" (GERBASE, 2008, p.140).

${ }_{158} \quad$ A APCM (Associação Antipirataria de Cinema e Música), criada em 2007, é resultado da fusão das duas associações mencionadas (APCM, 2014).

159 Cabe ressaltar, que a posição ingênua, por não ser reflexiva, e ignorante, por não ter conhecimento sobre o tema, adotada pelo jornalista em relação ao Cine Falcatrua, é semelhante a outras abordagens dele, tanto anteriores quanto posteriores. Ao escrever, em 2003, sobre a reedição no Brasil do livro Neuromancer, do autor norte-americano William Gibson, que inspirou a trilogia Matrix, o jornalista sublinha uma frase que atribui ao autor do romance policial, na qual ele classifica os hackers como pessoas entediadas tentando quebrar o sistema (ASSIS, 2003). Em outra matéria, escrita em 2005, após expor as ações antipublicidade do coletivo paulistano Os Bigodistas, que pintaram bigodes em diversos outdoors da cidade, o jornalista na sua má sucedida tentativa de resposta por parte dos responsáveis pelos departamentos de marketing e assessoria de impressa das empresas que foram alvo das ações do grupo, conclui o texto, evocando 0 Código Penal brasileiro. Segundo ele, as intervenções poderiam ser classificadas como dano e a pena prevista é de um a seis meses de detenção e multa (ASSIS, 2005). 
do projeto e a apreensão do material usado para as sessões, informava também que "[...] a Associação Brasileira de Multiplex (ABRAPLEX) e a ADEPI enviaram carta à reitoria da UFES pedindo a suspensão do projeto" (ASSIS, 2004b). Se a frase que iniciou o texto foi "Acabou a falcatrua", em seu encerramento, o autor informou: "Na noite de terça, o Falcatrua exibiu o curta de animação em massinha 'More', tendo como fonte um DVD encartado numa revista comprada na Califórnia" (ASSIS, 2004b). Na declaração de Gabriel Menotti, é possível observar uma síntese da separação entre o plano poético e os ditames do Código Penal Brasileiro, em que a natureza das consequências do enfrentamento são certamente distintas:

[...]. A partir desse ponto, o maior desafio do cineclube não era propor diferentes perspectivas sobre as especificidades do cinema - declarando, por exemplo, que a existência de um filme era secundária a sua exibição -, mas sim sustentar essas perspectivas em um tribunal (MENOTTI, 2015, p.105, grifo do autor).

Desprotegidos dos condões metafóricos as penas às infrações não possui elixir restaurador. Não é por acaso que a institucionalização ou filiação a instituições artísticas tem sido a saída para grupos que pretendem operar na materialidade dos fatos. Refúgio traiçoeiro, entretanto, a guarida nas casas que defendem a tradição artística, seja ela anacrônica ou de vanguarda, tem seu custo. Partindo da experiência do Cine Falcatrua, é possível distinguir problemas envolvendo a institucionalização e a renovação dos paradigmas diante de novas ferramentas, o direito real às informações, a suavização de enfrentamentos, a identificação e responsabilização dos indivíduos.

A primeira relação problemática derivada da institucionalização decorre das mutações desencadeadas pela tecnologia que colocaram em xeque divisões tradicionais. Roger Chartier ao analisá-las no âmbito da textualidade digital, afirmou que ao "[...] quebrar o vínculo antigo estabelecido entre textos e objetos, entre discurso e materialidade, a revolução digital obriga a uma revisão radical dos gestos e noções que associamos ao escrito" (CHARTIER, 2010, p.9). Para o autor, o vocabulário inerte tenta acomodar as inovações utilizando palavras familiares, porém, "os fragmentos de textos que aparecem no monitor não são páginas, mas composições singulares e efêmeras" (CHARTIER, 2010, p. 8-9). Assim, ele propõe uma série de indagações:

Como manter o conceito de propriedade literária, definido desde o século XVIII a partir de uma identidade perpetuada das obras, reconhecível, qualquer que seja a forma de sua publicação, num mundo em que os textos são móveis, maleáveis, abertos e nos quais, como o desejava Michel Foucault, cada um pode, no momento de começar, "encadear, continuar a frase, e, sem que ninguém se preocupe realmente com isso, alojar-se nos seus interstícios"? Como reconhecer uma ordem dos discursos [...] associando estreitamente autoridade de saber e forma de publicação, quando as possibilidades técnicas permitem, sem controles nem prazos, a circulação universal das opiniões e dos conhecimentos, como também dos erros e das falsificações? Como preservar modos de ler que constroem a significação partindo da coexistência de textos num mesmo objeto [...], enquanto o novo modo de conservação e transmissão dos escritos impõe à leitura uma lógica analítica e enciclopédica na qual os textos têm como único contexto aquele que lhes vem de seu pertencimento a uma mesma rubrica? (CHARTIER, 2010, p.9-11). 
As questões lançadas por Roger Chartier são pertinentes para pensar as apropriações realizadas pelos membros do Cine Falcatrua, conforme descritas por Gabriel Menotti ao sublinhar o caráter ambíguo tanto de parte considerável dos filmes mostrados quanto das adaptações requeridas ao espaço de exibição. Em relação ao material exibido, Menotti ressaltou que parte considerável era constituída por filmes encontrados na internet - "quem poderia assegurar sua legitimidade?" (MENOTTI, 2015, p.100) perguntou o autor - colocados na rede, em algumas ocasiões, em versões distintas daquelas que circulavam oficialmente, oscilando entre cópias gravadas durante as exibições e aquelas distribuídas em caráter promocional antes do lançamento comercial ${ }^{160}$.

Ainda que em escala imensuravelmente mais ampla e diversa, é possível traçar alguns paralelos do caso do Cine Falcatrua ao da plataforma Wikileaks ${ }^{161}$, Aaron Swartz e Pirate Bay. No primeiro exemplo, as punições das ações de desobediência civil digital da organização - feitas em caráter coletivo e de forma anônima - tiveram como foco a figura individual de seu fundador e editor, Julian Assange, que curiosamente acabou refugiado na embaixada do Equador em Londres, por questões de ordem pessoal com a justiça sueca e não pelas ações ativistas em relação, por exemplo, aos documentos confidenciais do governo norte-americano publicadas pela plataforma ${ }^{162}$. Aaron Swartz (1986-2013), por seu turno, atuou no combate à restrição de informação e foi processado por baixar sem permissão de acesso grandes volumes de publicações da revista científica JSTOR na rede do Massachusetts Institute of Technology (MIT). Questionando os pressupostos em relação à propriedade intelectual, Swartz era contrário à política da revista de remuneração das editoras, não pagamento dos autores e cobranças pelo acesso às publicações, muitas vezes financiadas com dinheiro público. Em 2013, após anos de processo por invasão de computadores, ameaçado de ficar preso por trinta e cinco anos, Swartz cometeu suicídio por enforcamento. Com a sua morte, as acusações contra ele foram retiradas pela promotoria e a editora inglesa Verso, para homenageá-lo, em 2016, disponibilizou, por um dia, o download gratuito do livro The Boy Who Could Change the World

\footnotetext{
160 Os dois tipos mais comuns apresentados nas sessões do Cine Falcatrua, segundo Menotti, são os cams e screeners. Se os cams - gravações feitas dentro do cinema por alguém posicionado na plateia — "[...] costumam apresentar uma imagem orgânica, característica do filme reprocessado em vídeo digital sem muito cuidado, com cores, enquadramento e velocidade alterados", os screeners apesar da qualidade técnica superior, muitas vezes, não trazem 0 conteúdo definitivo da versão final do filme, ou então "possuem indícios de sua condição extracomercial, como marcas d'água, cartelas de advertência ou trechos de imagem monocromática” (MENOTTI, 2015, p.100).

$161 \quad$ A plataforma Wikileaks é voltada para a divulgação de informações confidenciais de governos e empresas, sem fins lucrativos ou comerciais. Fundada por Julian Assange, teve início no final de 2006, ganhando repercussão mais ampla ao associar a divulgação dos conteúdos recebidos por atores diversificados com veículos tradicionais da mídia, entre os quais, The Guardian, Le Monde, The New York Times, etc..

$162 \quad$ Em artigo dedicado a analisar as ações do Wikileaks como exemplo de desobediência civil digital, Theresa Züger (ZÜGER, 2013) afirmou que não ocorreu nenhuma acusação pública contra a prática do fundador e dos seus colaboradores, sublinhando que as acusações foram apenas extraoficiais. ZÜGER, Theresa. Re-thinking civil disobedience. Internet Policy Review, v.2, n.4, nov. 2013.
} 
(uma coletânea com seus escritos) 163 . Outro caso emblemático de oposição à legislação de travamento da informação é o do site Pirate Bay, indexador de arquivos que eram de propriedade e compartilhados por usuários diversos. Embora declare expressamente que "Nenhum arquivo de torrent é guardado nos servidores" e que "isso significa que nenhum material com direitos autorais ou ilegal é mantido por nós"164, a organização foi alvo de diversos processos por violação ou apoio a violação de direitos autorais e de propriedade intelectual. Hoje, os servidores do Pirate Bay vivem uma espécie de jogo com as autoridades, deslocando-se entre países e cogitando inclusive a compra de micronações para abrigá-los.

Resguardadas as diferenças, o que o Cine Falcatrua fez foi "[...] apenas tornar público o consumo privado condicionado por essas redes" (MENOTTI, 2006) e, nesse sentido, tentar punir 0 coletivo capixaba, assim como localizar um protagonista isolado no caso do Wikileaks, Aaron Swartz, e Pirate Bay, são contra-ataques que revelam o alcance e eficácia destes enfrentamentos. Por outro lado, há indícios, em alguns dos casos mencionados, de desvio no objeto de acusação. Tanto a descabida ação movida pelas distribuidoras acusando a universidade de "concorrência desleal", sendo que as exibições eram gratuitas, quanto, no caso de Julian Assange, as incriminações formais serem diversas daquelas que extraoficialmente são imputadas ao ativista, revelam a utilização instrumental do aparato jurídico. Apesar da dissonância entre velhos paradigmas e novas ferramentas e práticas serem esquematizadas dentro de instituições, na forma de análises e registros de personalidades como Roger Chartier analisou, é na clandestinidade extrainstitucional que a gênese revolucionária acontece, não apenas em termos práticos, mas, sobretudo, teórico, uma vez que aquilo que se chama de piratas, hackers, crakers, pichadores, dentre muitos outros, é necessária a não filiação ao oficial para desenvolver suas atividades de contestação da ordem hegemônica. As instituições, portanto, se alimentam das transgressões como matéria-prima, mas não permitem seu desenvolvimento pleno. Pelo contrário, contêm-no.

Outra questão ignorada pelas instâncias oficiais é a inversão da noção de direito, não apenas como debate teórico, mas como retomada real da informação negada pelo controle econômico. 0 argumento do direito é apropriado de acordo com a situação tanto para tratar do consumo cultural quanto para justificar as ações que, em nome dos direitos do autor, caçam a liberdade de acesso por meio de taxas. Entretanto, a visão hegemônica privilegia a detenção da expansão informal da difusão da produção cultural sem os intermediários tradicionais, o que resulta em correlações moralizantes,

\footnotetext{
163 Por não possuir os direitos autorais do livro na América do Norte, a obra não foi disponibilizada justamente no país do seu autor, conforme pode ser consultado no site da editora. Disponível em: <http://www.versobooks.com/blogs?mentioned_book=3671>. Acesso em: 14 dez. 2016.

164 BAY, Pirate. About. n/i. Disponivel em: <https://thepiratebay.org/about>. Acesso em: 15 jun. 2017.
} 
construídas na indistinção entre questões díspares, tais como citadas na fala mencionada do representante da ADEPI em relação ao Cine Falcatrua. Segundo a expressão de Hannah Arendt, quando todos são culpados, ninguém o é (ARENDT, 2004), por isso, a autora ressalta que tanto a culpa quanto a inocência "[...] só fazem sentido se aplicadas aos indivíduos" (ARENDT, 2004, p.91). A manutenção difusa na massa da tomada do direito, sem a chancela impossível das instituições, gera um movimento anônimo coletivo que, embora encabeçado por um ou outro grupo, mantém o espírito de enfrentamento vivo mesmo que estes caiam diante das autoridades. Aqui, há também a figura do herói, apresentado em uma espécie de síndrome de Robin Hood, em nomeados ciberativistas como Julian Assange do Wikileaks, Aaron Swartz, e Gottrid Svartholm, Fredrik Neij e Peter Sunde do Pirate Bay. Fenômeno semelhante acontece com o reconhecimento das ações do Cine Falcatrua por esferas distintas, ainda que diretamente não tenham impactado nas decisões jurídicas. Não é possível descartar, entretanto, a hipótese que, indiretamente, a visibilidade crescente do projeto tenha de alguma forma auxiliado na decisão que finalizou o caso. As desavenças jurídicas foram encerradas em novembro de 2007, sendo que nenhum "[...] participante terminou autuado criminalmente, mas a universidade foi condenada a pagar cerca de $\mathrm{R} \$ 4.000,00$ de compensação para as distribuidoras" (MENOTTI, 2015, p.106).

Outro tributo pago à institucionalização é a suavização obrigatória das ações ásperas fora delas. Mediante as pressões ocorridas, o projeto inicial do Cine Falcatrua assumiu contorno mais definido. 0 número de participantes foi reduzido, as experimentações emancipadas de delimitações discursivas foram compelidas e ordenadas dentro de outra lógica. Lógica que, segundo pode ser apreendida das declarações do grupo, já estavam em curso antes mesmo da instauração mais efetiva das coibições ao andamento do projeto ${ }^{165}$.

Se por razões de ordem prática o Cine Falcatrua procurou inserção no circuito institucionalizado, o coletivo desenvolveu com engenhosidade "subversões" cabíveis entre suas experimentações anteriores e as possíveis dentro de uma nova conjuntura. Logo após os desdobramentos polêmicos desencadeados pela publicação da reportagem no jornal Folha de $S$. Paulo, o coletivo promoveu debates públicos sobre o processo, não deixando, entretanto, de ironizar sua própria história, expondo em seu fotolog apoios reais ou mesmo fictícios (ao que tudo indica) ao projeto. Publicaram, por exemplo, o agraciamento que teriam recebido do consagrado artista francês

\footnotetext{
165 Em entrevista, realizada em 2013, os integrantes do Cine Falcatrua (Fabrício Noronha, Rafael Trindade e Gabriel Menotti), afirmaram que ocorreu uma mudança radical no projeto nesse período. Mudança que já estava sendo elaborada com o objetivo de fomentar o projeto, já que mesmo a utilização dos equipamentos pertencentes à UFES não ocorria de forma tranquila. Segundo relatou um dos integrantes, em uma das sessões, a Diretora do CCJE (Centro de Ciências Jurídicas e Econômicas) ao qual, o curso de Comunicação Social fazia parte, interrompeu uma das exibições com queixas e ameaças (SEGATTO; LOPES, 2013), evidenciando uma situação de tensão entre as partes.
} 
Yves Jacques Sans-Soutiens (o sobrenome do suposto artista une as palavras sans - sem - e soutiens - sutiã -, que na tradução literal seria sem suporte, remetendo, possivelmente, a situação que estavam vivenciando e, de forma maliciosa, à ausência dessa peça íntima da indumentária feminina), não desfazendo ou esclarecendo as opiniões de seus seguidores. Cabe ressaltar que, alguns apoiadores do projeto, na sessão de comentários no fotolog do coletivo, manifestaram entusiasmo com a homenagem internacional em forma de cartaz, chegando mesmo a afirmar que o fato causaria inveja ao jornal paulista (FALCATRUA, 2004). Alguns diretores, entre eles, Cláudio Assis 166 e Paulo Sacramento ${ }^{167}$, disponibilizaram seus filmes para exibição, sendo que outros mandaram mensagens de apoio ao projeto 168 .

Individualização e responsabilização são outras formas de controle do sistema instituído. Ao tornar pública uma prática já disseminada no âmbito privado ${ }^{169}$, bem como, o fato de o projeto estar sendo desenvolvido dentro de uma instituição de ensino conhecida, permitia às entidades em questão (a ADEPI e as distribuidoras Lumière e Europa filmes) promoverem ações concretas de coibição social com base jurídica, além das simples - e, certamente, inócuas - campanhas moralizantes que executavam ${ }^{170}$. Por um lado, dentro da própria universidade, enquanto a reitoria "[...] pretendia colocar toda a culpa nos participantes do cineclube, como se eles tivessem não apenas cometido um crime,

166 Cláudio Assis, conhecido por suas críticas ao sistema de distribuição de filmes pelas empresas multinacionais, não somente disponibilizou a exibição de Amarelo Manga (2002), mas comentou em entrevista ao jornal capixaba Século Diário (13/09/2004), a importância de o projeto discutir outras possibilidades de uso do cinema enquanto cultura e não como mercado. Segundo consta no fotolog do Cine Falcatrua, o diretor afirmou: "Esses monstros da indústria cinematográfica estão processando alunos de uma universidade!!! Esses caras querem ser donos do mundo, mas não são donos de nada!". Ressalta-se que o jornal online Século Diário, retirou o link com a reportagem mencionada.

167 O cineasta Paulo Sacramento, em apoio ao projeto, disponibilizou a exibição do documentário 0 prisioneiro da grade de ferro (2003), que apesar de ter estreado no circuito nacional no início de 2004, estava sem previsão de exibição no Espírito Santo. Para realizar o documentário, oficinas e cursos técnicos de câmera e som foram desenvolvidos com os detentos do Carandiru, que retrataram o cotidiano no presídio, um ano antes de sua desativação. Sobre o documentário, consultar: VALDATI, Nilcéia. É tudo verdade! Testemunho e experiência em 0 prisioneiro da grade de ferro (autorretratos). Crítica Cultural - Critic, Palhoça, SC, v. 10, n. 1, p. 109-117, jan.jun. 2015. Disponível em: $<$ http://linguagem.unisul.br/paginas/ensino/pos/linguagem/critica-cultural/1001/100108.pdf>. Acesso em: $10 \mathrm{dez} .2016$.

168 Consta no fotolog do grupo que, desde a emissão da liminar movida contra a UFES pelas distribuidoras Lumière e Europa filmes alegando concorrência desleal, Cineclubes, organizações e diretores de cinema de várias partes do país, manifestaram apoio ao projeto. Entre os diretores de cinema, destacam as manifestações de apoio de Cláudio Assis (Amarelo Manga), Katia Lund (codiretora de Cidade de Deus), Marcelo Masagão (1,99 Supermercado de Palavras), Anna Muylaert (Durval Discos), Anna Azevedo (Rio de Janeiro) e Paulo Sacramento (FALCATRUA 2004).

${ }_{169}$ Ressalta-se que também os equipamentos utilizados pelo grupo eram caseiros: "CPUs obsoletas, data-show, amplificadores, uma tela branca e cabos, muitos cabos" (MENOTTI, 2006, p.165).

170 Muitos são os exemplos dessas campanhas moralizantes, incluindo desde vídeos que antecediam as sessões de cinema, nos quais, a cópia ilegal era associada ao crime organizado - relação nunca explicada com base em fontes de pesquisa - até reportagens televisivas que proclamam números alarmantes sobre os prejuízos que a indústria da pirataria trazia às arrecadações governamentais, mesclando dados e práticas distintas do que classificam como pirataria. "Qual é a relação entre a falsificação de um relógio, a falsificação ou contrabando de remédios, o contrabando de videogames e a pirataria de software?", para Rosana Pinheiro Machado, a diferença "não está sob o aspecto legal nem formal, mas moral: piratear remédios pode matar, falsificar relógios não" (CORNILS, 2010, p.57). Sem mencionar os boatos de que os usos de mídias piratas estragariam o aparelho, disseminados, sobretudo no início do século XXI, quando a ingenuidade no uso tecnológico era generalizada. 
mas também traído a confiança da instituição" (MENOTTI, 2015, p.106), por outro, alunos e professores defendiam o projeto por entenderem que "[...] a universidade deveria ser livre para investigar e experimentar com tecnologias alternativas de distribuição cinematográfica" (MENOTTI, 2015, p.106), enquanto membros da sociedade civil manifestaram apoio ao projeto, argumentando sobre 0 "[...] direito universal de acesso à cultura" (MENOTTI, 2015, p.106)171. Esta disparidade é evidente e circunscrita ao âmbito do esperado, mas é útil como dado para a condução de duas questões salutares, uma voltada à escolha do terreno de embate político, associado ou apartado das instituições, e a outra, voltada à noção ampla de direito, por vezes, contraditória.

Quanto mais livre, distante, apartada ou independente das instituições representativas do sistema combatido, sejam elas físicas ou simbólicas, maior será a autonomia crítica. Isto é, os dirigentes das instituições, comprometidos por laços jurídicos passíveis de responsabilização severa, tem sua atuação acusatória determinada pelo alto vínculo com a instituição, enquanto estudantes, professores e sociedade civil, apoiadores das ações do grupo, estão mais isentos de responsabilização e tem maior autonomia na defesa de atos considerados ilegais pela legislação. A categoria de vínculo institucional, portanto, ao contrário do que alguns pretendem negar, determina também o grau de autonomia possível dentro do jogo político da cultura e da arte.

A descrença na possibilidade de práticas artísticas continuarem a desempenhar um papel crítico na atualidade dentro do domínio tradicional das instituições, cada vez mais condicionadas pelos interesses do capital, é associada por Chantal Mouffe (MOUFFE, 2013)172 ao desenvolvimento das indústrias criativas - visto que a produção simbólica adquiriu centralidade - , sendo que artistas, produtores e consumidores da cultura passaram a exercer funções cada vez mais passivas no sistema capitalista. Rejeitando o pessimismo desse diagnóstico, a autora defende a necessidade de comprometimento com as instituições, ponderando, entretanto, que isso não significa relegar as práticas artísticas ao domínio tradicional do mundo da arte. Para Mouffe, o abandono do terreno institucional não contribui para as lutas contra hegemônicas, assim, ela reforça a importância do papel das práticas artísticas críticas dentro destes ambientes. Elas precisariam se envolver nele com "[...] 0 objetivo de fomentar a dissidência e criar uma multiplicidade de espaços agonísticos, no lugar em que 0 consenso dominante é desafiado e novos modos de identificação são disponibilizados" (MOUFFE, 2013).

\footnotetext{
171 A divisão proposta pelo autor, entre os apoiadores ou opositores ao projeto, é evidentemente generalizada. 172 MOUFFE, Chantal. Artistic Strategies in Politics and Political Strategies in Art. E-MISFÉRICA. DISSIDÊNCIA. Vol. 10 | N. 2 - 2013. Disponível em: <http://hemisphericinstitute.org/hemi/pt/e-misferica-102/mouffe>. Acesso em: 16 out. 2015.
} 
Quero deixar claro que não estou discutindo a favor de uma concepção puramente institucional da política ou para relegar as práticas artísticas críticas para o domínio tradicional do mundo da arte, mas para uma articulação dos diferentes modos de intervenção política em uma multiplicidade de lugares. Existe uma grande variedade de formas possíveis para fazer emergir espaços agonísticos desafiando o consenso dominante, podendo surgir tanto dentro quanto fora das instituições. [...].

Os museus, por exemplo, podem, sob certas condições, proporcionar espaços para uma confrontação agonística, e é um erro acreditar que os artistas que optam por trabalhar com eles não podem desempenhar um papel crítico e que são automaticamente recuperados pelo sistema (MOUFFE, 2013).

Certamente é possível haver crítica formulada por artistas e diretores dentro dos museus e universidades, entretanto, seguindo o caso do Cine Falcatrua, sua potência será fatalmente filtrada. Diante disso, é possível identificar um padrão na atuação crítica: a institucionalização requer meios indiretos de contraposição, enquanto que meios diretos são possíveis apenas com ampliação da autonomia. Ao centrar esforços em afirmar a necessidade de haver múltiplos espaços de discussão e embate, contrapondo-se à saída das instituições como única alternativa viável, Chantal Mouffe, nesse texto, evita questões que trariam maior complexidade à discussão: qual o grau de autonomia possível quando existe o vínculo institucional? O quanto o ativismo institucional é amenizado por este vínculo?

A transposição do debate sobre os benefícios da vinculação ou desvinculação institucional na potencialização do grau de contestação hegemônica, entretanto, para ambientes não estruturados tem sua premência amenizada ou adquire nuances diversas das que ocorrem nos grandes centros. Nos grandes centros do capitalismo, com o cenário artístico composto por um sistema estruturado formado por aparelhos culturais (museus, galerias, centros culturais etc..), mercado de arte e reflexão crítica - a contestação ao hegemônico, dentro ou fora das instituições, parece uma alternativa possível ou mesmo necessária. Por um lado, o artista crítico independente, por dispor de outras vias de manutenção de seu trabalho, encontra eco, positivo ou negativo, no cenário apresentado acima. Por outro lado, as instituições são capazes de fomentar, gerir e divulgar seus próprios aspectos críticos por sua resistência como corpo perene.

Não é à toa, portanto, que questões diversas à contestação da hegemonia institucional pautem a produção contemporânea de cidades de menor porte, como é o caso de Vitória (ES). O panorama do qual Chantal Mouffe parte pressupõe um sistema das artes consolidado, no qual, a oposição ao ambiente parece ser uma alternativa viável ou mesmo necessária à expansão e ou manutenção do status quo. Porém, em locais à margem do cenário que engendrou a discussão proposta pela autora, a questão que move a aproximação com os espaços institucionais pelos artistas engajados em práticas mais experimentais é pautada, sobretudo, pela necessidade de viabilizar suas produções, para as quais a relação com as organizações pode figurar como acessório fundamental. É o que pode ser 
apreendido da relação dos coletivos Maruípe, Entretantos e Cine Falcatrua com o circuito artístico capixaba.

Por vias diversas e adotando marcos temporais distintos, duas publicações brasileiras - a primeira focada no cenário artístico nacional entre os anos de 1960 e 1970 e, a segunda entre o final da década de 1990 e anos iniciais do século XXI — apontam para os limites de estabelecer uma postura crítica mais radical dos artistas brasileiros em relação às instituições culturais. Como toda regra, é claro, exceções podem ser detectadas, porém, a recorrência sinaliza que a relação entre instituições e artistas, na periferia do capitalismo, muitas vezes adquire contornos singulares, considerando que construção e tentativa de superação não são, necessariamente, excludentes.

Um desses estudos é o livro Anna Bella Geiger: passagens conceituais de Dária Jaremtchuk (JAREMTCHUK, 2007a), originalmente sua tese de doutorado. A autora, ao fazer uma síntese e contextualizar o debate entre práticas experimentais e circuito instituído no eixo Rio-São Paulo entre as décadas de 1960 e 1970, afirma que, apesar de os artistas voltados para as práticas experimentais e reflexivas questionarem as debilidades do sistema e seus anacronismos, não adotaram postura radical contra as instituições artísticas como os seus pares norte-americanos e europeus. Segundo Jaremtchuk, eles, ao "[...] contrário, buscaram o fortalecimento do sistema porque inexistia um modelo consolidado e fortemente estabelecido no país" (JAREMTCHUK, 2007a, p.42). Por seu turno, Priscila Rossinetti Rufinoni, analisando o estudo de Jaremtchuk, destacou a abertura da Galeria Global (pertencente à Rede Globo) ${ }^{173}$ em 1975, durante um dos períodos mais repressivos da ditadura militar no Brasil (RUFINONI, 2009a) ${ }^{174}$ e, evocando o trabalho de Annateresa Fabris ${ }^{175}$, lembrou a aquisição da produção de Cândido Portinari pelo Governo Vargas (RUFINONI, 2009a), para sublinhar que nas artes plásticas "não houve repressão acirrada e visível como em outras áreas" (2009a, p.159), isso porque sua "'popularidade' nunca foi a mesma da música ou do teatro, forma popular à época" (2009a, p.159). Nesse sentido, vale sublinhar, que as institucionalizações podem variar: a aproximação entre

\footnotetext{
173 Remetendo à pesquisa de Dária Jaremtchuk, Priscila Rufinoni, informou que a Galeria Global, expôs, dentre outros, Antonio Manuel, Nelson Leirner, Ivald Granato e Anna Bella Geiger. Destacando também, que as mostras eram acompanhadas de chamadas publicitárias na televisão. "Imagens dos trabalhos e depoimentos dos artistas iam ao ar nos horários comerciais [...] após algumas discussões e ameaças de censura, aceitou exibi-las somente após o horário nobre" (JAREMTCHUK apud RUFINONI, 2009, p.159).

174 Denominado de "Anos de chumbo", fazendo referência, especialmente, ao período que Emílio Garrastazu Médici foi presidente do Brasil (1969-1974). Esta fase, entretanto, foi iniciada, com a edição do Al-5 (1968) e, reverberou em anos posteriores. RUFINONI, Priscila R. Anos 70: oposições e inserções artísticas. Concinnitas. Rio de Janeiro. Vol. 1, p.156160, 2009a.

175 A autora faz referência ao livro Portinari, pintor social (1990). Neste, Annateresa Fabris destacou a indiferença de Getúlio Vargas pelas artes plásticas, "tanto que toda a política artística do período tem como mentor Gustavo Capanema, apaixonado pela 'arte nova'" (1990, p.31). "Em seus inúmeros discursos, o presidente não faz nunca menção às artes plásticas, enquanto enfatiza com insistência o papel desempenhado pelo rádio e pelo cinema na consolidação da nacionalidade" (1990, p.32). FABRIS, Annateresa. Portinari: pintor social. São Paulo: Perspectiva: Editora da Universidade de São Paulo, 1990.
} 
instituições deve levar em conta certas diferenciações de atuação no campo artístico (museus, galerias etc.) e nas esferas mais rarefeitas, nas quais, universidades e Estado fazem às vezes do meio institucional. $\mathrm{O}$ apoio ao campo artístico crítico feito pela Rede Globo em plena ditadura ou a indiferença de Vargas às proposições de Portinari, também podem ser pensados de forma semelhante, pois exemplificam o caráter mais hermético dessa produção em relação a outras manifestações culturais de oposição, resultando em uma repressão menos implacável. Tanto assim que, conforme destacou Rufinoni (2009a) nas análises mais gerais do período da ditadura militar no Brasil que abordam cultura e política - entre as quais, o texto clássico de Roberto Schwarz Cultura e política, 1964-69 (1978)176 e Literatura e vida literária. Polêmicas \& retratos de Flora Sussekind (1985)177 - as artes plásticas não são mencionadas.

O segundo trabalho é a dissertação de Fernanda Albuquerque (ALBUQUERQUE, 2006), que analisou coletivos de artistas no Brasil entre 1995 e 2005. Segundo a autora, apesar de alguns desses grupos e outras iniciativas coletivas assumirem uma posição crítica e propositiva perante as dinâmicas de produção, circulação e legitimação do sistema artístico, tal postura é também assinalada por dualidades, não refletindo necessariamente uma colocação anti-institucional ou antissistema, expressando uma forma de resistência mais afirmativa do que de negação. A crítica e a contraposição, em escalas distintas, serviam algumas vezes como estratégia de inserção que possibilitasse visibilidade e trânsito no sistema. Para a autora, entretanto, isso não significou que alguns desses grupos não procurassem ampliar as discussões relativas à criação e inclusão da arte na sociedade. É nesse sentido que Fernanda Albuquerque detectou uma atitude mais crítica em relação ao sistema das artes e suas dinâmicas de circulação, uma vez que tecer relações com um público mais amplo, inserindo-se em espaços e situações do cotidiano, possibilitava a esses coletivos atuarem de maneira mais direta na realidade social.

Se a arte atua de forma crítica ou alheada, o poder dificilmente é incomodado por ela. Portanto, se o confronto ameno ou ambíguo às instituições no Brasil não é novo, reforçando um panorama já delineado em pesquisas anteriores, a questão toma contornos amplificados quando direcionada especificamente às suas subperiferias, pouco beneficiadas pelas Leis de Incentivos Fiscais que, a partir dos anos de 1990, foram paulatinamente condicionando a produção e difusão cultural e artística brasileira aos interesses do capital. Vale ressaltar, que entre 2003-2008, a região sudeste captou $80 \%$ dos recursos da Lei Rouanet. Destes, apenas 1\% foi captado pelo estado do Espírito Santo, aproximando os índices capixabas aos da região norte, região menos privilegiada do país em relação à

176 SCHWARZ, Roberto. Cultura e política, 1964-1969. In: 0 pai de família e outros estudos. Rio de Janeiro: Paz e Terra, 1978.

177 SUSSEKIND, Flora. Literatura e vida literária. Polêmicas \& retratos. Rio de Janeiro: Zahar, 1985. 
distribuição dos recursos das Leis de Incentivo Fiscal (GRUMAN, 2011; 2010)178. No caso das artes visuais, em cidades de menor porte, situadas fora do eixo hegemônico brasileiro, o reflexo dessa distribuição desigual dos recursos pode ser detectado no tipo de benefício recebido, quase sempre restrito a abrigar exposições prontas vindas dos grandes centros ${ }^{179}$.

Dessa forma é possível retornar à questão evitada por Chantal Mouffe: qual o grau de autonomia possível quando existe o vínculo institucional? (mesmo considerando que esse vínculo adquira nuances diversificadas em instâncias distintas). Ambas as posturas, tanto as mais agudas encontradas nos grandes centros quanto as conciliatórias verificáveis nas periferias são consequências possíveis de acordo com o seu contexto. A primeira é viável por conta da estrutura formada e demanda por crítica feita pela própria disciplina. A segunda, em ambientes ainda precários, as instituições não suportariam críticas mais contundentes (ou acabariam por integrá-las, operando pelo avesso e mimese, em processo semelhante ao efetuado por algumas iniciativas independentes, conforme foi visto), decorrendo daí, certa afasia ou abstenção consciente nas oposições com o intuito - talvez seja possível supor - de preservação. Ambas, entretanto, simulam confrontos, nas quais, rupturas efetivas são, de fato, raras ou inexistentes.

\subsection{INTANGIBILIDADE/INVISIBILIDADE}

A procura por emancipação e termos correlatos - como protagonismo e participação coletiva - permearam as atividades de diversos agrupamentos no início do século XXI e levaram à aspiração de realizar de forma autônoma empreendimentos alternativos virtuais ou físicos. As ações desses grupos em Vitória - nos exemplos aqui analisados - , embora de formas distintas, foi transpassada pelo anseio por autonomia presente, especialmente, na elaboração e condução de seus próprios eventos, de forma mais distendida ou limitada a participantes externos. Neste sentido, o coletivo Maruípe optou por uma construção coletiva e acessível a qualquer interessado no Paralela-ao-mar, ao passo que o Entretantos nas duas edições do multipliCIDADE não efetuou uma discussão em canal aberto na construção do projeto. De maneira semelhante ao Entretantos, o Cine Falcatrua também

178 GRUMAN, Marcelo. Incentivos Fiscais para as Artes: balanço histórico e perspectivas futuras. II Seminário Internacional de Políticas Culturais, 2011. GRUMAN, Marcelo. Nem tanto ao céu, nem tanto a terra: limites e possibilidades da lei de incentivo fiscal à cultura. Revista Espaço Acadêmico, v. 9, n. 107, p.149-154, 2010.

$179 \quad$ No artigo Dinamismo e crise dos museus de arte do Brasil (2006), Moacir dos Anjos, analisa as múltiplas e contraditórias implicações nas instituições de arte do país do modelo de financiamento público da cultura que foi adotado a partir dos anos de 1990, em "uma época de internacionalização do capital econômico e simbólico" (2006). Em relação às cidades de menor porte, o autor sublinhou que, no melhor dos casos, a circulação dessas exposições prontas auxiliava na ampliação do repertório visual dos habitantes, não contribuindo, porém, para que as instituições adquirissem autonomia para desenvolver seus próprios projetos, formularem e enunciarem "um discurso crítico em relação à produção artística contemporânea" (2006). ANJOS, Moacir dos. Dinamismo e Crise dos Museus de Arte no Brasil. Revista Z Cultural (UFRJ), v. 1, 2006. 
mantinha seus canais sobre os eventos mais para divulgar suas atividades do que como meio de interferência aberta à estruturação de suas ações.

Replicando, substituindo ou associando-se ao modelo institucional o potencial contestatório que impulsionou ações conjuntas nesse período, de forma ampla, é atenuado quando analisado a partir de alguns pontos. Assim, considerando essas ações como reações à ausência de uma atuação mais efetiva do Estado, elas correm o risco de se tornarem meros apoios, quando não fomentos, à negligência estatal (alentando, entretanto que, em meios mais complexos, não é apenas o Estado que se pode chamar de instituição). Nesse sentido, o slogan "faça você mesmo" serve tanto para pensar sobre o espírito alternativo presente no universo hacker quanto no pálido movimento de caráter otimista e resiliente do voluntarismo, afinado com a retórica dos discursos neoliberais e suas estratégias de terceirização e inovação associadas à cultura e aos recursos humanos na promoção do senso comunitário. Especificamente, no campo artístico, conforme analisou, dentre outros, Fernanda Maio (2011) ${ }^{180}$ o interesse dos artistas pelos aspectos sociais, a partir da década de 1990, não pode ser dissociado das alterações nas políticas culturais e de apoio às artes no âmbito europeu. Conforme ressaltou a autora: "Pretende-se agora que os artistas façam obras de arte vistas como socialmente úteis, ou susceptíveis de alargar o seu público-alvo" (2011, p.9). Assim, para ela, dentro desse novo contexto, ainda que reverberem na produção dos artistas, questões discutidas pelas práticas experimentais realizadas nas décadas anteriores, há uma distinção que não pode ser ignorada: "O artista-intelectual dos anos sessenta torna-se o prestador de serviços nos anos noventa" (2011, p.25).

Boris Groys (2008) ${ }^{181}$, por sua vez, ao analisar as mudanças nas artes no período posterior à Guerra Fria, examinou a arte moderna e a contemporânea a partir de sua função ideológica, como mercadoria ou ferramenta de propaganda política. Assim, para ele, nas últimas décadas a arte cada vez mais tem sido produzida e exibida conforme as normas da propaganda ideológica, com a expansão de grandes exposições internacionais, bienais e festivais, posicionando-se concomitantemente como imagem e crítica da imagem. Diversamente, portanto, de uma série interpretações correntes, Groys defendeu que a arte impulsionada ideologicamente não é uma coisa do passado: "A arte atual nas bienais e trienais também é feita para ser exibida para as massas, para aqueles que não necessariamente irão adquiri-las, os não compradores constituem a esmagadora maioria do público" (GROYS, 2008, p.7). Para ele, o fetiche da arte está ocorrendo fora dos museus, "obras agora são icônicas não como um resultado de uma exposição no museu, mas por sua circulação no mercado de

180 Ressalta-se que o livro foi originalmente a tese de doutorado da autora. Com o título de Performing art: reinventing avant-garde practice and the role of the artist foi realizada no Goldsmiths College, University of London, Reino Unido, em 2004. MAIO, Fernanda. A encenação da arte. Leiria: Textiverso Lda, 2011, p.9.

181 GROYS, Boris. Art Power. London: The MIT Press, 2008. 
arte e nos meios de comunicação de massa" (2008, p.46). A democratização da audiência na arte, tão evocada em tempos mais recentes, é questionada por Groys: "[...] toda a arte de vanguarda foi realizada contra o gosto corrente e, especialmente do público". Assim, a recente noção pedagógica, para ele, também não é uma resposta condizente, posto que "toda boa arte sempre foi e ainda é realizada contra qualquer tipo de regras apresentada pela educação" $(2008$, p.6).

No plano da instrumentalização recursiva na cadeia artística o potencial contestatório revela-se frágil ao tentar promover abalos efetivos no sistema ${ }^{182}$. De forma semelhante, o discurso que apregoa a participação forjando redesenhar o papel do público que, de espectador, é alçado à coautor, é pouco credível ou mesmo refutável. Salvo quando opta por vontade própria a participar, é possível pensar que sua função anterior de espectador nos espaços culturais, por mais passível que fosse, pressupunha uma escolha. $O$ transeunte capturado nas ruas, na maior parte das vezes, sequer possui noção do que se passa. A audiência, portanto, figura como espectadora e material simultaneamente quando é realizada de forma voluntária, como pode ser observado com os participantes/auxiliares do Cine Falcatrua, GNU/Linux, Wikileaks, Wikipédia etc., desejosos e conscientes do seu papel. Por outro lado, o espectador continua a ser o mesmo de sempre. Iniciado o suficiente para querer se confrontar com 0 trabalho artístico, constitui-se em figura própria e clássica da disciplina. Componente novo, portanto, é o indivíduo-material da obra que, inconsciente de sua posição, é coisificado sem licença, nem crédito. Em todo caso, a relação instrumentalizada entre o artista e seu público, espectador ou coisa inconsciente, é instrumental, pois, no primeiro caso, tolera apenas o divisado pela tradição nova ou velha, servindo como suporte ou cliente, e, no segundo caso, é tratado como objeto alienado do processo.

Outra forma de atenuação das atividades independentes no campo institucional é aquela relativa à expansão do caráter virtual dos empreendimentos. Se a origem desses agrupamentos seguiu a mesma lógica das instituições, isto é, em torno dos meios de reprodução - equipamentos, mão-deobra, know how, visibilidade e legitimação —, o franco acesso a tais recursos tem tornado obsoleta a existência física não apenas destas organizações, mas também a própria raison d'être de algumas instituições. Não por acaso, dia-após-dia, aquilo que tinha sede, encontra sua existência acessível apenas via webpage por questões de praticidade e economia. Inúmeros são os exemplos: lojas, serviços, agremiações, revistas científicas, eventos, encontros, trabalhos coletivos etc.. Particularmente interessantes para o caso em questão são as agremiações em torno de temas dedicados, por exemplo,

\footnotetext{
182 Até porque o potencial contestatório já é parte do sistema, quando se considera que a arte contemporânea deriva do gesto de Marcel Duchamp que, ao apresentar seus ready-made, indagou, dentre outras questões, sobre a singularidade da obra de arte diante dos objetos do cotidiano e do ato eletivo do artista.
} 
a pornografia, aos jogos, memes, culinária, literatura, música, que migraram dos encontros presenciais para as plataformas disponíveis na internet. Qual a relevância ou visibilidade dos coletivos artísticos diante deste infinito catálogo de interesses instantaneamente acessíveis? Aparentemente, tanto no mundo físico, quanto no mundo virtual, os agrupamentos são relevantes somente quando desafiam a mainstream, sob pena de, no primeiro caso, constituírem-se em instituições precárias, e, no segundo, perderem-se nas infinitas possibilidades da rede.

A autoridade da disciplina artística, por sua vez, constitui outro tipo de barreira de contenção do potencial contestatório das ações coletivas. Como pode ser observado no caso do Cine Falcatrua, o movimento foi realizado de fora para dentro da disciplina, na qual a instrumentalização procurou de certa forma guarida na arte para suas ações passíveis de penas reais, implicando na suavização do vigor crítico anterior. De modo diverso, as atividades dos coletivos Maruípe e Entretantos demonstraram a movimentação de dentro para fora, revisitando ou adotando estratégias do campo disciplinar da arte na procura de visibilidade e expansão das fronteiras. Em todos os exemplos, seja pela necessidade de viabilização de seus projetos, sobrevivência ${ }^{183}$ ou a atualização com as mudanças em curso, o fetiche pela extradisciplinaridade e a glamorização do artista como outsider acabam esmaecidas. Flexibilidade, transversalidade e transitoriedade se tornam quase sinônimos de desalento, tanto para o artista no meio ativista quanto para o ativista no meio artístico quando as críticas são incorporadas como necessárias ao jogo disciplinar, ou seja, quando passam a serem encenações de transgressões mais efetivas.

\footnotetext{
183 A necessidade por sobrevivência se torna mais nítida quando o artista recorre ao meio acadêmico como refúgio empregatício e até lugar possível para o desenvolvimento de práticas pedagógicas com intuito crítico, como é o caso do projeto Arte de Conducta (2002-2009) da artista cubana radicada nos Estados Unidos, Tania Burguera. Diversamente do panorama mais recente, cabe lembrar a frase emblemática de Ivald Granato, impressa em um panfleto, em 1977: "Adote o artista não deixe ele virar professor". Corroborando com essa frase é necessário sublinhar que parte considerável dos artistas da vanguarda brasileira dos anos de 1950 e 1960 não frequentou cursos regulares de arte, mas aqueles oferecidos nos ateliers de artistas ou por museus, conforme pode ser apreendido consultando os verbetes com as biografias que constam em estudo realizado por Fernando Cocchiarale. Cf: COCCHIARALE, Fernando. Abstracionismo geométrico e informal: a vanguarda brasileira nos anos cinquenta. Rio de Janeiro: FUNARTE, 1987, pp.262-278. Em relação ao trabalho de Tania Burguera consultar o site da artista. Disponível em: <http://www.taniabruguera.com/cms/>. Acesso: 12 jul. 2015.
} 


\title{
CAPÍTULO 2
}

\section{CONSTRUINDO NAS BRECHAS}

\begin{abstract}
Exagera os méritos, é óbvio, concentrando neles toda a luz, mantendo criteriosamente na sombra o que é menos glorioso, apagando mesmo o que possa deslustrar a imagem. Era essa uma das funções dessa literatura [...] heroicizando [...] mediante a exaltação das supostas virtudes, todos os rumores que podiam correr em detrimento de sua fama (Georges Duby). ${ }^{184}$
\end{abstract}

Tanto por parte de artistas quanto por instituições e formuladores de políticas culturais, realizar mostras fora dos espaços expositivos convencionais e a proposição de ações interventivas, participativas ou colaborativas com outros artistas ou com o público foram pontos de interesse crescente a partir da década de 1990. Em Art and public space: questions of democracy (1992), Rosalyn Deutsche, afirmou com ironia, que: "A julgar pelo número de referências ao espaço público no discurso estético da contemporaneidade, o mundo da arte tem "levado a democracia a sério"' (1992, p.34) ${ }^{185}$. A autora detecta que a terminologia arte pública parece congregar um "[...] compromisso não só com a democracia como forma de governo, mas a um espírito democrático geral de igualdade" (1992, p.34). Utilizando, a controvérsia gerada pela obra Tilted Arc de Richard Serra como exemplo, Deutsche constata que ideais democráticos foram evocados por aqueles que defendiam sua permanência na Federal Plaza de Nova York, pelos que tentaram aplacar o conflito sem tomar partido e ainda por autoridades do governo na ocasião de sua remoção, em 1989 (DEUTSCHE, 1992, p.34 e 35).

Rosalyn Deutsche foi uma das pioneiras em analisar a intersecção entre arte pública e política urbana, desenvolvendo ferramentas críticas que serviram de eixo para análises posteriores, entre as quais, a empreendida por Miwon Kwon (2002) para reavaliar as maneiras acríticas que o termo sitespecific estava sendo utilizado tanto na retórica do vanguardismo estético quanto pela tendência política progressista. $\mathrm{Na}$ introdução do livro One place after another: site-specific art and locational identity (2002) ${ }^{186}$, Kwon afirmou que situou as questões relativas à implantação da arte como uma

\footnotetext{
184 DUBY, Georges. Guilherme Marechal, ou o melhor cavaleiro do mundo. Rio de Janeiro, Graal, 1987, p.53.

185 DEUTSCHE, Rosalyn. Art and Public Space: Questions of Democracy. Social Text. Duke University Press. n. 33 (1992), pp.34-53.

186 Cabe sublinhar que, a revisão efetuada por Miwon Kwon das práticas artísticas contemporâneas associadas à noção de site specificity considerou a diversidade de relações entre obra de arte e seu contexto, discutindo tanto os problemas críticos, estéticos e éticos, quanto noções contemporâneas de esfera pública, lugar, identidade e comunidade.
} 
problemática do espaço político, considerando aquilo que Rosalyn Deutsche denominou de um discurso urbano-estético ou espaço-cultural que relaciona "[...] ideias sobre arte, arquitetura e design urbano, por um lado, com teorias da cidade, espaço social e espaço público, por outro" (2002, p.2 e 3). Para a autora, a expansão de termos novos para explicar as diversas permutações da arte site specific nas últimas décadas sinaliza tanto para a tentativa de recuperar o caráter anticomercial de práticas desenvolvidas nos anos de 1960 e 1970 quanto para o desejo de distingui-las das do passado (2002, p.1). Ressalta-se que a literatura mais abrangente relacionada ao assunto foi produzida no contexto norte-americano ${ }^{187}$, sobretudo, a partir da década de 1990, com as contribuições, além das autoras mencionadas, dentre outros, de Tom Finkelpearl, Suzanne Lacy, Nina Felshin, Grant Kester e Hal Foster que revisaram perspectivas, formaram marcos interpretativos distintos e uma base crítica para analisar essas produções mais recentes. No final da década de 1990, aportes expressivos foram desenvolvidos na Europa e, a partir dos anos de 2000, esses quadros teóricos embrenharam-se nas discussões internacionais.

As reconfigurações do que tradicionalmente se convencionou denominar arte pública ao longo das últimas décadas, com a expansão de seu espectro para além da noção de arte/objeto em lugares públicos, abrangendo e incorporando ações que envolvem arte e comunidade começaram a ser debatidas com maior afinco no Brasil no começo dos anos de 2000. A ressonância do tema "Iconografias Metropolitanas" na 25a Bienal - inaugurada em 24 de março de 2002 - e a recepção ao evento Arte/Cidade Zona Leste ${ }^{188}$ - aberto em 16 de março de 2002 - motivaram a revista Trópico a

187 Embora, Miwon Kwon neste livro - que foi sua tese de doutorado, defendida no final dos anos de 1990, na Universidade de Princeton - tenha desenvolvido uma discussão profícua e revisado com acuidade aspectos históricos do termo e suas implicações para a especificidade local nas práticas críticas, curatoriais e artísticas, os exemplos discutidos ao longo do trabalho são norte-americanos, salvo raras exceções de artistas europeus, como por exemplo, Daniel Buren. Ao adotar o contexto ao qual estava inserida como paradigma geral, a autora não explicitou, como o fez em algumas ocasiões Hal Foster, os limites de sua abordagem. Na introdução de Bad News Days: Art, Criticism, Emergency (2015, p.8), por exemplo, ele afirmou que todos os seus exemplos seriam da América do Norte e Europa Ocidental. Cf: FOSTER, Hal. Bad New Days: Art, Criticism, Emergency. London/New York: Verso Books, 2015.

188 Em 2002, o Projeto Arte/Cidade realizou sua 4a edição, denominada Arte/Cidade Zona Leste. Iniciado em 1994, com o subtítulo de Cidade sem janelas, o evento aconteceu no Matadouro Municipal da Vila Mariana, em São Paulo. A edição seguinte, denominada de $A$ cidade e seus fluxos ocupou o topo de três edifícios na região central de São Paulo. Em 1997, A cidade e suas histórias utilizou a estação de trens (Estação da Luz) e um trecho ferroviário que perpassava locais "significativos do período fabril da cidade de São Paulo: os silos do antigo Moinho Central, e os galpões e chaminés que restam das Indústrias Matarazzo". O percurso do público era realizado de trem e as "intervenções voltaram-se para a grande escala deste recorte, com suas áreas inacessíveis à observação ocular e desconectadas da organização urbana da metrópole atual. "Na edição de 2002, a opção foi fazer o evento na região leste de São Paulo, lugar de imigrantes e do início da industrialização da cidade. Na época do evento, a região estava sendo ocupada por condomínios residenciais e corporativos, intercalados com ocupações informais de moradia e comércio de rua. As informações acima constam no site do projeto Arte/cidade. Disponível em: http://www.artecidade.org.br/indexp.htm. Uma análise detalhada das edições realizadas pelo Arte/Cidade, entre 1994 e 2002, foi realizada por Gabriel G. E. de Souza. Ver: SOUZA, Gabriel Girnos Elias de. Percepções e Intervenções na Metrópole: a experiência do Projeto Arte/Cidade em São Paulo (1994/2002). Dissertação (Mestrado em Engenharia) Escola de Engenharia de São Carlos, São Carlos, 2006. 
indagar para artistas, curadores, jornalistas etc. 189 "O que é arte pública?". Na introdução das respostas recebidas, Lisette Lagnado ressalvou que, apesar da questão não ser nova, a procura por uma participação mais efetiva nos problemas sociais estava mobilizando artistas e curadores. $O$ resultado da enquete foi publicado em abril de 2002, na seção Em obras da revista. Nesta, a organizadora afirmou detectar:

[...] uma confusão entre as definições de monumento público e intervenções urbanas, modelos de exibição da arte e papel do arquiteto, dilema entre espaços institucionais e 'novos espaços', democratização do acesso à cultura e reconhecimento da presença de agentes mercadológicos.

A reivindicação, contudo, é clara: trata-se de uma vontade de deselitizar a produção artística, abrindo-a para a participação coletiva, em resposta aos intoleráveis processos de exclusão em curso na sociedade contemporânea. Cresce 0 tom de defesa da interdisciplinaridade entre as esferas estéticas e sociopolíticas, debate que envolve artistas e não-artistas. A presente enquete coloca-se de fato "em obras": não pretende exaurir o assunto, mas, ao contrário, funcionar como fórum para a recepção de outras ideias (LAGNADO, 2002) ${ }^{190}$.

O crescente entusiasmo artístico por questões sociais e a utilização do espaço urbano para a efetivação de parte dessas ações implicou em pensar outras demarcações nas concepções e práticas tanto da produção artística em relação à vida social e política quanto em alterações nas noções do papel do artista e do público e, das funções das instituições de arte. Se a profusão de novos termos ou sua retomada ${ }^{191}$ repõem alguns aspectos já discutidos pelas práticas experimentais nas décadas de 1960 e 1970 ou mesmo em períodos anteriores, elas não podem ser tomadas como réplicas ou mera continuidade do período anterior, como foi em diversas ocasiões tratado pelo discurso artístico quando os debates ainda eram incipientes ${ }^{192}$. Vale lembrar que, no caso brasileiro e de outros países da

189 Os autores das respostas publicadas foram: Alexander Pilis, Sergio Sister, Danilo Santos de Miranda, Dora Longo Bahia, Arthur Omar, Arnaldo Antunes, Fabiana de Barros, Luiz Camillo Osorio, Jarbas Lopes, Carla Zaccagnini, Tadeu Chiarelli, Mônica Nador, Per Hüttner Ricardo Basbaum, Camila Rocha, Rogério Degaki, Betty Leirner, Marcelo Cidade, Signey Philocreon, Eduardo Verderame, Jurandy Valença, Marisa Flórido, Cleomar Rocha, Fábio Lima Freire, Marcelo Coelho, Raul Barreto, Carlito Carvalhosa, Mari Stocker, Sylvia Furegatti, Yvonne Trapp, Celso Fioravante, Marina Saleme.

190 Disponivel em: <http://www.revistatropico.com.br/tropico/html/textos/956,1.shl>. Acesso em: 02 mai. 2015.

191 Um exemplo dessas retomadas pode ser detectado no uso do termo "relacional" no final da década de 1990, empregado, especialmente, por Nicolas Bourriaud - em seu livro Estética Relacional (1998) - em sentido praticamente idêntico ao proposto por Hélio Oiticica - no texto Bases fundamentais para uma definição do Parangolé (1964) - e também utilizado por Lygia Clark, em 1976, ao criar o que denominou de Objeto Relacional. $\mathrm{O}$ autor francês declarou ignorar a contribuição de Oiticica quando realizou uma conferência na $27^{\mathrm{a}}$ Bienal Internacional de São Paulo, em 2006. Tal fato foi divulgado na época e mencionado em reportagem jornalística, em 2009, quando seus livros Estética Relacional e Pósprodução foram lançados no país. Ao não fornecer créditos à contribuição dos artistas brasileiros em sua tentativa de estabelecer um novo marco conceitual, Bourriaud incorreu em apropriações indevidas, que podem ir além do conceito e da funcionalidade, e revisar inclusive a questão da autoria no que tange a produção que é realizada no centro e na periferia. Sobre as afirmações acima, conferir: FIGUEIREDO, Luciano (Org.). Aspiro ao grande labirinto Rio de Janeiro: Rocco, 1986; CYPRIANO, Fabio. Bourriaud analisa artes plásticas sem temor nem preconceito. São Paulo: Folha de S. Paulo, 16 de maio de 2009. Disponivel em: <https://www1.folha.uol.com.br/fsp/ilustrad/fq1605200910.htm>. Acesso em: 16 jul. 2018.

192 Cabe sublinhar a indagação -provocativa e frágil - de Nicolas Bourriaud na introdução do livro Estética Relacional (2009): "A que se devem os mal-entendidos que cercam a arte dos anos 1990, senão a uma falha do discurso teórico?". Para ele, "[...] a crítica contenta-se em inventariar as preocupações do passado apenas para poder lamentar a ausência de respostas" e pergunta: "[...] Como entender essas produções aparentemente inapreensíveis, quer sejam processuais ou 
América Latina, por exemplo, muitas das incursões críticas e experimentais dos anos 1960-70 tiveram como foco a oposição aos cerceamentos de regimes ditatoriais, denunciando também repressões culturais e sociais. Os reclames no período mais recente foram mais difusos, envolvendo uma extensa gama de requisições, que procuravam desde tensionar a verticalidade do campo artístico até desenvolver, muitas vezes, ações extradisciplinares. Para Ricardo Rosas, diversamente de outros países, em que a arte conceitual ativista teve certa permanência - ainda que com matizes diversificadas - da década de 1960 até a atualidade, no caso brasileiro, "em algum ponto, as ações conceituais mais politicamente incisivas no Brasil não tiveram continuidade, nem formaram uma 'tradição'”193. Por outro ângulo, Agnaldo Farias (2006b), ao analisar a expansão dos coletivos na cena artística brasileira, "[...] que balizam suas ações por investidas contra ou simplesmente fora das instituições", associa o fenômeno, sobretudo (conforme já foi mencionado), ao que denomina de "[...] uma estratégia de sobrevivência da arte diante da política de espetacularização que no Brasil adquire dimensões cada vez maiores" (FARIAS, 2006b, p.241).

Os debates em torno dessa conjuntura de alterações no campo da arte contemporânea estavam em curso no Espírito Santo - por meio das ações dos coletivos - e, avançados nos grandes centros, no período em que foi realizado por intermédio da Casa Porto das Artes Plásticas, pertencente à SEMC/PMV, o $8^{\circ}$ Salão Bienal do Mar ondas, pontes e intervenções navegáveis, em Vitória (ES). A mostra, que ocorreu entre 20 de dezembro de 2008 até 05 de fevereiro de 2009, pode ser tomada como um momento expressivo na cidade de Vitória da tentativa de colocar em pauta, por meio de um evento de intervenção urbana promovido pelo poder público, discussões envolvendo arte e democracia, e seus correlatos, substituindo a noção de arte/objeto por projetos e ações. Entretanto, as alterações mais profícuas no evento, efetuadas na oitava edição, não foram súbitas, mas desdobramentos de indagações que colocavam em xeque, dentre outras questões, a ocupação de espaços alternativos pela arte, bem como, os formatos e as premiações nos eventos artísticos competitivos. Tais questionamentos, que conduziram a reconfiguração de um salão regional de arte contemporânea para um projeto de intervenção urbana, foram iniciados na edição anterior do evento, realizada no ano de

comportamentais - em todo caso, 'estilhaçadas' segundo padrões tradicionais - sem se abrigar na história da arte dos anos 1960?". BOURRIAUD, Nicolas. Estética Relacional (1998). Tradução de Denise Bottmann. São Paulo: Martins, 2009 , p.9 e 10.

193 Neste texto, Notas sobre o coletivismo artístico no Brasil, o autor recordou que entre as décadas de 1970 e 1980 , surgiram vários coletivos de arte no país, entre os quais, Viajou sem passaporte, 3Nós3 ou Tupi Não Dá, ressaltando, porém, que tais formações, retomadas em meados dos anos de 1990, não possuíam vínculo com esses predecessores. Sublinhando ainda que, a mesma afirmação poderia ser aplicada à produção política de artistas como Cildo Meirelles e Hélio Oiticica, ainda que importantes e inspiradoras como fatos históricos, explorações "que levassem tais intervenções além do ponto em que pararam não se deram, de forma que, em algum ponto, as ações conceituais mais politicamente incisivas no Brasil não tiveram continuidade, nem formaram uma 'tradição'”. ROSAS, Ricardo. Notas sobre o coletivismo artístico no Brasil. Revista Trópico. Disponível em: <http://p.php.uol.com.br/tropico/html/textos/2578,1.shl>. Acesso em: 07 out. 2017. 
2006, e podem ser tomados como reverberações de questões mais amplas presentes nos debates do universo artístico a partir da década de 1990 impulsionadas por ideais "democráticos".

\subsection{FORMATOS E FRONTEIRAS}

O $7^{0}$ Salão do Mar foi um desdobramento de um salão anual tradicional de arte contemporânea que teve início em 1999 e que manteve sua formatação praticamente inalterada até sua sexta edição, realizada em 2004. A partir da sétima edição (2006) alterações mais efetivas foram efetuadas em seu perfil. Dentre elas, a abolição da divisão hierárquica da premiação, a substituição do envio da obra pela entrega do projeto ${ }^{194}$, a inclusão de todos os campos das artes visuais nas inscrições, a criação do Prêmio de Participação, e a conversão do âmbito e periodização da mostra de regional e anual para nacional e bienal. A nomenclatura do evento acompanhou essas remodelações: intitulado de 1999 até 2004 de Salão Capixaba do Mar, foi designado em 2006 de Salão do Mar e, em 2008, de Salão Bienal do Mar.

Ao longo de seu período inicial (1999-2004), além da manutenção da sua nomenclatura como Salão Capixaba do Mar, que restringia a participação no evento aos artistas residentes nos estados do Espírito Santo e Minas Gerais, áreas sob a jurisdição da Capitania dos Portos do Espírito Santo ${ }^{195}$, as inscrições eram limitadas às categorias de desenho, pintura, gravura, tridimensional, infoarte e instalação. Os prêmios eram aquisitivos e obedeciam a uma divisão hierárquica que acompanhava 0 valor recebido pelo artista vencedor: o primeiro lugar recebia o Grande Prêmio, seguido pelo segundo e terceiro prêmios ${ }^{196}$. O prêmio de Júri Popular, também aquisitivo, - era destinado ao artista cuja obra recebesse maior número de votos dos visitantes durante o período de funcionamento do Salão - foi mantido da segunda edição (2000) até a sétima edição (2006). Apesar de facultativo e não pecuniário,

\footnotetext{
194 Até a edição de 2004 as obras deveriam ser entregues no ato da inscrição no processo seletivo. No ano seguinte, incluiu-se a possibilidade de envio do projeto.

195 O Salão Capixaba do Mar é produto de uma história que tem início em setembro de 1999 com o empréstimo da antiga sede da Capitania dos Portos para a Prefeitura com o objetivo de realizar a exposição "Visão da Minha Vitória" em comemoração ao aniversário da cidade. Após o empréstimo do prédio, a parceria foi se consolidando e, em fevereiro do ano seguinte foi assinado um acordo em regime de comodato entre a Capitania dos Portos e a Prefeitura. Nessa fase de consolidação e estreitamento de laços, a Capitania dos Portos é sempre referenciada direta ou indiretamente, informal ou oficialmente. Além de o seu nome constar na logomarca da nova instituição - abaixo do nome Casa Porto das Artes Plásticas, escrito em itálico encontra-se "Antiga Capitania dos Portos". No texto da lei de criação, o artigo segundo diz que a "Casa Porto tem por objeto promover e sediar eventos relacionados às artes plásticas, fomentando o desenvolvimento cultural e desenvolvendo a mentalidade marítima na comunidade". A Casa Porto das Artes e, por conseguinte o Salão Capixaba do Mar nasceu impregnado do universo da Capitania dos Portos.

196 Os valores dos prêmios eram os seguintes. Da primeira (1999) até a quinta edição (2003), o primeiro Grande Prêmio era de $R \$ 4.000,00$, o segundo premiado recebia $R \$ 3.000,00$, enquanto o valor destinado ao terceiro era de $\mathrm{R} \$ 2.000,00$. 0 agraciado com o prêmio Júri Popular, também de caráter aquisitivo, recebia $R \$ 1.000,00$. Na sexta edição (2004), os valores destinados aos três premiados aumentaram, respectivamente, para $R \$ 5.000,00, R \$ 4.000,00$ e $\mathrm{R} \$ 3.000,00$, enquanto o Prêmio Júri Popular passou a ser de $\mathrm{R} \$ 1.500,00$.
} 
segundo o regulamento, menções honrosas foram distribuídas da primeira até a sexta edição - quase sempre em número de três e acompanhadas por termos mais ou menos pomposos ${ }^{197}$ - entre os artistas participantes. O regulamento da sétima edição (2006) manteve o dispositivo, porém, ele não foi utilizado.

A tentativa de formatar o evento capixaba em moldes mais contemporâneos é semelhante àquelas adotadas por iniciativas congêneres do período no Brasil, permitindo, grosso modo, a formação ou ampliação dos acervos locais - com custo relativamente baixo - a dispersão da produção artística realizada distante dos polos culturais brasileiros mais tradicionais (Rio de Janeiro e São Paulo) para além de suas fronteiras, e incentivo à produção emergente.

Apesar de considerados anacrônicos, salões de arte promovidos, sobretudo por secretarias municipais e estaduais de cultura, foram criados ou ampliados durante a década de 1990, preenchendo o vácuo deixado após a crise mais intensa das instituições culturais ocorridas no governo de Fernando Collor (1990-1992) com a extinção, dentre outros órgãos, da FUNARTE198 e, posteriormente, com o fim do Salão Nacional de Artes, em 1996. Indagações como "Para que servem os salões?" exemplificam simultaneamente o questionamento do modelo e sua importância no Brasil, a tal ponto que, no final de 2004, essa pergunta inaugurou a plataforma de fórum do site Canal Contemporâneo ${ }^{199}$. Naquele momento, discutir o funcionamento dos salões significava, conforme consta naquele endereço na web, debater "sobre o sistema de arte: sobre o que está dentro, fora e envolta dele" (CANAL CONTEMPORÂNEO, 2004)200. Essa mesma indagação serviu de mote para uma discussão pública realizada em abril de 2006, na Casa Porto das Artes Plásticas, alguns dias antes da abertura do $7^{\circ}$ Salão do Mar. Sugerida, por Waldir Barreto, que integrou a mesa redonda, a pergunta é análoga àquela que intitulou um texto anterior de sua autoria, na apresentação do Salão Nacional de Arte de Goiás - $2^{\circ}$

\footnotetext{
197 Somente para exemplificar, na primeira edição (1999) foram atribuídas três menções honrosas que eram conferidas pelos membros do Júri de Seleção e Premiação. No ano seguinte, foi incluída a Grande Menção Honrosa Capitania dos Portos do Espírito Santo (que incluía entre os jurados um membro da Capitania dos Portos do Espírito Santo), mantida a até a sexta edição (2004). Na quinta edição (2003) foi acrescentada a Menção Honrosa Especial - Troféu Navegante, além de terem sido atribuídas outras menções honrosas a quatro outras obras, designadas de apenas como Menção Honrosa.

198 Lei $n^{0}$ 8.029, de 12 de abril de 1990, extingue a Fundação Nacional de Artes - Funarte. Ver: http://www.funarte.gov.br/acessoainformacao/institucional/

199 No texto que consta no site do Canal Contemporâneo, é informado que: "A plataforma de fórum do Canal Contemporâneo, que estamos inaugurando com o trabalho 'Para que servem os salões?', participa da exposição 'Tudo aquilo que escapa' - com curadoria de Cristiana Tejo, que integra o $46^{\circ}$ Salão de Artes Plásticas de Pernambuco - nos permite avançar ainda mais na experiência de nossa comunidade digital." Disponível em: $<$ http://www.canalcontemporaneo.art.br/enformes.php?codigo=637>. Acesso em: 29 dez. 2014.

200 Disponivel em: <http://www.canalcontemporaneo.art.br/enformes.php?codigo=637>. Acesso em: 29 dez. 2014.
} 
Prêmio Flamboyant, realizado em 2002201. A discussão, que fazia parte da Jornada de Encontros com a Arte Moderna e Contemporânea, realizada em conjunto com o Centro de Artes da Universidade Federal do Espírito Santo (UFES) 202 , colocava em foco a pertinência do modelo dos salões de arte naquele momento e, por extensão, do próprio evento que a SEMC/PMV realizava desde 1999. A questão principal foi desdobrada em outras que questionavam a relevância e a necessidade de atualização do seu formato e as alternativas possíveis de premiação de projetos que contemplariam as alterações em curso no campo artístico. Incluir novos formatos de premiação com programas de bolsas, por exemplo, ainda eram iniciativas esparsas no Brasil, mas que já indicavam um deslocamento na noção de premiar a partir da obra para um investimento no processo de trabalho do artista203.

O já mencionado interesse institucional em expandir e nacionalizar os salões de arte fora do eixo Rio-São Paulo - com valores expressivos destinados às premiações ${ }^{204}$ e a inclusão de prólabores ${ }^{205}$, presentes, por exemplo, no Salão da Bahia e no Salão Nacional de Arte de Goiás (Prêmio Flamboyant) - pode ser analisado como uma mescla que urdia, por um lado, daquela premissa herdada do modernismo de que as artes - principalmente as artes plásticas - tinham por função criar uma imagem do nacional, uma mitologia do ser brasileiro que foi implementada por várias políticas nas décadas de 1930 e $1940^{206}$. Essa grande mitologia incluía subdivisões regionais que procuravam

201 Ressalta-se que Waldir Barreto, foi responsável pela concepção e consultoria do Salão Nacional de Arte de Goiás - $2^{\circ}$ Prêmio Flamboyant. "Salões de arte... pra que?" foi o título do seu texto. Ver: CATALÓGO DO SALÃO NACIONAL DE ARTE DE GOIÁS - $2^{\circ}$ Prêmio Flamboyant. Goiânia: Flamboyant Shopping Center. 19-06-2002 a 28-07-2002.

202 Foi realizada uma mesa redonda com a participação de professores da UFES (Waldir Barreto, Orlando da Rosa Farya, José Cirillo e David Protti) e, do membro da Comissão de Premiação do Salão (Agnaldo Farias), mediada pela Coordenadora da Casa Porto das Artes Plásticas (Samira Margotto). Após as apresentações o debate foi aberto para 0 público.

203 O Bolsa Pampulha, iniciado em 2003, como premiação do Salão Nacional de Arte de Belo Horizonte, serve para exemplificar a afirmação acima. Cabe sublinhar que o programa Bolsa Pampulha é conduzido pela Prefeitura de Belo Horizonte, por meio da Fundação Municipal de Cultura. Em 2016 foi realizada sua $6^{a}$ edição com curadoria de Cauê Alves, na qual, foram selecionados dez participantes que residiram por cinco meses em Belo Horizonte, com acompanhamento de Luisa Alves, Mabe Bethônico e Moacir dos Anjos. 0 resultado da produção desenvolvida foi apresentado na exposição Bolsa Pampulha 2016, no Museu de Arte da Pampulha.

204 O Salão da Bahia, por exemplo, desde sua terceira edição, em 1996, aumentou significativamente a quantidade e o valor dos prêmios. Se na primeira edição, "o Salão ofereceu seis prêmios aquisitivos no valor de cinco mil reais [...], na terceira edição dobrou para 10 mil reais, e na quinta subiu para 15 mil." A inserção do pró-labore teve início na quinta edição (1998). Ver: FERREIRA, Paula Scamparini. Legitimação e mediação da arte: projeções no contemporâneo. 2006. Dissertação (Mestrado) - Universidade Federal do Rio de Janeiro, 2006, p.84.

205 Ressalta-se que a inclusão do pró-labore ou prêmio de participação, facilitava financeiramente aos artistas de distintas regiões a participação nesses eventos.

206 O historiador Thomas Skidmore destacou que na década de 1930, especialmente a partir de 1937, o governo de Getúlio Vargas empenhou-se em consolidar o poder federal apelando para o nacionalismo e minando os regionalismos. Para tanto, além dos aspectos administrativos, investiu também naqueles de ordem simbólica, depois do golpe de 1937, Vargas "adotou uma tática mais direta", cujo exemplo mais representativo ocorreu quando "[...] em fins de novembro de 1937, o ditador realizou uma cerimônia pública, na qual queimou as tradicionais bandeiras dos Estados". No plano simbólico, houve resistências à política de Vargas, em várias regiões ou Estados brasileiros ocorreram tentativas de destacar peculiaridades regionais. SKIDMORE, Thomas. Brasil: de Getúlio Vargas a Castelo Branco (1930-1964). Rio de Janeiro: Editora Saga, 1969, p.91. 
demarcar, dentro desse "ser brasileiro", quais eram as características locais de cada Estado207. № entanto, por outro lado, essa regionalização pode ser tomada como iniciativas preliminares e possíveis naquele momento da inserção de cidades de menor porte no discurso corrente desse período que clamava para a importância da cultura e das artes no contexto da globalização da economia, projetando e distinguindo cidades ou regiões no mundo competitivo e globalizado. Sem perspectivas reais de alcançar projeção internacional, valia também a possibilidade de ganhar visibilidade dentro do próprio território nacional. Nesse sentido, Heitor dos Reis, diretor do Museu de Arte Moderna da Bahia (MAM/BA), afirmou em 2004 sobre o 110 Salão da Bahia que, considerando a qualidade do conteúdo e a pluralidade estética "[...] deste vitorioso projeto, a Bahia tem participado intensamente do processo de renovação, da criação e do pensamento em arte no Brasil" (REIS, 2004, s/p) ${ }^{208}$. A disputa pelo ranking nacional constituía o campo do possível das cidades e eventos na periferia mundial.

Nos discursos dos atores do universo institucionalizado da arte, a difusão de que o mapa artístico nacional estava sendo redesenhado foi, em diversas ocasiões, evocada. Exemplo disso, é a fala atribuída a Luiz Camillo Osório, em texto de Juliana Monachesi (2003) que, ao fazer um balanço da participação dos Rejeitados no Salão da Bahia de 2002, afirmou "que o interesse maior desse episódio foi a circulação de ideias do Amapá a Porto Alegre, uma oportunidade de 'mostrar o quanto o mapa artístico brasileiro é amplo e multirregional" (MONACHESI, 2003)209.

Para demonstrar essa descentralização, catálogos de diversos salões desse período são ilustrados com tabelas estatísticas ${ }^{210}$ que informam - questão, muitas vezes, reforçada nos textos de apresentação ou divulgação desses eventos ${ }^{211}$ - a origem dos inscritos e premiados. Artistas das

207 Desde o século XIX, portanto, o Rio de Janeiro é nossa cidade-natureza, cartão postal desta brasilidade mestiça na qual se unem, em harmonia, a natureza e a civilização; São Paulo, a locomotiva modernista, veio a ser a capital do progresso deste país do futuro; Minas Gerais e os Estados do nordeste também fixaram, via modernismo, micropolíticas identitárias, cada qual em busca de sua efígie. Para o Espírito Santo, tão próximo ao Rio de Janeiro, sobraram heróis ligados a outras localidades, como o Araribóia, de Niterói, ou o Anchieta, já tão paulista. A cidade-natureza Rio de Janeiro em miniatura, cidade presépio, com sua paisagem marinha, serviu, então, para dar feição à Vitória que se modernizava nos meados do século XX. Não à toa, pinturas de paisagem, da "natureza capixaba" foram as mais buscadas pelo mecenato público, entre as décadas de 1930 até 1960. Uma análise do predomínio da pintura de paisagem nos principais acervos governamentais do Espírito Santo, durante o período em questão, pode ser consultada no seguinte livro: MARGOTTO, Samira. Cousas Nossas: pintura de paisagem no Espírito Santo: 1930-1960. Vitória: EDUFES, 2004.

208 CATALOGO DO $11^{\circ}$ SALÃO DA BAHIA. Salvador: Museu de Arte Moderna da Bahia. 04-12-2004 a 23-01-2005.

209 Outro exemplo consta no texto Chat Mostra Rio Arte Contemporânea, no qual, Lisette Lagnado defendeu que o "[...] grande ganho, nos últimos anos, é que o eixo Rio-São Paulo não é mais hegemônico" (LAGNADO, 2002, p.309). Ver, respectivamente: MONACHESI, Juliana. Artes muito contemporâneas. Salões e crítica institucional. Disponível em: <http://www.revistatropico.com.br/tropico/html/textos/1595,1.shl>. Acesso em: 25 mar. 2015. LAGNADO, Lisette. Chat Mostra Rio Arte Contemporânea (2002). In: FERREIRA, Glória. Crítica de arte no Brasil: temáticas contemporâneas. Rio de Janeiro: Funarte, 2006.

210 Ver, por exemplo, catálogos dos Salões da Bahia, do Salão Nacional de Arte de Goiás e do $7^{0}$ Salão do Mar, em Vitória.

211 Corroborando com os exemplos mencionados, no site da Bienal de São Paulo, informando sobre a $25^{\mathrm{a}}$ edição "Iconografias urbanas", o texto destaca duas questões. A primeira é que a edição de 2002 "tornou-se famosa pela presença 
regiões Norte, Centro-Oeste e de Estados economicamente menos expressivos do Nordeste, ainda que figurem entre os inscritos, poucas vezes aparecem entre os selecionados. Em termos quantitativos, essas inscrições eram irrisórias, predominando, nos Salões que ofereciam premiações com valores mais expressivos, artistas provenientes de São Paulo e do Rio de Janeiro, em números que muitas vezes ultrapassava os dos inscritos do próprio Estado promotor do evento ${ }^{212}$. Dificilmente, entretanto, não eram incluídos entre os premiados artistas locais. No Salão da Bahia, por exemplo, entre 1994 até 2005, apenas no ano de 2004 não constou nenhum artista baiano entre os premiados (FERREIRA, 2006, p.183) e no $14^{\circ}$ Salão da Bahia (2007) foi incluído junto aos seis prêmios de aquisição, três prêmios de residência artística, exclusivos para artistas baianos residentes no Estado213.

Com algumas distinções, essas questões também aparecem com a nacionalização do $7^{\circ}$ Salão do Mar (2006). Neste, dos 410 inscritos de 19 Estados brasileiros, a quantidade mais expressiva foi de São Paulo (117), seguido pelo Espírito Santo (76), Rio de Janeiro (63), Paraná (41) e Minas Gerais (31). Foram selecionados 21427 participantes, dos quais, 9 eram de São Paulo, 6 do Espírito Santo, 5 do Rio de Janeiro, 2 de Minas Gerais, 2 de Pernambuco, e Goiás, Rio Grande do Sul e Santa Catarina com apenas 1 participante cada. A concessão dos prêmios ${ }^{215}$, entretanto, não seguiu a lógica protecionista corrente em iniciativas semelhantes, como exemplificado no Salão da Bahia: os três prêmios aquisitivos foram atribuídos a artistas de outros Estados brasileiros ${ }^{216}$. Sem oferecer valores expressivos para os premiados ${ }^{217}$, como o Salão da Bahia, por exemplo, e com número reduzido de

numerosa de artistas brasileiros fora do eixo São Paulo/Rio de Janeiro" e, em seguida, sublinha que "A nomeação do primeiro curador estrangeiro, 0 alemão Alfons Hug, causou polêmica em alguns setores, que viam na escolha uma espécie de dominação sobre a soberania artística brasileira". Disponivel em: <http://www.30xbienal.org.br/single/114>. Acesso em: 20 out. 2017.

212 No Salão Nacional de Arte de Goiás $-2^{\circ}$ Prêmio Flamboyant (2002), que oferecia dois mil reais de pró-labore para os selecionados e contemplava os cinco premidos com dez mil reais cada, 331 inscritos eram de São Paulo, seguido por 324 do Rio de Janeiro e 251 de Goiás. Os estados do Piauí e Amazonas, por exemplo, tiveram apenas 1 inscrito de cada; do Tocantins e Amapá somente 3 inscrições. No $9^{\circ}$ Salão da Bahia (2002), o pró-labore era de mil reais e os seis prêmios aquisitivos eram de 15 mil reais cada. Neste, 442 dos inscritos eram de São Paulo, 268 do Rio de Janeiro e 226 da Bahia. Novamente, poucos foram os inscritos dos estados da região Norte e Centro-Oeste, o Acre e o Amapá, por exemplo, tiveram apenas 1 inscrito de cada.

213 Disponivel em: <http://www.canalcontemporaneo.art.br/saloesepremios/archives/2007_09.html>. Acesso em: 20 out. 2017.

$214 \quad$ A Comissão de Seleção foi composta por Dária Jaremtchuk, Fernando Cocchiarale, José Cirillo, Juliana Morgado e Maria Helena Lindenberg.

215 Os membros da Comissão de Premiação foram: Agnaldo Farias, José Cirillo, Juliana Morgado, Maria Helena Lindenberg e Samira Margotto.

216 Os premiados pela Comissão foram: o pernambucano Lourival Cuquinha Batista (Varal) e as paulistas Patrícia Osses (Mar de Gropius) e a Camila Sposati (Fumaça de sinalizador). Destaca-se que o Prêmio Júri Popular foi atribuído à carioca Isadora Bonder (Caiximiti).

$217 \quad 07^{\circ}$ Salão do Mar conferiu três prêmios, cada um no valor de $\mathrm{R} \$ 6.000,00$, e um Prêmio de Júri Popular, no valor de $R \$ 1.200,00$. Para efeito de comparação, no $14^{\circ}$ Salão da Bahia (2007) foram concedidos seis prêmios no valor de $\mathrm{R} \$ 15.000,00$ cada, mais 3 prêmios de residência artística (duas internacionais e uma nacional) exclusivo para artistas baianos residentes no Estado. Sobre 0 regulamento do $14^{\circ}$ Salão da Bahia, ver: http://www.canalcontemporaneo.art.br/saloesepremios/archives/001421.html. 
prêmios, a nacionalização do Salão do Mar exigia que o mesmo obtivesse credibilidade junto aos participantes de outros locais, já que os Salões, como qualquer outro processo seletivo, eram frequentemente acusados de parcialidade e protecionismo pelos excluídos.

A premiação era apenas um dos atrativos que interessava a um artista em fase de consolidação da sua carreira. O reconhecimento por curadores com trânsito nos grandes centros representava fator relevante para os portfólios dos competidores. Mais importante ainda, a constituição de uma banca não local incutia isenção nas escolhas, convertendo-se em importante fator, principalmente aos participantes locais. Assim, a divulgação do edital era acompanhada do nome e da procedência dos responsáveis pela seleção, nomes que, quase sempre, já estavam consolidados no circuito nacional das artes. No caso do Salão do Mar, a inclusão de membros de outros Estados da Federação nas Comissões de Seleção e Premiação era prática comum mesmo durante o período em que a participação era restrita aos artistas do Espírito Santo e Minas Gerais. Esse dispositivo só não ocorreu na quinta edição (2003), na qual, a Comissão de Seleção e Premiação foi composta exclusivamente por profissionais atuantes no Espírito Santo 218.

Indicar a procedência dos participantes e responsáveis pela seleção e premiação não é apenas uma informação corriqueira. Ela é tributária da noção em voga que as distinções entre centro e periferia estavam se dissipando. Internacionalmente, nas bienais (trienais e quinquenais) a nacionalidade dos participantes é também destacada. Chin-Tao Wu (2012) ao mapear as alterações no perfil geográfico dos participantes de nove edições da Documenta de Kassel (1968-2007), concluiu que eles "passaram de um eurocentrismo quase explícito para englobar o mundo além dos países que compõem a OTAN" (2012, p.111). Em face disso, a autora indagou:

Os tão discutidos colapsos do centro e dissolução da periferia seriam mesmo tão irrefutáveis como algumas pessoas querem nos fazer acreditar? Terá o mundo das artes se tornado tão poroso, aberto a todos os artistas, independente de suas origens [...]? (WU, 2012, p.111) ${ }^{219}$.

Essas perguntas impulsionaram Chin-Tao Wu a analisar o crescente destaque concedido ao aspecto da nacionalidade na Documenta de Kassel. Para ela, a dissonância entre falar de nacionalidade em um período que preconiza a globalização, hibridização e transnacionalização nos mercados globais é indissociável da inclusão da noção de internacionalização presente nesses eventos (2012, p.110), ressaltando ainda que artistas de países remotos são apresentados com destaque em eventos como a Documenta de Kassel ou a Bienal de Veneza, como provas de que "a distinção entre

\footnotetext{
218 Em 2003, os membros da Comissão foram: Maria Helena Lindenberg, José Aparecido Cirillo e Samira Margotto.

219 WU, Chin-Tao. Bienais sem fronteiras?. Tradução de Bruno Costa. Novos estudos/ CEBRAP, São Paulo, n. 94, p. 109-116, Nov. 2012. Disponível em: <http://www.scielo.br/pdf/nec/n94/n94a05.pdf>. Acesso em: 11 out. 2017.
} 
centro e periferia já não existe" (2012, p.110). Entretanto, Wu concluiu que, ao mesmo tempo em que a procedência dos artistas participantes das nove edições da Documenta ficou mais heterogênea, ocorreu também um fluxo unidirecional desses artistas aos grandes centros da América do Norte e da Europa, "muito provavelmente em busca de melhores sistemas de apoio e infraestrutura" (2012, p.114). Esses dados induzem Chin-Tao Wu a concluir que, diversamente do que muitos defendem, a relação dos centros e da periferia não é uma questão do passado, como foi intensamente divulgado na Documenta $11(2002$, p.115)220:

[...] há algo altamente incongruente em tratar uma exposição como a Documenta 11, na qual quase $78 \%$ dos artistas representados vive atualmente na América do Norte ou Europa, como ilustração da "total emergência da margem (WU, 2012, p.115).

Tanto no caso das bienais internacionais quanto no desses salões regionais, sabe-se que foi mais retórica que efetiva a ideia de inclusão de artistas de lugares remotos e a dissolução de demarcações entre centro e periferia, podendo ser tomados como desdobramentos da noção de democracia (e questões correlatas, guiadas, no caso desses eventos internacionais de grande porte, pelas ideias anticolonialistas). Esta constatação da diminuta efetividade do discurso, entretanto, não descarta que alterações ocorreram no sentido de integrar alguns excluídos. Porém, o que deve ser sublinhado é que o discurso legitimador continuou a ser irradiado dos centros hegemônicos. Como enfatizou Gerardo Mosquera (2003)221 “ser 'internacional' ou 'contemporâneo' na arte é apenas o eco de ser exibido em espaços de elite de Nova York ou Dusseldorf' (2003, p.82). Para Mosquera, termos como "linguagem universal" e "linguagem artística contemporânea", podem ser pensados como limitando o que o mainstream nomeia e distribui como produto cultural (2003, p.82). Assim, a noção de apagar fronteiras têm como obstáculo os cânones de codificação vigentes na arte da atualidade, dentro de uma linguagem comum do modernismo que foi forjada em torno dos anos de 1930, congregando distintas rupturas realizadas pelas vanguardas históricas, seguida por reorientações provenientes da pop, do conceitualismo, da minimal etc. e, que nos anos de 1990 foi instituída em "um tipo de 'linguagem internacional pós-moderna' da arte, que prevalece na chamada cena internacional, ainda que sua chancela enquanto código dominante negue" (MOSQUERA, 2003, p.82). Para o autor, essas construções abstratas que classificam a arte contemporânea são muito mais tributárias da consciência moderna do que dos processos de globalização (2003, p.80), pois, elas:

220 Conforme, sublinhou a autora: "Embora a exposição 'Magiciens de la Terre', realizada em 1989 no Centro George Pompidou (Paris), seja geralmente considerada a primeira mostra de fato internacional e um marco para a tendência que se seguiria na década seguinte, norte-americanos e europeus são ainda predominantes nas edições da Documenta de 1992 e 1997. A mudança real aconteceu na Documenta 11, de 2002, com Okwui Enwezor, quando a proporção de artistas ocidentais caiu para os respeitáveis $60 \%$. A proporção permaneceu semelhante em 2007." Wu, Chin-Tao. Bienais sem fronteiras?. Tradução de Bruno Costa. Novos estudos/CEBRAP, São Paulo, n. 94, p.109-116, Nov. 2012, p.112.

221 MOSQUERA, Gerardo. Linguagem internacional?. Tradução de Marcelo Campos. Arte \& Ensaios. Número 10. Rio de Janeiro: PPGAV/EBA/UFRJ, 2003, p.80-83. 
Contém uma simplificação totalizadora e um exclusivismo que hierarquiza uma espécie de comunicador universal e contemporâneo acima das diferenças. Isso implica um caráter axiológico: o grau de universalidade e contemporaneidade será decisivo para se julgar 0 valor da obra de arte. Os termos 'internacional' e 'contemporâneo' estão, em si mesmos, carregados de implicações do discurso moderno (MOSQUERA, 2003, p.80).

A diversidade almejada no período, resultante da pressão do multiculturalismo e da abertura pós-moderna, aliada à linguagem comum da arte contemporânea, apresenta-se de forma diversa do centro para a periferia e da periferia para o centro. Em relação à primeira, Mosquera, afirmou que, de modo geral, a pluralidade respondeu mais a uma "tolerância paternalista e politicamente correta" do que uma "nova consciência". Para o autor, prevalece nos circuitos do poder simbólico, "além da retórica, a intolerância cortês" (2003, p.83). Por outro lado, os códigos vigentes na arte, "em virtude de sua aura legitimadora, são imitados ou apropriados pelas periferias" (2003, p.82). Esta codificação, é possível acrescentar, foi naturalizada ao longo dos séculos e, recorrendo à análise emblemática de Carlo Ginzburg, tornou-se inevitável: "da cultura do próprio tempo e da própria classe não se sai a não ser para entrar no delírio e na ausência de comunicação" (GINZBURG, 2006, p.20)222.

Sabe-se que a noção de inclusão, presente tanto na relação dos centros com as periferias quanto das periferias com as subperiferias, fez parte da retórica disseminada a partir da década de 1990. O que importa sublinhar não é tanto a efetividade dessas estratégias, mas o impulso que as guiava: a tentativa de ampliar limites, de ir além das demarcações historicamente assentadas entre centro e periferia e, por extensão de outras questões que procuravam minar hierarquias de poder, como 0 interesse por questões sociais, particularismos de gênero, raça, sexualidade etc.. 0 caráter retórico fica evidente quando se examina o que é enfatizado ou omitido. Um exemplo sintomático pode ser aferido nas apresentações de algumas edições da Documenta de Kassel retiradas do site da instituição. Da mesma maneira que é ressaltada a diversidade da procedência dos artistas é também sublinhada a inclusão feminina e de um não europeu na direção artística nas edições de 1997 e 2002. Em ambos os casos, a informação inicial não recai sobre o projeto curatorial. Em relação à edição de 1997 é afirmado: "A última Documenta do século XX foi a primeira dirigida por uma mulher, a curadora francesa Catherine David. Como previsível, ela foi esperada em Kassel com ceticismo"223. O segundo caso, em 2002, é igualmente sintomático: "Okwui Enwezor, nativo da Nigéria, foi o primeiro diretor de arte não europeu da Documenta", a informação posterior exalta o caráter verdadeiramente global da

222 GINZBURG, Carlo. 0 queijo e os vermes: o cotidiano e as ideias de um moleiro perseguido pela Inquisição. Tradução de Maria Betânia Amoroso. São Paulo: Companhia das Letras, 2006.

223 Ressalta-se que, as informações iniciais induzem o leitor a pensar que o ceticismo mencionado é em relação ao fato da Documenta $X$ estar sendo dirigida por uma mulher, no entanto, a referência seguinte recai sobre as questões abordadas no projeto curatorial. Disponível em: <https://www.documenta.de/en/retrospective/documenta_x>. Acesso em: 12 out. 2017. 
exibição224. Diversamente, a edição sequente do evento, em 2007, desta vez curada por Ruth Noack e com Roger M. Buergel assinando a direção artística, a nacionalidade deles não é mencionada: ambos são alemães. A ênfase no parágrafo inicial recai no fato de terem burlado os estatutos do evento que permitia apenas uma única pessoa na direção da mostra225. Em 2012, a direção artística coube à norteamericana Carolyn Cristov-Bakargiev, sua nacionalidade não é referida, no entanto, exalta-se que: "Pela segunda vez em sua história, a Documenta foi dirigida por uma mulher"226. É possível supor que a natureza da apresentação da instituição para o grande público, por meio do endereço eletrônico, sublinhando tanto o gênero feminino quanto a origem africana que se constituem como excentricidades à altura da partilha por dois curadores na direção da mostra, revela, pelo menos neste quesito, uma faceta ordinária pouco condizente com as elevadas pretensões intelectuais do evento. Na contramão dessa inclusão retórica, típica desse período, a confecção das tabelas estatísticas do $7^{0}$ Salão do Mar indicava a procedência dos artistas baseada no local de residência e não de nascimento227. Nesse sentido, tanto Roosivelt Pinheiro 228 - natural de Nhamundá, no estado do Amazonas - quanto Carla Zaccagnini - nascida em Buenos Aires, Argentina - foram registrados, respectivamente, como provenientes do Rio de Janeiro e São Paulo, em uma tentativa de evitar enaltecimentos em relação às origens. A informação, portanto, recaia sobre o contexto que atuavam e receberam suas formações na área.

Tanto as omissões quanto as tentativas de enxertar os excluídos são vinculadas e dependentes da forma que o discurso é estruturado e, consequentemente dos pressupostos que ele carrega. Mais do que as respostas, o que importa é quem faz e como são feitas as perguntas, pois serão elas que delinearão sua supervisão, seu controle. Assim, as concessões por gênero ou procedência, presentes nos grandes eventos internacionais e algumas das tentativas no Brasil, por meio dos salões, de ampliar o circuito artístico além dos centros hegemônicos tradicionais (às quais devem ser acrescentados os mapeamentos mais sistemáticos como o realizado, desde 1999 até 0 momento presente, pelo Projeto Rumos do Instituto Itaú Cultural), circunscreveram, sobretudo, inclusões que são convenientes. O porquê de sua conveniência nesse período é parte integrante da disseminação do termo "democracia" em esferas diversas. Tal questão deve ser problematizada, ainda

\footnotetext{
224 Disponível em: <https://www.documenta.de/en/retrospective/documenta11>. Acesso em: 12 out. 2017.

225 Disponível em: <https://www.documenta.de/en/retrospective/documenta_12>. Acesso em: 12 out. 2017.

226 Disponível em: <https://www.documenta.de/en/retrospective/documenta_13>. Acesso em: 12 out. 2017.

227 Cabe ressaltar que na ficha de inscrição do $7^{\circ}$ Salão do Mar era solicitado tanto o endereço do artista quanto 0 seu local de nascimento.

228 Os dados que embasam essas afirmações foram retirados do currículo Lattes de Roosivelt Pinheiro. Disponível em: <http://buscatextual.cnpq.br/buscatextual/visualizacv.do?id=K4269306P6>. Acesso em: 29 out. 2017.
} 
que não se discorde, uma vez mais, que inclusões reais ocorreram - mesmo que diminutas e filtradas pelos discursos produzidos e difundidos a partir dos grandes centros.

A afirmação que o mapa artístico nacional estava sendo "redesenhado" e a pergunta reiterada nesse período no Brasil "Para que servem os salões?" 229 em conjunto com iniciativas diversas de reformular os formatos desses certames encobriu questões mais salutares, entre as quais, o que significava para a produção de um artista, formar-se e pertencer a um circuito cultural afastado, dentro de um período que apregoava aquilo que Gerardo Mosquera designou como "linguagem internacional"? No campo da visualidade, é na articulação entre repertórios simbólicos da tradição artística ocidental, especialmente a partir do modernismo, com os provenientes de contextos geográficos e identitários distintos que é possível situar as tentativas de ressignificação das diversidades almejadas. Apontar apenas para as novas facilidades de acesso à informação, para a crítica aos localismos, para a universalidade da arte contemporânea, não dá conta dos inúmeros problemas de divulgação/dispersão cultural do polo para a periferia e vice-versa. De forma semelhante, sabe-se retórica paternalista e ineficaz qualquer investida de tutela ou proteção do artista local. São essas questões em aberto que emergiram durante a experiência de nacionalização de um salão regional e que serviram para problematizar, não apenas sua formatação, mas, sobretudo, as possibilidades de inserção de uma produção artística desenvolvida distante dos centros hegemônicos, em um país periférico que institui, também, suas periferias.

\subsection{SEDUZIR E AFERIR}

\footnotetext{
229 Outro exemplo, envolvendo as discussões em torno da pertinência dos salões de arte, ocorreu em 29 de novembro de 2003, na Pinacoteca do Estado de São Paulo. Com mediação de Lisette Lagnado e a participação de Adriano Pedrosa e Daniela Bousso, segundo consta no site da revista Trópico, a ideia do encontro consistiu "em pensar soluções de adequação do formato do salão para a realidade contemporânea. Quais são os motivos que continuam justificando sua existência? Que tipo de 'premiação' poderia contemplar o reconhecimento do valor de uma jovem carreira artística? Será que sua periodicidade deve ser anual ou bienal?". Disponível em: <http://www.revistatropico.com.br/tropico/html/textos/1770,1.shl>. Acesso em: 20 out. 2017.
} 


\title{
2.2.1. Ações e relações
}

\begin{abstract}
Eu sei que não existe absolutamente uma audiência para a escultura, assim como não há para a poesia e para o filme experimental. Existe, contudo uma grande audiência para produtos que propiciam as pessoas o que elas querem e supostamente precisam, mas não mais do que elas podem compreender. 0 marketing é baseado nesta premissa. [...]. Considerando que não existe audiência para a escultura e para a poesia, ninguém reivindica que elas resistam à manipulação externa (Richard Serra)230.
\end{abstract}

A importância conferida à noção numérica dos visitantes nos eventos artísticos - intensificada a partir da década de 1990 - é indissociável do debate sobre democracia no plano da arte. São também aspectos correlatos desse mesmo processo, a aproximação da arte com outras esferas da criação, o caráter de espetáculo e a expansão de ações educativas nas exposições. Seduzir e aferir são termos convergentes nas tentativas de ultrapassar o caráter mais restrito do público interessado por uma produção artística experimental, conforme pontuado por Richard Serra na epígrafe acima.

Em 28 de abril de 2006, uma multidão surpreendente para um evento competitivo de arte contemporânea em Vitória - destinado a exibir a produção de 27 artistas emergentes, dos quais, apenas 6 eram do Espírito Santo - compareceu na abertura do $7^{\circ}$ Salão do Mar231 (Fig. 09). É possível presumir, ou mesmo afirmar que, a parte mais considerável desse público não era formada pelos interessados nos rumos da arte contemporânea, especialmente por meio da produção de artistas com carreiras ainda não consolidadas. 0 mais provável é que essa leva diversificada de visitantes tenha sido atraída pelo espaço de realização da mostra, o maior dos cinco armazéns do Cais Comercial do Porto de Vitória: o Armazém 5, com uma área total de $3.110 \mathrm{~m}^{2}$ (MORAIS, 2014, p.108) da qual foi utilizada na mostra cerca de $1.096 \mathrm{~m}^{2232}$, acrescidos do espaço externo, área alfandegada de acesso ao Cais. Assim, quando as portas do Armazém 5 - situadas na Avenida Getúlio Vargas, via

230 SERRA, Richard. Writings Interviews. MIT Press, 1994, p. 143. In: FUREGATTI, Sylvia. Arte e meio urbano: elementos de formação da estética extramuros no Brasil. 2007. Tese (Doutorado) - FAU/USP, 2007, p.24.

231 Nesta edição o livro de assinaturas foi substituído por um contador eletrônico. Desta forma, apesar de considerar a diversidade da forma de registro (sabe-se que nem todos que visitam assinam os livros, assim como, muitos adentram 0 espaço sem passar pelas "catracas" ou funcionários podem ser registrados com público), cabe expor, os dados levantados em relação às edições anteriores: A primeira (1999) contou com 1.041 visitantes, a segunda (2000) teve 1.102, a terceira (2001) registrou 1.633, na quarta (2002) consta 821, na quinta (2003) o número foi de 535 e na sexta (2004) não foi localizado o registro do número de visitantes. Ressalta-se que os dados acima foram retirados do relatório realizado para $7^{\circ}$ Salão do Mar, com base nos documentos da instituição.

232 Não foram localizadas as plantas arquitetônicas do evento (eram duas, uma do espaço interno e outra do externo), entretanto, a menção à área, considerou que, posteriormente, a realização do Salão do Mar pela Secretaria Municipal de Cultura, outro órgão da Prefeitura (SEDEC) arrendou o espaço para a realização do projeto Estação Porto (MORAIS, 2014, p.146), voltado para a apresentação de shows de música e recepção dos turistas que chegavam de navio à cidade. Assim, a área mencionada é a que consta no segundo projeto da PMV. MORAIS, Lívia Santos de. Porto de Vitória: Armazéns do século XX patrimônio industrial e memória do trabalho. 2014. Dissertação (Mestrado em Artes) - Universidade Federal do Espírito Santo, 2014. 
de grande circulação no Centro de Vitória - foram destravadas, poucos dias antes da abertura do evento, 0 interesse por adentrar nesse espaço de grande importância simbólica no imaginário local foi aguçado. Sublinhando o cenário, o dia da abertura contou com parte daquela avenida interditada, uma iluminação mais intensa que a habitual sobre a fachada do prédio e dois dos imensos guindastes amarelos que, junto aos navios de grande porte e embarcações menores, complementavam as referências à paisagem da capital do Espírito Santo, marítima por excelência.

Figura 09 - Abertura do $7^{\circ}$ Salão do Mar

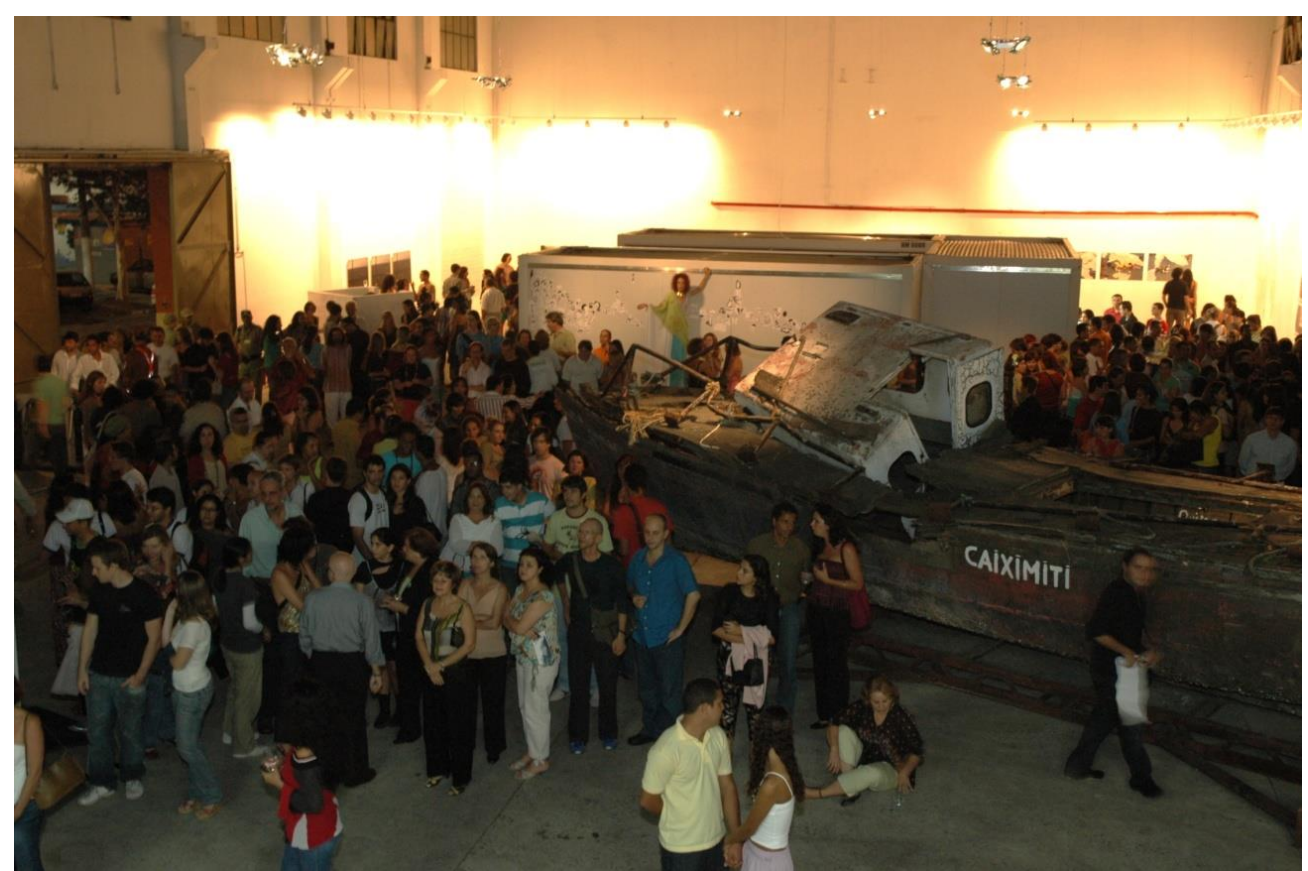

Fonte: Arquivo da autora. Foto: Marcos Salles (2006).

Desde a década de 1940, quando se instaurou "a noção de porto organizado", o Cais Comercial do Porto de Vitória foi isolado do público. Os armazéns "eram e ainda constituem um obstáculo entre o Porto [o mar] e a cidade" (MORAIS, 2014, p.100 e 101). Segundo Lívia Morais, as obras de modernização efetuadas nesse período - com a aquisição de guindastes e a movimentação operacional - que restringiram o acesso da população ao porto, foram justificadas tanto para garantir a proteção das pessoas ${ }^{233}$, quanto das cargas armazenadas, passíveis de furtos e danos. Assim, 0 reforço na segurança e a função dos "fiéis de armazém", zeladores das mercadorias que existem até hoje, são resquícios dessas alterações que criaram barreiras entre a população e o porto. Segundo

233 Conforme sublinhou a autora, com o crescimento das movimentações na área operacional passou a ser recomendado que não houvesse trânsito em baixo das cargas suspensas: "Havia riscos de rompimento de cabos de aços dos equipamentos de içar. Dessa forma, foi necessário o isolamento dessas áreas com a população, passando a ter restrições de acesso, permitido apenas aos trabalhadores portuários e tripulantes" (MORAIS, 2014, p.100). 
Morais, "a estrutura dos cinco armazéns contribuiu para o bloqueio à entrada de pedestres" e os portões de acesso ao porto passaram a ter vigilância ininterrupta (2014, p.100). Evidentemente, tanto os argumentos utilizados para o isolamento do porto, quanto a possibilidade de abertura para a população, por meio de um evento cultural, encobriam interesses e negociações de ordem política e econômica. Se no período anterior, segurança e proteção para a população serviram de pretexto, os substituídos contemporâneos utilizados giravam em torno da apologia dos benefícios culturais, da revitalização dos centros urbanos e as possibilidades de inserção de cidades periféricas nos fluxos globais de riqueza.

A tentativa de reestabelecer a relação porto-cidade, ainda que por um breve período, foi evocada no $7^{\circ}$ Salão do Mar. Se, os portões abertos constituíam o convite mais evidente à entrada, os transeuntes também eram atraídos por um inusitado varal de roupas que "o artista pernambucano Lourival Cuquinha Batista [...] estendeu desde a viga mestra do armazém até a fachada de um prédio situado do outro lado da avenida" (FARIAS, 2006d, p.17). Esta intervenção (Fig. 10), tão emblemática do evento, ligando a cidade ao espaço cedido para a exposição, é sugestiva da noção aventada em torno da tomada da esfera pública pelos agentes do campo artístico.

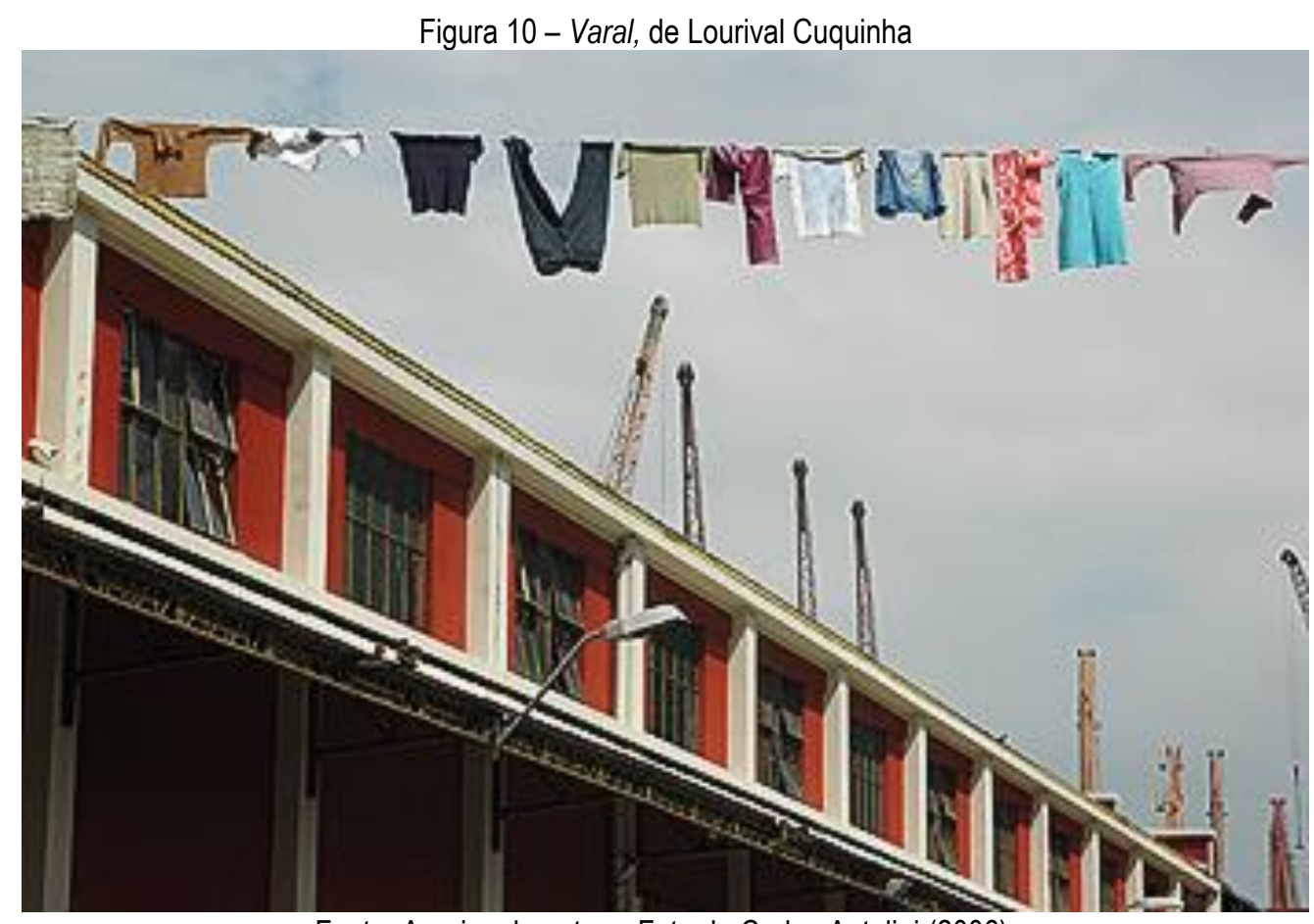

Fonte: Arquivo da autora. Foto de Carlos Antolini (2006).

Ainda que essa tomada seja apenas simbólica, ela não deixa de suscitar indagações sobre tensões sociais, mesmo quando se aproxima da ideia de espetáculo. No dia abertura do Salão do Mar, não foi apenas por meio das obras dos artistas selecionados que tais questões estiveram presentes: 
em parceria com outros segmentos criativos locais, performances com aparatos estetizantes foram incluídas no evento. Algumas delas abordaram de forma mais profícua elementos singulares do universo portuário, fazendo apropriações e discutindo exclusões. A política com propósitos, sobretudo econômicos, que reduziu o porto para a população a um elemento para ser contemplado mais do que vivenciado como outrora, foi matéria-prima para três trabalhos. A artista plástica e designer Vera Colodetti 234 , por exemplo, utilizou os guindastes, que na década de 1940 foram elementos que simultaneamente modernizaram e ajudaram a respaldar o fechamento do porto aos cidadãos comuns, na performance de sua autoria. Nesta, alguns jovens escalaram a estrutura metálica (Fig. 11) e um deles disparou um sinalizador de fumaça em um dos pontos mais altos do guindaste. Já as designers Stael Magesck e Gabi Lima destacaram a figura feminina e sua relação com o ambiente portuário, predominantemente masculino. A primeira fez circular pelo espaço uma gigantesca e imponente mulher sobre uma "perna de pau" - figura retirada da cultura circense - em que o tamanho avantajado camufla a fragilidade da base de apoio. Gabi Lima extraiu suas referências do universo da cultura pop, fazendo uma junção de imagens popularizadas das figuras femininas de cabarés com as das Pin-ups. A designer vestiu uma mulher jovem (de rosto com traços infantis), com um maiô estampado de onça e meias arrastão, rolos nos cabelos e maquiagem acentuada. Pendulando entre ambições de conquista e vestígios que reiteram imagens e lugares historicamente assentados, subjaz a rigidez atribuída nos modos possíveis de ser e aparecer, fronteiras que podem ser flexibilizadas, mas dificilmente rompidas. Qual o lugar destinado à mulher na sociedade, especialmente quando recortada a partir do universo masculino? Até que ponto a arte poderia ocupar o Porto?

\footnotetext{
$234 \quad$ Vera Colodetti, além de apresentar sua performance, circulou pelo evento com uma pomba branca sobre um dos seus ombros. Remetendo ao universo onírico do surrealismo, em uma releitura das imagens de animais que Elsa Schiaparelli em criações, muitas vezes partilhadas com Salvador Dali, introduzia nas suas peças.
} 


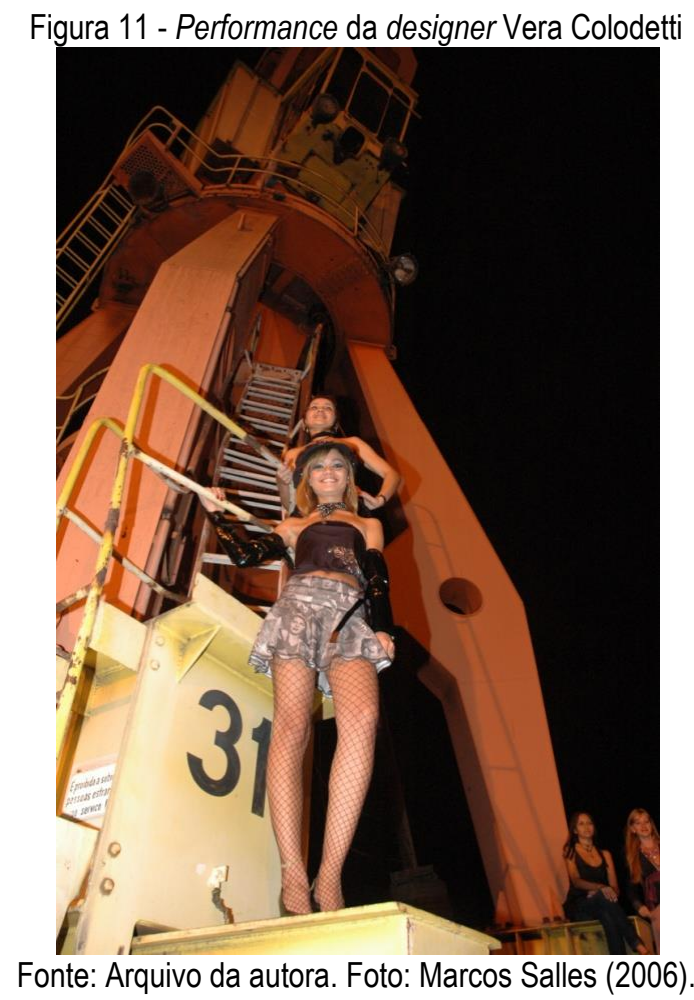

Figura 12 - Performance da designer Stael Magesck

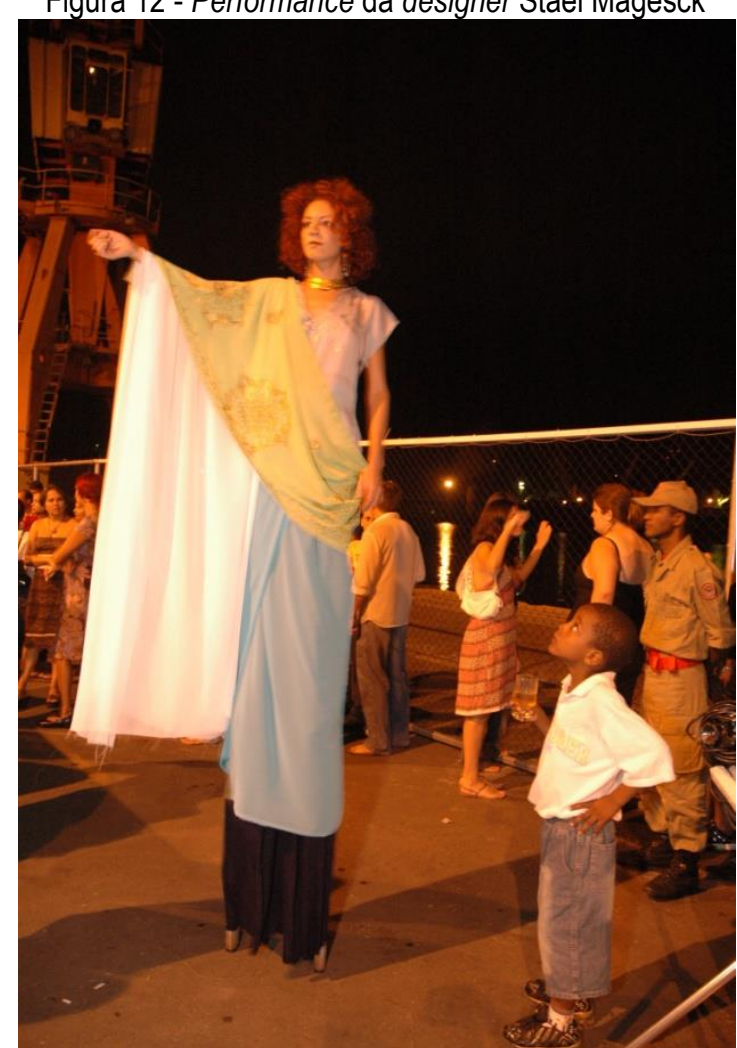

Fonte: Arquivo da autora. Foto: Marcos Salles (2006).

Tais indagações podem também ser estendidas à inserção dos trabalhos de designers nos eventos de arte contemporânea. No caso do $7^{\circ}$ Salão do Mar, este encontro não deixou de carregar resquícios do legado modernista. A apresentação da produção dos designers na abertura do evento, 
quando analisada em conjunto com a forma com que as obras dos artistas foram expostas, revelam as estratégias - embora sutis - de demarcação de territórios. Na parte interna do Armazém, a luz incidia somente sobre as obras, de forma que, ao adentrar no espaço expositivo, que concentrava quase todas as obras - exceto duas: o Varal, já mencionado, que adentrava a cidade, e a língua metálica proposta por Raquel Baelles, que foi disposta na área externa entre o armazém e o mar -, as figuras inusitadas concebidas pelos designers passavam a formar uma massa densa com o público comum (Fig. 13).

Figura 13 - Obra iluminada e a performer mesclada ao público ao fundo

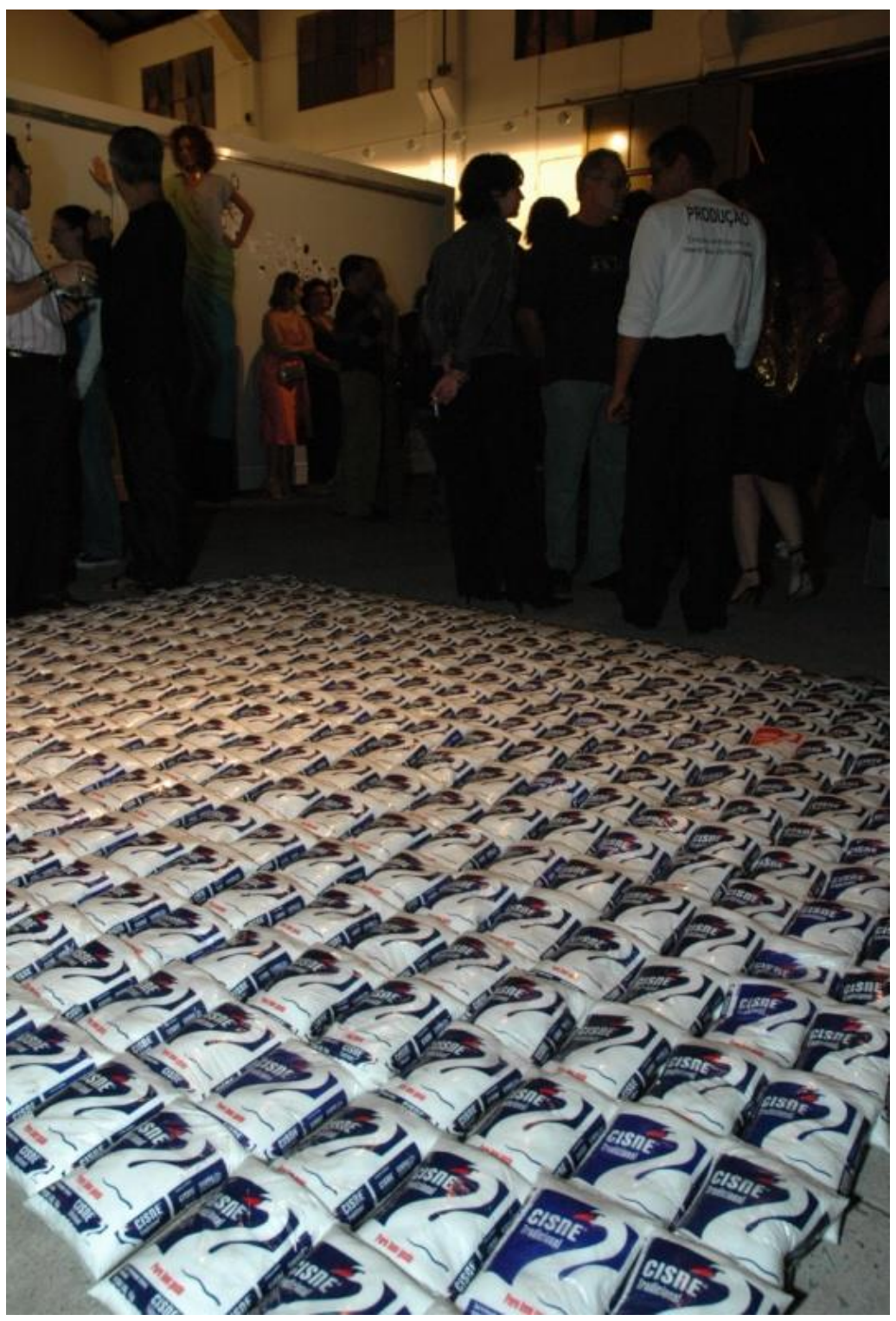

Fonte: Arquivo da autora. Foto de Marcos Salles (2006).

O caráter mais fluído das fronteiras da arte com outras áreas, presente no período mais recente, comumente designado de pós-modernismo, conforme dimensionou Andreas Huyssen (1996), 
não expurgou o legado herdado do paradigma moderno, particularmente fixado por meio das teorias de Adorno e Greenberg que governaram parte considerável das "sucessivas canonizações da obra de arte moderna" (FABRIS, 1994, p.13) ${ }^{235}$. Para Huyssen, o paradigma pós-moderno é "tão diverso e multifaceado como o modernismo o foi, antes de ser mumificado e virar dogma" (HUYSSEN, 1996, p.12). Segundo o autor, a revisão dicotômica entre alta e baixa cultura, incitada pelas vanguardas históricas, teria sido retomada apenas a partir dos anos de 1980 (1997, p.12) $)^{236}$. Por outro lado, mesmo com a retomada dessa agenda conciliatória, a herança da canonização da obra de arte promovida pelo modernismo ainda continuaria presente nas práticas do pós-modernismo: "O museu como templo, o artista como profeta, a obra como relíquia e objeto de culto, a aura restaurada" (HUYSSEN, 1992, p.17) 237 .

Englobar atividades diversificadas aos eventos de arte foi estratégia amplamente utilizada a partir dos anos de 1990 em importantes instituições de arte no exterior e no Brasil. A inclusão de outros segmentos da criação artística - mais atrativos ao grande público que a arte, particularmente a contemporânea - contribuía, entre outras possibilidades, para alargar 0 número de visitantes. $A$ aproximação entre arte e design de moda no $7^{\circ}$ Salão do Mar é tributária desse novo modelo que ajudava também a angariar visibilidade na mídia. É sintomático, nesse sentido, que a maior quantidade das reportagens veiculadas de forma espontânea na mídia televisiva abordou as ações da área de moda no Salão e não a exposição com as obras selecionadas 238 . Apesar de o espaço expositivo privilegiar as obras, no caso da mídia, a relação se invertia, em ambos os casos mostrando que os campos não se harmonizavam tão facilmente como previam os discursos. Esse espetáculo de variedades é típico da era de popularização dos museus como locais de entretenimento no final do século XX, essencialmente por seu caráter oposto à especialização ditado pela conduta modernista.

A incorporação da cultura de massa nos museus, que começou em torno dos anos de 1980, generalizando-se a partir dos anos de 1990, foi designada por Andreas Huyssen (1997) ${ }^{239}$ de

235 A autora utilizou como referência o livro After the great divide (1987) de Andreas Huyssen. FABRIS, Annateresa. Modernidade e vanguarda: 0 caso brasileiro. In: FABRIS, Annateresa (Org.). Modernidade e Modernismo no Brasil. Campinas: Mercado das letras, 1994.

236 Trata-se do que Huyssen denominou de Grande Divisor das águas. Segundo sua análise, as concepções de Adorno em relação ao obstáculo insuperável entre cultura de massa e cultura erudita predominaram no meio acadêmico entre a década de 1930 até de 1980, tendo sido substituídas pelo paradigma pós-moderno. HUYSSEN, Andreas. Memórias do Modernismo. Rio de Janeiro: UFRJ, 1997, p.12.

237 HUYSSEN, Andreas. Mapeando o pós-moderno. In: HOLLANDA, Heloisa Buarque de (Org.). Pós-modernismo e política. Rio de Janeiro: Rocco, 1992.

${ }_{238} \quad$ A afirmação possui como referência os dados levantados no clipping realizado pela Casa Porto das Artes Plásticas, que foram listados no relatório final do evento. Das 10 matérias televisivas mencionadas 7 foram sobre os desfiles de moda, que ocorreram por 3 dias no início do mês de julho de 2006.

239 HUYSSEN, Andreas. Memórias do Modernismo. Rio de Janeiro: UFRJ, 1997. 
museumania. Para o autor, essa alteração transformou o papel do museu: de guardião da tradição da alta cultura em "lugar de um mise-en-scène espetacular e de exuberância operística" (HUYSSEN, 1997, p.223). Esta virada no status museológico pode ser visualizada no processo inverso percorrido pelas grifes sofisticadas e as instituições museológicas no dinamismo entre mercantilismo e mito simbólico. Se por um lado, a tradição de luxo da alta costura expandiu sua influência dentro de importantes instituições culturais de arte, no exterior e no Brasil, como estratégia publicitária de legitimação das grifes ${ }^{240}$, por outro, com a disseminação de lojas nas instituições culturais, "a obra de arte original surge como um meio para vender seus múltiplos derivados, e a reprodutibilidade como uma estratégia para aureolar o original" (HUYSSEN, 1997, p.236).

Replicar o modelo dos grandes centros na periferia não significa necessariamente a obtenção dos mesmos resultados. Tendo como referência museus de maior porte, Huyssen afirmou que a receita proveniente das lojas de souvenires, muitas vezes, ultrapassava a arrecadação das bilheterias (1997, p.236). Incluir essas lojas nas instituições culturais, visando aumentar a receita, foi estratégia praticamente unânime que, no Brasil, muito provavelmente, só funcionou nos centros urbanos maiores. Alguns museus brasileiros, como foi o caso do MAM/SP (Museu de Arte Moderna de São Paulo), chegaram a abrir filiais em "endereços badalados" da cidade, ofertando uma extensa linha de produtos com sua marca além de peças de designers. Em 2009, foi divulgado no site desse museu que, cerca de $10 \%$ do seu faturamento anual era proveniente da venda dos produtos da ShopMAM, informando ainda que eles inauguraram dois espaços em shoppings da capital: Shopping Villa-Lobos e Shopping Iguatemi241. Em uma tentativa de aproximação com o modelo em voga, mesmo sem almejar obter retorno financeiro para a instituição, foi aberta uma "lojinha" durante a $7^{\text {a }}$ edição do Salão do Mar. 0 convênio assinado entre a Casa Porto das Artes Plásticas e o Sindicato dos Artistas Plásticos Profissionais do Espírito Santo (SINDIAPPES) estabelecia que o espaço da loja receberia peças de artistas, designers e artesãos. Além disso, a logomarca do evento foi disponibilizada para a produção de objetos destinados à comercialização sem qualquer espécie de retorno financeiro para a instituição. Entretanto, nenhum interessado apareceu. O espaço da loja serviu muito mais para a exposição das peças do que para efetuar vendas que, se ocorreram, foram irrisórias ${ }^{242}$.

240 O Metropolitan de Nova York, de forma pioneira, realizou em 1973 uma exposição com peças de Cristóbal Balenciaga e, em 1983, com trabalhos de Yves Saint Laurent. Esta prática, conforme apontou Adonay Ariza (2006, p.79), foi generalizada no final da década de 1990. ARIZA, Adonay. A moda como arte. In: MARGOTTO, Samira (Org.). Catálogo do $7^{\circ}$ Salão do Mar. Vitória: SEMC/PMV, 2006.

241 Disponível em: <http://lojasdemuseus.blogspot.com.br/2009/12/mammuseudeartecontemporanea_04.html >. Acesso em: 07 set. 2015.

242 Não foi localizado o registro de possíveis vendas ocorridas, a consideração acima leva em conta, somente a memória da autora. 
Se a abertura da loja no $7^{\circ}$ Salão do Mar visava apenas uma aproximação com os novos tipos de serviços ofertados dentro das instituições culturais em centros maiores, a tentativa de angariar recursos para o evento com a iniciativa privada ocorreu por meio da confecção de um projeto de captação de recursos, que seria apresentado em empresas maiores que possuíam sedes no Espírito Santo. Cerca de 100 ofícios foram enviados pelo Gabinete do Prefeito 243 solicitando que os responsáveis pelo Salão fossem recebidos, mas não houve sequer um retorno. Tal como nas edições anteriores da mostra, a participação da iniciativa privada ocorreu por meio de vínculos pessoais dos organizadores com alguns empresários. $O$ projeto de captação de recursos foi urdido com toda a retórica do período, associando a cultura e as artes ao crescimento econômico do país e do Espírito Santo, enfatizando ainda as ações que seriam desenvolvidas pela ação educativa, como peça fundamental do evento e que haveria a aproximação com outras áreas do setor criativo como a moda, o artesanato e a música. 0 item Cotas e retorno de mídia apresentou a inserção da logomarca do patrocinador, em maior ou menor destaque, nos materiais do evento e a menção da empresa nas entrevistas aos veículos de comunicação, como atrativo. Entretanto, o argumento - ao contrário do que ingenuamente foi suposto - poderia até mesmo afugentar o patrocínio: a única empresa de grande porte que contribuiu solicitou anonimato 244 .

\subsubsection{Demarcações}

Mesmo considerando a imprecisão dos registros feitos pelos contadores eletrônicos, cabe mencionar que o número de visitantes aferido no relatório do $7^{\circ}$ Salão do Mar foi de 1.264 pessoas no dia de sua inauguração e 14.890 até seu encerramento, em 21 de julho de 2006 (MARGOTTO, 2006a, p.13) 245 . Imagens da abertura (Fig. 09) confirmam a expressiva circulação nesse dia e dados retirados do relatório da ação educativa destacam que o contingente mais expressivo de visitantes, 73\%, compareceu ao local sem agendamento prévio, enquanto o número daqueles que agendaram previamente foi de $27 \%$. Conforme foi registrado no relatório, o público foi diversificado, composto por transeuntes, trabalhadores do Centro em horários de folga, artistas, agentes culturais, turistas etc.. Além desses, diversas escolas se deslocaram para o local, sem que o professor responsável tivesse

243 Os ofícios foram feitos no final de fevereiro de 2006 e encaminhados aos Diretores e Presidentes das empresas. O texto é sucinto e associa o Salão do Mar ao conjunto de comemorações do centenário do Porto de Vitória.

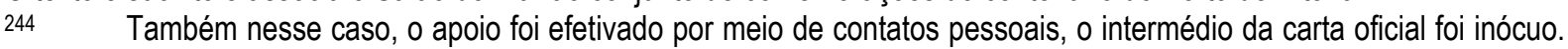
A doação foi atendida, porém, quando foi solicitado o envio da logomarca para constar nos materiais do evento, o pedido de não inserção foi justificado mencionando que em todas as ocasiões que a logomarca da empresa aparecia em eventos semelhantes, ocorria um aumento de procura por patrocínio.

245 MARGOTTO, Samira (Coord.). Relatório do $7^{\circ}$ Salão do Mar. Vitória: SEMC/PMV, 2006a. Cabe ressaltar que os dados foram coletados e sistematizados, com o auxílio da Carolina Corres Lopes (assessora técnica) e de Beatriz Sodré, Fabiola Menezes, Melissa Guizzardi, Victor Monteiro e Johnny Loureiro (estagiários da Casa Porto). 
frequentado o curso de formação ou agendado a visita com o setor educativo (CIRILLO, 2006, p.6 e 7) 246 .

Duas questões complementares podem ser extraídas das informações acima, ambas relacionadas à importância concedida à noção da ampliação do acesso de um público diversificado nos eventos de arte e às estratégias utilizadas para demonstrar seu êxito. A primeira é relativa à introdução desses contadores eletrônicos, popularmente designados de catracas. Eles são indissociáveis do novo modelo de financiamento da cultura com a expansão das leis de incentivo fiscal, especialmente a Lei Rouanet, que paulatinamente, transferiu decisões de ações culturais para os patrocinadores. Dentro desse novo modelo, cresceu a noção de exposição como espetáculo que vinculou a quantidade aferida de visitantes ao sucesso dos eventos.

Foi na década de 1990 que grandes museus brasileiros, seguindo uma tendência mundial, começaram a substituir o livro de assinaturas pela utilização "[...] dos contadores automáticos ou bilheteria"247, conforme detectou Marilúcia Bottallo (2001, p.23). Mudança que, para a autora, indicou uma "[...] nova mentalidade que buscava incluir o museu no circuito dos meios de comunicação de massa. Assim, passa a ser necessário, antes de conhecer o perfil do público, quantificá-lo" (2001, p.23). Quantificar o público, conforme foi exposto, tanto poderia significar angariar recursos quanto reportagens jornalísticas, não deixando de refletir duas faces da mesma moeda. 0 antigo livro de assinaturas foi sendo abolido pela imprecisão de sua função de registro, que não chegava a oficializar a clientela das instituições e comprometia a própria sobrevivência desses espaços culturais, já que os patrocinadores, dos quais dependiam cada vez mais, passaram a medir o sucesso de uma exposição pelo número aferido de visitantes. Essa lógica foi incorporada também pelo poder público: contabilizar o número de visitantes ajudava, como no caso da $7^{\text {a }}$ edição do Salão do Mar, a justificar os gastos com o evento, demonstrar sua importância para a sociedade e, como consequência, dispor de recursos financeiros para a concretização do mesmo nos anos seguintes.

A segunda questão pode ser extraída de outras ações com ambições sociopolíticas de inclusão que ecoaram dessas reconfigurações no campo da arte. Em 2004, por exemplo, a Bienal de São Paulo

246 CIRILLO, Aparecido José. Relatório da Ação Educativa do $7^{\circ}$ Salão do Mar. Vitória: LEENA; SEMC/PMV, 2006. $O$ relatório pode ser consultado tanto nos arquivos da Casa Porto das Artes Plásticas quanto no Laboratório de estudos e ensino da arte (LEENA), no Centro de Artes da UFES. Ressalta-se que tanto esse relatório quanto outros documentos mencionados, especialmente, sobre a sétima e a oitava edição do evento, são cópias digitais do arquivo pessoal da autora que, no período era funcionária da Secretaria Municipal de Cultura e atuou na equipe de organização dos dois eventos.

$247 \quad$ Em nota de rodapé a autora cita alguns exemplos: Pinacoteca do Estado de São Paulo (1995); Museu de Arte Moderna de São Paulo (1994) e o MASP (1991). Ver: BOTTALLO, Marilúcia. Arte moderna e contemporânea em São Paulo: o museu como intermediário. 2001. Dissertação (Mestrado em Comunicações e Artes) - Escola de Comunicações e Artes/Universidade de São Paulo. São Paulo, 2001. 
tornou o evento gratuito - registrando 917.2018 visitantes ${ }^{248}$, número recorde em relação às edições anteriores -, política que permaneceu nas suas edições posteriores ${ }^{249}$. Conforme sublinhou Rita Alves Oliveira (2001) $)^{250}$, o setor educativo foi sendo ampliado, especialmente a partir da 24a Bienal em 1998. Segundo a autora, essa edição foi tracejada sobre três eixos que representavam as linhas de atuação do evento e também "as bases para a captação de recursos com a iniciativa privada": exibição, educação e edição (OLIVEIRA, 2001, p.27). O "resultado foi um megaprojeto de educação envolvendo um intenso programa de cursos e seminários que atingiu mais de mil profissionais do ensino público e quase 120 mil alunos da rede pública que tiveram ingressos gratuitos" (OLIVEIRA, 2001, p.27).

Essas alterações no setor educativo nas instituições de arte no Brasil não teriam sido possíveis sem as condições históricas necessárias para sua remodelação: em 1988 ocorreu a promulgação da nova Constituição brasileira que introduziu a expressão "direitos culturais", seguida pelas discussões sobre a nova Lei de Diretrizes e Bases da Educação Nacional 9394/96, sancionada em dezembro de 1996, que tornou obrigatório o ensino de arte nas escolas ${ }^{251}$. Tais mudanças impulsionaram a criação de cursos graduação e pós-graduação, muitos dos quais, voltados para a relação entre arte e educação, ampliando, consequentemente, o número de profissionais do setor e as reflexões nas práticas e estratégias adotadas nas instituições culturais.

Contratar profissionais especializados e produzir materiais atraentes fez crescer os investimentos no setor educativo nos eventos de arte. Acompanhando os dados apresentados nos

248 A informação consta em reportagem do jornal Folha de S. Paulo (21/12/2004), no qual, é afirmado que os dados foram fornecidos pela assessoria da Fundação Bienal. $O$ texto também sublinha que a Fundação Bienal encomendou uma pesquisa ao Instituto Datafolha. No levantamento, que ouviu 764 pessoas, mais da metade do público nunca havia visitado uma Bienal. Disponivel em: <http://www1.folha.uol.com.br/folha/ilustrada/ult90u48592.shtml>. Acesso em: 02 nov. 2017.

249 A informação consta no site da instituição. Disponível em: <http://www.bienal.org.br/exposicao.php?i=2343>. Acesso em: 03 nov. 2017.

250 OLIVERIA, Rita Alves. Bienal de São Paulo: impacto na cultura brasileira. São Paulo Perspec., São Paulo , v. 15, n. 3, p.18-28, Jul. 2001. Disponível em: <http://www.scielo.br/pdf/spp/v15n3/a04v15n3.pdf>. Acesso em: 04 nov. 2017.

${ }_{251} \quad$ A Lei de Diretrizes e Bases da Educação Nacional reorganizou também as licenciaturas por áreas específicas, retirante 0 atributo ambivalente dos antigos cursos de Licenciatura em Educação Artística, estabelecidos pela Reforma Educacional de 1971. Nesta última, as artes plásticas, a música e as artes cênicas eram ensinadas por um mesmo professor da primeira à oitava série do antigo primeiro grau. Em 1973, os cursos foram divididos em Licenciatura curta (com duração de dois anos) e plena. Para obter a Licenciatura Plena, era necessário prosseguir os estudos e escolher a habilitação. Cabe ressaltar que, as pesquisas e atuação de Ana Mae Barbosa foram de fundamental importância na alteração desse quadro. Além de questionar a legislação em vigor, ela também foi pioneira no Brasil na defesa da importância da apreciação crítica e da história da arte nas escolas, por meio de sua conhecida Proposta Triangular. Conforme sintetizou a autora: "A Proposta Triangular começou a ser sistematizada em 1983 no Festival de Inverno de Campos de Jordão, em São Paulo e foi intensamente pesquisada entre 1987 e 1993 no Museu de Arte Contemporânea da Universidade de São Paulo e na Secretaria Municipal de Educação sob o comando de Paulo (Reglus Neves) Freire e Mário (Sérgio) Cortella" (2008, p.14). As informações apresentadas tiveram como base as seguintes fontes: BRASIL. Ministério da Educação e Cultura. Conselho Nacional de Educação. Diretrizes e Bases de $1^{\circ}$ e $2^{\circ}$ graus. Lei 5.962, de 11 de agosto de 1971; BRASIL. Ministério da Educação e Cultura. Lei № 9.394, de 20 de dezembro de 1996; BARBOSA, Ana Mae. Teoria e prática da educação artística. São Paulo: Cultrix, 1975; BARBOSA, Ana Mae; FERRARA, Lucrécia D'Alessio; VERNASCHI, Elvira (Orgs.). 0 Ensino das Artes nas Universidades. São Paulo: EDUSP, 1993; BARBOSA, Ana Mae (Org.). Ensino da arte: memória e história. São Paulo: Perspectiva, 2008. 
catálogos do Salão do Mar, entre sua edição inicial (1999) até $6^{a}$ edição (2004) e, da $7^{a}(2006)$ à $8^{a}$ (2008), é possível detectar com clareza esse processo ao longo dos anos de realização do evento. Se na primeira (1999) e na segunda (2000) edição não há qualquer alusão nos catálogos que possa indicar a ocorrência de atividades educativas, na terceira (2001) e quarta edição (2002), monitores são citados $^{252}$. Nesta última, assim como na seguinte (2003), é mencionada pela primeira vez a função de coordenação de monitoria, sendo que na sexta (2004), o cargo não aparece, e apenas os nomes de duas monitoras foram registrados. Foi somente na sétima edição (2006) que o Salão do Mar contratou uma equipe mais ampla de profissionais para conceber um projeto educativo e investiu na confecção de materiais específicos para atender o público 253 . Três professores da UFES254 foram responsáveis por conduzir as ações ao longo do evento, com o auxílio de uma equipe formada por doze pessoas, entre monitores e oficineiros, graduandos ou graduados dos cursos de artes da UFES. O número de profissionais envolvidos na edição seguinte (2008) na Ação Educativa foi ainda maior, composto por dois membros responsáveis pela Coordenação e Organização e, outros dois que exerceram a função de Coordenação Operacional e Pedagógica ${ }^{255}$, com a colaboração de quinze mediadores.

É necessário ressaltar, contudo, que a ampliação do investimento financeiro, a contratação de um número cada vez mais extenso de profissionais, tanto para mediar quanto coordenar, não significou, necessariamente, uma alteração mais substancial no status historicamente reservado ao setor educativo dentro dos espaços da arte. A manutenção da hierarquia pode ser detectada, por exemplo, na não inclusão de textos com reflexões sobre as ações desenvolvidas pelo setor educativo no principal material de registro do evento: o catálogo. Neste, o destaque é para a análise dos curadores sobre as obras. Existe, portanto, o discurso oficial, e o outro, que possui o "público organizado" como destinatário, elaborado pelas ações educativas e, normalmente, distribuído em material paralelo e para grupos singulares. Por um lado, os catálogos são disseminados pelo país pela instituição promotora do evento (como foi o caso da $7^{\mathrm{a}}$ e $8^{\mathrm{a}}$ edição do Salão do Mar) para bibliotecas, secretarias de cultura, artistas e curadores que participaram do evento etc., tendo a função de divulgar e registrar a exposição. Por outro, o trabalho desenvolvido pelo setor educativo, normalmente, não

\footnotetext{
252 Os monitores, nessas primeiras edições, eram jovens moradores da comunidade do Morro do forte São João, localizada na região do Centro de Vitória, onde fica a Casa Porto das Artes Plásticas. Na edição de 2001, foi possivelmente a própria Coordenadora da Casa Porto, Tereza Norma Borges Tommasi, quem instruiu os monitores. Em 2002 e 2003, a artista plástica Berenice Viana exerceu a função de Coordenação de monitoria. Ressalta-se que, na edição de 2004, as duas monitoras mencionadas, Melina Almada Sarnaglia e Nívea Valéria dos Santos, eram estudantes de artes na UFES.

${ }_{253} \mathrm{O}$ material impresso foi dividido em três "Rotas", sendo destinado respectivamente aos professores da educação infantil, ensino fundamental e ensino médio. 0 material digital, um CD-ROM interativo, tinha como alvo atender tanto agentes culturais quanto professores.

$254 \quad$ Os responsáveis foram: Moema Rebouças, Maria Auxiliadora Corassa e José Cirillo.

255 José Cirillo e Neusa Mendes eram os membros da Coordenação e Organização da Ação Educativa, enquanto a Coordenação Operacional e Pedagógica foi desenvolvida por Célia Ribeiro e Erly Vieira Júnior.
} 
ultrapassa os limites locais ${ }^{256}$ e do seu público específico: a distribuição do material é realizada, sobretudo, durante os cursos de formação preparatórios destinados a instrumentalizar os professores que atuarão como difusores ou, ainda na ocasião das visitas desses grupos ao espaço expositivo.

Conforme analisou Andrew McClellan (2004, p.1 e 2)257, os museus são guiados por ideais de acesso democrático, utopia otimista que sustentou historicamente a crença no potencial transformador da arte. Tal crença teria sido ampliada na era romântica e reforçada nas décadas mais recentes diante de uma sequência de transtornos sociais. Sem endossar essa retórica, o autor expõe as tensões subjacentes dentro das declarações (de viés democrático) que regem as missões dos museus de arte, considerando as diferenças de atribuição entre curador e educador em relação ao visitante. Para tanto, ele enfatizou que, dentro das instituições museológicas, a atribuição primordial do curador - pela tradição histórica - é cuidar do acervo. Esse acervo, por sua vez, é apresentado ao público permeado de restrições de acesso, com o intuito de preservar os objetos para a posteridade (é possível acrescentar que, uma vez incorporadas aos acervos, obras produzidas para serem interativas, predominantemente, só cumprem essa função por meio de réplicas. Ou seja, as obras originais são guardadas e têm sua gênese deturpada pelos responsáveis por sua disseminação). Portanto, o compromisso tradicionalmente atribuído ao curador é garantir a integridade desses objetos para um fictício público futuro. Enquanto os cuidados com o público do presente "são deixados em grande parte aos educadores e voluntários, que ocupam um lugar menos privilegiado na hierarquia do museu" (McCLELLAN, 2004, p.2).

\subsection{3 - Público: uma rota entre tantas}

Indagar sobre demarcações e hierarquias entre os enunciadores dos discursos no campo da arte compele também a pensar em outros aspectos relacionados à renovada importância conferida à categoria "público" nas últimas décadas. Se todo museu tem seu público, uma pergunta salutar é quem é esse coletivo, o público? Andrew McClellan, em A brief history of the art museum public (2004), afirmou que é impossível conceber os visitantes como uma homogeneidade abstrata, um "público". Se os espectadores são diversos em interesse, conhecimento, classe social, raça, etnia e gênero,

256 Conforme foi apresentado no relatório da Ação Educativa do $7^{\circ}$ Salão do Mar, $60 \%$ dos visitantes eram oriundos da Grande Vitória, $15 \%$ de municípios do interior do Espírito Santo e $25 \%$ de origens diversas. CIRILLO, José. Relatório da Ação Educativa. 2006, p.8.

257 McCLELLAN, Andrew (Ed.). Art and its Publics: Museum Studies at the Millennium. London: Blackwell Publishing, 2004. 
conforme afirmou o autor ${ }^{258}$, eles, entretanto, de forma ampla, são segmentados em dois núcleos dentro dos espaços culturais: o público espontâneo e o organizado. Se o primeiro é sempre mais heterogêneo e sua participação, como o próprio termo indica, pode ser apenas prevista, a visitação do segundo núcleo é praticamente assegurada. Não sem razão, de forma genérica, na elaboração dos materiais educativos nessas instituições o denominado público organizado é mais privilegiado. Esse público, preponderantemente, é formado por alunos das instituições formais de ensino e o material elaborado é dirigido - de forma geral - para que os professores preparem os estudantes para a visitação e, posteriormente, desenvolvam atividades em sala de aula.

Foi na $7^{a}$ edição do Salão do Mar que a preocupação em atender de forma diferenciada 0 público escolar foi estabelecida ${ }^{259}$. Na proposta apresentada pela Fundação Ceciliano Abel de Almeida (FCAA) em parceria com o Laboratório de Estudos e Ensino da Arte (LEENA), ambos vinculados à UFES, para a Casa Porto das Artes Plásticas estava prevista a realização de cursos de capacitação para professores das redes municipal, estadual e particular de ensino ${ }^{260}$, além da distribuição de material específico para atender esse grupo. 0 material de apoio consistiu em folders, destinados respectivamente, à educação infantil, à educação fundamental e ao ensino médio, além de um CDROM interativo. Neste último foi disponibilizado um conteúdo mais amplo - englobando o material impresso, as propostas enviadas pelos artistas, a ficha técnica do Salão etc. - , devido ao custo reduzido e à possibilidade de sua reprodução. O CD-ROM foi distribuído tanto para professores quanto agentes culturais. A metodologia adotada foi centrada em três princípios: vivência, experimentação e confronto. Tais princípios foram apresentados como complementares entre si e orientaram o conteúdo das três rotas possíveis para a mostra: a primeira foi destinada à educação infantil, a segunda, como sendo mais adequada aos alunos do ensino fundamental e, a terceira ao ensino médio. Cabe sublinhar que o material de apoio era um referente, uma possibilidade, "uma 'rota entre tantas'" (CIRILLO, 2006, p.4, grifo do autor).

A proposta desenvolvida, no evento de 2006 , refletia as mudanças na política educacional do ensino da arte (as premissas estabelecidas nos Parâmetros Curriculares Nacionais, os PCN's e as

\footnotetext{
258 Ao introduzir a questão, Andrew McClellan, resgata um escrito do pintor Charles-Antoine Coypel, realizado há mais de duzentos e cinquenta anos, mencionado por Thomas Crow. Neste, Coypel questionava o caráter singular utilizado para descrever as multidões que compareciam as exposições realizadas no Museu de Louvre. Para McClellan, essa diversidade real apresenta um nítido contraste com a unidade fictícia que o termo público abarca. 0 autor associa essa noção de unidade aos ideais historicamente associados aos museus, como devendo fornecer um serviço público e acesso democrático à população. MCCLELLAN, Andrew. A brief history of the art museum public. In: MCCLELLAN, Andrew (Ed.) Art and its publics: Museum studies at the millennium. Blackwell Publishing, 2004, p.1.

259 Tal afirmação considera os registros das ações anteriores que constam nos catálogos do evento. Antes, 0 atendimento era destinado a um público genérico, conforme já foi exposto.

260 No relatório da Ação Educativa consta que 99 professores frequentaram o curso preparatório ofertado (CIRILLO, 2006, p.8).
} 
diretrizes curriculares do ensino da arte, por exemplo, são mencionadas) e, por conseguinte, a disseminação das ações educativas dentro dos espaços culturais. Pontos, aliás, que estão interligados, visto que cada vez mais, foi ressaltada nos documentos oficiais do ensino da arte a importância da contextualização e a análise das obras, em substituição ao conceito anterior, mais voltado para o desenvolvimento de atividades de produção artística nas salas de aula.

Se essas ações desenvolvidas pela ação educativa no $7^{\circ}$ Salão do Mar são, portanto, tributárias do contexto educacional brasileiro da arte e seus desdobramentos no âmbito das instituições culturais, torna-se necessário ampliar a discussão além das pretensões e dos resultados desse evento específico. É preciso indagar sobre esse interesse em investir no público organizado, além do discurso de caráter inclusivo apregoado nos espaços culturais com suas boas intenções de oferecer um serviço amplo, democrático e contribuir para o refinamento intelectual e a formação de princípios comuns de gosto, bem como, da conveniência tática em ampliar o número de visitantes. $\mathrm{Na}$ edição seguinte (2008), quando o evento foi realizado no espaço urbano, as práticas pedagógicas empregadas tiveram que ser revistas. Se dentro do espaço do armazém era possível traçar rotas de orientação, no espaço aberto das ruas, a dificuldade tanto de precisar o público, quanto de estabelecer itinerários que norteassem o deslocamento, criaram outras incertezas, na dissonância de ecos dos vários regimes culturais em circulação.

Roger Chartier, no texto Cultura popular: revisitando um conceito historiográfico (1995)261, partiu da premissa que o "popular" é uma categoria erudita e que os debates a respeito da definição daquilo em que consiste são realizados em torno de um conceito com a pretensão de delimitar, caracterizar e nomear práticas nunca designadas pelos seus atores. Para ele, existem dois grandes modelos de descrição e interpretação. O primeiro, com a intenção de abolir toda forma de etnocentrismo cultural, idealiza a cultura popular como um sistema simbólico coerente e autônomo que opera segundo uma lógica alheia e irredutível à da cultura letrada. 0 outro modelo, "preocupado em lembrar a existência das relações de dominação que organizam o mundo social, percebe a cultura popular em suas dependências e carências em relação à cultura dos dominantes" (1995, p.179). Um museu, lugar de canonização da cultura (erudita ou não), tem de se haver com essas delimitações a todo tempo, pois vive na intersecção entre centro erudito e periferias populares. Dessa forma, não importa o objeto de análise, as relações que implicam tentativas de dominação no mundo social guardam semelhanças, podendo estar revestidas com uma retórica sedutora, porém, de forma genérica, trazem embutida a presunção de entender e saber como suprir as faltas do outro.

261 Cf: CHARTIER, Roger. Cultura popular: revisitando um conceito historiográfico. Estudos Históricos. Rio de Janeiro, vol. 8, n. 16, 1995, p.179-192. 


\subsection{RECONCEITUAÇÕES: ESPAÇOS ALTERNATIVOS E PRODUÇÃO}

A utilização do armazém portuário na $7^{a}$ edição do Salão do Mar é tributária das tentativas de reconceituar os modos de exibição da arte contemporânea que acompanham as discussões envolvendo arte e democracia. 0 modelo cubo branco, espaço considerado distanciado da realidade mundana, dentre outros fatores, por confinar a produção a uma frieza convencional nas apresentações 262 , foi sendo redefinido dentro das proposições de caráter participativo das últimas décadas. Se os questionamentos dos padrões do "cubo branco" são encadeamentos de uma tradição proveniente desde o segundo pós-guerra mundial263, a partir da década de 1990, eles ganharam novo impulso. Claire Bishop (2004) ${ }^{264}$ observou, tendo por mote a abertura do Palais de Tokyo, em 2002, que o paradigma do cubo branco estava sendo substituído pelo modelo de "estúdio" ou "laboratório", mais condizente com a produção recente e seus "trabalhos abertos, interativos, resistentes ao fechamento, muitas vezes aparentando estar 'em andamento' diversamente de objetos prontos" (2004, p.52, grifo da autora). Esse modelo foi relacionado por Bishop à tendência de convidar artistas a desenvolver trabalhos interativos nesses ambientes. A autora destacou a relação improvisada dos ambientes no Palais de Tokyo com o interior vazio e inacabado, apesar do elevado orçamento destinado a converter 0 antigo pavilhão japonês para a Feira Mundial de 1937 em lugar para a criação da arte contemporânea: 4,74 milhões de euros (BISHOP, 2004, p.51).

De certa forma, reverberações dessa tendência podem ser detectadas na edição do $7^{\circ}$ Salão do Mar. Se no caso do Palais de Tokyo, a noção de improvisação foi propositalmente criada, no caso capixaba, a utilização de um armazém portuário trouxe impasses reais vinculados ao uso de espaços alternativos, sem orçamentos vultosos para aplacar interferências diversas: da infestação de ratos e pombos (que danificaram algumas obras) ${ }^{265}$, até alagamentos provocados pelas rachaduras no telhado. 0 convite à interação, apontado por Bishop, no regulamento do $7^{\circ}$ Salão do Mar aparece de forma dúbia - ao mesmo tempo em que indicava medidas máximas para a apresentação das obras também afirmava que aquelas que excedessem as especificações seriam analisadas pelas Comissões, além de outras restrições, incluindo a exclusividade do conceito da montagem aos organizadores. $E$, apesar de confiar apenas à organização 0 arranjo das obras no espaço expositivo, imagens com 0

\footnotetext{
262 Vale lembrar que esses questionamentos acerca da ideologia do cubo branco estão presentes nas discussões nas décadas de 1960 e 1970. Nesse sentido, Brian Holmes (2008, p.7) sublinhou as contribuições de Yves Klein, Robert Smithson e a tese de Brian O'Doherty.

263 Presente, por exemplo, nas dimensões avantajadas das pinturas de Jackson Pollock e outros trabalhos de grande porte realizados por artistas como Carl Andre, Donald Judd e Richard Serra.

${ }_{264}$ BISHOP, Claire. Antagonism and relational aesthetics. October. N.110, fall 2004, pp.51-79. Disponível em: <http://academicworks.cuny.edu/cgi/viewcontent.cgi?article=1095\&context=gc_pubs>. Acesso em: 20 Mai. 2017.

265 Os fios de Paisagem sonora do Porto de Vitória de Luciana Ohira e Sérgio Bonilha, por exemplo, foram corroídos por ratos e, algumas das fotografias de Mares Edificados de Fabio Okamoto foram danificadas por fezes de pombos.
} 
armazém vazio foram disponibilizadas aos interessados em participar, convidando ao diálogo interventivo com o armazém (Figs. 14, 15, 16 e 17). É necessário esclarecer que quando o edital foi lançado, em dezembro de 2005, a utilização do armazém era apenas uma possibilidade, que só foi concretizada por meio de um convênio entre a SEMC/PMV e a Companhia Docas do Espírito Santo (CODESA), alguns dias antes do prazo previsto para o início do processo seletivo, realizado em março de 2006. Portanto, não se sabia ao certo se o evento poderia ocupar o espaço portuário ou teria que utilizar a sede da Casa Porto. Deve-se possivelmente ao caráter dúbio da informação do edital, o fato que, dos 27 artistas selecionados, apenas uma minoria das propostas dialogou de forma específica com o espaço expositivo proposto.

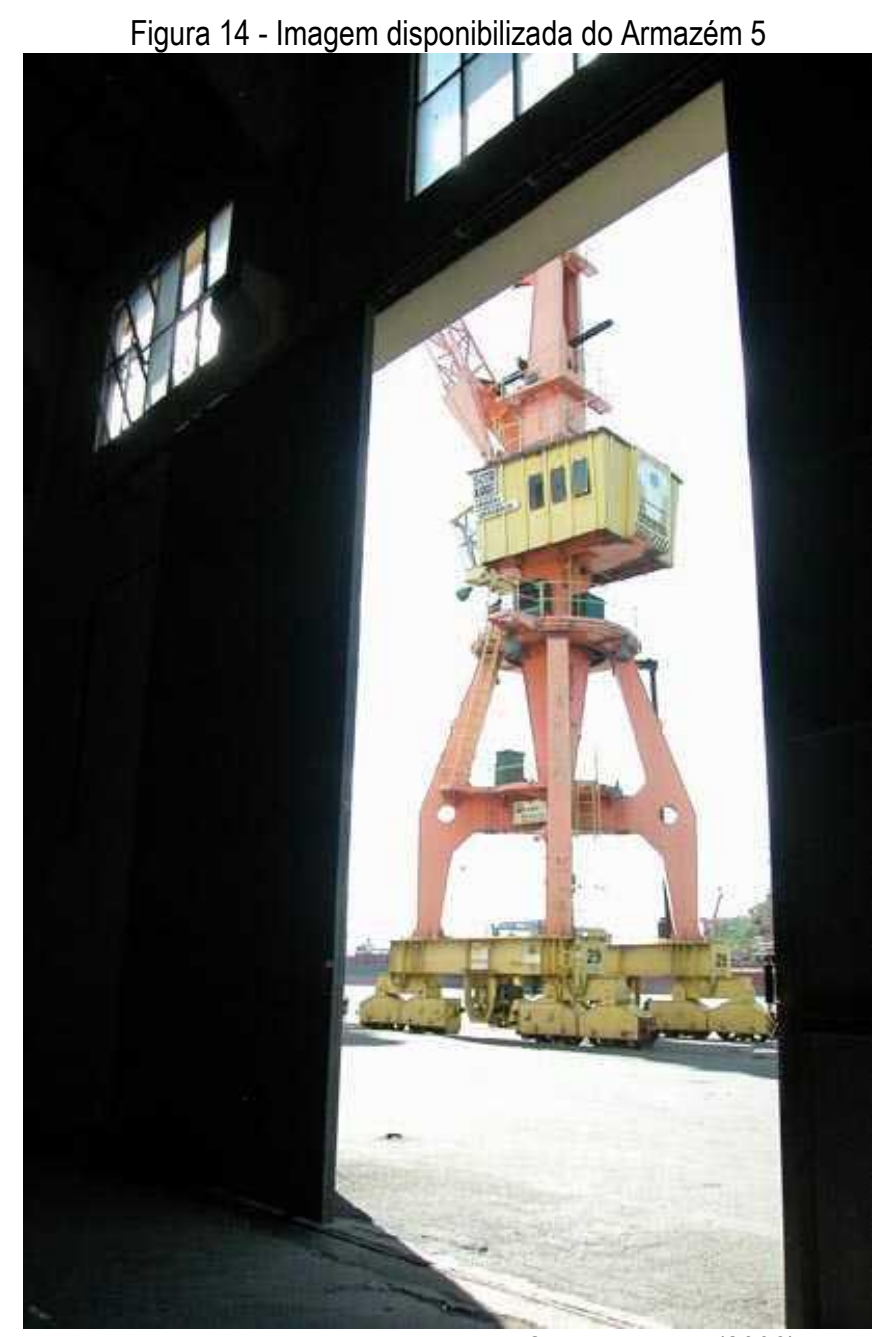

Fonte: Arquivo da autora. Foto de Carlos Antolini (2006).

Figura 15 - Imagem disponibilizada do Armazém 5 


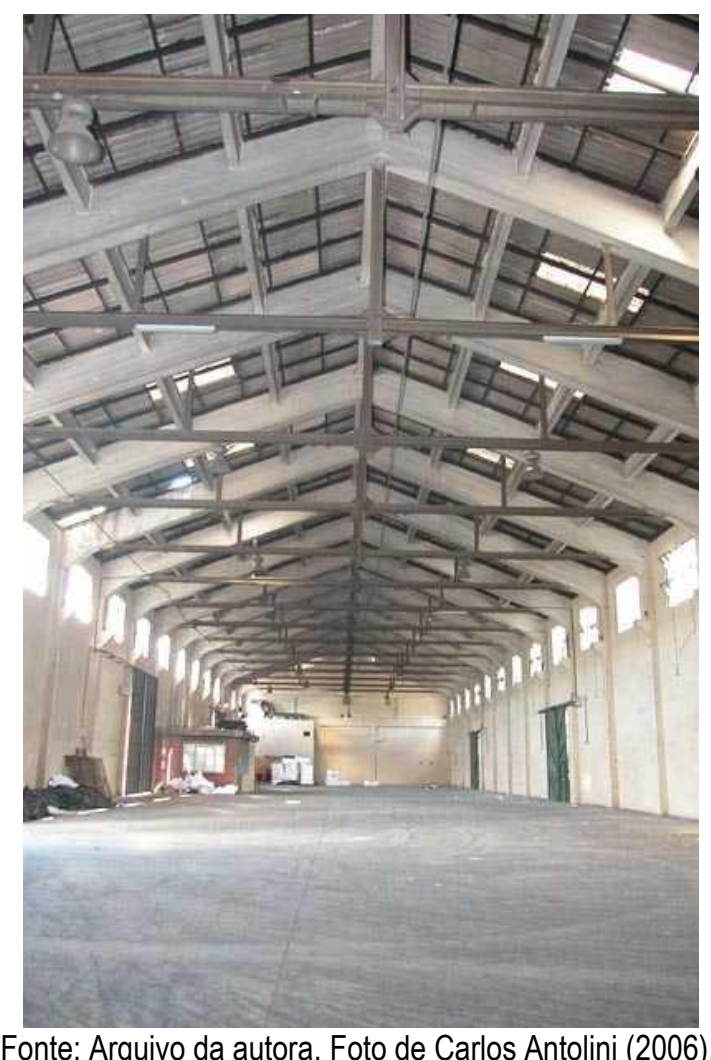

Fonte: Arquivo da autora. Foto de Carlos Antolini (2006).

Figura 16 - Imagem disponibilizada do Armazém 5

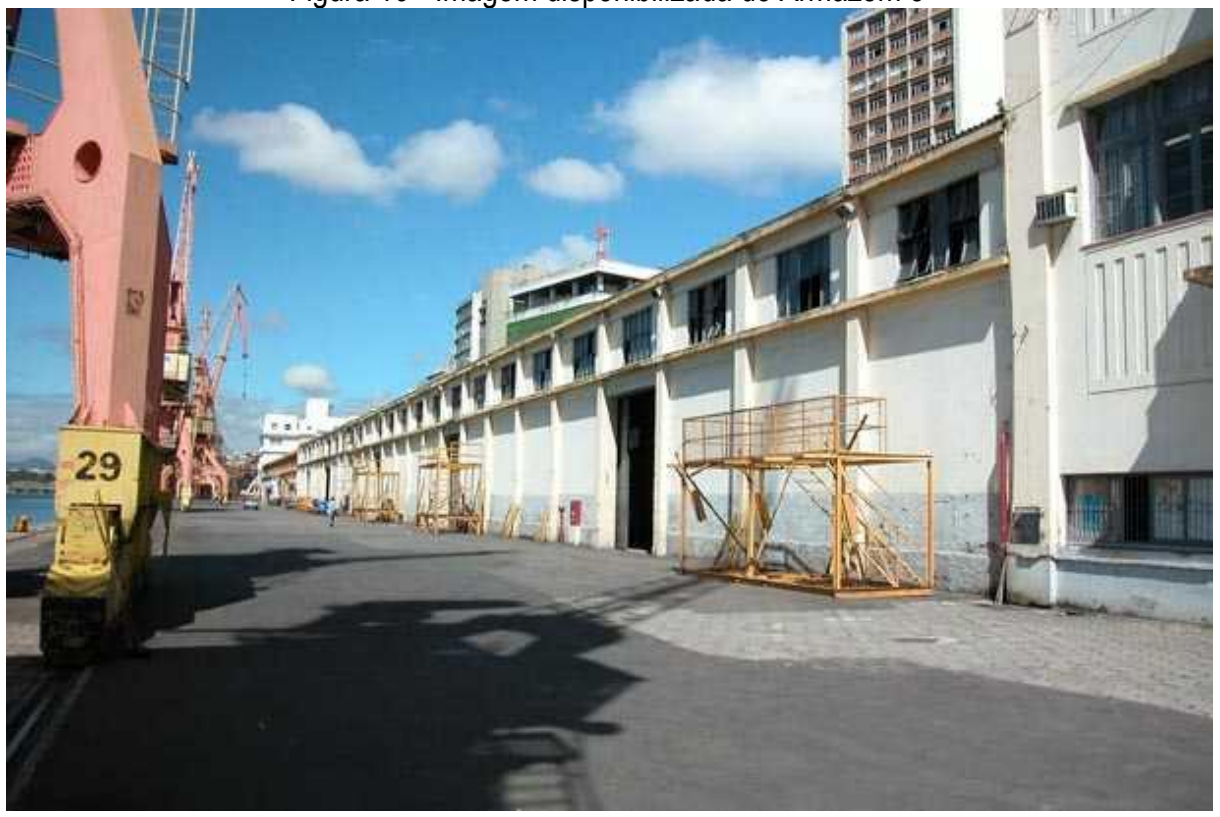

Fonte: Arquivo da autora. Foto de Carlos Antolini (2006). 


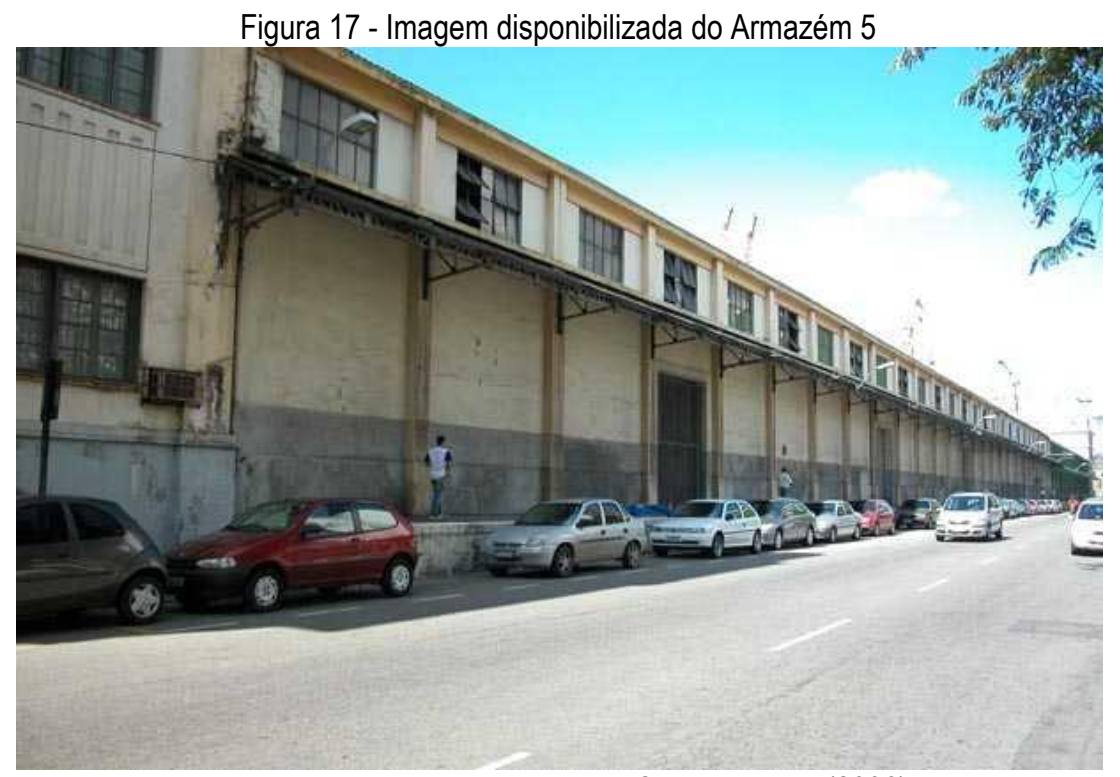

Fonte: Arquivo da autora. Foto de Carlos Antolini (2006).

O diálogo interventivo com o armazém, a noção de participação e o acentuado interesse em dialogar com o tecido urbano serão tomados como eixos para analisar os trabalhos apresentados no $7^{\circ}$ do Salão do Mar. Vale ressaltar que em algumas obras, essas questões estão entrelaçadas. Dessa forma, a divisão possui como intuito, sublinhar quando foi detectado um acento mais expressivo de cada um dos três eixos mencionados.

Em relação ao diálogo interventivo com o armazém, os exemplos mais proeminentes foram Paisagem sonora do Porto de Vitória, de Luciana Ohira e Sérgio Bonilha, Caximiti, de Isadora Bonder, Corredor do Mar, de Silfarlem de Oliveira, a plotagem Sem Título, de Dayse Resende e Varal, de Lourival Cuquinha Batista.

Luciana Ohira e Sérgio Bonilha, em Paisagem sonora partem da premissa que a noção de paisagem é frequentemente associada apenas ao aspecto visual, ignorando o olfato e o som. Assim, os artistas buscaram tornar evidentes camadas auditivas do Porto de Vitória, reunindo barulhos captados da superfície e abaixo da linha d'água. Segundo eles, "[...] se nos sobra fôlego para olhar o mar, nos falta ar para ouvir seus ruídos submersos e faltam-nos também melhores ouvidos para escutar os ruídos da superfície" (OHIRA; BONILHA, 2006). Já Isadora Bonder, em Caximiti (Fig. 18), utilizou um barco em desuso, bastante deteriorado pelo tempo e dentro inseriu a frase "[...]. Após o retorno mais tarde, quisera narrar minha aventura aos curiosos de sonhos [...]" (BONDER, 2006). Dayse Resende também usou o recurso poético para corporificar sua proposta de deslocamento da risca do mar para 0 espaço expositivo: "Todas as águas confluem para o mar, sem enchê-lo. Todas as águas saem do mar, sem esvaziá-lo" (RESENDE, 2006) foi plotada sobre a porta do armazém de acesso ao mar. Em Corredor do Mar, Silfarlem de Oliveira dispôs dois vídeos, um defronte ao outro. Um dos monitores 
exibia imagens e sons de "[...] uma porta aberta para o mar", enquanto o outro mostrava "[...] silenciosamente os registros das paredes", nos quais estavam ambos instalados (COCCHIARALE, 2006, p.37). As imagens afrontadas se revezavam depois de algum tempo, criando "[...] um corredor virtual, um percurso ausente da arquitetura do Salão, mas que se realiza em imagem". Assim, "[...] trata-se de indicar numa escala doméstica o lapso temporal de um percurso plausível entre as áreas interna e externa ao evento" (COCCHIARALE, 2006, p.37). A intervenção proposta por Lourival Cuquinha Batista, um Varal agigantado que saia do espaço expositivo e atravessava a Avenida Getúlio Vargas - transitando literalmente entre o recinto interior e o externo - expunha no espaço urbano memórias particulares: uma corda de seda sustentava roupas doadas ao artista por moradores de Vitória. Assim, "[...] o trabalho pertence à memória das pessoas que completam seus panos e interagem com a cidade" (CUQUINHA, 2006). 0 artista parte de uma ação corriqueira dos moradores do bairro de Santo Amaro, no Recife (cidade de origem do artista) - na "marginal da Avenida Agamenon Magalhães as pessoas se apropriam do espaço urbano para secarem suas roupas" (CUQUINHA, 2006). E propõe, a partir dessa atividade ordinária, uma intersecção entre o espaço urbano e o expositivo, evidenciando condutas que ocorrem à margem das tentativas de ordem e controle do cenário citadino.

Figura 18 - Caximiti, de Isadora Bonder

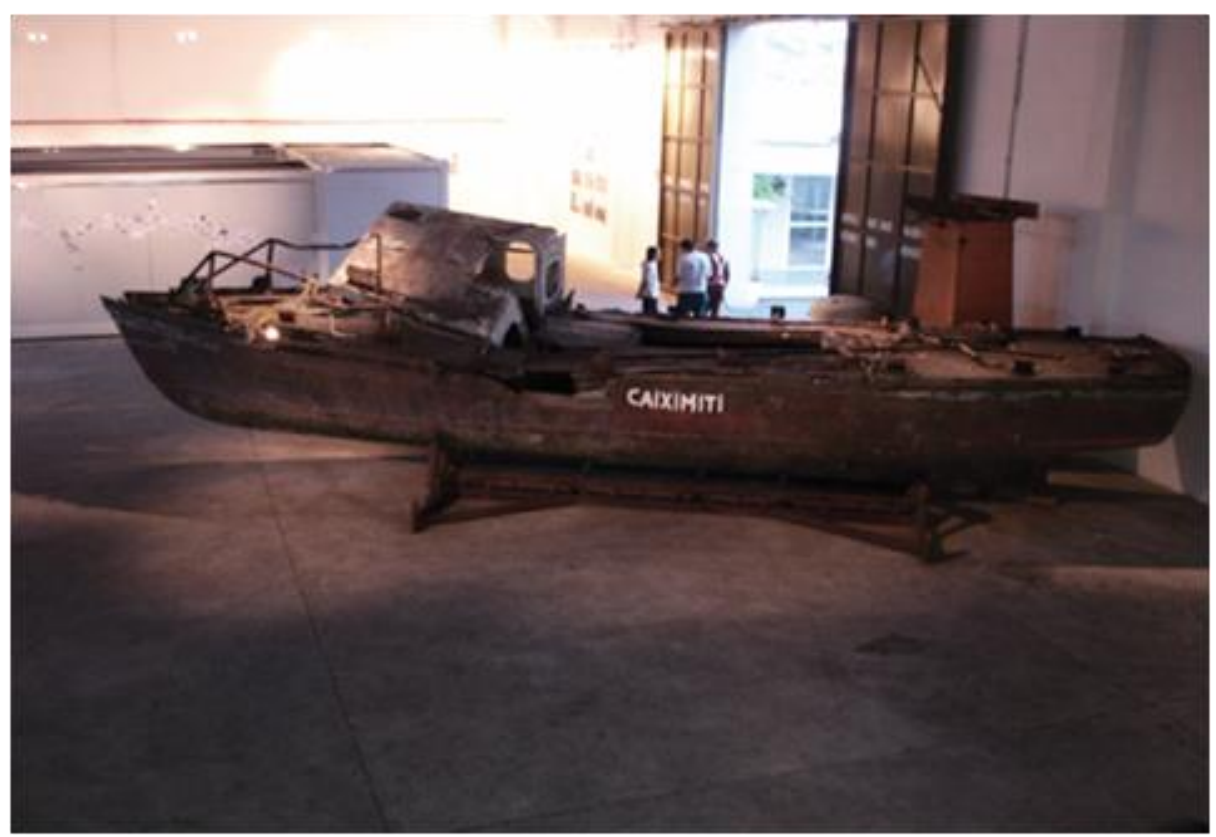

Fonte: Arquivo da autora (2006).

Outras propostas, ainda que em grau menos acentuado, também dialogaram com o espaço do evento. Beatriz Pimenta, em Navegar é preciso, viver não é preciso, por exemplo, inseriu lascas de parede branca sobre uma série de três fotografias de Christina Bocayuva, evocando os movimentos de 
contração e dilatação das rachaduras nas paredes do armazém portuário "carregadas de calor e umidade" (PIMENTA, 2006). Mas, a maior parte das obras apresentadas era autônoma em relação ao espaço e recorria, seguindo o edital, implícita ou explicitamente, ao mar como metáfora. Mar de Nomes de Edney Antunes; Mares Edificados de Fabio Okamoto; Livro Degelo: na tangente do Respiro do Mar de Gustavo Pessoa; Água Viva de Bruno Vieira; Ela não está a bordo? de Adams Carvalho; Deriva de Marcelo Salum; NAU SEA do coletivo LAB, Duas Margens (Pacífico) de Carla Zaccagnini, 16 px azuis de Maria Lúcia Cattani, Rede de Lâminas de Roosivelt Pinheiro, dentre outras, ilustram a assertiva.

No tocante à noção de participação, Ana Gastelois, em Pororoca 01 (Fig.19), informou no memorial que seu trabalho - um desenho-dança, construído pelo registro da medida máxima do braço para cima e para baixo "[...] formando uma espessa paisagem de horizontes prováveis", realizado diretamente na parede do armazém - era um jogo interativo que convidava "[...] o espectador a imprimir o seu gesto-limite-ritmo, no mesmo eixo, reativando, sobrepondo e recompondo o desenho" (GASTELOIS, 2006). Charles Klitzke, por sua vez, enviou reprografias de desenhos sobre papel adesivo com instruções de montagem. Seu desenho expandido possuía uma única especificação: a organicidade. Porém, essa aparente liberdade fornecida àquele que executasse a montagem implicava a compreensão do processo utilizado pelo artista em exposições anteriores. A ordem subjetiva guiada "[...] pelo humor, pelas horas, pelo dia em que o montador irá realizá-la" deveria seguir o modelo mostrado nas imagens enviadas, não podendo "[...] de modo algum ser de todo descaracterizado" (KLITZKE, 2006). Se, por um lado, a equação entre a autonomia do estado de espírito do montador e as regras impostas pelo artista são paradoxais, por outro lado, ela não é muito diversa do paradoxo que convida ao diálogo com o espaço, mas dentro das limitações impostas no edital - como, por exemplo, a cláusula que institui exclusividade da equipe de organização quanto à montagem. Tanto na proposta de Charles Klitzke quanto na de Ana Gastelois, a ideia de participação não poderia sair dos limites sugeridos pelos artistas. Se, no caso da segunda, a imposição era destinada aos visitantes, a proposta de Klitzke circunscrevia a participação à figura do montador.

Montagem e participação são duas questões que tiveram destino diverso ao aventado pela artista Raquel Baelles na sua proposta inicial. Intitulado de Língua - uma bobina de aço de 7 toneladas em parte desenrolada (Fig. 20) - o trabalho deveria terminar "lambendo" o mar, porém, a obra foi disposta apontando para o espaço interno do armazém (por restrições da CODESA), e a participação dos visitantes não foi prevista. Entretanto, sem os indicativos de limite de proximidade, muitos deles, sobretudo crianças, acabaram interagindo com a obra, pisando ou pulando sobre as partes mais elevadas que formava uma espécie de onda. A folha de aço que deveria ser corroída pelo 
sal marítimo como uma língua que, ao sentir o sabor do mar, iria contaminá-lo (BAELLES, 2006), teve sua superfície riscada pelos visitantes entusiasmados com os ruídos provocados ao pisoteá-la.

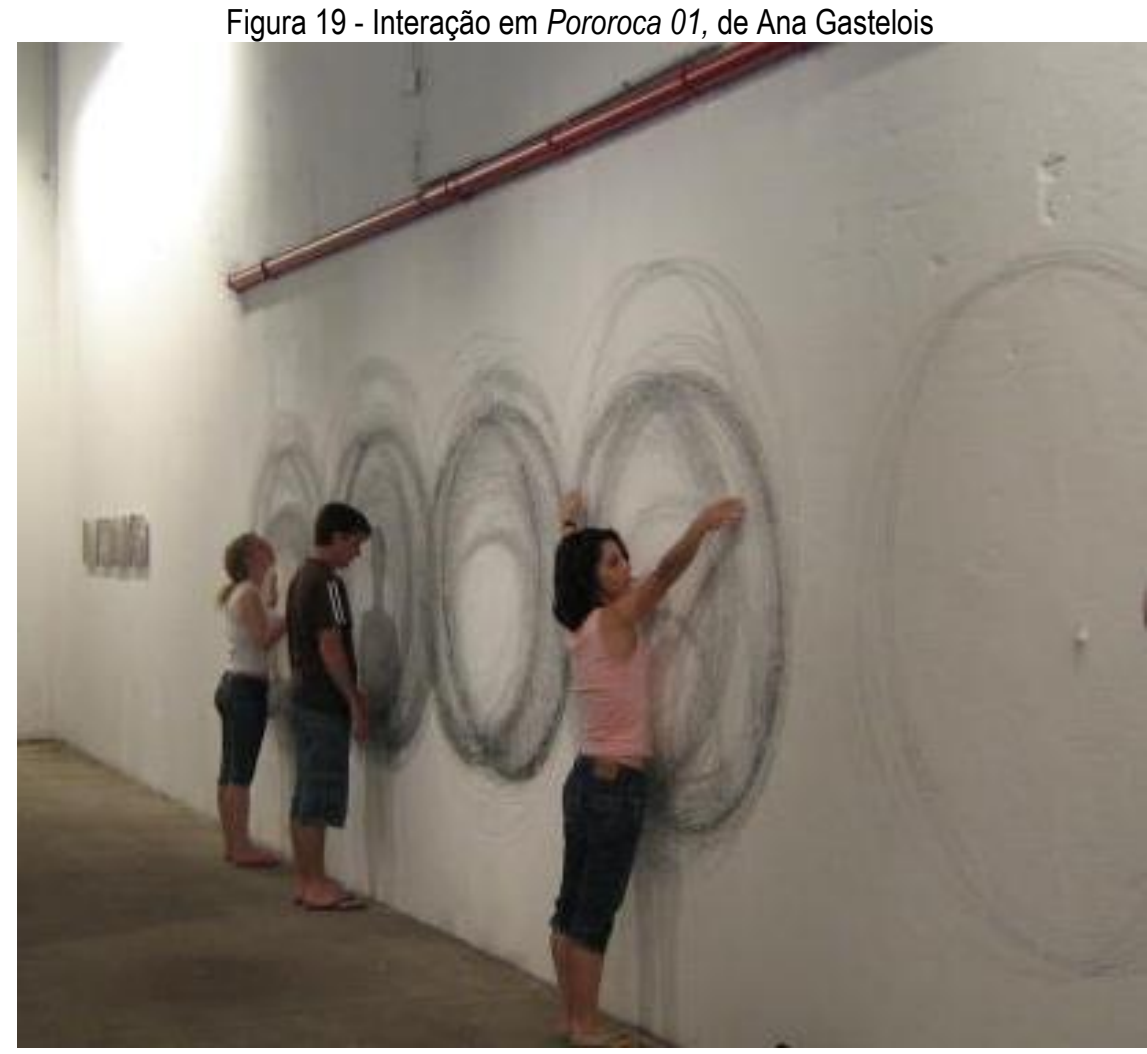

Fonte: Ação Educativa do $7^{0}$ Salão do Mar (2006).

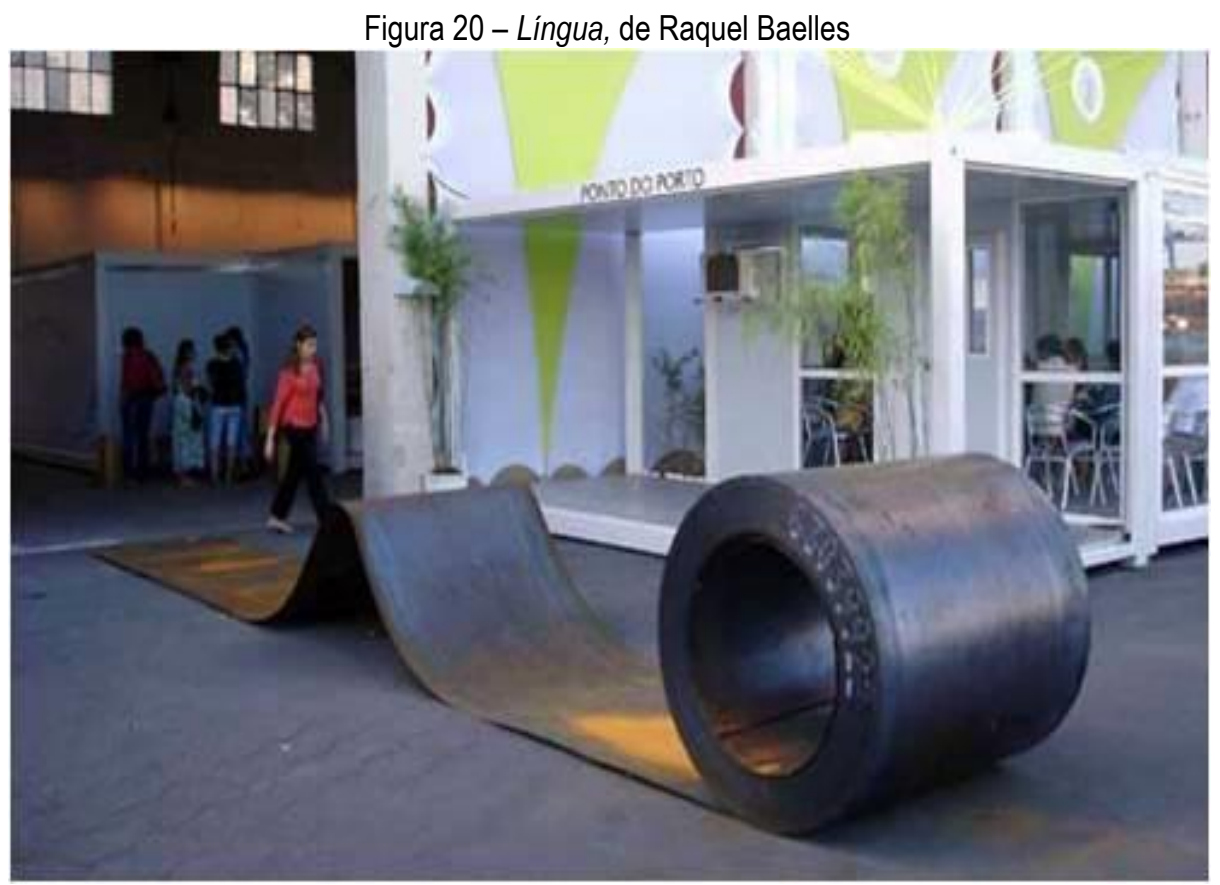

Fonte: Ação Educativa do $7^{0}$ Salão do Mar (2006). 
Por sua vez, o acentuado interesse em dialogar com o tecido urbano, pode ser detectado mesmo nos trabalhos que utilizaram como referência o legado histórico das pinturas de paisagem. Nestes, o mar é evocado e relacionado com problemáticas próprias às cidades. Na obra Horizonte recortado, para localidades não-litorâneas de Miro Soares, a proposta foi "[...] realizar um deslocamento do horizonte da marinha para o interior do espaço expositivo" (Fig. 21). Tal deslocamento aventava ainda preencher uma lacuna nas grandes cidades que não são contempladas com a "[...] linha do horizonte que se forma sobre o mar" considerando "[...] a infinidade de prédios e arranha-céus" (SOARES, 2006)266 que impedem sua visualização. Patrícia Osses, em Mar de Gropius, Cristine de Bem e Canto, com Malecon, e Camila Sposati, na obra Fumaça de Resgate (Vitória) (Fig. 22), de maneiras diferenciadas também evocam o repertório da pintura de paisagem, reinterpretando-o sob a referência de cidades diversas: Berlim (Mar de Gropius), Havana (Malecon) e Vitória (Fumaça de Resgate). Os artistas Anníbal e Branca, em Leda e o Mar, explicitaram na proposta encaminhada ao Salão a importância da história da arte na discussão que propunham, em uma relação "[...] dialética entre 0 antigo e o novo, entre os conceitos da arte já firmados e os paradigmas do pensamento atual" (ANNÍBAL; BRANCA, 2006).

A noção da paisagem tropical na sua exuberância que, por meio dos relatos dos viajantes estrangeiros, entre os quais Saint-Hilaire ${ }^{267}$, contribuíram para fixar o modelo de cidade-natureza sintetizado na imagem do Rio de Janeiro, foi evocada no vídeo criado por Botner e Pedro denominado de Mar Aberto. Neste, a paisagem ainda resguarda o mesmo deslumbre das descrições tradicionais, bem como, a horizontalidade como referencial na representação pictórica - "[...] o vídeo foi criado em formato (16x9), para acentuar o formato horizontal da paisagem" (BOTNER; PEDRO, 2006) -, entretanto, é na relação entre paisagem e figura humana que a dupla se detém. Sobre esta questão, Bernard Lamblin (1983) 268 observou que, tanto nos quadros holandeses quanto nas paisagens impressionistas, a figura humana não tinha grande importância, sendo uma espécie de complemento da paisagem. Diminutas, nessas pinturas as personagens aparecem predominantemente exercendo alguma atividade (1983, p.369), "[...] essas figuras geralmente não são os autores de um drama, nem

\footnotetext{
266 Os trechos foram retirados do projeto enviado ao $7^{\circ}$ Salão do Mar pelo artista. SOARES, Miro. Horizonte recortado, para localidades não-litorâneas [da série Deslocamentos Impossíveis], 2006.

267 Ao descrever a paisagem carioca, Saint-Hilaire afirmou: "Nada no mundo, talvez, haja de tão belo quanto os arredores do Rio de Janeiro [...]. Aqui, a vegetação nunca repousa, e em todos os meses do ano, bosques e campos estão ornados de flores. Florestas virgens, tão antigas quanto o mundo, ostentam sua majestade às portas da capital brasileira". SAINT-HILAIRE, Auguste. Segunda viagem ao Rio de Janeiro a Minas Gerais e São Paulo. Belo Horizonte: Ed. Itatiaia; São Paulo: EDUSP, 1974, p.14.

268 LAMBLIN, Bernard. Le paysage. In: Peinture et temps. Paris: Kincksieck, 1983, p.369.
} 
contribuem para situar temporalmente a cena"269, conforme salientou Lamblin. O verdadeiro sujeito dos quadros é o instante atmosférico (LAMBLIN, 1983, p.370). Em Mar Aberto, ao contrário, a figura humana assume o protagonismo da cena mesmo quando dela se ausenta. A paisagem exuberante é apenas uma imagem no televisor para ser contemplada pelo homem que se exercita em uma bicicleta ergométrica. Se no momento inicial, o vídeo mescla a cena do homem pedalando e assistindo sua própria imagem no televisor, posteriormente, ele aparece movimentando-se na orla marítima e, em seguida lentamente alçando o céu. Na medida em que sobe, sua figura se esvai até desaparecer. A bicicleta, porém, continua pedalando sozinha. Na sequência final, o mesmo cenário do início - uma sala branca -, porém, sem a figura humana, apenas 0 aparelho com os pedais em movimento, figuram na cena. Nesse vídeo-instalação, os artistas, ao trazerem para dentro do espaço expositivo os elementos que constavam nas imagens projetadas - a televisão e o suporte utilizados no vídeo assistidos pela figura que se exercita na sala fechada -, procuraram desconstruir qualquer expectativa ilusória da noção tradicional de representação.

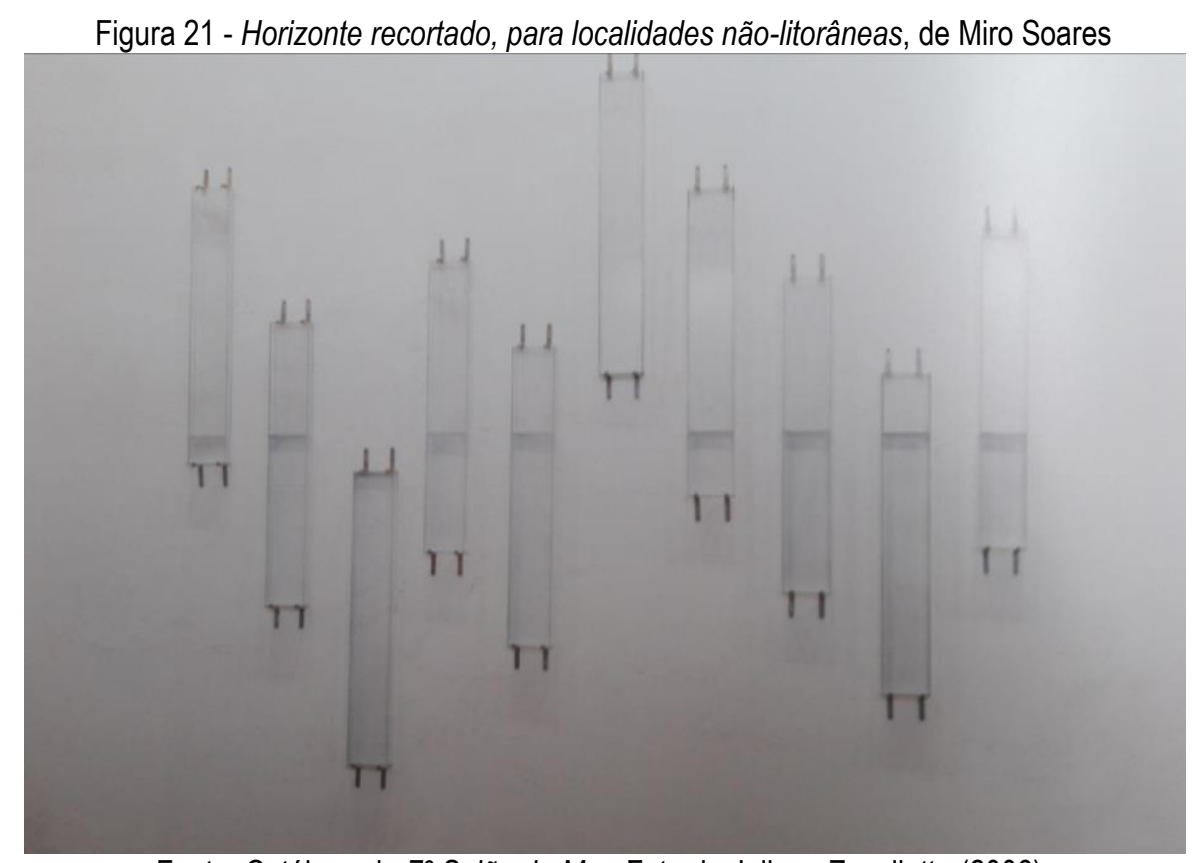

Fonte: Catálogo do $7^{0}$ Salão do Mar. Foto de Juliana Zucollotto (2006).

\footnotetext{
$269 \quad$ No trecho mencionado, Lamblin faz alusão à inclusão de trabalhadores nas pinturas de Salomon Ruysdael (16021670), exemplificando, o sentido atribuído à presença da figura humana no paisagismo tradicional, que teve origem na pintura de paisagem holandesa do século XVII.
} 
Figura 22 - Fumaça de Resgate, de Camila Sposati

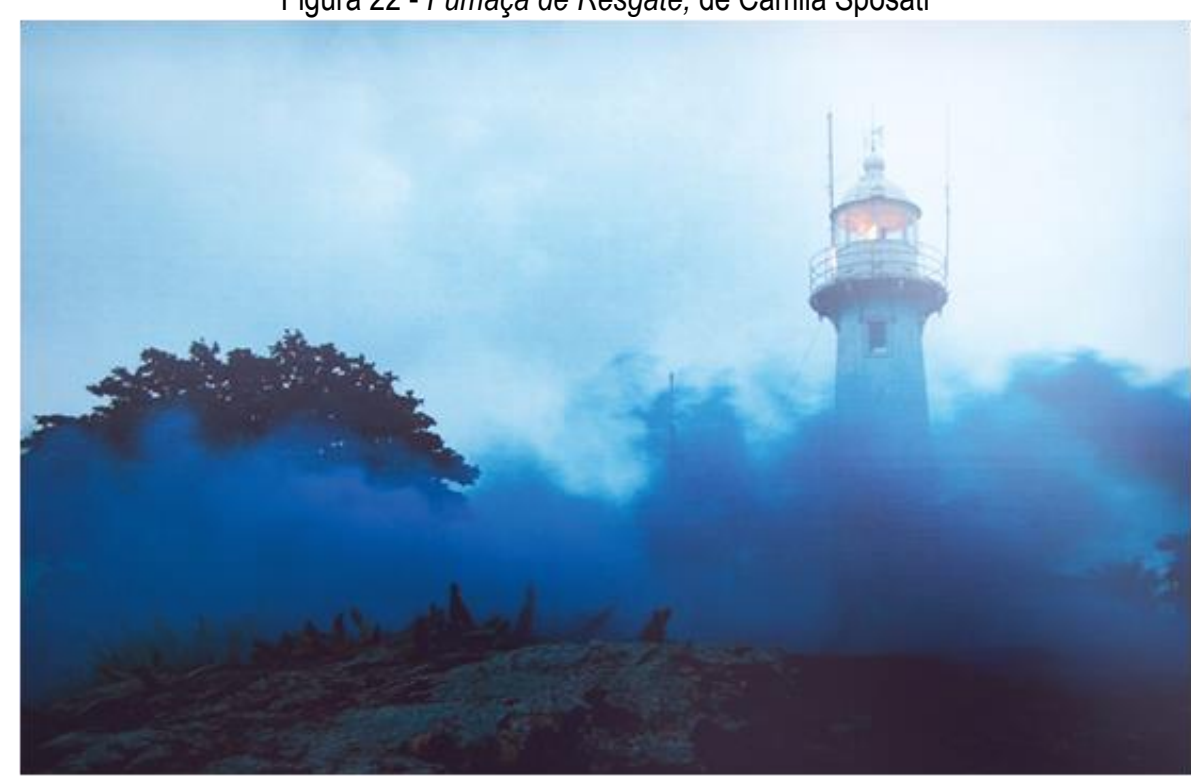

Fonte: Catálogo do $7^{0}$ Salão do Mar. Foto de Juliana Zucollotto (2006).

Herbert Pablo, em Banheirinho do Cais (Fig. 23), não recorreu ao legado tradicional da arte paisagística. A referência é também urbana, mas não à urbe em sentido macrossocial, mas em seu sentido cotidiano. Pablo parte de um cotidiano muito específico: o grafismo do imaginário homoerótico dos banheiros públicos masculinos. Espaço que o artista frequentava - conforme constou no seu memorial - transcrevendo junto aos registros deixados por outros usuários, algumas frases e desenhos, nos quais, predominam mensagens sexuais: "[...] papinho entre machos" (PABLO, 2006). Foi dos grafismos de um desses banheiros públicos, localizado próximo ao armazém portuário, "[...] zona de forte apelo erótico", que Herbert Pablo se apropriou e transpôs para o interior de um cubículo construído dentro do espaço expositivo, revestido com azulejos brancos. Canetas marcadoras foram deixadas para que os visitantes também inscrevessem o que Ihes aprouvessem. Diversamente do convite à interação proposto por Ana Gastelois, no qual o visitante deveria repetir o próprio gesto da artista, na superfície lisa do Banheirinho do Cais não foi estabelecido a priori o tipo de intervenção que poderia ser realizada. Entretanto, tal como nos banheiros públicos reais, as inscrições deixadas foram confidências íntimas, declarações de amor, xingamentos, propostas de sexo etc.. 270 Ainda que 0 artista não tenha lançado mão de outros sentidos, como o olfato, pelo odor acentuado tão característico desse tipo de espaço que invade e, normalmente, causa repulsa a maior parte dos transeuntes, a audição,

\footnotetext{
270 A afirmação teve como referência um breve exame de alguns estudos dedicados aos grafitos em banheiros, entre os quais: BARBOSA, Gustavo. Grafitos de banheiros. São Paulo: Brasiliense, 1984. ABUD, Cristiane de C. Ramos; ROSA, Maristela da. Diários íntimos: análise de escritos em banheiros públicos femininos de Florianópolis. Colóquio Internacional de História Cultural da Cidade. Porto Alegre: UFGS, 2015. Disponível em: <http://www.ufrgs.br/gthistoriaculturalrs/17SECristianecramosabudmaristeladarosa.pdf>. Acesso em: 12 set. 2017. Cabe ressaltar, que o primeiro estudo mencionado é um dos pioneiros no país, enquanto no outro, as autoras executaram uma revisão bibliográfica que serve de orientação para os interessados nessa temática.
} 
pelos murmúrios que constituem a esfera privada daqueles que os frequentam, ou o contato tátil, a mera simulação de laboratório desse lugar fora dos "dispositivos regulatórios" de vigilância e punição no sentido atribuído ao termo por Michel Foucault (2004) ${ }^{271}$-, incitou o público a replicar procedimentos semelhantes de transgressão. De certa forma, em Banheirinho do Cais, o artista efetuou uma operação diversa daquela tentativa de desmantelamento do caráter ilusório das imagens da arte como registro na cultura, presente no trabalho de Pedro e Botner. Herbert Pablo, conforme analisou Dária Jaremtchuk, relacionou '[...] uma linguagem considerada 'de segunda classe', apropriada de espaços públicos de eliminação de dejetos, para um outro, de fruição considerada 'elevada"' (JAREMTCHUK, 2006, p.23, grifo da autora). Entretanto, aspectos mais exclusivos do universo homoerótico dos banheiros públicos não foram partilhados. A partilha efetuada pelo artista (restrita aos elementos gráficos) ateve-se ao âmbito do conhecido ou do presumível. O caráter asséptico do espaço expositivo pode inibir, portanto, incursões mais acentuadas dentro da noção de real, revelando os limites de liberdade conferida às discussões no âmbito da arte, restritas muitas vezes à transposição apropriativa de linguagens, conforme sublinhou Dária Jaremtchuk.

É também do espaço urbano que André Burian retirou os elementos de sua poética. 0 artista apresentou uma série de três fotografias de cachorros atropelados e escreveu, sobre cada um dos cadáveres, Pirata, Tubarão e Sereia (Fig. 24). As imagens receberam molduras nas cores rosa, azul e amarelo. Entre o repúdio aos corpos de animais mortos, e os nomes e os pigmentos coloridos próprios do universo infantil, as fotos provocam desconforto: cadáveres em decomposição podem ser lúdicos? A operação efetuada por Burian sugere uma inversão na estratégia da obra Banheirinho do Cais, de Herbert Pablo. Ambos tomam como referência questões que, para o conforto de alguns, devem permanecer invisíveis, porém, entre os recursos de cunho pueril na apresentação das fotos de Burian e os utilizados por Herbert Pablo, há um sutil deslocamento quanto à noção de assepsia: ela é crítica, na obra de Burian, e ilusão de transgressão, na de Pablo.

\footnotetext{
271 Em Vigiar e Punir, o autor apresentou a vigilância e a punição como dois fatores que operam como "dispositivos" para o exercício do poder na sociedade. A vigilância, analisada a partir da existência do poder vigilante das prisões, é uma forma de controle "sem necessidade de armas, violência física, coações materiais. Apenas um olhar. Um olhar que vigia e que cada um, sentindo-o pesar sobre si, acabará por interiorizar" (2004, p.218). Enquanto a punição, analisada a partir das alterações históricas da legislação penal e seus métodos, podem abarcar desde a violência física até instituições correcionais. Expostos como indispensáveis para corrigir os infratores da ordem e da lei, a aplicação de penas torna-se, segundo 0 autor, um procedimento burocrático. FOUCAULT, Michel. Vigiar e punir. Tradução de Raquel Ramalhete. 29 ed. Petrópolis (RJ): Vozes, 2004.
} 
Figura 23 - Banheirinho do Cais, de Herbert Pablo

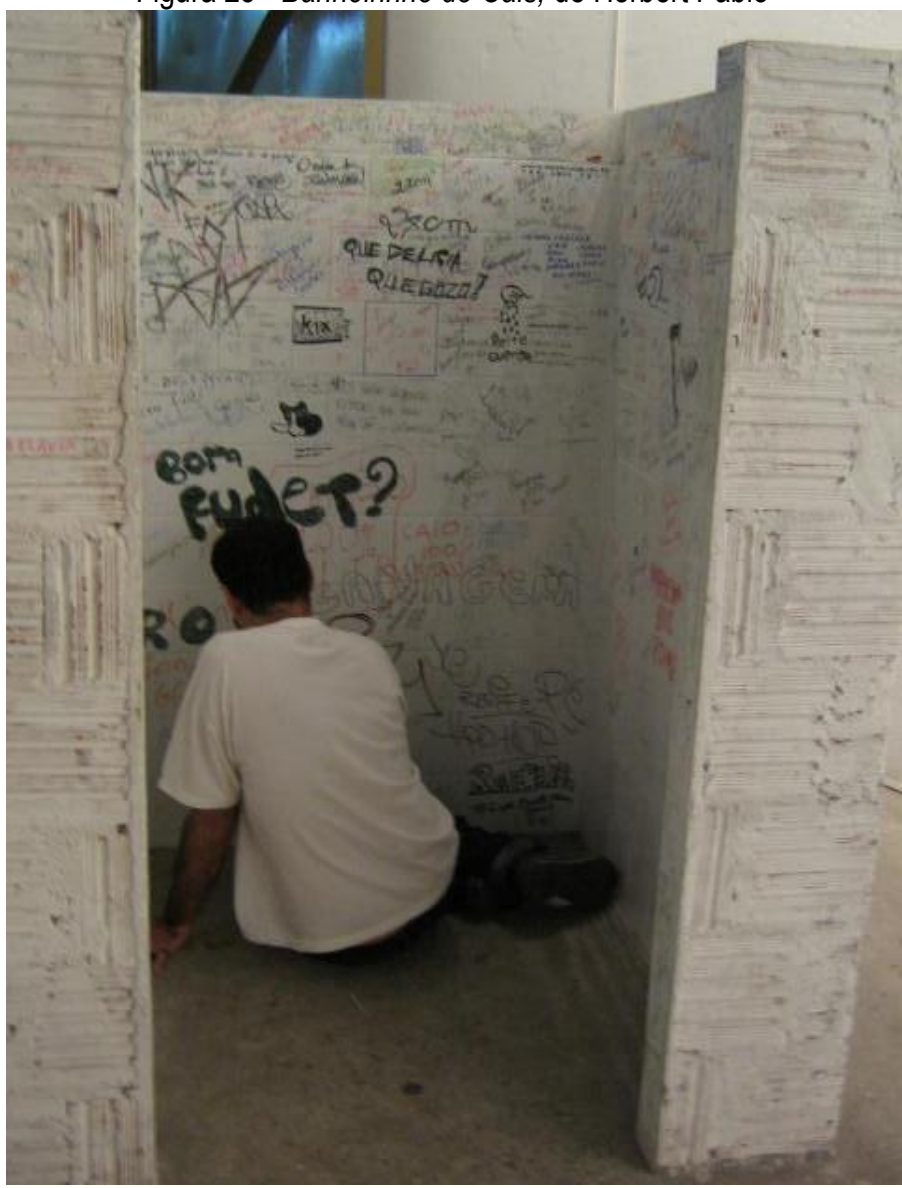

Fonte: Ação Educativa do $7^{\circ}$ Salão do Mar (2006).

Figura 24 - Pirata, Tubarão e Sereia, de André Burian

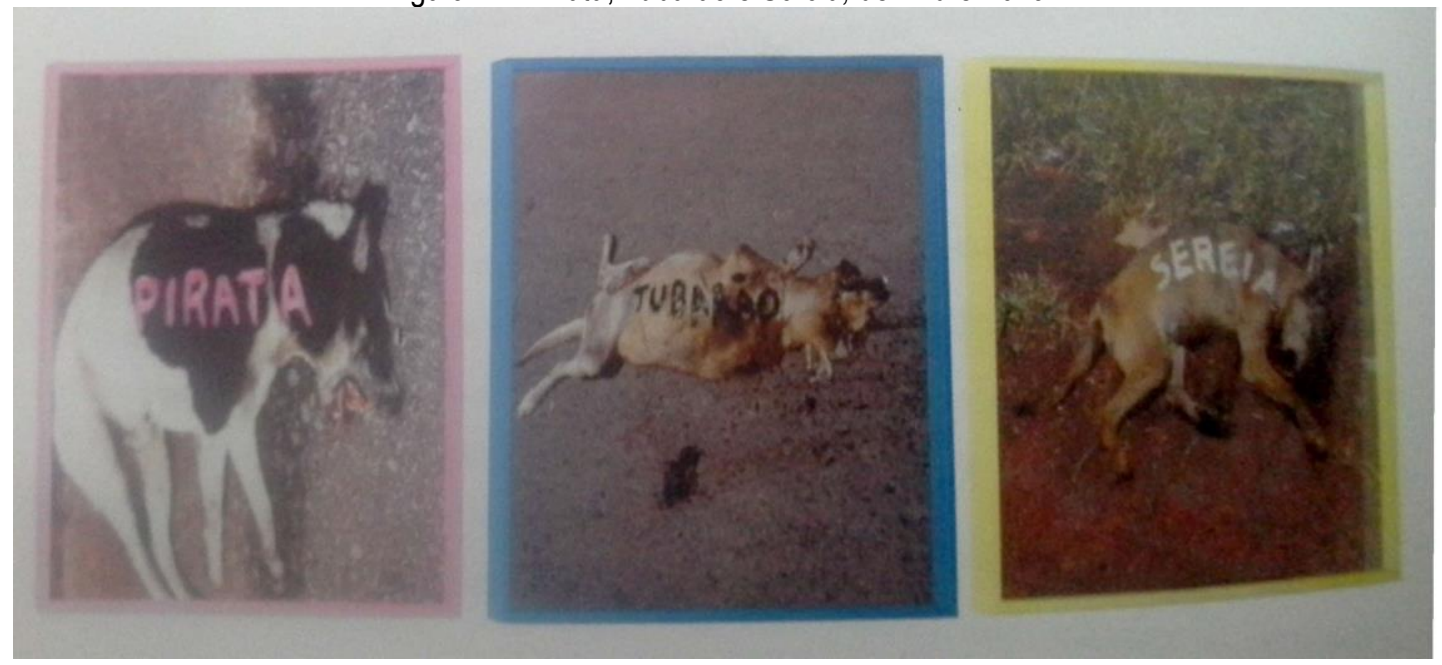

Fonte: Catálogo do $7^{0}$ Salão do Mar. Foto de Juliana Zucollotto (2006).

Como Herbert Pablo e André Burian, Lourival Cuquinha, com sua obra Varal, também abordou os avessos da noção de cidade como cenário, propondo uma intervenção urbana em um Salão que, 
apesar de afirmar no seu regulamento aceitar inscrições em todos os campos das artes visuais, não tinha previsto esse tipo de ação272. Sua intervenção, em parte disposta dentro do espaço expositivo (Fig. 25), mas em comunicação com o espaço urbano (possibilidade não explicitada no regulamento) é um ponto que merece ser sublinhado por explorar brechas possíveis nos ditames regulatórios. Diferente de outros artistas selecionados que apresentaram registros em vídeo de suas intervenções urbanas (como, por exemplo, Bruno Vieira com Água Viva ou Gustavo Pessoa com Livro Degelo: na Tangente do Respiro do Mar), Lourival Cuquinha não se ateve a apresentar uma ação anterior em outro formato. Um dos itens do edital poderia ter inibido o artista: "Só serão aceitas inscrições de obras inéditas e produzidas a partir de 2005". Ressalta-se que Varal foi apresentado pela primeira vez em 2003 no SPA das artes e nos anos seguintes em outras cidades brasileiras e no exterior. Evidentemente, em cada nova montagem a obra adquire outros significados, e a noção de ineditismo imposta no edital já era anacrônica. Entretanto, que garantia tinha Lourival Cuquinha de que a Comissão de Seleção interpretaria dessa forma? Dentre os itens obrigatórios para a inscrição constava um memorial descritivo do trabalho proposto. O memorial desse artista, diversamente de todos os outros, foi redigido com letras desenhadas com canetas coloridas (e, salvo engano, em uma folha pautada de um caderno escolar), fugindo da convenção tácita de uma apresentação mais formal.

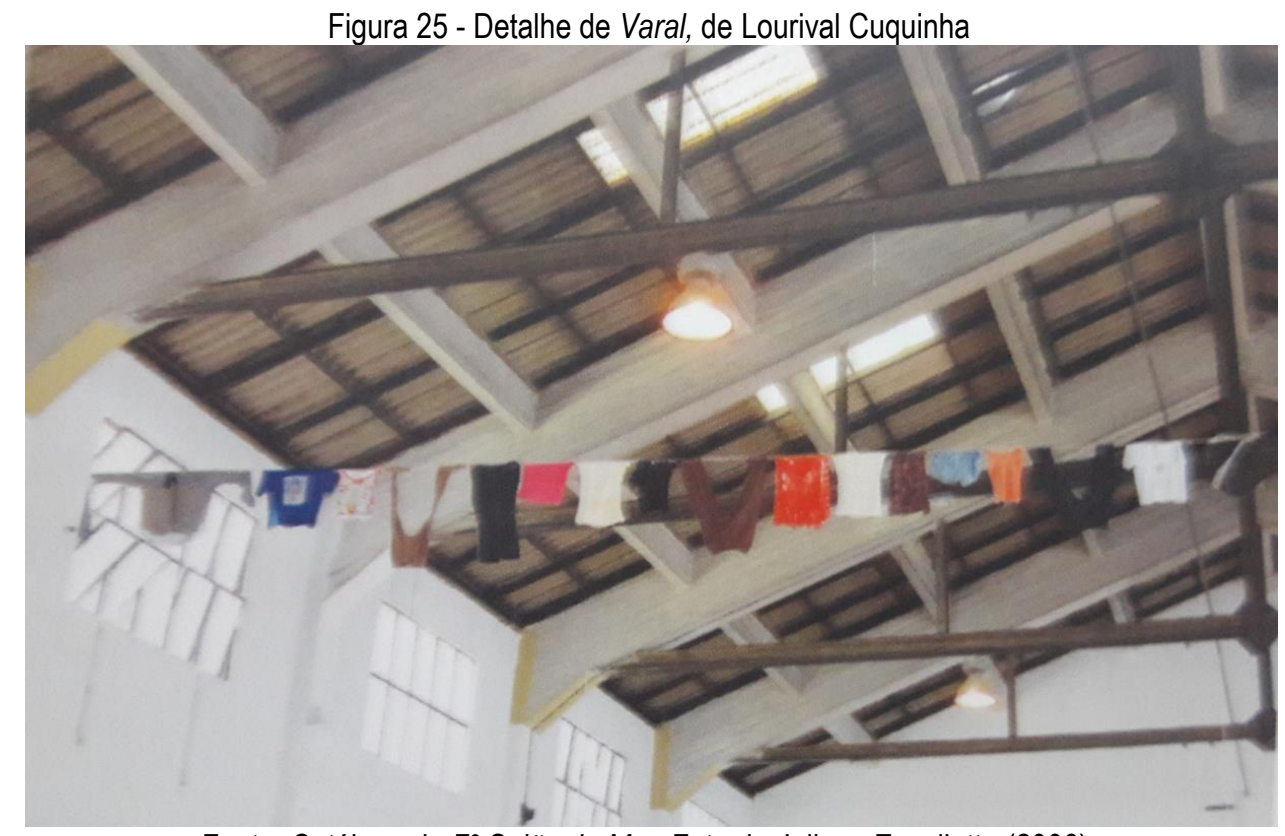

Fonte: Catálogo do $7^{\circ}$ Salão do Mar. Foto de Juliana Zucollotto (2006).

Porém, não são as normas ou convenções dos editais dos salões os aspectos mais relevantes discutidos pelo artista, elas apenas auxiliam a compor um quadro maior dentro da discussão por ele

272 Na ficha de inscrição era possível assinalar algumas categorias mais tradicionais (desenho, pintura, objeto, fotografia, vídeo-instalação, performance, gravura, escultura, instalação, videoarte) ou a opção outros. 
apresentada. O impacto visual do Varal, conforme analisou Raíza Ribeiro Cavalcanti (2016) ${ }^{273}$, exacerba o incômodo causado pelos moradores de uma área periférica do Recife que, por falta de espaço nas residências, invadem as vias urbanas, expondo suas roupas no espaço público. $\mathrm{Na}$ transposição proposta pelo artista, a ação corriqueira desses sujeitos invisíveis que reclamam por espaço, desenterra outros sujeitos apagados, anônimos e "[...] apartados da cidade, colocando-os no centro da mesma e a vista de todos. É uma revelação, para a cidade, do que ela preferia esquecer" (CAVALCANTI, 2016, p.136).

Para realizar esse trabalho no $7^{\circ}$ Salão do Mar, como em outros locais, Lourival Cuquinha necessitava que moradores de Vitória doassem roupas para a confecção do Varal. Foi preciso ainda, acionar o Corpo de Bombeiros para auxiliar na montagem, além de obter a permissão do proprietário do imóvel situado no lado oposto da avenida. Nas duas ações, em grau menos ou mais acentuado, sem 0 intermédio institucional, empecilhos diversos poderiam ter comprometido a concretização da obra, relegando-a à condição de projeto. Se para a obtenção das roupas, a colaboração de artistas locais foi significativa, o acionamento do Corpo de Bombeiros e o consentimento para utilizar o outro prédio, foram ações exequíveis em razão das solicitações terem sido acionadas por um órgão oficial. Sem a interferência institucional, duas outras obras dificilmente seriam executadas: Caximiti, de Isadora Bonder, e a obra Língua ${ }^{274}$, proposta por Raquel Baelles e já comentada. Dentre outros fatores, nesses dois casos, o uso de guindastes foi imprescindível para a inserção do barco e da bobina de aço no interior do espaço expositivo. Naturalmente, quando a instituição sublinha no regulamento a exclusividade no conceito de montagem, fica subentendida sua responsabilidade para a concretização das obras selecionadas. Entretanto, outro tópico do regulamento especifica que no caso de "obras não convencionais", montagem, operacionalização, preservação, manutenção e desmontagem são de inteira responsabilidade do artista. Cabe ressaltar que obras não convencionais no regulamento do $7^{\circ}$ Salão do Mar são aquelas que poderiam ser inscritas no item outros (como a intervenção urbana Varal).

As alterações na $8^{a}$ edição do evento (que serão analisadas no capítulo seguinte) foram desdobramentos de enunciações presentes no $7^{\circ}$ Salão do Mar. Destacou-se, nas obras comentadas, como elas se inseriram no discurso sobre a participação do público, sobre a inserção no espaço e sobre os agentes envolvidos no campo artístico. Vale ressaltar o notório interesse em dialogar com 0

273 CAVALCANTI, Raíza Ribeiro. Agenciamentos artísticos: uma análise sociológica sobre a ação dos trabalhos artísticos no interior do campo da arte brasileiro. 2016. Tese (Doutorado em Sociologia) - Universidade Federal de Pernambuco. Recife, 2016.

$274 \quad$ A bobina de aço, segundo informou a artista em e-mail encaminhado à instituição, pesava $5.960 \mathrm{~kg}$. 
tecido urbano em torno, e com as problemáticas próprias às cidades. 0 interesse acentuado pelo espaço urbano apresentado em diversos trabalhos, o caráter participativo e colaborativo evocado em outros, adquirem contornos diversos, mediante a proposta apresentada no $8^{\circ}$ Salão Bienal do Mar, que foi dedicada às práticas artísticas que estabelecessem uma relação interdisciplinar com a cidade, seus espaços e habitantes.

As tensões políticas presentes em macro e micro disputas, no $7^{0}$ Salão do Mar, foram amplificadas ou adquiriram outros contornos na edição seguinte do evento. Em relação à $7^{\mathrm{a}}$ mostra, é possível afirmar que, no plano macro, por meio do caráter espetacular do evento, houve uma ampliação de sua visibilidade, tanto para os capixabas quanto para os outros Estados da Federação, reforçada pelo local de sua realização e pela variedade de atrações. Na mesma direção expansionista, a ação educativa despontou junto com a relevância dos números para o cenário artístico, no qual "democracia", "espetáculo" e "consumo" são termos interdependentes. O público, como massa reabilitada, protagonizou uma função de duas vias aparentemente contraditórias entre si, graças ao novo papel a ele concedido pelos patrocinadores da virada do milênio. A tendência à interatividade, aspecto primordial na virada do século - discurso comum e predominante, de modo quase equivalente, nos videogames e internet nas décadas de 1980 e 1990, respectivamente, como na abertura democrática em países como o Brasil em que cada indivíduo, independente da cor, gênero, classe social e escolaridade, "interferir" no futuro do país por meio do voto — não poderia ser ignorada por uma produção que pretendesse ser atualizada. O público é tanto aquele capaz de dar corpo a um governo, como a grande massa que interage com novo consumo de produtos diferenciados, entre elas também a cultura. O novo papel reservado ao público, tratado agora como consumidor de um produto fornecido pela cadeia produtora de arte, pode ser visto como motor para transformações nas estruturas das próprias instituições artísticas como a gratuidade, sazonalidade, interatividade e espetacularização. Este processo não significa, entretanto, que houve um desenvolvimento em direção ao protagonismo na participação do público, mas sim o uso de estratégias mercadológicas pelas instituições em prol da manutenção da audiência, ameaçada por tantos outros estímulos da vida urbana. O público, como nas eleições, nas lojas, nos televisores ou nos streamings, é em última instância, consumidor ${ }^{275}$.

No microuniverso da linguagem artística, tal qual no plano macro, a onda pós-modernista, pretensiosamente horizontal diante da verticalidade modernista, redirecionou a relação entre obra e leitor, minimizando-o a priori em linguagens que incitam a participação, a experiência, e exaltam o processo inacabado. É sintomático, entretanto, que as formas de exibição escolhidas pelos

275 Vale lembrar que a partir da década de 1980 entrou em ascensão à visibilidade a figura do marqueteiro político. 
participantes do $7^{\circ}$ Salão do Mar retomem dispositivos clássicos, como a linguagem da pintura de paisagem, ou adaptem à moldura da arte temas inquietantes a eles, como a representação de experiências ou tragédias, em micronarrativas pessoais. Em ambos os casos, entretanto, os limites são dados pelo pudor e pela autoridade impostos de forma disciplinar e, consequentemente, pelo espaço. Tal como a estrutura democrática macro, as tentativas de dissolução da hierarquia estética parecem camuflagens que permitem a perpetuação das antigas autoridades. 


\section{CAPÍTULO 3}

\section{TRANSBORDAMENTOS E DEMARCAÇÕES}

Digo: o real não está na saída nem na chegada: ele se dispõe para a gente é no meio da travessia [...].

Aquela travessia durou só um instantezinho enorme (ROSA, 1994, p.558).

Resquícios de Caminho das águas (Fig. 26), uma extensa e discreta linha azul pintada no chão da região central de Vitória (ES), projeto do artista Piatan Lube para o $8^{\circ}$ Salão Bienal do Mar: ondas, pontes e intervenções navegáveis, organizado pela Casa Porto das Artes Plásticas entre 20 de dezembro de 2008 até 05 de fevereiro de 2009, ainda hoje (2018) podem ser encontrados na cidade. A intervenção foi refeita em duas ocasiões - em 2010 e 2014276 —, assim outras camadas de tinta foram aglutinadas ao primeiro traçado de 30 centímetros de largura e aproximadamente 1.800 metros de extensão, que tinha início em uma área próxima ao Porto de Vitória e terminava em um prosaico banco de rua instalado em uma parte mais elevada da ilha, entre o Morro do Forte São João e o Penedo277, pouco antes da Avenida Vitória se bifurcar nas duas das principais artérias 278 que perpassam o Centro histórico da capital do Espírito Santo, procurando demarcar o limite entre mar e terra, anterior aos aterros que alteraram o contorno natural da ilha. $O$ banco parecia convidar 0 eventual transeunte raro nesse trecho da cidade - para uma pausa reflexiva, entre os ruídos provocados pela movimentação frenética dos automóveis que transitam no local, a cenográfica paisagem da entrada da Baía de Vitória e os antigos limites entre o mar e a terra que foram aterrados para a expansão do Centro da cidade (Fig. 26).

276 Em 2009, o artista teve seu projeto aprovado no Edital Arte Patrimônio, lançado nacionalmente pelo Paço Imperial, em parceria com o Ministério da Cultura (MinC) e o Instituto do Patrimônio Histórico e Artístico Nacional (IPHAN). Nessa etapa, o projeto foi realizado em Florianópolis (SC), no final de 2009 e, em Vitória, em janeiro de 2010. Em 2014, a intervenção fez parte da mostra "Dos Salões do Mar à Bienal" organizada pela Casa Porto das Artes Plásticas na reabertura do espaço, após a conclusão das obras de restauro.

277 O Penedo, maciço rochoso localizado na entrada da Baía de Vitória, é um dos principais símbolos da cidade. Temendo sua desfiguração, a solicitação de tombamento foi feita pela Associação Capixaba de Proteção ao Meio Ambiente, durante as obras no Cais de Capuaba. Em 1983, com a finalização do processo, o Penedo tornou-se o primeiro monumento natural tombado do Espírito Santo. Disponível em: <http://www.secult.es.gov.br/patrimonios/naturais>. Acesso em: 10 ago. 2016.

278 Trata-se das avenidas Jerônimo Monteiro e Princesa Isabel. Ressalta-se que a Avenida Jerônimo Monteiro é antecedida, em um pequeno trecho, pela Rua Henrique de Novaes. 
Figura 26 - Imagem do projeto de Piatan Lube

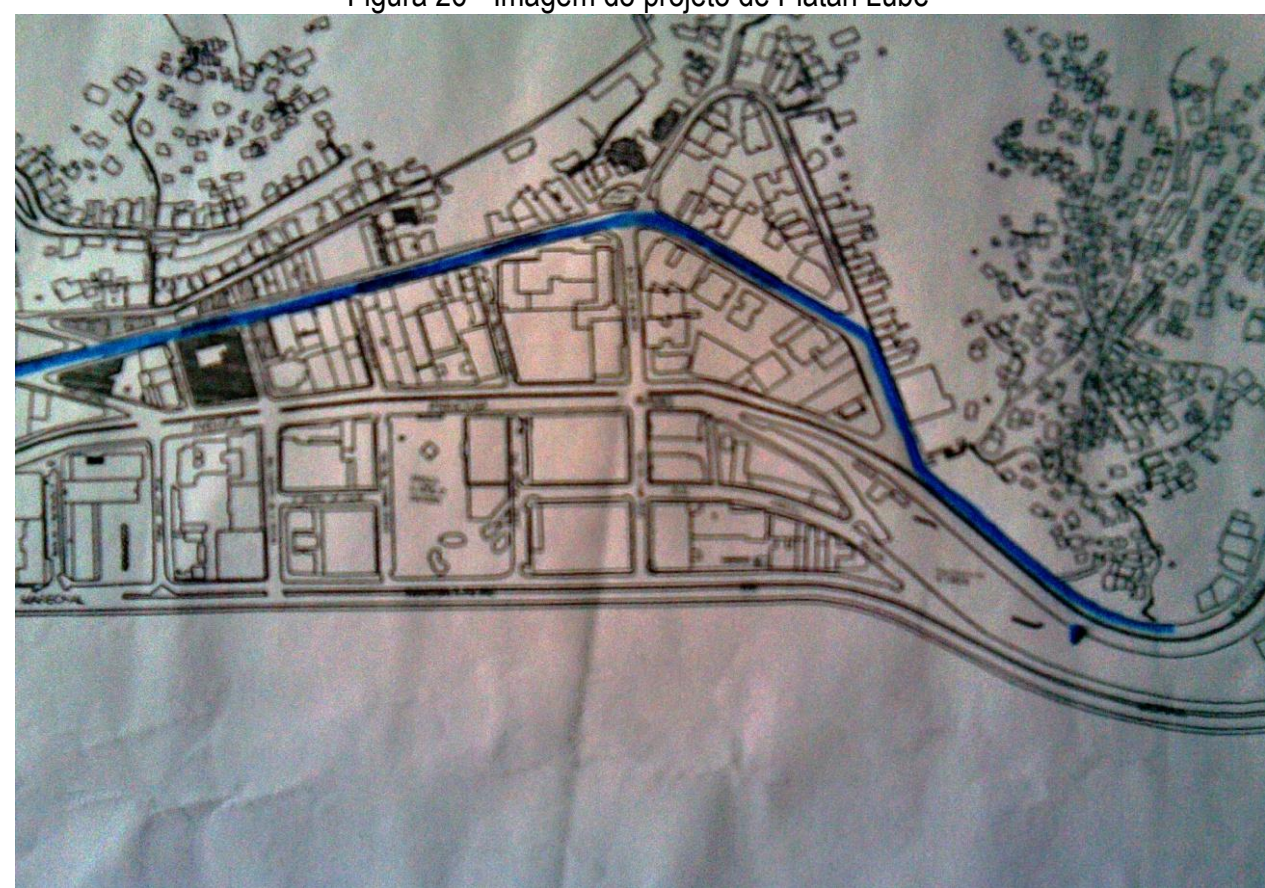

Fonte: Arquivo da autora (2008).

Com o tempo, entretanto, a linha perdeu sua uniformidade: alguns trechos foram desbotados pelo fluxo dos passantes, veículos, intempéries ou em função das ações provocadas pelos mecanismos de higienização do espaço público que procuram expulsar os resíduos continuamente gerados; outros pedaços foram soterrados ou retirados para dar lugar a calçadas novas e outras reconfigurações urbanas. Intercalando, porém, os vazios ou partes pálidas, restaram alguns fragmentos com a cor ainda viva, prorrogando, tantos anos depois, o que foi proposto como efêmero ou temporário no edital da mostra de 2008. Como escreveu o artista no seu projeto, a cidade é um "organismo vivo", assim, a durabilidade da intervenção não era prerrogativa dele ou da instituição promotora, dependeria antes de um conjunto de fatores circunstanciais que seriam encarregados da "efemeridade da obra interventiva"279. Nas palavras do artista, no memorial do projeto:

O caráter efêmero existe à medida que a cidade continuará sendo um organismo vivo, ou seja, o fluxo de pessoas, de automóveis, de bicicletas, de sujeiras... Encarregar-se-á desta possibilidade enquanto a efemeridade da obra interventiva (LUBE, 2008).

279 Ressalta-se ainda que, no memorial o item referente ao "sistema de montagem", Piatan Lube afirmou que usaria tinta acrílica polivinílica (PVA) a base de água. A tinta, segundo o artista, quando exposta as intempéries temporais (chuva, sol, vento) e ao sistema de limpeza das ruas da cidade pelos caminhões pipa, contribuiria para a transitoriedade da intervenção. Arquivo da autora. A quem possa interessar a instituição promotora, a Casa Porto das Artes Plásticas, possui 0 original impresso no seu arquivo documental. 


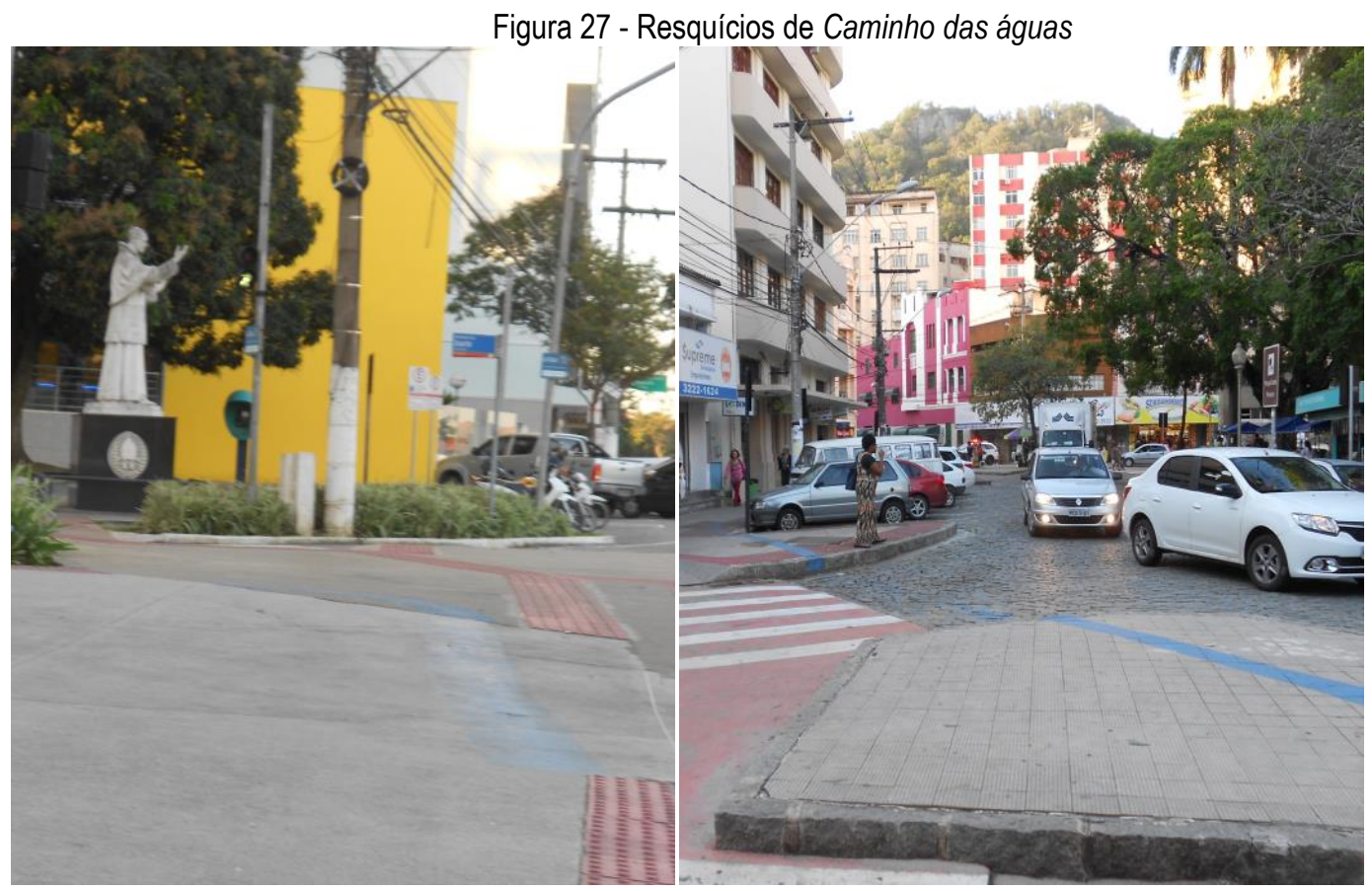

Fonte: Fotos da autora (2018).

A intervenção Caminho das águas foi um dos 12 (doze) projetos selecionados no edital do $8^{\circ}$ Salão Bienal do Mar, sendo hoje e, por fatores circunstanciais, o único vestígio visual relativo ao evento que permaneceu na cidade. Igualmente por fatores circunstanciais outra obra que fazia parte da mostra teve destino diverso ao que foi previsto. Trata-se do trabalho Você vê? (Figs. 28 e 29) concebido pelo arquiteto-urbanista e artista francês Jean-Blaise Picheral que integrou a mostra na condição de "artista convidado"280, sendo essa a única obra do evento que possuía o intuito de ser permanente. Com aproximadamente 15 (quinze) metros de altura, o trabalho era formado por três hastes finas de metal que foram parafusadas em um trecho cimentado entre o mar e o muro do calçadão, unindo-se em uma forma triangular, ao centro da qual, foi disposta uma boia de sinalização náutica alaranjada. Com a mesma coloração da boia, uma pequena bandeira foi hasteada na ponta de uma vara de caniço fixada em um dos três tubos de aço. Esta obra fixa deveria ser complementada com uma instalação flutuante que 0 artista declarou pretender realizar em ocasião futura (PICHERAL, 2008, p.103).

280 É necessário esclarecer que o autor do trabalho, Jean-Blaise Picheral, em virtude de uma parceria entre as cidades de Dunkerque (França) e Vitória (ES/Brasil), passou a visitar a trabalho a Capital do Espírito Santo. O motivo de sua participação no evento pode ser vislumbrado na declaração da então Coordenadora da Casa Porto das Artes Plásticas, Maria Helena Lindenberg, que consta em um texto informativo da Secretaria Municipal de Cultura da Prefeitura de Vitória: "[...] em 2006, ele conheceu a Bienal do Mar e praticamente se 'convidou' para participar da próxima edição." Em virtude da situação embaraçosa que envolveu sua participação no evento, em tom defensivo, o artista inicia seu texto no catálogo do evento, informando que foi convidado pelos organizadores. Os membros da Comissão responsável pelo convite foram: José Cirillo, Maria Helena Lindenberg, Nenna e Neusa Mendes. SAMORA, Loureta. Salão Bienal do Mar terá trabalho de artista plástico francês. Disponível em: <http://legado.vitoria.es.gov.br/diario/2008/1212/mar.asp>. Acesso em: 10 ago. 2016. 
O trabalho foi instalado na Avenida Marechal Mascarenhas de Moraes (Avenida Beira-Mar), em um ponto perto do antigo Terminal Aquaviário Dom Bosco, nas proximidades da PMV. A construção esquálida tinha como pano de fundo um dos principais marcos paisagísticos do Espírito Santo: 0 Penedo - um maciço rochoso com aproximadamente 133 metros acima do nível do mar - localizado na entrada da Baía de Vitória. Segundo o artista:

[...] eu quis dialogar e não lutar contra o Penedo tão característico da paisagem da cidade e do porto: dialogar com os meios mais tênues, mais ligeiros: tubos de aço com o menor diâmetro possível, caniço, boia de um laranja vivo (PICHERAL, 2009, p.103, grifo meu).

Figura 28 - Montagem da obra Você vê?

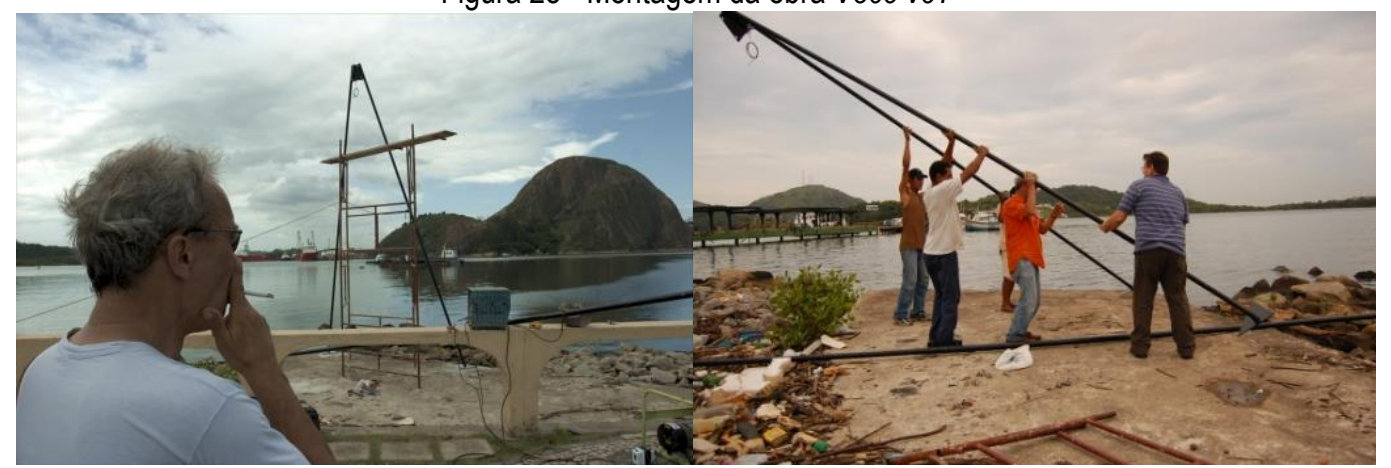

Fonte: Arquivo da autora. Foto: Gibran Chequer (2008).

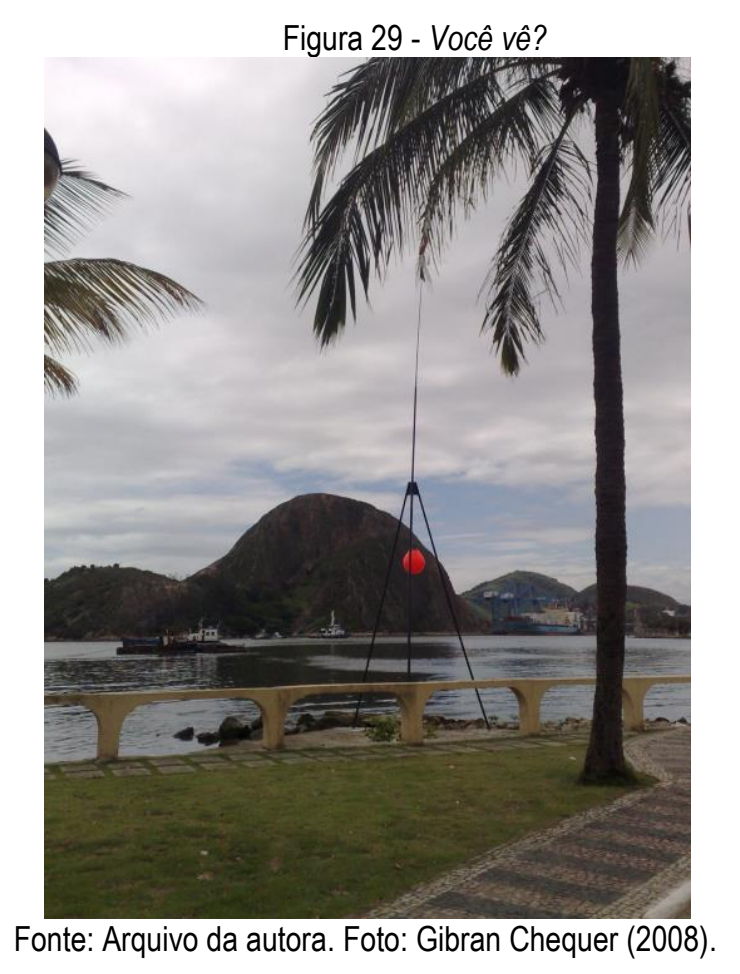

A condescendência retórica do artista, sua suposta benevolência com a magnitude do monumento natural pode ser aproximada da declarada em relação aos frequentadores do espaço 
público: "[...] pessoas que, geralmente, não encontramos nos lugares da arte [museus, galerias...]" (PICHERAL, 2009, p.103), segundo ele, não é "[...] tanto a obra em si que me interessa, mas o olhar novo que ela possa provocar no ambiente em que se insere" (2009, p.103, grifo meu). Em ambos os casos é possível detectar algumas presunções características no discurso artístico do período, com a intensificação da inserção da arte no espaço urbano, muitas vezes oscilando entre questões associadas à tradição e o desejo de superá-la: por um lado, a tentativa de amenizar a ambição de alçar posição de destaque em meio às inúmeras interferências das cidades - que nesse caso é sublinhada na relação entre a obra e a paisagem natural -; por outro, e por extensão, a crença ou o desejo que a discussão proposta pelo trabalho provocasse ruídos na rotina do transeunte, remetendo a uma noção tributária da segunda metade do século XIX, personificada na figura do flâneur e errâncias urbanas posteriores, como as deambulações das ações dos dadaístas e surrealistas, no começo do século XX, e as derivas urbanas dos situacionistas, na segunda metade do século XX281.

Dialogar e provocar foram ações almejadas por Jean-Blaise Picheral, diametralmente diversas da possibilidade mais evidente de seu trabalho ser apenas mais um dos inúmeros estímulos presentes na cidade clamando por visibilidade. Apesar da intenção de longevidade, esboçada na inclusão da obra na categoria de permanente e inversamente ao que sugere seu título Você vê? já não pode mais ser visualizada na cidade. Não foi localizada qualquer notícia referente à sua retirada poucos anos depois de sua instalação282. Não seria precipitado, portanto, supor uma trajetória dilacerante para a obra: provavelmente, bandeira e boia - expostas às intempéries e sem as devidas substituições deixaram de criar contraste com o tom escuro do metal; talvez tenham caído ou descolorido, restando apenas os tubos de aço. Você vê?, como as demais obras do evento, recebeu uma placa de sinalização provisória confeccionada em madeira e revestida com um adesivo, no qual estavam impressos o nome do artista, sua procedência e título da obra, além da logomarca da mostra e seu período de realização. Certamente, a placa permaneceu pouco tempo no local, dificultando a identificação do trabalho tanto pelos transeuntes, quanto pelos agentes encarregados da manutenção do espaço urbano. É possível conjecturar ainda que os tubos de aço tenham sido furtados ${ }^{283}$, questão recorrente no cotidiano das cidades. Era para ser permanente, mas não o foi, assim como Caminhos

281 Em texto analítico sobre a espetacularização das cidades contemporâneas e a experiência física urbana enquanto prática cotidiana, estética e artística, Paola Berenstein Jacques, remete aos três momentos históricos acima mencionadosassociando-os a exemplos brasileiros, como os escritos de João do Rio, as Experiências de Flávio de Carvalho e aos trabalhos de Hélio Oiticica, Lygia Clark e Ligia Pape -, direcionando sua crítica à utilização espetacular e não participativa que as novas tecnologias podem provocar. JACQUES, Paola Berenstein. Errâncias Urbanas: a arte de andar pela cidade. Arqtexto, Porto Alegre, v. 7, p.16-25, 2005.

$282 \quad$ Segundo relataram alguns moradores de Vitória, desde 2013, a obra já não estava mais no local.

283 A obra foi instalada próxima ao antigo Terminal Aquaviário Dom Bosco, que foi desativado no início dos anos de 2000, passando a servir de abrigo para usuários de drogas. Disponível em: <http://universo.ufes.br/blog/2016/04/aquaviarioo-fantasma-que-assombra-os-mares-vitoria/>. Acesso em: 16 ago. 2017. 
das águas não deveria ter sobrevivido além dos meses de realização da mostra e, no entanto, foi refeita em duas outras ocasiões e, ainda resiste, em uma espécie de morte lenta e agonizante.

O próprio evento de que essas obras fizeram parte não foi mais realizado: a oitava foi a última edição da mostra. Tal fato contraria as previsões otimistas, contidas tanto em textos informativos, quanto oficiais, que anunciavam que realizar a céu aberto intervenções na cidade seria um passo inicial que poderia conduzir a desdobramentos mais ousados: "Vitória já mostrou que acolhe iniciativas como essa e nos encoraja a investir, a incentivar ainda mais o processo de formação e produção de nossos artistas"284.

O $8^{\circ}$ Salão Bienal do Mar pode ser tomado como um momento expressivo na cidade de Vitória da tentativa de colocar em pauta, por meio de um evento de intervenção urbana promovido no âmbito da SEMC/PMV, discussões envolvendo arte e democracia, substituindo a noção de arte/objeto por projetos e ações. Os pontos principais, emulados do Madrid Abierto - intervenções urbanas de caráter efêmero ou temporário, interdisciplinaridade com a cidade, seus espaços e habitantes - compõe um conjunto que foi, paulatinamente, sendo padronizado na década de 1990 e, extensivamente utilizado, especialmente, na primeira década do século XXI. Por que o entusiasmo em creditar que ao espaço urbano um estatuto de local privilegiado para as discussões que pretendiam debater a noção de democracia no plano artístico? Por que o termo "efêmero" foi incorporado, praticamente, de forma unânime? As duas partes que compõem o presente capítulo pretendem traçar algumas possibilidades de reflexão para as indagações acima.

\footnotetext{
284 A frase acima encerra o texto de apresentação da mostra assinado pelo prefeito de Vitória, João Carlos Coser. Ver: RUFINONI, Priscila, MARGOTTO, Samira. $8^{\circ}$ Salão Bienal do Mar: ondas, pontes e intervenções navegáveis. Vitória: SEMC/PMV, 2009, p.7.
} 


\title{
PARTE [1]
}

\author{
LANÇAR-SE ÀS RUAS
}

\subsection{REVERBERAÇÕES: MODELO E TRANSPOSIÇÃO}

A partir das décadas finais do século XX indagar sobre a função social da arte adquiriu novo vigor. Intervenção, ocupação, interdisciplinaridade com a cidade, seus espaços e habitantes são questões clamadas para abordar as ocupações artísticas, predominantemente efêmeras, que operam em ruas e praças na expectativa de debater a complexidade do binômio que envolve os termos arte e cidade. Por um lado, a concentração de pessoas nos centros maiores, o crescimento do individualismo, as inovações nas tecnologias da informação, aliadas às alterações políticas, econômicas e nas relações de trabalho no mundo capitalista foram fatores indissociáveis dos questionamentos em torno do papel a ser desempenhado pela arte e pelos artistas dentro dessa nova conjuntura. Por outro, 0 acentuado processo de privatização do espaço urbano, as contradições entre questões éticas, morais e as imposições legais foram tópicos que impulsionaram um segmento considerável da produção artística contemporânea a abordar questões associadas aos ideais democráticos utilizando o espaço urbano como elemento potencializador desse debate.

Evocar tais pontos, já bastante sublinhados, não dá conta de pensar as nuances mais sutis de suas reverberações em uma capital periférica no Brasil, como é o caso de Vitória. Assim, torna-se necessário, em primeiro lugar, recuar ao contexto alinhavado anteriormente e recordar os motivos que impulsionaram as ações desenvolvidas pelos coletivos de artistas enfocados: o desejo de tomar parte nas discussões de sua época, travando contatos com outros artistas e iniciativas congêneres, desenvolvidas em centros urbanos de referência. Não foi muito diferente com o $8^{\circ}$ Salão Bienal do Mar. 0 evento institucional também tentou acertar o passo com seu tempo, recorrendo às diretrizes propostas pelo projeto Madrid Abierto, adaptadas às peculiaridades locais. Portanto, foi um projeto experimental no âmbito das ações desenvolvidas na SEMC/PMV (já ensaiadas na sua edição anterior), é como tal que ele deve ser analisado.

Esse acertar o passo incluiu incorporar a sua nomenclatura à periodicidade do evento. Evidentemente, mais do que simplesmente informar sobre o período de realização, a utilização do termo bienal tentava salientar seu caráter contemporâneo. Porém, a manutenção do termo salão e os 
anacronismos a ele associados, também indicava os limites na abordagem que desejava ser nova. Tais limites foram expressos no texto da SEMC/PMV que, parafraseando Rosalind Krauss, afirmou que $08^{\circ}$ Salão Bienal do Mar almejava ser um "'Salão no campo ampliado', rompendo com as paredes, com as salas, ganhando os espaços públicos, expondo-se à observação ativa dos passantes" (In: RUFINONI, MARGOTTO, 2009b, p.10).

O $8^{\circ}$ Salão Bienal do Mar procurou implementar e ampliar dispositivos ligados aos debates sobre democracia que já transpareciam no $7^{\circ}$ Salão do Mar. Este processo de alteração entre a natureza restritiva da tradição modernista e a maleabilidade da pós-modernidade mostrava-se, em nível global, no desenvolvimento de mecanismos de participação e, em nível local ou periférico, no desejo de atualização.

Em 2008, a aproximação proporcionada pela ampliação dos meios de comunicação digitais tornava mais acessível o conhecimento de ações realizadas em centros distantes de referência da produção artística contemporânea (visto que dispunham de estrutura institucional para registrar e sistematizar seus feitos) do que aquelas desenvolvidas no próprio local. Neste sentido, informações coletadas por meio virtual apaziguavam a distância da periferia em relação ao centro, que poderia ser potencializada com contatos presenciais. É neste contexto de maior estreitamento que, mesmo sem ignorar uma série de manifestações em curso no próprio território nacional ou capixaba, escolheu-se a $4^{\mathrm{a}}$ edição do projeto Madrid Abierto 285 (2007) como modelo à $8^{\mathrm{a}}$ edição do evento capixaba. A relação foi intensificada pelo encontro entre José Cirillo - integrante da Comissão de Coordenação do $8^{\circ}$ Salão ${ }^{286}$ - e Jorge Díez, diretor do programa e presidente da comissão julgadora do evento madrilenho ${ }^{287}$. Ao confrontar os dois editais, é possível detectar similitudes ou adaptações, quando necessárias.

O regulamento constitui um mecanismo que proporcionava sensação de igualdade e transparência no regime democrático, representando, especialmente no Brasil, o próprio contrato entre a instituição e os interessados. Por isso, a indisponibilidade do interesse público, princípio personificado

285 Segundo Jorge Díez, a organização do projeto começou em 2002. No ano seguinte, ocorreu a chamada internacional para as inscrições e, em 2004 sua primeira edição. Entre 2004 até 2008, o evento foi anual, tornando-se bienal a partir de 2009. Disponivel em: <http://madridabierto.com/textos/2011-2012/10-anos-madrid-abierto.html>. Acesso em: 19 dez. 2017.

286 Os demais integrantes foram: Maria Helena Lindenberg (Coordenação geral), Neusa Mendes, Nenna (Atílio Ferreira) e Samira Margotto.

287 Em junho de 2008, Jorge Díez esteve em Vitória para participar do I Simpósio Internacional de artes Visuais: a natureza pública da arte. $O$ evento foi organizado pelo LEENA/UFES, do qual, José Aparecido Cirillo, é Líder. $O$ contato inicial, entretanto, ocorreu em 2007. Neste ano, José Aparecido Cirillo (Líder do Grupo LEENA, da UFES) participou do $16^{\circ}$ Simpósio de Artes Plásticas: experiências atuais em Arte Pública, realizado em Porto Alegre (RS). Na ocasião, Jorge Díez apresentou sua experiência na execução do Madrid Abierto. As apresentações foram publicadas em livro. Cf. ALVES, José Francisco. (Org.). Experiências em Arte Pública: Memória e Atualidade. Porto Alegre: Artfolio e Editora da Cidade, 2008. 
na lei n 8666/93, que normatiza licitações e contratos da Administração Pública, bem como na cultura de concursos das últimas décadas, fez do edital um dos principais componentes na realização de qualquer certame.

Até $07^{\circ}$ Salão do Mar, o detalhamento e a prolixidade, como no caso da delimitação das dimensões das obras, eram notáveis nas chamadas. $08^{\circ}$ Salão Bienal do Mar, entretanto, tentou espelhar a simplicidade e a leveza do seu modelo estrangeiro, o Madrid Abierto (Contraindicaciones, 2006) ${ }^{288}$. Assim, a natureza do objeto artístico efêmero ou temporário, o desenho de um "corredor" no qual as obras incidiriam (enquanto o evento em Madrid circunscreveu o Paseo de la Castellana, o Paseo del Prado, Calle de Alcalá e Gran Vía, o evento capixaba demarcou a avenida Marechal Mascarenhas de Moraes como ambiente, ambas são áreas centrais e turísticas das cidades), a necessidade de autorização ao usar material de terceiros, a preocupação com a compatibilidade de formatos digitais (no evento modelo, a exigência era de conformidade com o "PC", ou personal computer, em contraposição ao Macintosh, enquanto que em Vitória, a especificação privilegiava um sistema operacional específico) ${ }^{289}$, bem como a determinação de obrigações dos artistas selecionados, são pontos emulados pelo evento brasileiro.

Por outro lado, embora o desenho geral dos dois editais seja similar na maioria dos pontos, a inviabilidade local obrigou a variação. O "objeto" naquela edição do evento estrangeiro tinha caráter mais amplo ao admitir não apenas intervenções de caráter efêmero e temporário — única possibilidade adotada no $8^{\circ}$ Salão Bienal do Mar - mas também, previa dois projetos para lugares específicos, a Casa de América e a Círculo de Bellas Artes, além de trabalhos sonoros e audiovisuais a serem exibidos em outros dois espaços públicos, a Radio 3 e o Canal Metro. Ressalta-se que a inclusão de peças audiovisuais e sonoras foi adicionada ao evento na edição de 2007 (FERNÁNDEZ, 2012, p.94) 290 .

À distância em relação à pluralidade de objetos contemplados pelos eventos, soma-se aquela encontrada na participação conjugada de espaços e outras instituições. Por um lado, o Madrid Abierto, de maneira semelhante à praticada pelo próprio $7^{\circ}$ Salão do Mar, atuou de forma conjunta não apenas

288 CONTRAINDICACIONES. Convocatoria de proyectos de arte público MADRID ABIERTO 2007. 2006. Disponível em: <https://contraindicaciones.net/convocatoria_de_proyectos_de_a_1/>. Acesso em: 20 mai. 2017.

289 O pedido que os arquivos fossem compatíveis com o Windows XP, acompanhado da nomeação dos formatos doc, jpg, tif, xls, ppt, rtf ou swf indica dois fenômenos típicos do cenário institucional brasileiro: a falta de estrutura e suporte nas operações com recursos digitais e, em decorrência disso, o privilégio, ingenuamente incutidos em editais de eventos acadêmicos, seleções de pós-graduação, ou mesmo outros concursos, a determinadas empresas de software.

$290 \quad$ FERNÁNDEZ, Maria Dolores Arroyo. Arte en la calle: Evolución del concurso internacional Madrid Abierto en el periodo 2004-2007. Arte y Ciudad: Revista de Investigación. № 2, Octubre de 2012, pp.87-97. Disponível em: <http://arteyciudad.com/revista/index.php/num1/article/view/74/129>. Acesso em: 20 mai. 2017. 
com outras instituições, como as já citadas - Casa de América, Círculo de Bellas Artes, Radio 3 e o Canal Metro -, mas dividiu a cidade com outro evento relevante, o ARCO291. Já o $8^{\circ}$ Salão Bienal do Mar, mesmo tendo apoio de entidades, não possuiu a amplitude obtida com a política de variedade de pontos de mostra - espaço urbano, edifícios específicos, rádio e canal de televisão - bem como com a fusão de eventos análogos, demarcando a diferença efetiva de inserção do evento madrilenho em relação à oitava edição do salão brasileiro.

Outro aspecto, relacionado às diferenças, que deve ser destacado entre um evento e outro, observável ainda a partir dos editais, é o peso da estrutura burocrática. Se por um lado, a leveza madrilenha requisitava uma identificação por meio do "DNI" (Documento Nacional de Identidad), por outro, a pujança brasileira exibia severidade e controle ao solicitar RG, CIC, PIS, comprovante de residência, além de certidão de regularidade fiscal com a Receita Federal e Receita Estadual do Estado de origem do candidato. Se no primeiro caso, a inscrição era universal, chamando artistas do mundo todo para a participação, no evento capixaba, apenas brasileiros natos, naturalizados e estrangeiros legalmente residentes no país eram admitidos ${ }^{292}$. Além da complexidade dos documentos obrigatórios para a inscrição, apenas duas formas de envio eram admitidas: presencial ou por correio. Diversamente, o evento espanhol admitia também o encaminhamento por meio de correio eletrônico.

A precisão encontrada em determinados pontos do edital brasileiro, falta, entretanto, em outros. A nomeação da comissão de seleção ou curatorial é fornecida no regulamento do Madrid Abierto, enquanto $08^{\circ}$ Salão Bienal do Mar não declara seus componentes neste documento293. Outro ponto sensível da tendência bipolar da cultura burocrática nas instituições explícita na análise dos editais, paradoxalmente, revela um alívio do controle regulatório sobre a ação de agentes culturais: o evento espanhol especifica um máximo de recursos (12.000 euros), condicionado à aprovação de orçamento detalhando custos totais da obra - incluindo gastos com viagem, alojamento, produção, transporte, montagem e os honorários do autor, este último limitado a 2.000 euros - e possíveis dotações próprias; já o $8^{\circ}$ Salão Bienal do Mar fixa o valor único de cada premiado (10.000 reais) e atribui suas obrigações - custos com equipamentos e materiais, transporte, montagem, preservação, manutenção e desmontagem da obra - sem especificar o montante do pró-labore artístico. Esta imprecisão é, sem dúvida, benéfica ao artista e ao evento, expondo ainda uma falta de profissionalização do meio.

\footnotetext{
291 A criação do evento foi motivada pela $A R C O$, importante feira de arte contemporânea realizada pela IFEMA, em Madrid. Ver: <http://www.ifema.es/arcomadrid_01/>. Acesso em: 20 mai. 2017.

292 A restrição foi imposta pelo setor jurídico da PMV, mediante a alegação que a instituição governamental teria dificuldade em efetuar o pagamento.

293 É preciso esclarecer que entraves burocráticos dificultavam as contratações dos profissionais participantes. A equipe responsável pela organização (composta unicamente por profissionais locais), por exemplo, iniciou seu trabalho antes de ser oficialmente instituída. Ressalta-se que, as reuniões tiveram inicio em 7/06/2008.
} 
Finalmente, a maleabilidade imprevisível do certame capixaba, na qual as regras são fortes ou frouxas dependendo do caso, teve no seu único convidado, o artista francês Jean-Blaise Picheral, sua manifestação mais incômoda. Diferentemente do gabarito espanhol, que explicitou a existência de artistas convidados para o evento, o regulamento do $8^{\circ}$ Salão Bienal do Mar não faz qualquer menção a essa possibilidade. 0 estranhamento é coroado com o caráter não efêmero da obra e suas características formais, mais próximas do ethos modernista do que da relação interdisciplinar proposta para os projetos que seriam selecionados.

O perímetro escolhido para as intervenções também não foram idênticos entre modelo e espelho. Enquanto o Madrid Abierto delimitou Paseo de la Castellana, Paseo del Prado, Calle de Alcalá e Gran Vía, área central e turística da cidade, locais em que estão sediadas instituições parceiras (Circuito Bellas Artes e Casa de América), o $8^{\circ}$ Salão Bienal do Mar optou por um trecho que, apesar de estar localizado na área histórica da cidade, era relativamente distante dos principais marcos arquitetônicos divulgados nos guias turísticos de Vitória. Neste sentido, o local designado no edital para a realização das intervenções era uma parte menos atrativa do Centro histórico de Vitória: a Avenida Marechal Mascarenhas de Moraes, popularmente denominada de Avenida Beira-Mar. Ressalta-se que, na época do evento, os muros que contornam a orla estavam em obras (Fig. 30).

\footnotetext{
Essa área é relativamente esquecida como configuração urbana da cidade - parece que se pode afirmar que é uma região demarcada por um não pertencimento à imagem da cidade -, definida como um corredor de acesso entre o velho centro e regiões mais nobres, residenciais e comerciais, da cidade de Vitória. A provocação de um redirecionamento do olhar e da percepção para esse espaço do esquecimento constituiu uma das propostas de imaginabilidade da cidade por meio da intervenção artística da Bienal (CIRILLO; MENDES, 2009b, p.166) ${ }^{294}$.
} 
Figura 30 - Trecho selecionado durante a visita da Comissão de Organização

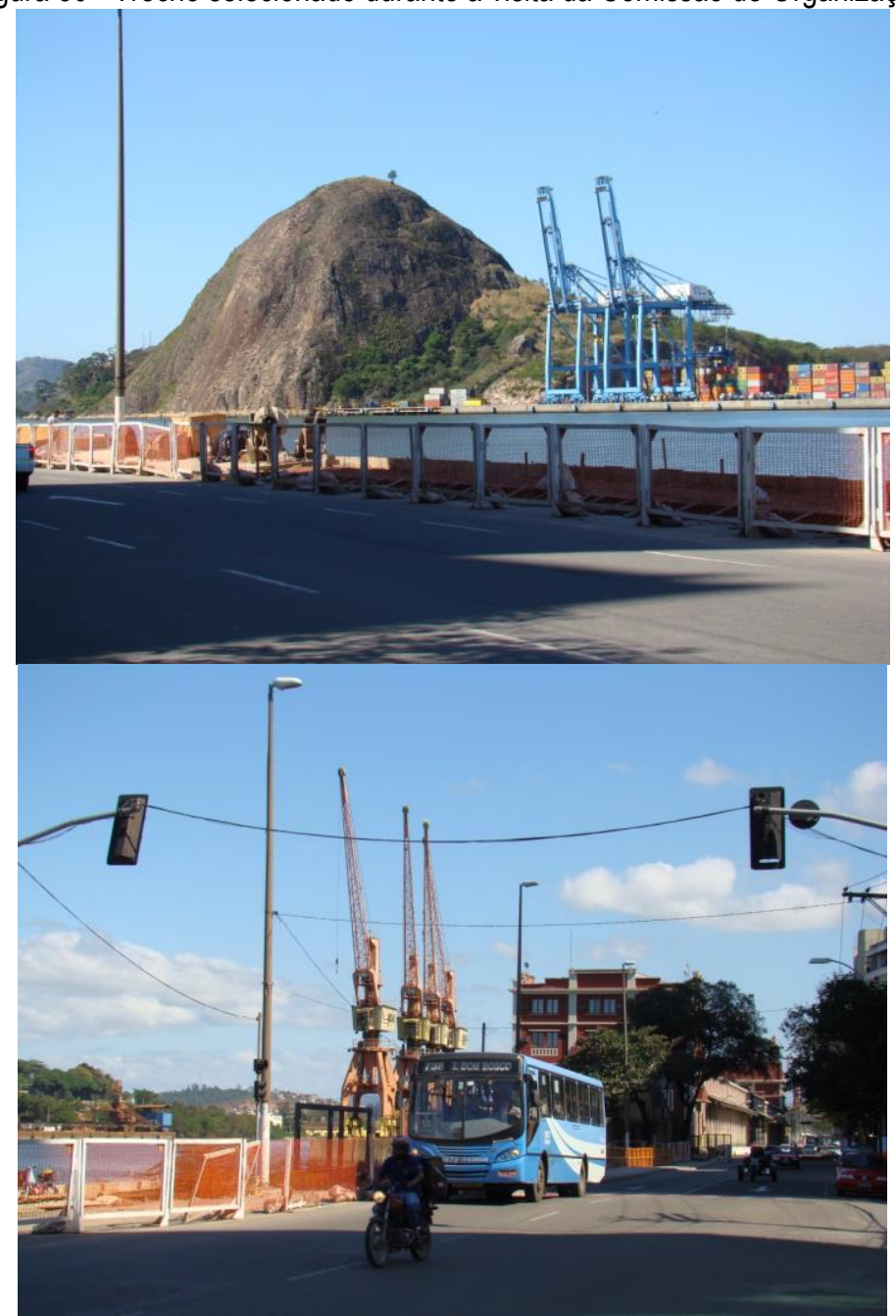

Fonte: Arquivo da autora. Foto: Maria Helena Lindenberg (2008).

O contraste estratégico entre o palco do Madrid Abierto - assim como os atraentes armazéns do $7^{\circ}$ Salão do Mar - e a zona menos exaltada nos guias turísticos locais que serviu de cenário ao $8^{\circ}$ Salão Bienal do Mar, possivelmente tenha influenciado o baixo interesse midiático pelo evento. $\mathrm{A}$ repercussão na imprensa foi muito inferior à edição anterior da mostra, sendo que a maioria dos textos jornalísticos reproduz ou faz apenas pequenas alterações nos releases enviados pela assessoria de imprensa da SEMC/PMV. Também reduzido foi o número de inscritos em relação à edição anterior (410, em 2006, e 110, em 2008) apesar da quantidade e do valor dos prêmios terem sido substancialmente aumentados. Os participantes na $8^{a}$ edição foram majoritariamente do próprio Espírito Santo ${ }^{295}$, em contraposição à edição anterior, na qual predominou a inscrição de paulistas ${ }^{296}$.

295 Dos 110 inscritos, 47 eram do Espírito Santo, seguido por São Paulo com 25, Rio de Janeiro com 10, Minas Gerais com 8, Rio Grande do Sul com 5, Paraná com 4. Dos estados do Pará, Bahia, Distrito Federal e Santa Catarina, 0 Salão recebeu 2 inscrições de cada, enquanto do Ceará e Rio Grande do Norte, apenas 1. Disponível em: 
Provavelmente, o período reduzido do tempo previsto para a elaboração dos projetos (13/08 a 4/10/2008) e a alteração no objeto de seleção em relação à $7^{a}$ edição repercutiu no número reduzido de interessados, especialmente de artistas de outros Estados. Afinal, como atender a proposta do edital - dedicado a práticas artísticas que estabeleçam uma relação interdisciplinar com uma cidade, seus espaços e habitantes -, sem conhecer o local ou conhecendo-o parcamente? Sabe-se que tanto a cidade de Vitória quanto o evento em questão não apresentam aquela sensação de familiaridade proporcionada pela mídia. Além disso, o material disponibilizado no site e no folder do evento era restrito às intangíveis imagens de satélite da área apropriadas do Google $\mathrm{Maps}^{297} \mathrm{e}$, fotos panorâmicas da área proposta (Figs. 31, 32 e 33). Não sem razão, o número mais expressivo de inscritos foi do próprio Espírito Santo, também foram os projetos de artistas locais que dialogaram de forma mais pronunciada com questões peculiares ao local298.

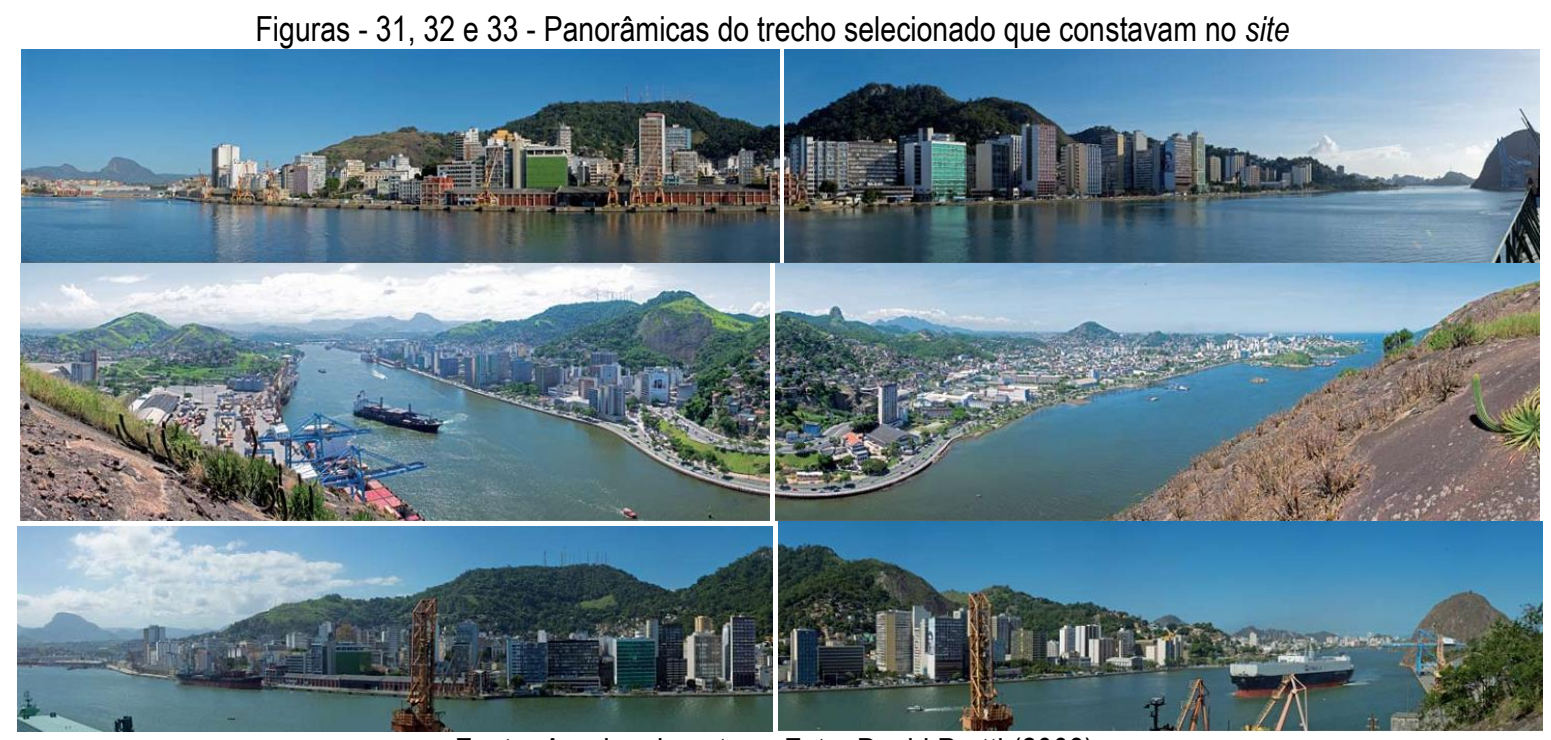

Fonte: Arquivo da autora. Foto: David Protti (2008).

Representativo do processo de transição entre o modelo modernista e a pós-modernidade é a proliferação de mecanismos de participação. Além do edital, os contratos firmados entre artistas e a SEMC/PMV, a disponibilização de informações no site da Prefeitura de Vitória, a impressão de catálogo

<http://gazetaonline.globo.com/_conteudo/2008/12/44285-

obras+da+bienal+do+mar+interagem+com+paisagem+do+centro+de+vitoria.html>. Acesso em: 03 abr. 2014.

296 Conforme já foi exposto, na $7^{a}$ edição, em 2006, o Salão recebeu 410 inscrições, das quais, 76 eram do Espírito Santo. Entretanto, a participação de artistas de outros estados brasileiros foi intensa. Neste ano, artistas de 19 estados brasileiros enviaram propostas, entre os quais, é possível destacar os seguintes: 117 eram de artistas de São Paulo, 63 do Rio de Janeiro, 41 da Paraná, 31 de Minas Gerais. A tabela completa consta no catálogo do evento. MARGOTTO, Samira (Org.). $7^{\circ}$ Salão do Mar. Vitória: Secretaria Municipal de Cultura/ Casa Porto das Artes Plásticas, 2006, p.83.

$297 \quad$ A utilização dessas imagens de satélite, hoje muito difundidas, constituía em 2008 uma novidade no Brasil. Cabe informar que o serviço teve início em 2005 nos Estados Unidos.

298 São exemplos disso: Caminho das Águas, de Piatan Lube, grandePEQUENAcatraia, de Marcelo Gandini, 0 Retorno de Araribóia, do Coletivo Maruípe e, Ego trip pré-sal, de João Wesley e Sandro de Souza. 
com entrevista dos artistas e tradução dos textos para o inglês representam tentativas de estabelecimento de dispositivos de transparência. 0 contrato e o edital, particularmente, reforçam 0 cenário meritocrático, aproximando a prática artística ao profissionalismo trivial comum às demais profissões. Como se sabe, entretanto, a hierarquia persiste. Os chamados "convidados", aqueles que não se submetem ao crivo da seleção, geralmente por conta de sua expertise artística, revelam 0 incômodo institucional com estes mecanismos.

A disponibilização de informações do $8^{\circ}$ Salão Bienal do Mar em sites dedicados, embora regular no seu período de vigência, foi completamente desabilitada depois. A exceção de restos de informação persistentes, no domínio da PMV e em blogs interessados, não há um site que mantenha os arquivos sistematicamente organizados e disponíveis verdadeiramente ao público, os documentos do evento só podem ser consultados na sede da instituição promotora. No caso do Madrid Abierto, o material documental gerado integra o arquivo instalado no ano de 2011, em Matadero (Centro de Creación Contemporánea). Para a consulta pública ao conjunto documental é necessário solicitar autorização e, apenas de forma parcial, os registros estão disponíveis no site www.madridabierto.com ${ }^{299}$. Contradizendo o sugerido pela palavra "aberto", no título do evento e os benefícios atribuídos à rede eletrônica (abolição de fronteiras geográficas, 0 acesso à distância, à informação comum, livre e imediata), a noção de abertura é parcial e, no limite, mais utópica do que efetiva.

No tocante ao catálogo, o $8^{\circ}$ Salão Bienal do Mar buscou a disseminação da informação por duas vias. A primeira, pela inclusão da tradução dos escritos para a língua inglesa, deixando evidente a vontade de estabelecimento de diálogo com o leitor estrangeiro. Por outra via, além dos textos convencionais de autoridades, organizadores e curadores, incorporou trechos dos projetos encaminhados, além de entrevistas aos artistas. As apresentações foram, majoritariamente, resumidas pela Comissão Editorial300 - visando equalizar as dimensões textuais dos projetos - e submetidas à aprovação dos autores. A entrevista foi padronizada em três perguntas, cujas respostas não poderiam ultrapassar 3.000 caracteres. Neste espaço era também permitido que o artista acrescentasse qualquer dado que considerasse relevante.

Projeto e entrevista formavam, em conjunto com fotografias dos trabalhos em execução e, por vezes, imagens retiradas das propostas, a tríade que integra tanto o resultado final como o processo de criação. Entretanto, seja na seleção e disposição das imagens ou no formato do diálogo por perguntas

299 A informação consta no texto escrito por Jorge Díez. Disponível em: <http://madridabierto.com/textos/20112012/10-anos-madrid-abierto.html>. Acesso em: 19 dez. 2017.

$300 \quad$ Composta por Priscila R. Rufinoni e Samira Margotto. 
dirigidas, é a voz institucional que prevalece sobre as demais. A inclusão foi alargada dentro de um contingente semelhante à sistemática da democracia representativa da política do Estado que, por meio do voto, produz a sensação da participação popular com o fito de legitimar decisões deliberadas por uma minoria. Convém reconhecer, entretanto, que ao menos em tese, tentou-se, no catálogo do $8^{\circ}$ Salão Bienal do Mar, incutir uma perspectiva de partilha. Tal perspectiva, evidentemente, implicou exclusões e tensões, paradoxo inevitável à topografia e à lógica do pensamento democrático. Conforme dimensionou Chantal Mouffe (2005), relações de poder são constitutivas do social, portanto, "a questão principal para a política democrática não é eliminar o poder, mas [...] construir formas de poder mais compatíveis com valores democráticos" $(2005$, p.19) 301.

\begin{abstract}
Ao precaver-nos contra a ilusão de que uma democracia perfeitamente bem-sucedida possa ser alcançada, força-nos a manter viva a contestação democrática. Abrir caminho para 0 dissenso e promover as instituições em que possa ser manifestado é vital para uma democracia pluralista e deve-se abandonar a própria ideia segundo a qual poderia haver um tempo em que pudesse deixar de ser necessário, pois que a sociedade seria a tal ponto bem-ordenada. Uma abordagem "agonística" reconhece os limites reais de tais fronteiras e as formas de exclusão que delas decorrem, ao invés de tentar disfarçá-los sob o véu da racionalidade e da moralidade (MOUFFE, 2005, p.22).
\end{abstract}

Na medida dos limites institucionais, entre as perguntas (mais provocativas que consensuais) e as respostas dos artistas (que oscilavam entre divergir ou procurar esclarecer), algumas inquietações se evidenciaram, embora, predominantemente sutis. Houve, entretanto, um caso, que fugiu à regra302 e, comentá-lo, ajuda a entender por outro ângulo, tensões subjacentes entre centro e periferia no território brasileiro, bem como a utilização instrumental da "renovada" função social da arte no discurso artístico.

Insatisfeito, especialmente com o emprego do termo "ironia", presente em duas das perguntas encaminhadas, um selecionado exigiu que as mesmas fossem reformuladas ${ }^{303}$. Para tanto, enviou um extenso e-mail, no qual, expõe seu entendimento da condição de um artista em início de carreira no país ${ }^{304}$. Segundo ele, ser artista no Brasil "não é gostoso/prazeroso". "Meu trabalho tem um pouco de humor, mas não é engraçado e nem divertido. Entende?".

301 MOUFFE, Chantal. Por um modelo agonístico de democracia. Rev. Sociol. Polit.. N.25. Curitiba Nov. 2005. pp.11-25. Disponível em: <http://www.scielo.br/pdf/rsocp/n25/31108.pdf>. Acesso em: 20 mai. 2017.

${ }_{302}$ Ressalta-se que, o nome do artista será preservado, pelo simples fato que mencioná-lo nada acrescentaria à discussão proposta. Além disso, foi uma correspondência informal entre instituição e artista.

303 Considerando que era facultado ao artista responder o que desejasse, ao invés de alterar as perguntas, optou-se, em comum acordo, por apresentar imagens do seu trabalho no espaço destinado à entrevista. A exigência de reformulação pode ser apreendida do seguinte trecho do e-mail do artista: "Caso tenha vontade de reformular suas perguntas, responderei com mais clareza ainda, porém, a resposta depende da pergunta". E-mail encaminhado em 22 de dezembro de 2008.

304 Segundo ele, a remuneração quando ocorre é irrisória, o trabalho cotidiano é árduo e necessita reunir habilidades diversas (produzir a obra, escrever projetos e criar uma rede de conexões para o trabalho ser incluído em exposições e 
Em um esboço de resposta à indagação sobre a relação possível de ser estabelecida entre sua proposta (irônica na pergunta formulada pela Comissão Editorial) e os fluxos de uma cidade como Vitória, o artista explica o porquê de, apesar de considerar seu ofício penoso, parcamente remunerado e destituído de prazer, continua a fazê-lo.

Respondendo a sua pergunta de uma maneira bem séria (ignorando a parte da ironia), penso que desenvolver o meu projeto [...] em Vitória é de uma maneira bem direta estabelecer conexões com o Brasil na sua grande extensão. Artistas novos apenas pensam em entrar em uma galeria famosa e acha (sic) que isto resolve tudo, ou que no caso de artistas mais consagrados ainda acabam apenas desenvolvendo exposições em galerias de arte e feiras de arte - em outras palavras, em pouco tempo o trabalho se transforma em uma moeda e deixa de ser arte, cultura, e comprometimento com o nosso país, com a nossa educação e com a nossa formação cultural. Acredito, e isto pode ser comprovado no meu $\mathrm{cv}$, que a arte deve ser mostrada, deve ser pensada, feita e trocada pelos artistas e pelo Brasil por um todo. Eu tenho este comprometimento em espalhar "cultura" e me preocupar com isto - por isto gosto de viajar, conhecer outras cidades "fora até do circuito comercial/convencional" das artes e estabelecer trocas com outros artistas/cidades (E-mail encaminhado à organização em 22-12-2008, grifos meus e as palavras entre aspas destacadas pelo artista).

Conforme pode ser detectado ou presumido no escrito acima, para ele, participar do $8^{\circ}$ Salão Bienal do Mar fazia parte de sua preocupação e comprometimento em espalhar "cultura", até mesmo em cidades apartadas do "circuito comercial/convencional", o que poderia ser comprovado verificando seu currículo. $O$ discurso não é apenas pessoal, mas faz parte de um eco em tom menor do próprio discurso do evento e explícita suas aporias. Por exemplo, há um paradoxo entre seu intuito e sua atuação, também presente no caso de outros selecionados. Apesar do currículo extenso - com mais de sessenta exposições, reunindo as individuais e as coletivas - suas participações foram em instituições renomadas e, majoritariamente, localizadas em São Paulo ou em outras capitais do Sudeste e do Sul, bem como, em cidades no exterior, nenhuma cidade da Região Norte, por exemplo, foi registrada. No Centro Oeste, por duas vezes, o artista foi selecionado no Salão Nacional de Arte de Goiás, porém, tal como no caso do $8^{\circ}$ Salão Bienal do Mar, seu discurso de comprometimento é esvaziado, já que nos dois eventos, tanto a premiação pecuniária e a participação de curadores nacionalmente renomados quanto a publicação impressa, são fatores que excluem à noção de benevolência com cidades fora do circuito. Todavia, em 2005, o artista realizou uma exposição na Galeria Homero Massena, em Vitória, sua única individual naquele ano, tendo sido um dos quatro selecionados, entre os vinte e nove inscritos (TEIXEIRA, 2010, p.206). Ao solicitar que fosse verificado em seu currículo seu interesse em estabelecer conexões "com o Brasil na sua grande extensão",

mostras importantes para a carreira). Ele difere "o jovem artista comprometido" - categoria a qual se inclui -, do artista jovem apenas interessado no mercado e, do artista já consagrado, que desenvolve somente exposições em galerias e feiras de arte. 
possivelmente, essa exposição poderia comprovar sua disposição em atuar além de locais e instituições notoriamente reconhecidas.

O caso utilizado não foi único, mas por ser mais agudo, é exemplar, pois torna possível retomar, por outro ângulo, as tentativas de estabelecimento de dispositivos de transparência por meio do edital e do contrato, além dos incômodos com esses mecanismos. Logo após ter sido selecionado, o artista enviou um e-mail para a instituição perguntando sobre a data que seria efetuado o depósito da primeira parcela do seu prêmio, visto que seu projeto era complexo e envolvia mão de obra terceirizada.

\begin{abstract}
Bom, sei que os meus documentos demoraram uns dias a mais, porém, preciso saber sobre o depósito da verba - quando ficara pronto para eu poder dar andamento no meu projeto senão não conseguirei ser eficiente e cumprir todos os prazos de mão de obra terceirizada para o dia 5 de dezembro, abertura do evento. Peço atenção especial no meu caso. Obrigado (E-mail encaminhado pelo artista para o endereço eletrônico bienaldomar@vitoria.es.gov.br, em 13-11-2008).
\end{abstract}

Em resposta, a instituição esclareceu que o pagamento só seria realizado após o artista encaminhar o contrato assinado ${ }^{305}$. A investida insinuada por e-mail de figurar como exceção, presente no pedido de atenção especial no seu caso 306 apesar da lentidão no envio da documentação necessária, é um claro indicativo de que a retórica da democracia ainda contrasta com os termos de exceção que regem um campo pouco estruturado e profissionalizado, no qual se mesclam expedientes públicos e privados, como talvez se ressalte a contrapelo das falas do jovem artista. Sem possuir o poder de soberania que lhe permitiria alterar as leis, criando um "estado de exceção" - no sentido atribuído ao termo por Carl Schmitt 307 , no qual, a lei não seria eliminada, mas, poderia flutuar como um elemento indeterminado - em um campo percebido como não estruturado, o artista vincula a noção da necessidade pessoal à de atender ao próprio evento, já que assim, poderia realizar seu trabalho no dia previsto para a abertura. Em um campo com preceitos pouco claros, tal como o das artes, a exceção como regra torna-se nitidamente mais explícita. Entretanto, até as vésperas do encerramento do evento, o artista ainda não tinha apresentado sua performance (que seria executada por outro artista

\footnotetext{
305 Como contraste entre os mecanismos, cabe ressaltar que um edital de arte vale como qualquer outro edital, contrariando a lógica maleável do campo artístico. A instituição promotora do evento, vinculada à PMV, não possuía autonomia para efetuar ou facilitar o pagamento sem atender as exigências legais, que eram atribuição de outros setores do órgão governamental. Cabe esclarecer que apesar de constar no edital a documentação necessária para a confecção do contrato, alguns dos documentos exigidos, tinham prazos exíguos de validade.

306 Por que ele deveria receber tratamento diverso aos demais selecionados? Uma resposta possível pode ser aferida da consideração que seu projeto era "sofisticado" por conectar e estabelecer pontes "entre arte, moda, design, e arquitetura", diferindo-se, portanto da maioria, visto que para ele: "hoje em dia ou o performer fica pelado, ou usa roupa de pai de santo (calça de capoeira, etc.)" (Trechos do e-mail encaminhado à organização, em 22-12-2008).

307 Cf. SCHMITT, Carl. Teologia política. Tradução de Elisete Antoniuk, Belo Horizonte: Del Rey, 2006.
} 
contratado que estava no exterior, segundo ele informou à instituição) ${ }^{308}$. Outro dado que talvez explicite a falta de estrutura do campo artístico, em flagrante desacordo com o ideal de democratização do edital e do evento, está na incompreensão dos papéis de cada um dos agentes. Sem entrar no mérito das perguntas enviadas aos artistas, que tinham 0 intuito provocativo, elas foram confeccionadas por profissionais da área de artes, cujo papel parece ser pouco relevante, se não for meramente laudatório. O mesmo vale para a relação contratual entre artistas e instituição. Sem fazer juízos apressados, é notável como há uma espécie de descrédito tanto com os mecanismos de seleção quanto com os profissionais do campo artístico quando os mesmos não adotam posturas consensuais. $\mathrm{Na}$ verdade, talvez nesse ponto se explicite novamente aquele limite tênue entre centros e periferias, no qual se nomeia o diverso - a mulher, o não europeu, o não paulistano - para circunscrevê-lo junto ao universo hegemônico por condescendência. Descontando-se o problema já mencionado do lugar discursivo da instituição em tais casos, não foi incomum a má recepção das entrevistas. Ficou clara nas reações a concepção de que a crítica, quando há, deve vir em prol do próprio trabalho e ser, no limite, comentário autorizado, nunca produzir realmente um contexto dialógico tenso ou qualquer dissenso, mesmo aquele conduzido nos limites do catálogo institucional. Mais do que cobrar por uma profissionalização no sentido estritamente liberal, divisão de trabalho, ou constituição de uma classe criativa, o que se explicita é o quanto o discurso e as práticas se mostravam discrepantes, e como, talvez pelo descompasso, esse momento de democratização artística, do qual o $8^{\circ}$ Salão Bienal do Mar é exemplo, parece ter se constituído como apenas uma bolha, sem consequências realmente duradouras.

Apenas nas entrelinhas da correspondência do artista com a instituição, a tentativa de demarcação entre centro e periferia subjaz implícita nas solicitações efetuadas. Em um período em que os discursos tentavam sublinhar que essas distinções estavam se dissipando, que as fronteiras estavam ficando porosas, menções explícitas aos centros hegemônicos como locais de legitimação eram evitadas ou deveriam ser camufladas (conforme debatido no item Formatos e Fronteiras no capítulo anterior). Por essa perspectiva, o próprio $8^{\circ}$ Salão Bienal do Mar, que utilizou o Madrid Abierto como modelo, sem explicitar nos documentos oficiais sua referência, também necessitou recorrer a recursos que podem ser aproximados (mas, não equiparados) aos utilizados por esse artista. Nesse sentido, vale mencionar que sendo um projeto insólito no âmbito das instituições formais de arte no

308 Em 28 de janeiro de 2008, a coordenadora do evento encaminhou o seguinte e-mail ao artista: "Devemos lembrarIhe que a Bienal termina no próximo dia 05 de fevereiro e não será prorrogada. Ainda não temos material escrito nem documentação da realização da sua obra". No dia seguinte, ele respondeu: "Estou me programando para ir entre o dia $30 \mathrm{e}$ 31. [...]. Chegou do Japão o performer que produz minhas ações. Estou negociando com ele - afinal já faz 2 anos que ele executa as performances pra mim. Desculpe a demora para executar o trabalho, tirando os atrasos - tive que resolver questões pessoais nestas semanas e agora posso finalizar com sucesso o trabalho". 
Espírito Santo, para efetivá-lo, nas reuniões técnicas com os outros setores da PMV, a alusão ao evento espanhol (e também a outros, entre os quais, o Arte/Cidade, no Brasil) servia para validar a iniciativa local adaptada. A autoridade simbólica, portanto, persiste tanto nas microrrelações no campo da arte (conforme foi exemplificado no caso aqui discutido) quanto no âmbito macro.

No âmbito macro, a preservação da autoridade simbólica, pode ser aferida na generalização do modelo urbano baseado no conceito de "cidade global"309, sistematizado por Saskia Sassen em seu livro The Global City: New York, London, Tokyo, publicado em 1991. Muito embora o conceito "cidade global" de Sassen seja direcionado às grandes metrópoles mundiais, é possível expandi-lo às cidades que compõem suas margens. É o que propõe Mariana Fix, adicionando uma diferenciação entre as distintas classes de cidades participantes deste ranking mundial. Diferentemente dos centros globais, que disputam a manutenção da hegemonia, beneficiárias das melhores posições no grid de largada, a periferia, retardatária histórica, almeja a obtenção de melhor visibilidade global:

A tese das cidades mundiais ou globais assume importância tanto em cidades como Londres e Nova York, na defesa de ações para manter o status global, quanto em cidades asiáticas ou latino-americanas, nas propostas de políticas para melhor inseri-las na suposta rede de cidades globais (FIX, 2007, p.164).

Apesar de, o modelo urbano baseado no conceito de cidade global tenha restaurado cidades, ou pelo menos pontos específicos, e reposicionado o setor artístico na economia, não é possível ignorar os custos deste processo tanto para as cidades, quanto para a arte. Para as cidades, especialmente para sua população, o enobrecimento das áreas centrais criou pequenos cenários em que experiências urbanas são idealizadas. Por outro lado, para determinados setores artísticos, especialmente aqueles impregnados por concepções modernistas, têm sido penoso 0 trabalho junto a outros ramos do entretenimento a fim de compor o cenário turístico das cidades globais. Assim, sem aclamar ou tentar descartar completamente a relevância, tanto do modelo urbano alicerçado no conceito de cidade global, quanto desses eventos de arte no espaço urbano (que são desdobramentos, nos centros maiores, do processo de disputa por visibilidade de cidades ou regiões), não é possível,

309 Segundo, João Sette Whitaker Ferreira, tanto "[...] as nomenclaturas 'cidade-mundial' e 'cidade-global', foram adotadas na teorização sobre o 'novo' papel das metrópoles na economia globalizada", ressaltando que no seu entendimento, "[...] ambas designam um mesmo conceito, inserido em uma mesma corrente teórica, sujeita evidentemente a pequenas variações." (FERREIRA, 2003, p.24). Ferreira afirma, ainda que: "O termo 'cidade-mundial', utilizado pela primeira vez por Patrick Gueddes, em 1915, foi retomado [...] por Peter Hall em 1966, com sua obra World Cities". Estudos posteriores impulsionaram a discussão relacionando o termo "[...] de forma direta com as transformações econômicas globais decorrentes da revolução da informática e da reestruturação produtiva." Entretanto, embora haja "[...] uma extensa produção bibliográfica internacional sobre o conceito de cidade-global, [...] os trabalhos de Sassen talvez sejam as sistematizações mais recentes a respeito, embora também Hall e Friedmann tenham retomado a discussão após o primeiro trabalho da autora." O trabalho em questão é o livro The Global City: New York, London, Tokyo, publicado em 1991. (ibid, p.45 e 46). FERREIRA, João Sette Whitaker. São Paulo: o mito da cidade global. Tese (Doutorado em Estruturas Ambientais Urbanas) - Faculdade de Arquitetura e Urbanismo/USP, São Paulo, 2003. 
entretanto, ignorar a impotência da consolidação de ambos em um cenário destituído das mesmas condições estruturais e mesmo humanas, no sentido da consolidação de uma classe artística como apontado anteriormente. Foi o caso, do $8^{\circ}$ Salão Bienal do Mar.

A comparação entre o edital capixaba e o espanhol demonstrou a manutenção da estrutura de base, as adaptações e pontos problemáticos. As imposições burocráticas - exigências de documentação, restrições de recebimento, não especificação da Comissão Curatorial - e limitações orçamentárias são entraves para a realização de eventos artísticos no Brasil, especialmente em cidade de menor porte, não representando exatamente as vontades de seus organizadores. Legislação, delegação e negociações dependem da existência de um circuito estabelecido, profissional e, acima de tudo, de especialização. Tais quesitos, escassos na periferia, dificultam a realização de um evento nos moldes produzidos nos grandes centros.

Finalmente, ainda que o padrão utilizado pelo $8^{\circ}$ Salão Bienal do Mar tenha replicado pontos fundamentais do modelo implementado pelo Madrid Abierto, ao variar o "objeto", selecionando apenas intervenções efêmeras ou temporárias, ao delimitar um perímetro do Centro histórico de Vitória, não sublinhado nos guias turísticos locais, a bienal capixaba afastou-se do caráter mais espetacular tanto de sua $7^{a}$ edição quanto do evento espanhol.

\subsubsection{Disciplinaridade e "democracia" no "salão do campo ampliado"}

Embora 0 ambiente virtual nos centros urbanos ${ }^{310}$, esfera pública por excelência graças à abertura dos protocolos que baseiam o funcionamento da internet, tenha paulatinamente adquirido 0 status de território privilegiado do debate democrático nos últimos anos - nos ambientes do Facebook, Whatsapp, Tinder, Twitter etc. - parte considerável da produção artística contemporânea manteve-se fiel ao espaço analógico. É notável que, sob o rótulo de intervenção urbana e, em oposição à noção de lugares fechados, o ambiente citadino tenha sido tão evocado como bandeira de frescor em pleno século XXI.

\footnotetext{
310 Considera-se, ao mencionar os centros urbanos, a ressalva de Gerardo Mosquera: "De todo modo, a circulação 'internacional' da arte a que me refiro torna-se limitada. A maior parte da humanidade permanece em zonas de silêncio, fora de todo circuito, até da internet. Se pensarmos nas grandes massas de população na África, Ásia e América Latina que permanecem unplugged, falar em 'universalidade' ou em circulação internacional é quase retórico." (MOSQUERA, 2003, p.82). A fala do autor pode levar a supor que zonas de silêncio estão restritas apenas aos recantos mais remotos do planeta. Entretanto, em Porto Velho, capital do estado de Rondônia, em 2010, por exemplo, apenas áreas próximas as instituições de maior porte, como bancos, possuíam sinal de internet em intensidade que permitia a navegação, conforme foi detectado pela autora desta tese.
} 
Contemporaneidade, atualização, ampliação espacial, democracia, autoria reformulada, interação e imprevisibilidade são alguns dos adjetivos encontrados em diversas apresentações de eventos de intervenção urbana. Essas qualificações reiteradas e, muitas vezes, absorvidas sem grandes questionamentos, entretanto escondem outras complexidades. Algumas delas foram objetos de escrutínio no capítulo dedicado aos coletivos e serão aqui retomadas e revistas de forma abreviada. Duas chaves podem ser evocadas para analisar a miríade de aspectos suscitados pelo entusiasmo na utilização do espaço urbano na arte contemporânea por meio da proposta do edital e dos projetos apresentados no $8^{\circ}$ Salão Bienal do Mar: disciplinaridade e democracia, termos que se fundem e se confundem, no entrelaçamento das relações entre arte e os fluxos de uma cidade.

\subsection{2 - Ditames disciplinares e a dinâmica urbana}

A dificuldade das instituições periféricas cumprirem os ditames disciplinares é um dos impulsos em direção aos apelos alternativos nos discursos da arte contemporânea. A indisponibilidade do espaço expositivo da Casa Porto de Artes Plásticas - que estava interditado e aguardando restauro, em 2008-, aliado à ausência de outro local de impacto estético à altura da edição anterior do salão, tornou o espaço urbano uma alternativa imediata à conjuntura imposta. Este novo território demandava know how e recursos diferenciados para apresentar um conjunto de obras no perímetro urbano e a necessidade de acionar outros aparatos institucionais para sua efetivação. Assim:

Dizer que o discurso subversivo da máquina da guerra artística necessitou do filtro institucional para ser posto em exposição pelo poder oficial quer, então, dizer muito sobre a essência da própria arte contemporânea. Inúmeras manobras foram necessárias para a efetivação de um diálogo entre instâncias que possuem competências diversas. Manobras que começaram dentro da própria instituição promotora, também multifacetada em setores, prolongaram-se entre outros órgãos oficiais e empresas privadas que respondem por cada pedaço do espaço urbano, em uma partilha tensa, especialmente no caso de Vitória, capital-ilha, com um porto na região central (RUFINONI, MARGOTTO, 2013, p.242).

No edital do evento as manobras dentro da própria instituição promotora, transparecem no item que procura evidenciar a soberania da Comissão Curatorial|311 relativa à competência de avaliar um projeto artístico, reservando aos demais órgãos da PMV apenas à observância de exequibilidade: a Comissão Curatorial "consultará, quando necessário, uma comissão técnica312 - que opinará sobre a

\footnotetext{
311 Os membros da Comissão Curatorial foram: Agnaldo Farias, Marilúcia Bottallo, Maria Helena Lindenberg, Nenna e Neusa Mendes.

312 Os membros da Comissão Técnica foram: Clemir Meneghel, Jackson R. A. de Araújo, José Gomes Rodrigues e Luciano de Oliveira.
} 
viabilidade de execução do projeto proposto" (Edital, item 3.1, grifo meu). Sem urdir laços com outros órgãos, a execução de uma obra como Caminho das Águas, de Piatan Lube dificilmente seria realizada. Para o artista pintar sua extensa faixa azul nas vias públicas, a equipe de limpeza urbana varreu e lavou o chão e a Guarda Municipal interrompeu o trânsito nos locais em que a linha atravessava 0 asfalto. A proposta da intervenção O Retorno de Araribóia, do Coletivo Maruípe, consistia em deslocar por alguns pontos de Vitória uma réplica idêntica ao monumento escultórico em homenagem ao índio, encomendado pelo poder público estadual, na década de $1950^{313}$, ao artista Carlo Crepaz (1911-1992). Para a retirada do molde, diretamente da obra original (Fig. 34), foi indispensável a autorização da própria SEMC/PMV. Seu transporte necessitou de um caminhão munck (providenciado por intermédio do poder municipal) para os traslados pelos diversos pontos da cidade (Fig. 35) e, cumprir um dos intentos críticos da proposta, presente nas migrações da obra original que, como tantas outras dispostas no espaço público, são removidas para zonas diversas da urbe, trancafiadas em depósitos ou mesmo destruídas, desobstruindo do corpo da cidade dos sinais que poderiam comprometer seu fluxo. Vale lembrar que a manutenção e preservação dos monumentos públicos é responsabilidade da SEMC/PMV. Desse modo, nesta distorção performativa reside um paradoxo que pode ser aproximado daquele que Vladmir Safatle apontou em relação aos processos de racionalidade e aos impasses originados e partilhados no âmbito das sociedades capitalistas contemporâneas. Para o autor "[...] mesmo o informe pode servir para sustentar uma ordem que vigora por meio de sua própria descrença" (SAFATLE, 2008, p.200)314.

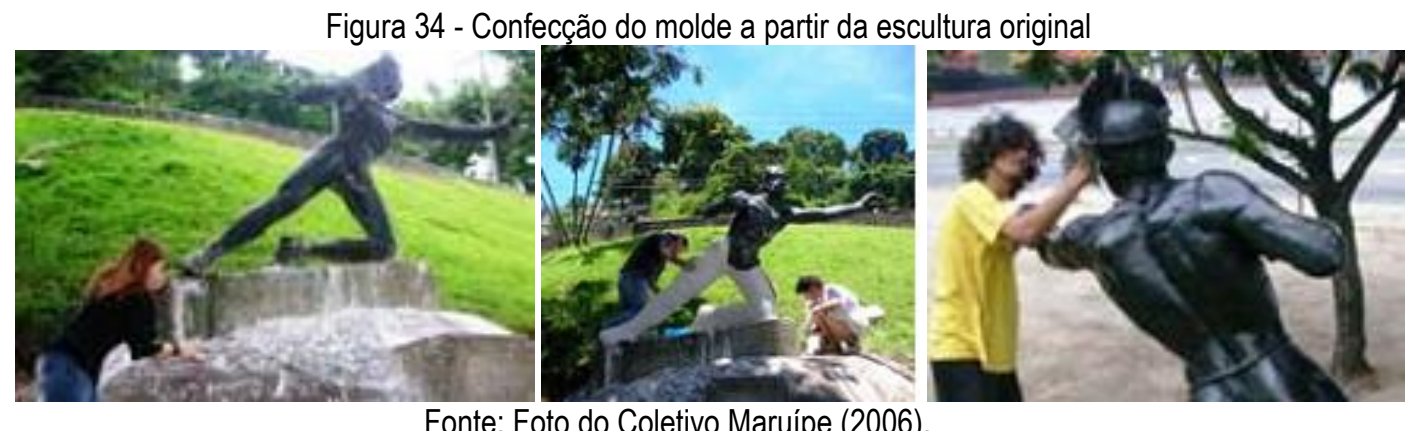

Fonte: Foto do Coletivo Maruípe (2006).

\footnotetext{
313 A data de inauguração da obra é incerta. Sabe-se, entretanto, que em 1963, ela foi reinstalada pelo então prefeito de Vitória, Solon Borges, em virtude da repercussão da marchinha carnavalesca (Bota o índio no lugar), de autoria de Júlio Alvarenga, premiada em um concurso da antiga TV Vitória. A marchinha "foi cantada à exaustão pelos foliões nas ruas e nos clubes da Capital, descontentes com a saída da estátua do índio da Beira Mar" (FARIA, Willis, 1992, p.27). Em 2012, por ocasião de uma restauração da obra, é mencionado que "Não localizamos documentos que comprovem a primitiva instalação da estátua do índio Araribóia, tampouco a data de sua inauguração, mas podemos afirmar que ela foi fundida em bronze na primeira metade da década de 1950, tendo sido instalada na Pedra Branca que originalmente era banhada pelo mar" (PREFEITURA MUNICIPAL DE VITÓRIA, Vitória: SEMC/PMV, 2012, s/p. Disponível em: <http://monumentoscapixabas.com.br/conteudo/uploads/2014/05/Arariboia.pdf>. Acesso em: 20 mai. 2017).

314 SAFATLE, Vladimir. Cinismo e falência da crítica. São Paulo: Boitempo, 2008.
} 


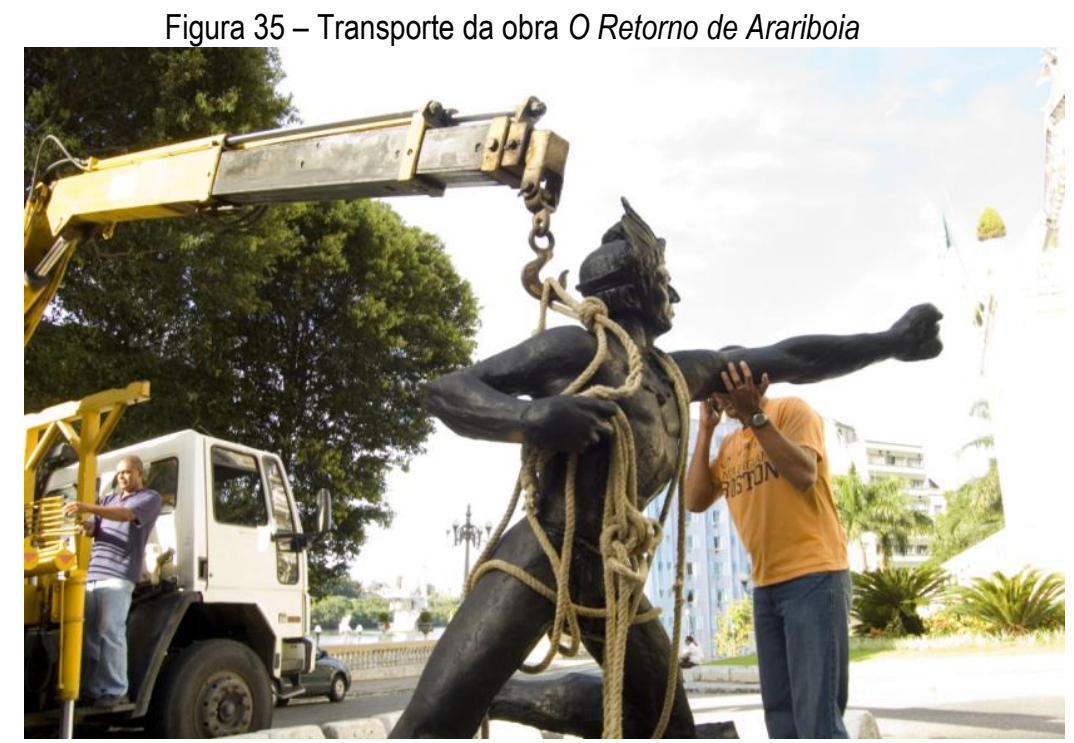

Fonte: Arquivo da autora. Foto: Raphael Araújo (2009).

Em uma cidade com a dimensão de Vitória, não é apenas o poder público que responde por sua dinâmica de funcionamento, empresas privadas são contratadas como prestadoras de serviço, ampliando assim a rede burocrática necessária para a inserção da arte no espaço público. Nesse sentido, a intervenção Folhetim Sereia, de Herbert Pablo e O Silêncio do Martelo, de Fabrício Carvalho servem de exemplo. Em Folhetim Sereia (Figs. 36 e 37), Herbert Pablo realizou decalques nos vidros dos abrigos para passageiros de ônibus, tratando segundo consta em seu projeto de "uma intervenção direta no corpo da cidade por meio de apropriações de imagens do circuito da arte contemporânea"315 (RUFINONI; MARGOTTO, 2009b, p.49). Inserção que, sem a anuência do poder público, seria eliminada e, se localizado seu autor, este seria notificado para realizar em 24 horas a remoção, vencido o prazo, receberia uma multa por ato infracional ${ }^{316}$. A permanência da obra durante o período do evento, portanto, só foi possível porque o artista cumpriu todos os protocolos burocráticos.

\footnotetext{
315 As referências utilizadas por Herbert Pablo foram Rebecca Horn, Marina Abramovic, Cindy Sherman, Orlan, Márcia X e Nan Goldin. Cabe lembrar, que na edição anterior do evento, o artista executou uma operação inversa, levando para o espaço expositivo imagens retiradas dos banheiros públicos.

316 Trata-se da Lei 5.086/2000, referente aos códigos de limpeza urbana. Em 2015, o valor da multa era R\$ 8.136,30. Disponível em: <http://www.vitoria.es.gov.br/noticia/prefeitura-fiscaliza-e-multa-quem-cola-cartazes-empontos-de-onibus-e-muros-17527>. Acesso em: 20 mai. 2017.
} 
Figura 36 - Herbert Pablo executando Folhetim Sereia

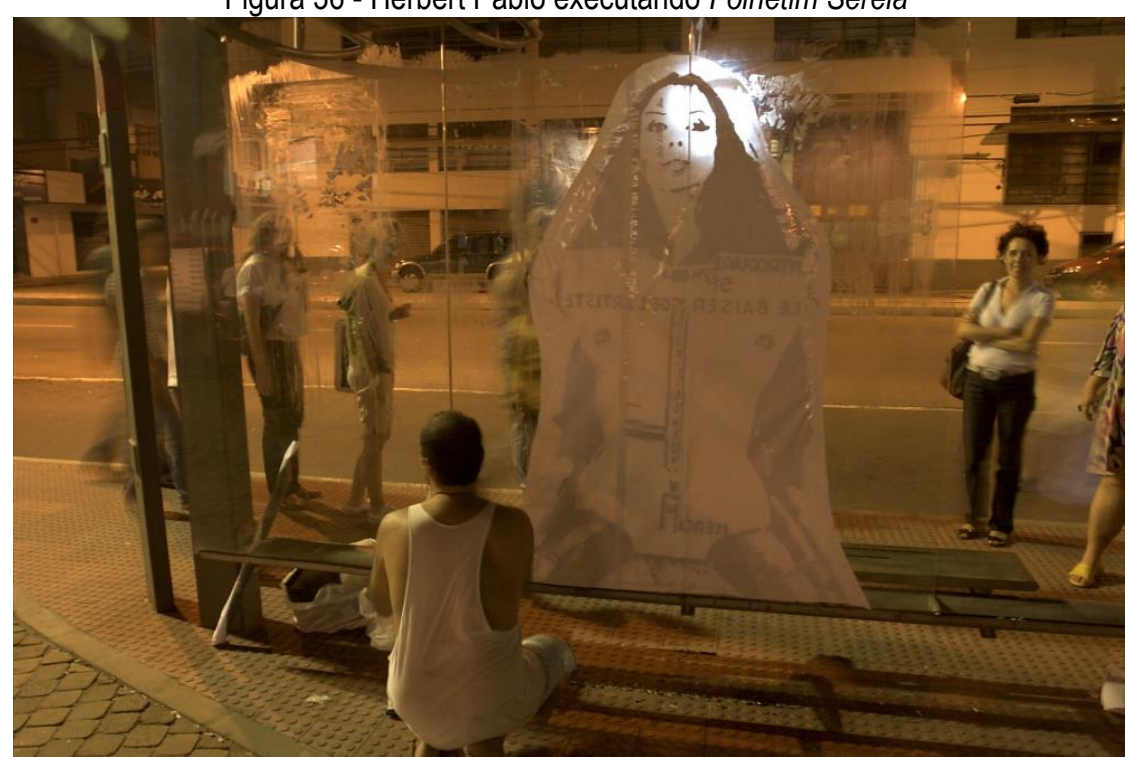

Fonte: Arquivo da autora. Foto:Gibran Chequer (2008).

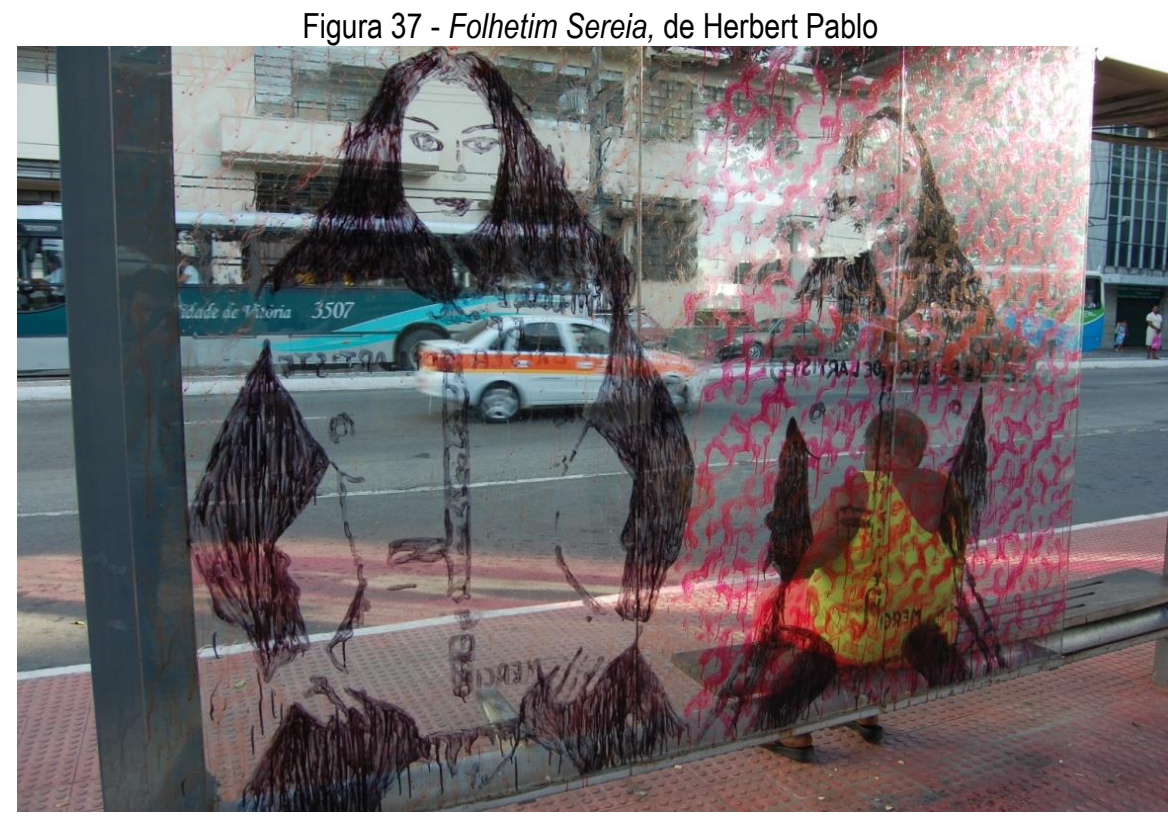

Fonte: Arquivo da autora. Foto: Raphael Araújo (2008).

O Silêncio do Martelo (Fig. 38), de Fabrício Carvalho, diversamente da intervenção de Herbert Pablo, permaneceu por pouquíssimo tempo nas ruas, já que o artista não realizou os trâmites burocráticos previstos. Assim, possivelmente o trabalho foi recolhido pela empresa terceirizada que presta serviço à PMV ${ }^{117}$. O efêmero "artístico, portanto, também não é da mesma ordem da volatilidade

$317 \quad$ No seu projeto o artista expõe que sua intenção era percorrer as ruas da cidade, "em direções aleatórias, afim de encontrar objetos que comumente os moradores abandonam nas ruas. Objetos domésticos, móveis, que fizeram parte de um ambiente íntimo e foram despejados num espaço público" (CARVALHO In: RUFINONI; MARGOTTO, 2009, p.37). Entretanto, conforme pôde ser aferido no registro fotográfico, em sua intervenção não constam objetos domésticos, portanto, a suposição que sua retirada foi realizada pela empresa que recolhe entulhos da cidade. Ressalta-se também que 
do espaço urbano que mimetiza", já que no caso da intervenção de Fabrício Carvalho "houve uma efemeridade 'real'” (RUFINONI; MARGOTTO, 2013, p.243).

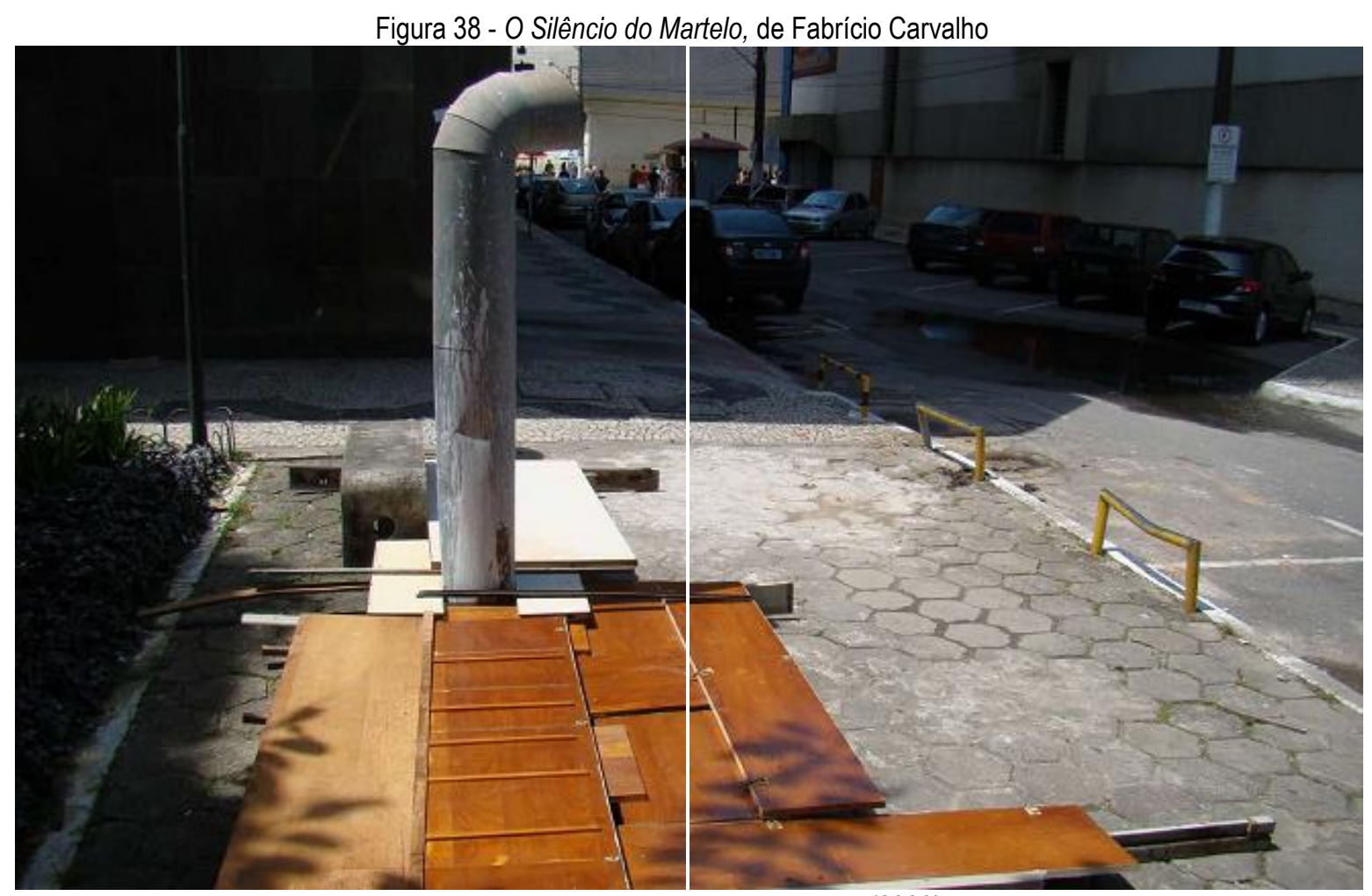

Fonte: Arquivo da autora. Foto: Bruna Tostes (2008).

\subsubsection{Leis, normas e obras}

O caráter aparentemente despojado trazido pelo espaço urbano esconde as amarras institucionais das quais, como visto no capítulo I, nem mesmo os coletivos artísticos conseguiram escapar. Típico de um processo de interdisciplinaridade movido de dentro para fora, em que os elementos estranhos são absorvidos e amenizados pela instituição, a autoridade imposta pela lei e seus órgãos reguladores constituem obstáculos que muitas vezes direcionam ou comprometem os resultados. Nesse sentido, ATENÇÃO: ARTE, de Jo Name, e grandePEQUENAcatraia, de Marcelo Gandini foram exemplos notórios no contexto do evento.

O projeto de Jo Name, intitulado ATENÇÃO: ARTE (Figs. 39 e 40), composto por vinte e seis placas de sinalização, procurava enfatizar "o oposto do que se espera de tais sinalizações: a regulamentação do uso do espaço público", conforme constatou Marilúcia Bottallo (In: RUFINONI; MARGOTTO, 2009b, p.65). No projeto encaminhado para a seleção, o artista sublinhou que sua

Fabrício Carvalho foi à sede da instituição para comunicar e entregar o registro de sua obra. Os fotógrafos contratados pelo evento estiveram no local indicado pelo artista pouco tempo depois, entretanto, a obra já não mais existia. 
intenção era apresentar "mensagens reveladoras do caos urbano", simulando a "organização oficial, mas, com mensagens visuais diferenciadas" e, que pretendia "provocar 0 estranhamento e até um tanto de repulsa como forma de chamar a atenção das pessoas para as diferentes camadas, às vezes marginais, de interação humana nas cidades" (NAME, 2008). Para conseguir as autorizações junto aos órgãos de trânsito, o projeto teve que ser reformulado. Ainda que a essência da proposta tenha permanecido, na nova versão advertências foram acrescentadas: "As placas [...] terão suas faces voltadas para o mar, sendo visíveis apenas aos pedestres que circularem junto à murada, sem interferir com a sinalização de trânsito" (grifo meu). Em outro trecho, a informação foi repetida, porém, em letras maiúsculas: "AS PLACAS SERÃO INSTALADAS DE MODO A NÃO INTERFERIR, DE NENHUM MODO, COM A SINALIZAÇÃO DE TRÂNSITO" (NAME, 2008). Diversamente do formato de losango das placas oficiais de advertência, propostas no projeto inicial, as do Jo Name tiveram que ser apresentadas em formato quadrado, com o dobro do tamanho das placas comuns e, conforme ele destacou, com coloração em um "tom de amarelo bastante diverso da cor padrão de sinalização de trânsito" (NAME, 2008).

Figura 39 - À esquerda a proposta de Jo Name e à direita a versão revisada
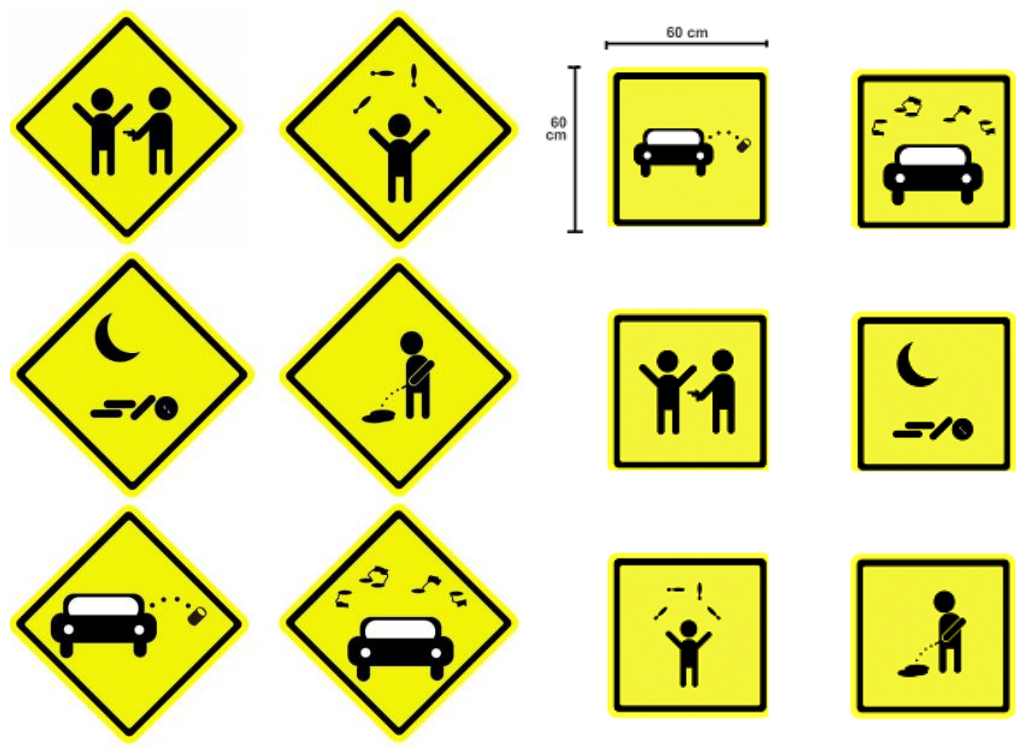

Fonte: Arquivo da autora (2008). 


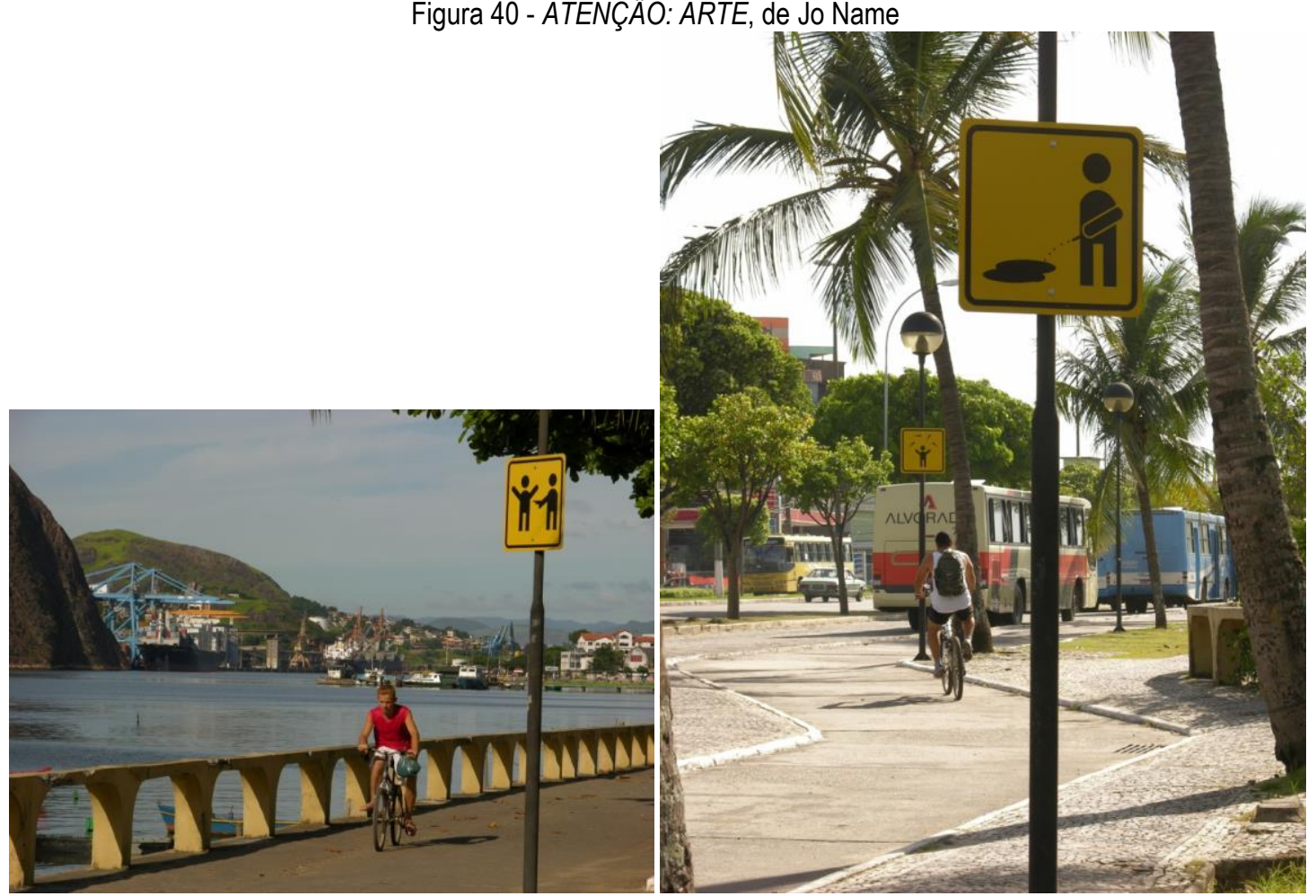

Figura 40 - ATENÇÃO: ARTE, de Jo Name

Fonte Arquivo da autora. Foto: Jo Name (2006).

Se as alterações exigidas pelos órgãos reguladores não chegaram a desfigurar por completo 0 projeto de Jo Name, no caso da obra grandePEQUENAcatraia (Fig. 41), de Marcelo Gandini, o mesmo não pode ser afirmado. A proposta desse artista consistia em contratar os serviços de um catraieiro318 para transportar uma caixa acústica que emularia a sinalização sonora das grandes embarcações, majoritariamente voltadas para atender às demandas do comércio exterior, criando um contraste com os diminutos barcos artesanais que transportavam passageiros entre os municípios de Vitória e Vila Velha. Segundo consta em seu projeto, 0 objetivo principal era "atrair 0 olhar do espectador/transeunte", pois, ao voltar-se para o mar, o mesmo não encontraria a imagem grandiloquente dos navios cargueiros, mas uma pequena embarcação. Tão reduzido quanto o tamanho das catraias foi o volume sonoro autorizado para ser emitido, portanto o deslocamento sensorial sugerido não se efetivou senão no âmbito da metáfora. Cabe ressaltar que as regras de sinalização sonora e luminosa, com o fito de evitar abalroamentos no mar, são normas internacionais que 0 artista, possivelmente, desconhecia. A distância entre o intuito poético e as limitações legais não eliminam 0

\footnotetext{
$318 \quad 0$ catraieiro é um tripulante de uma embarcação de pequeno porte movida a remo. Eles eram figuras tradicionais na paisagem marítima capixaba, entretanto, desde 2015, por meio de um acordo entre a Associação dos Catraieiros da Baía de Vitória e a CODESA, a atividade foi suspensa. Primeiro, de forma provisória, sob a alegação que as obras de dragagem colocariam em risco os passageiros e profissionais, depois, um novo acordo extinguiu definitivamente o serviço. Cabe lembrar que o argumento utilizado (segurança e proteção) repetiu aquele que, na década de 1940, bloqueou o acesso ao porto pela população. Disponível em: <http://vitorianews.com.br/geral/noticia/2016/01/catraieiros-de-vitoria-fazem-acordocom-a-codesa-e-nao-voltam-mais-a-fazer-transporte-de-passageiros-68789.html>. Acesso em: 20 mai. 2017.
} 
caráter político do debate proposto. Marilúcia Bottallo analisou as sugestões contidas na proposta evocando uma série de binômios: "grandes navios comerciais x pequenas catraias de transporte da população local; modernidade x tradição; mudança x permanência; local - como utopia x global - como perda...". Em momento posterior, ela questionou: "o catraieiro é paisagem reminiscente, memória, cultura ou ainda haverá espaço possível para tais personagens 'invisíveis'?" (In: RUFINONI; MARGOTTO, 2009b, p.64). A extinção da profissão, poucos anos depois, não deixa dúvidas da resposta à indagação lançada, tampouco do que acaba por prevalecer nos contrastes expostos entre os termos contrapostos. Em nome do progresso econômico é necessário desobstruir tudo o que possa impedir seu fluxo, seja por afronte ou morosidade.

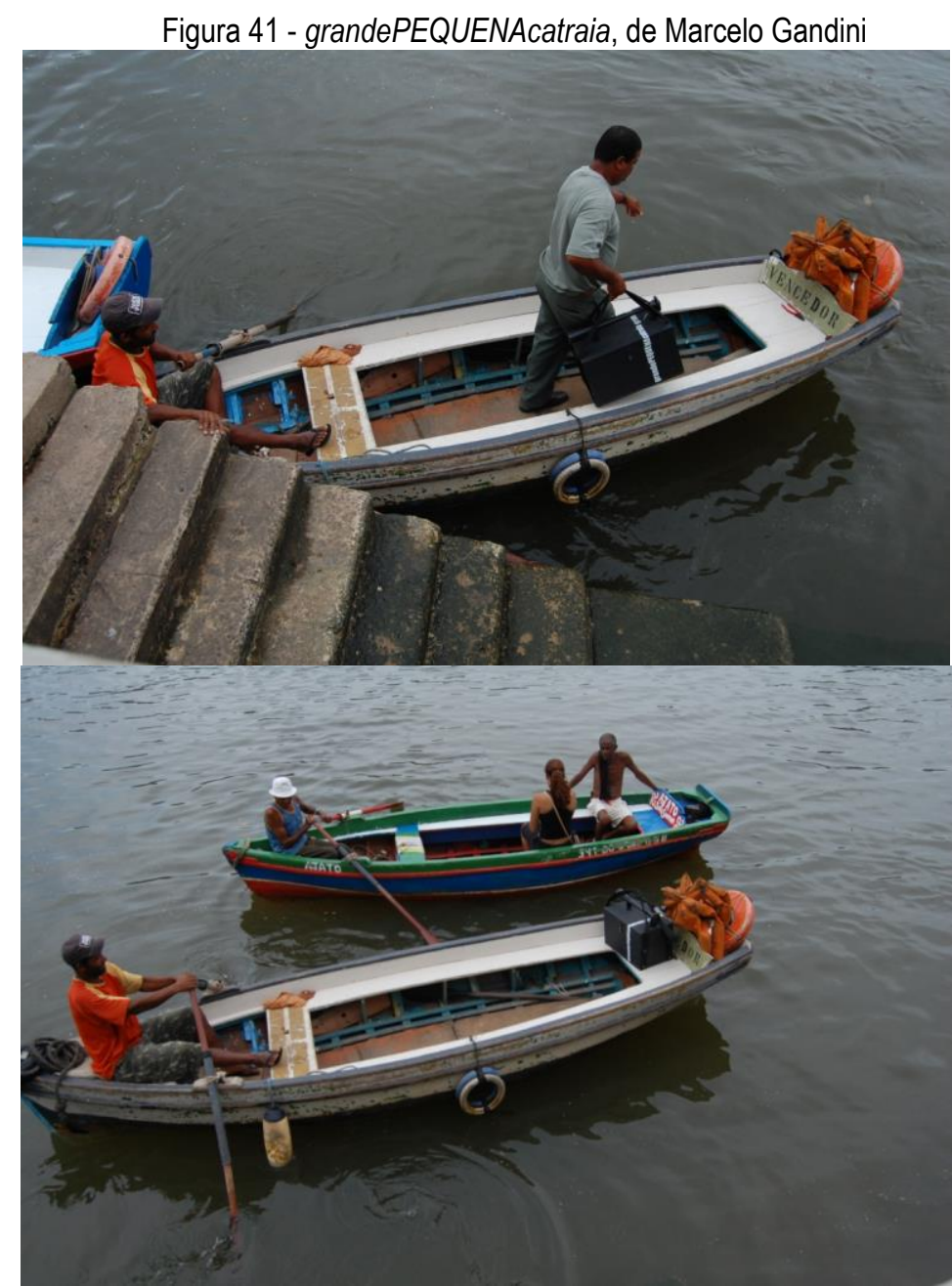

Fonte: Arquivo da autora. Foto: Raphael Araújo (2008). 


\subsubsection{Disciplina: fluxos e suportes}

O desejo em participar dos movimentos da vida contemporânea, isto é, realizar uma atualização das práticas também constituía em outra faceta de variação do processo disciplinar. 0 boom das cidades, promovido pelos conceitos de cidade global e reabilitação urbana de base cultural, apoiou o novo apelo ao espaço urbano, lugar em que todos estariam ou passariam, do qual eventos artísticos tomaram parte. Neste sentido, as ruas figuraram como dispositivo ao movimento de espetacularização da arte, já que poderiam potencializar uma visibilidade em números inéditos dos obtidos pelos espaços tradicionais. Porém, a atualização do Salão do Mar não atingiu o novo espaço público do século XXI, no qual aquela quantidade de audiência poderia ser alcançada. À época, 2008, blogs, fóruns, web sites de streams, dentre outras plataformas lícitas - para os ativistas de fato, sempre existem as possibilidades ilícitas, como pichação de sites públicos, negação de servidores etc. -, estavam acessíveis, mas a aspiração de atualização encerrava-se com a viabilidade estrutural disponível à instituição, uma vez que esta possibilidade demandaria outra direção para a produção do evento. Todavia, alguns artistas selecionados na $8^{a}$ edição, fizeram uso do espaço virtual, ainda que este recurso tenha sido adotado mais como registro ou consulta do que como espaço de debate e participação pública que poderiam interferir efetivamente no processo dos trabalhos. No Madrid Abierto de 2007, por exemplo, três obras exibidas na primeira edição em 2004 foram tomadas como referência, uma delas foi Virtual Demolition Mobile, do coletivo El Perro ${ }^{319}$. Nesta, os espaços virtual e físico se intercambiavam. A proposta do coletivo consistiu em disponibilizar na Web um canal de votação (para a convocação, eles encaminharam e-mails), no qual, era possível o participante escolher dentre os edifícios públicos sugeridos ou outros que gostaria de ver em chamas, bem como data e horário do feito. Prédios que representavam hierarquias e símbolos de poder das estruturas econômicas, financeiras, políticas ou militares foram mencionados e demolições foram projetadas sobre aqueles democraticamente eleitos (FERNÁNDEZ, 2012, p.95-96) ${ }^{320 .}$

Herbert Pablo, em Folhetim Sereia, utilizou tanto o espaço físico quanto virtual, desenvolvendo de forma circular a noção de registro. As imagens das artistas Rebecca Horn, Marina Abramovic, Cindy Sherman, Orlan, Márcia X e Nan Goldin decalcadas nos vidros dos pontos de ônibus eram parte de sua

319 Cf: FERNÁNDEZ, Maria Dolores Arroyo. Arte en la calle: Evolución del concurso internacional Madrid Abierto en el periodo 2004-2007. Arte y Ciudad - Revista de Investigación. № 2, Octubre de 2012, pp.95 e 96. Disponível em: <http://arteyciudad.com/revista/index.php/num1/article/view/74/129>. Acesso em: 20 mai. 2017. Ver também o site do coletivo: $<$ http://www.democracia.com.es/proyectos/virtual-demolition-mobile/>. Acesso em: 20 mai. 2017.

320 Cf: FERNÁNDEZ, Maria Dolores Arroyo. Arte en la calle: Evolución del concurso internacional Madrid Abierto en el periodo 2004-2007. Arte y Ciudad - Revista de Investigación. № 2, Octubre de 2012, pp.95 e 96 . Disponível em: <http://arteyciudad.com/revista/index.php/num1/article/view/74/129>. Acesso em: 20 mai. 2017. Ver também o site do coletivo: <http://www.democracia.com.es/proyectos/virtual-demolition-mobile/>. Acesso em: 20 mai. 2017. 
coleção captada na internet. A intervenção nas ruas possuía um espelho no site www.folhetimsereia.com ${ }^{321}$. Neste, sua intenção era postar semanalmente, "na mesma frequência de circulação dos antigos folhetins", minivídeos captados de uma câmera digital e do seu celular das intervenções efetuadas, devolvendo à interface digital o que dela foi retirado. Folhetim Sereia também dialogou com as "estratégias de ocupação das ruas pelos artistas que escolheram a cidade como seu suporte de expressão" (In: RUFINONI; MARGOTTO, 2009b, p.49-51), integrando algumas posturas peculiares desses, como as tags (Fig. 42).

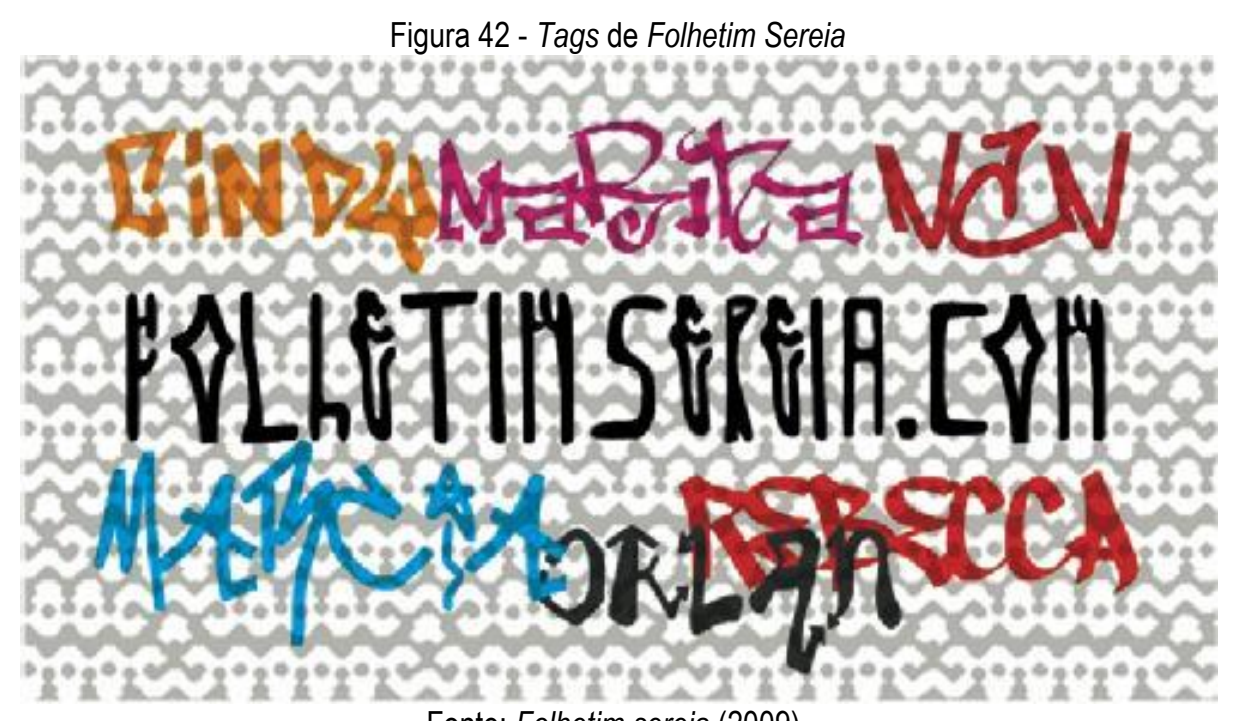

Fonte: Folhetim sereia (2009).

O projeto Marí(n)timo (Fig. 43), de Melina Almada, também previa a utilização da internet. Sua proposta foi dispor livros com a temática marítima em estações (Fig. 37) localizadas em pontos de ônibus na Avenida Beira-Mar. Em sua primeira postagem no site www.marintimomar.blogspot.com, em quatro de novembro de 2008, a artista solicitava doações de obras para integrarem as minibibliotecas públicas, sublinhando que bastaria o interessado entrar em contato via e-mail ou por telefone que, a retirada seria por ela efetuada. Além disso, constaria no site, junto à listagem dos livros, seus respectivos concessores. Em vinte e seis de dezembro, a relação das obras e dos autores disponibilizadas nas seis caixas foi postada ${ }^{322}$, entretanto, não há menção aos doadores, levando a supor que 0 acervo não foi constituído por donativos. 0 site tinha também por função que os usuários

\footnotetext{
$321 \quad 0$ site não está mais disponível, entretanto, o fotolog com uma espécie de diário da instalação, divulgação e desenvolvimento da ação, ainda está ativo. Disponivel em: <www.fotolog.com/folhetimsereia>. Acesso em: 10 fev. 2018.

322 A sistematização entre a localização e a quantidade de títulos teve como referência as informações que constam no site do projeto. Caixa 1 - Defronte ao Colégio Salesiano (17); Caixa 2 - DER-ES, Departamento de Estradas de Rodagem do Estado do Espírito Santo (19); Caixa 3 - Defronte à sede da PMV - em frente ao CNRAC - Clube de Natação e Regatas Álvares Cabral (19); Caixa 4 - Instituto Luiz Braille do Espírito Santo (21); Caixa 5 - Catraieiros (16); Caixa 6 Em frente à Primeira Igreja Batista de Vitoria (20). Disponível em: <http://marintimomar.blogspot.com.br/2008/>. Acesso em: 20 mai. 2017.
} 
conferissem os títulos existentes e as atualizações, entretanto, não foi explicitado como isso ocorreria (Fig. 43, item 6).

Figura 43 - Marí(n)timo, de Melina Almada. No detalhe o manual

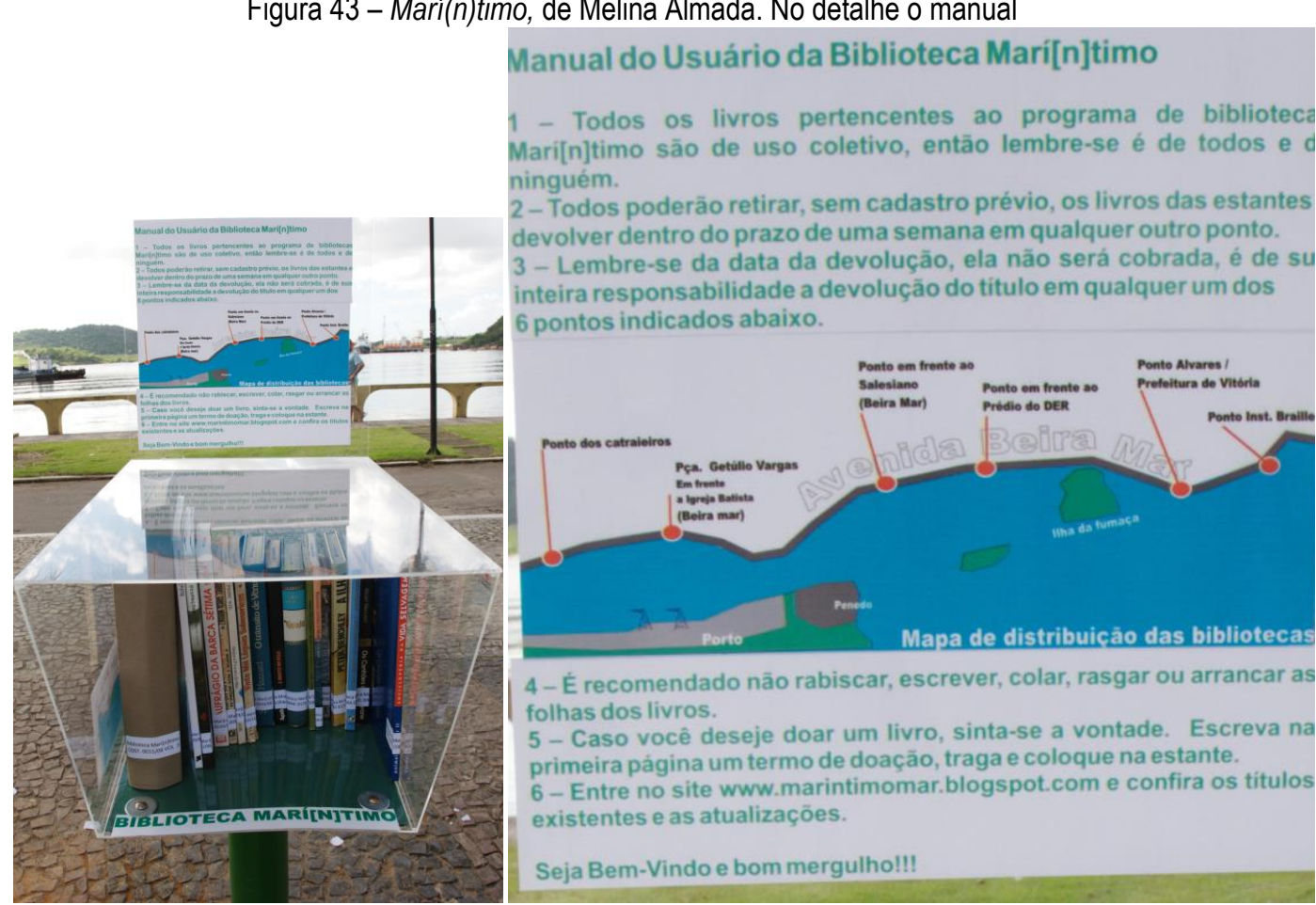

Fonte: Arquivo da autora. Foto: Gibran Chequer (2008).

Apesar de emular os serviços prestados por bibliotecas efetivas, a proposta das minibibliotecas de Marí[n]timo (Fig. 44) era não fiscalizar o retorno dos livros, entretanto, no Manual do Usuário... 0 prazo estipulado para a devolução era restrito a uma semana. Tal sentença pressupunha, portanto, um leitor voraz, capaz de degustar "Trabalhadores do Mar" de Victor Hugo ou os livros "HMS Ulysses" e "Os Canhões de Navarone", ambos de Alistair MacLeann (obras mencionadas na listagem das caixas), no reduzido período ordenado. Foi recomendado aos usuários "não rabiscar, escrever, colar, rasgar ou arrancar as folhas dos livros (Fig. 43, item 4), sentença que pretendia circunscrever a participação ao ato de ler. 


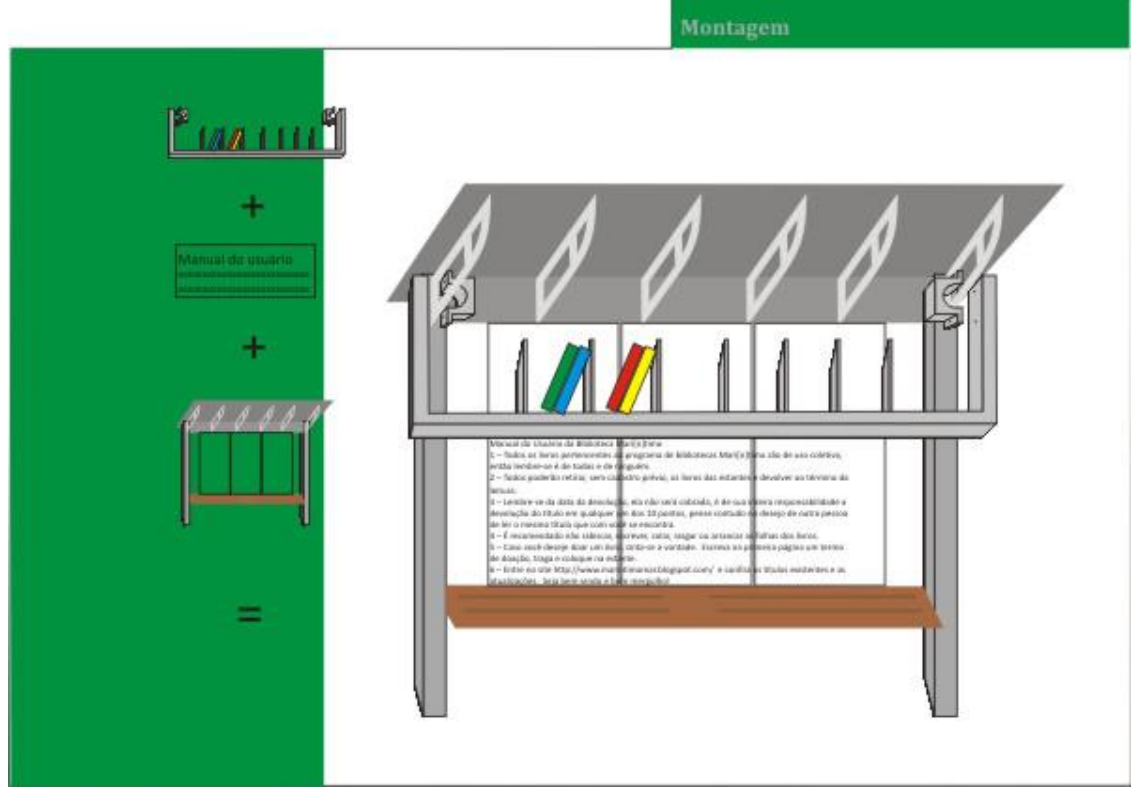

Fonte: Arquivo da autora (2008).

Como componente final às questões disciplinares envolvendo a utilização do espaço urbano, deve-se salientar a instrumentalização dos aspectos estranhos à disciplina artística de dentro para fora. Nesse processo de incorporação, em que o externo é agregado e acomodado de acordo com as leis vigentes, o espaço público pode ser encarado como uma expansão espacial do salão. Não é qualquer espaço de Vitória que poderia ser usado, nem mesmo os espaços permitidos poderiam ser utilizados de qualquer modo: o espaço urbano é, literalmente, um salão com metros quadrados ampliados e não uma savana real. $\mathrm{O}$ que resta do urbano subsiste como obstáculo a ser amenizado pela produção e pelo projeto artístico, cujo escopo muitas vezes é do nível da metáfora, tal como o seria em um suporte tradicional. É nesse cenário controlado que o efeito crítico de contestação pode ser esmaecido. Resta, portanto, aos empreendimentos institucionalizados, a crítica indireta, enviesada, "simbólica", irônica, únicas possibilidades de afrontamento sem a punição certa da autoridade.

Das propostas selecionadas, algumas são flexíveis quanto à natureza do local de exposição. Líquidas Fronteiras, de Lucimar Bello, Do pó ao pó, de Laerte Ramos, Ego trip pré-sal, de João Wesley e Sandro Souza, são reflexões sobre cidades, mas não necessariamente carecem do ambiente das ruas para haver-se. Na maioria dos projetos, porém, a utilização do espaço urbano para sua configuração é imprescindível, exemplo disso são as obras: Caminho das Águas, de Piatan Lube, 0 retorno de Araribóia, do Coletivo Maruípe, O Silêncio do Martelo, de Fabrício Carvalho, grandePEQUENAcatraia, de Marcelo Gandini, Folhetim Sereia, de Herbert Pablo, Atenção : Arte, de Jo Name, Marí(n)timo, de Melina Almada, Plus Ultra, 2007 - ..., de Oriana Duarte e, Nós vemos a cidade 
como a cidade nos vê, de Heraldo Ferreira. Tanto Plus Ultra, 2007 - ... (Figs. 45 e 46), de Oriana Duarte quanto Nós vemos a cidade como a cidade nos vê (Figs. 47 e 48), de Heraldo Ferreira evocam realidade e virtualidade e, a relação corpo e paisagem para examinar aspectos dicotômicos da urbe. Oriana usa seu próprio corpo como suporte para remar em águas urbanas, normalmente poluídas, desvelando "outra 'realidade', que nos introduz as complexidades da nossa contemporaneidade" (In: RUFINONI; MARGOTTO, 2009b, p.86): objetos, fezes, corpos de animais mortos foram dejetos dos quais a artista teve que se desvencilhar em suas travessias. Enquanto, Heraldo Ferreira criou conexões entre a imagem da cidade e o que definiu como "espectador-modelo-espectador", por meio de infinitos reflexos possíveis de serem visualizados quando se adentra no conjunto de quatro espelhos colados em estruturas de madeira pintadas de branco, dispostos na Praça Pio XII.

Figura 45 - Plus Ultra, 2007 -..., de Oriana Duarte

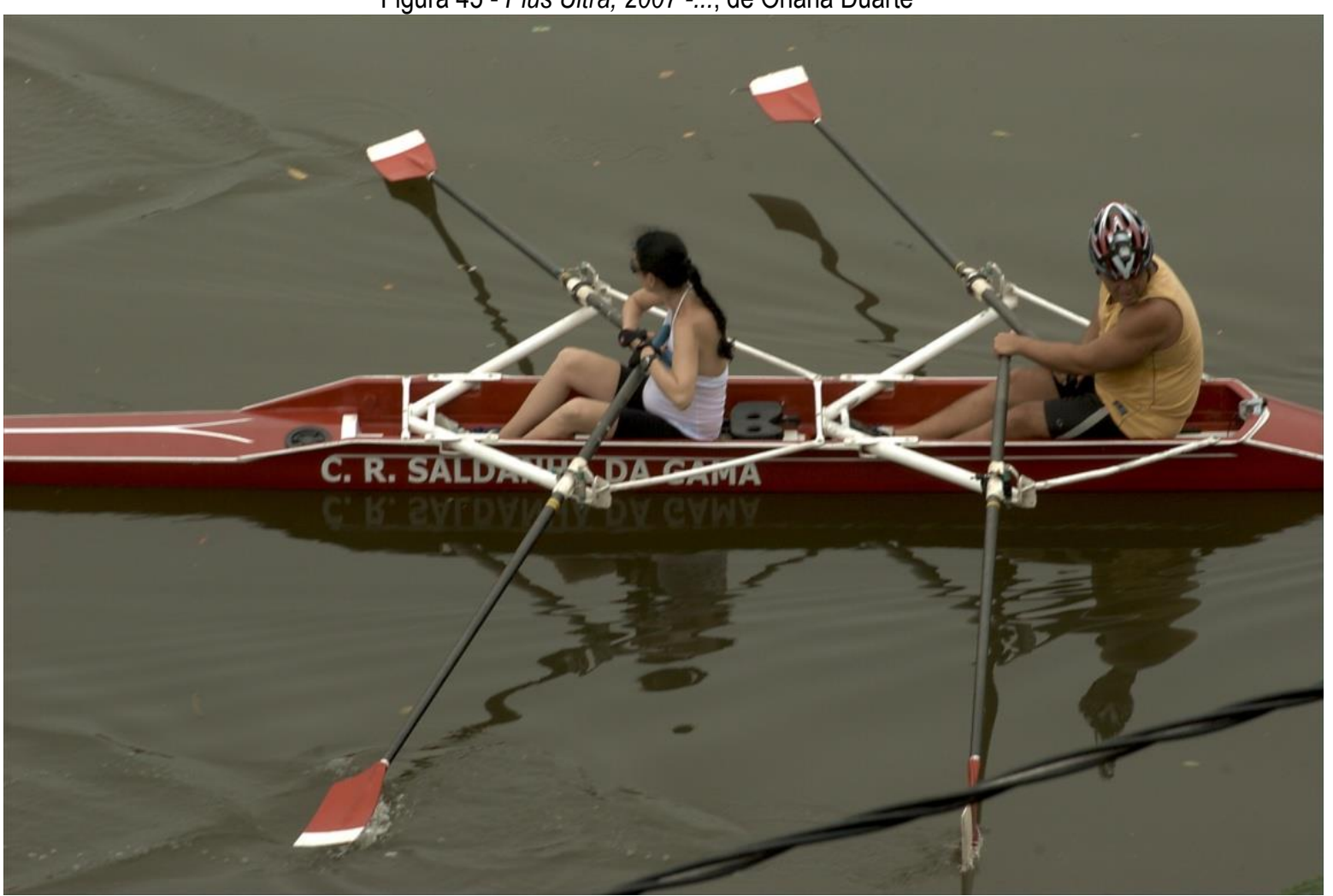

Fonte: Arquivo da autora. Foto: Gibran Chequer (2008). 
Figura 46 - Plus Ultra, 2007 -..., de Oriana Duarte

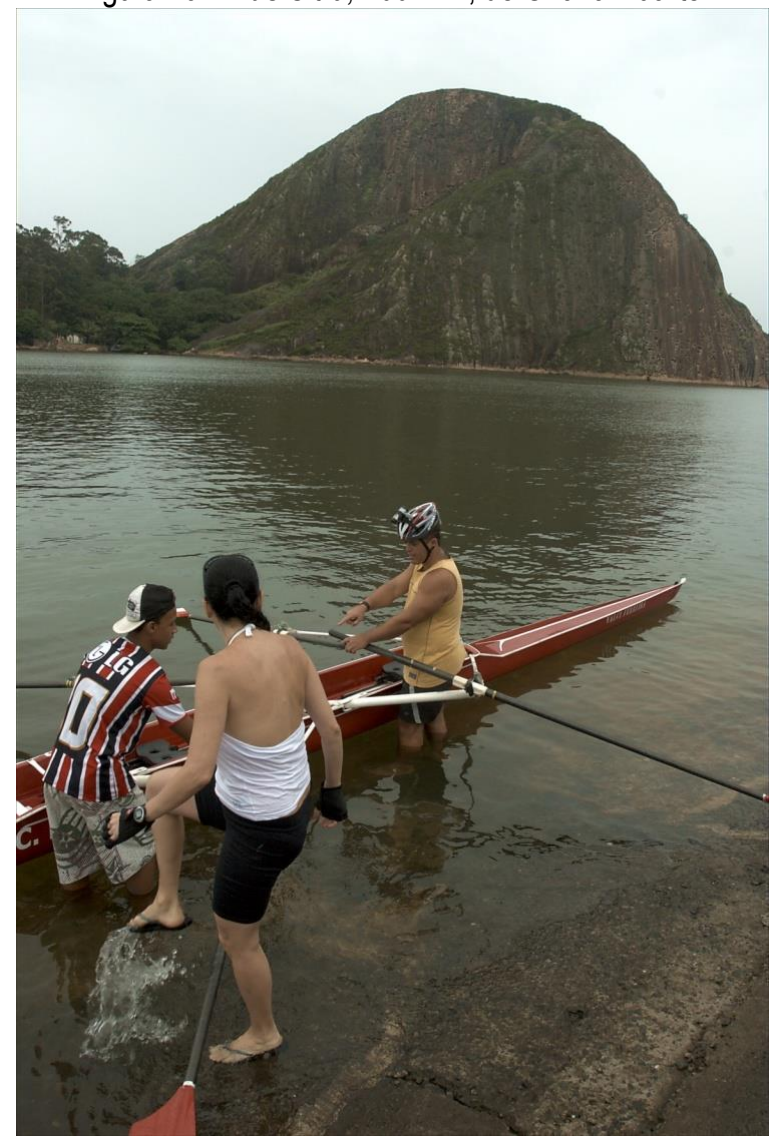

Fonte: Arquivo da autora. Foto: Gibran Chequer (2008).

Figura 47 - Nós vemos a cidade como a cidade nos vê, de Heraldo Ferreira

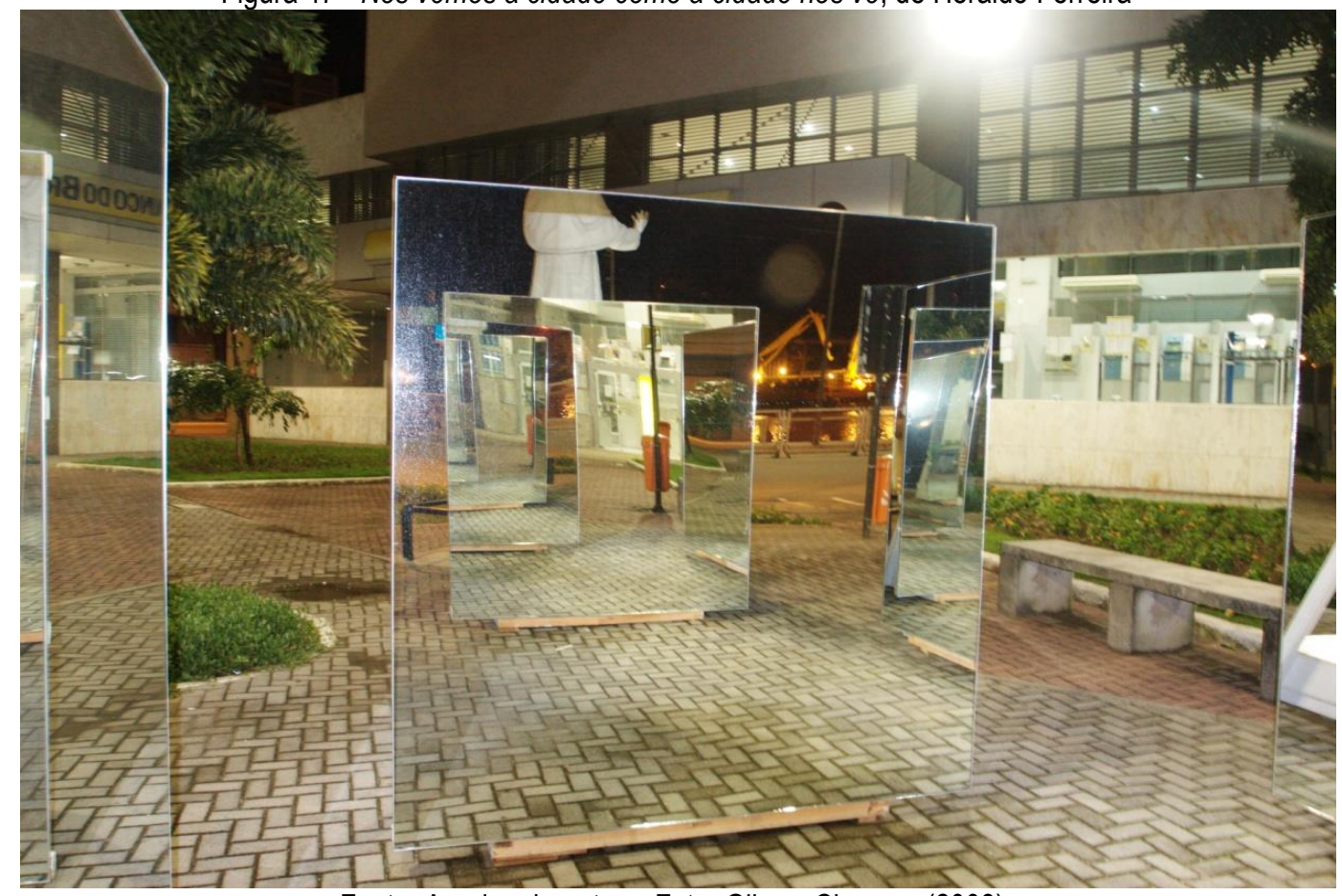

Fonte: Arquivo da autora. Foto: Gibran Chequer (2008). 
Figura 48 - Imagem do projeto de Heraldo Ferreira

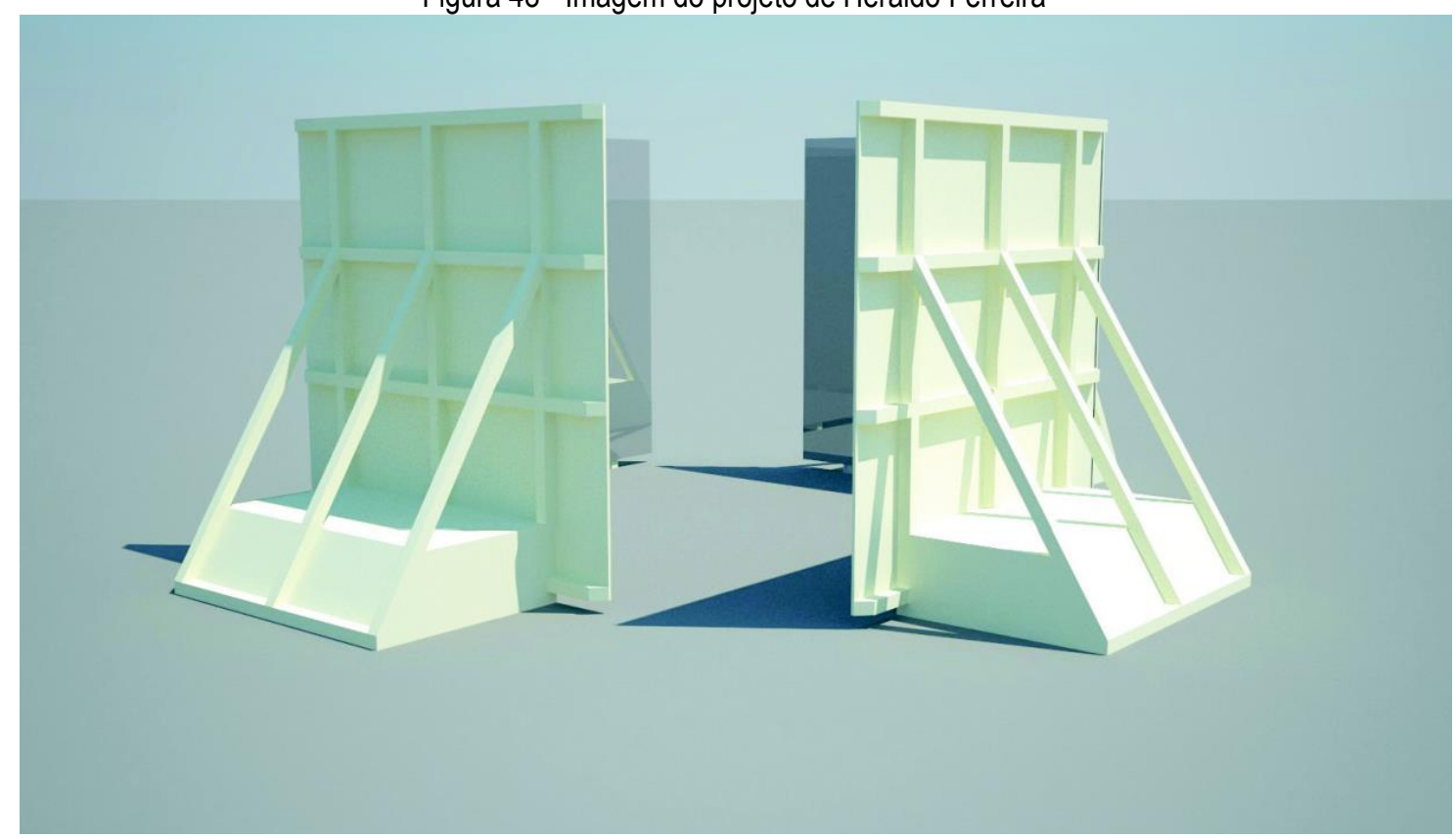

Fonte: Arquivo da autora (2008).

Se não necessariamente o espaço público era imprescindível como plataforma expositiva para alguns trabalhos apresentados, também a noção da relação mais "democrática" entre 0 artista e 0 espectador, presente nos discursos que visavam reformular seu papel mais tradicional, foi pouco evocada. A noção de coautoria - conforme referenciada no capítulo dedicado aos coletivos - não foi salientada por nenhum dos selecionados e o entendimento de participação, quando utilizado, perpassou muito mais pela aproximação com algumas categorias profissionais ${ }^{323}$. Oriana Duarte necessitou da infraestrutura e da cooperação de membros de um clube de remo; a réplica do monumento ao índio do Coletivo Maruípe foi executada pelo escultor Jânio Leonardelli, Piatan Lube contou com o auxílio de cerca de quatorze pessoas para a execução em três dias de sua pintura monumental (RUFINONI; MARGOTTO, 2009b, p.33) e Marcelo Gandini contratou os serviços dos catraieiros.

De forma mais proeminente, a participação do transeunte, sem ser na condição de espectador, foi proposta por Melina Almada e Fabrício Carvalho, porém, em ambos os casos, essa interface com o

323 Em Delegated Performance: Outsourcing Authenticity, Claire Bishop traçou uma tipologia provisória para abordar uma ruptura na tradição da performance (que antes era realizada pelo próprio artista e valorizava a presença e 0 imediatismo ao vivo), iniciada após 1989 e que no começo da década de 1990, passou a ter como característica a terceirização do trabalho. Um dos exemplos mencionados é o artista Maurizio Cattelan, que em 1991, montou um time de futebol com imigrantes do norte da África para jogar na Itália, estampando em alemão nas camisas do time o nome de um patrocinador fictício, que pode ser traduzido como "Fora estrangeiros". BISHOP, Claire. Artificial Hells: Participatory Art and the Politics of Spectatorship. London/ New York: Verso, 2012, p.220 e 221. 
público das ruas apresentou-se na forma de "sites vazios" - termo utilizado por Miwon Kwon ${ }^{324}$ - logo após suas respectivas inserções no tecido urbano. Melina Almada foi a única que utilizou o usuário do transporte coletivo como componente ativo de obra, entretanto, as recomendações sobre as formas de participação e a imposição em relação ao prazo de devolução, em vez de desativar a relação hierárquica tradicional da disciplina acabou por potencializá-la. Na chamada para a seleção dos projetos, o objeto proposto pelos organizadores era dedicado a práticas artísticas que estabelecessem uma relação interdisciplinar com a cidade, seus espaços e habitantes. Se a conexão mencionada foi proposta aos artistas, para o exame sobre sua recepção foi contratada uma equipe de profissionais em quantidade muito superior a qualquer outra das edições anteriores do evento. Salvo engano, talvez tenha sido essa a única tentativa, em Vitória, de avaliar a recepção do público para obras dispostas no espaço urbano.

\title{
3.1.5 Um grande laboratório: interfaces com o múltiplo
}

\begin{abstract}
Todo o confuso amontoado do social se move em torno desse referente esponjoso, dessa realidade ao mesmo tempo opaca e translúcida, desse nada: as massas. Bola de cristal das estatísticas, elas são "atravessadas por correntes e fluxos", à semelhança da matéria e dos elementos naturais. Pelo menos é assim que elas nos são representadas (Jean Baudrillard) ${ }^{325}$.
\end{abstract}

"Como propor uma ação educativa dentro de uma bienal de intervenção urbana?". Esta indagação, que intitula um texto ${ }^{326}$ assinado pelos responsáveis pela coordenação operacional e pedagógica da ação educativa do $8^{\circ}$ Salão Bienal do Mar, Erly Vieira Júnior e Célia Ribeiro, anuncia as dúvidas que perpassaram a concepção da proposta de mediação, designada por eles, como um grande laboratório, no qual, uma série de ações foi testada durante o mês de janeiro de 2009 (VIEIRA JÚNIOR; RIBEIRO, 2009, s/p).

Ao elencarem alguns aspectos que exigiam uma abordagem diferenciada daquela praticada dentro dos espaços tradicionais, os autores destacaram três pontos interligados. 0 primeiro coloca em questão o fato que o contato do público do espaço urbano com a obra não era resultado de uma escolha, mas do acaso, sublinhando a diferença entre as intervenções em locais de passagem (com duração de segundos) daquelas dispostas, por exemplo, em abrigos de ônibus ou praças públicas. No

\footnotetext{
324 Cf.: Sitings of public art: integration versus intervention, terceiro capitulo do livro One place after another: sitespecific art and locational identity.

325 BAUDRILLARD, Jean. À sombra das maiorias silenciosas: 0 fim do social e o surgimento das massas. Tradução de Suely Bastos. São Paulo: Editora Brasiliense, 1985, p.5.

326 CIRILLO, José Aparecido; MENDES, Neusa (Org.). Atenção arte: doze obras efêmeras e uma permanente (Obra não publicada, organizada em 2009a).
} 
segundo ponto, eles questionam como poderiam transmitir informações sobre obra e artista, considerando o tempo exíguo de contato com esse público em trânsito. No último, expõem as dificuldades em adotar metodologias anteriores como referência ${ }^{327}$, sublinhando, por fim, que o método escolhido foi composto por uma série de ações que eram diariamente testadas.

[...] A cada dia o grupo concebia, experimentava, registrava [...] novas estratégias de abordagem, muitas vezes específicas a cada obra, seguindo-se uma avaliação diária de cada ação, de modo a ser possivel uma comparação de resultados (VIEIRA JÚNIOR; RIBEIRO, 2009, s/p).

Algumas das ações desenvolvidas permitiram sondar a opinião do público de forma diversa dos questionários e entrevistas mais convencionais. A abordagem que teve como referência o Teatro Invisível, concebido e praticado por Augusto Boal, foi uma delas ${ }^{328}$. A interpelação do público por essa modalidade foi realizada em Folhetim Sereia, de Herbert Pablo (Fig. 49), Marí(n)timo, de Melina Almada e Atenção: Arte, de Jo Name, nos dias 13 e 15 de janeiro de 2009.

\footnotetext{
$327 \quad$ Nas palavras dos autores: "[...] as poucas ações já realizadas no Brasil para mediação de exposições de intervenção urbana de grande porte (como a Bienal do MERCOSUL, por exemplo) não forneciam parâmetros suficientes para que pudéssemos aproveitar alguma metodologia já existente (o que se agravava pelo fato de que nunca havia ocorrido um evento dessa natureza no Espírito Santo)". VIEIRA JÚNIOR, Erly; RIBEIRO, Célia. Como propor uma ação educativa dentro de uma bienal de intervenção urbana? In: CIRILLO, José Aparecido; MENDES, Neusa (Org.). Atenção arte: doze obras efêmeras e uma permanente. Vitória, 2009a, s/p.

328 O Teatro Invisível "[...] consiste em se preparar uma cena, para apresentar em um espaço de acesso público, sem que ninguém, exceto os atores, venha a saber que se trata de uma encenação" (BALESTRERI, 2013, p.3). BALESTRERI, Silvia. Verdade e ética no teatro invisível. Anais do Simpósio da International Brecht Society, vol.1, 2013. Disponível em: $<$ https://www.ufrgs.br/ppgac/wp-content/uploads/2013/10/Verdade-e-\%C3\%A9tica-no-Teatro-Invis\%C3\%ADvel.pdf>. Acesso em: 14 dez. 2016.
} 

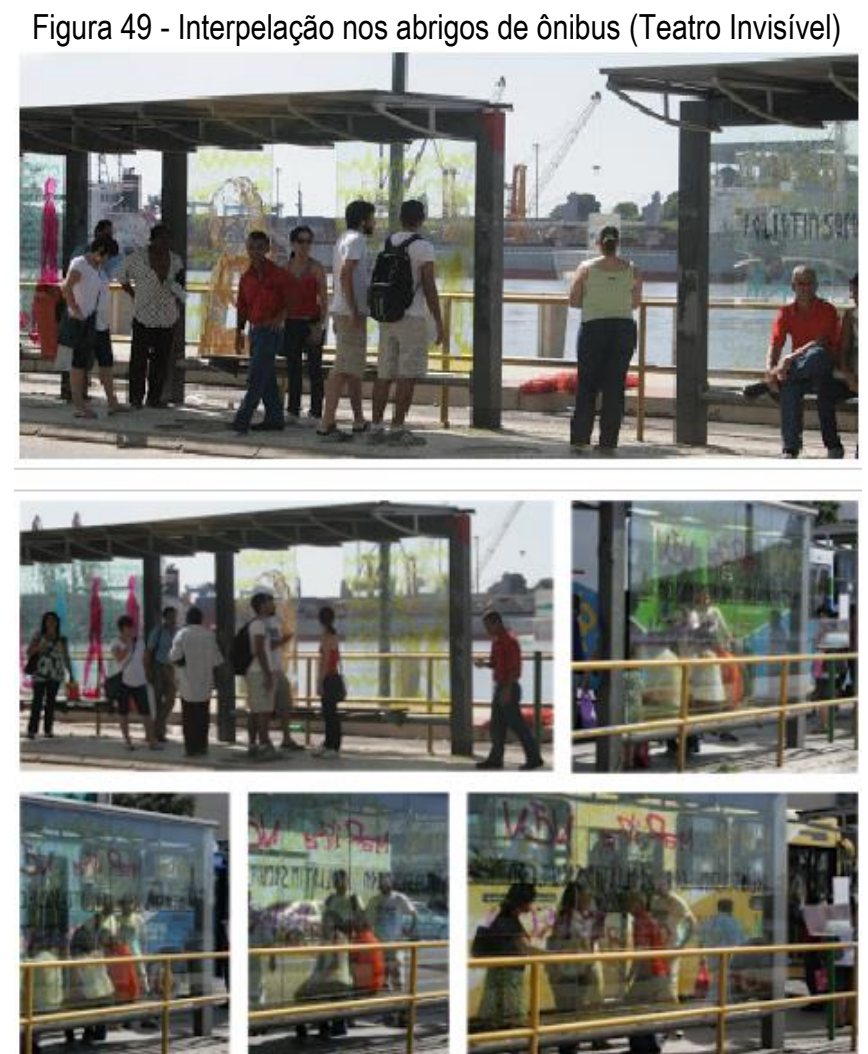

Fonte: Foto:Giovanna Faustini (arteducelialice, 2009).

A ousadia da proposta tinha como limite o fato de os mediadores não possuírem formação em Teatro (eram estudantes de Comunicação, Artes Visuais e Design). Uma das vinte pessoas que respondeu às encenações provocativas, empreendidas no abrigo de ônibus com a intervenção Folhetim Sereia, acabou por concluir que dois dos mediadores eram os "autores deste ato de vandalismo" 329 . Outras estratégias foram utilizadas ${ }^{330}$, porém, aquelas menos convencionais foram sendo mescladas e, por fim substituídas por outras com intuito mais informativo. A divulgação do evento "junto aos anônimos formadores de opinião" e a distribuição de folders tanto na área do evento quanto na orla de Camburi exemplificam a afirmação. Considerando os dados sistematizados pela equipe da Ação Educativa e as informações contidas nos e-mails trocados entre seus membros ${ }^{331}$, dos trabalhos apresentados no $8^{\circ}$ Salão Bienal do Mar, em apenas seis foi possível uma intermediação

329 É possível supor que o interesse dos mediadores pela obra tenha despertado desconfiança. A frase mencionada pode ser conferida no seguinte site. Disponível em: <http://arteducelialice.blogspot.com.br/>. Acesso em: 16 set. 2017.

$330 \quad$ As estratégias estão descritas e exemplificadas no blog de Célia Ribeiro, são elas: 1. Teatro Invisível; 2. Performance - Encenações sobre O Caminho das Águas; 3. Incursões urbanas provocativas; 4. Registros fotográficos e depoimentos em vídeo; 5. Divulgação junto aos anônimos formadores de opinião; 6. Panfletagem; 7. Oficinas para a comunidade. Disponível em: <http://arteducelialice.blogspot.com.br/>. Acesso em: 16 set. 2017.

331 Os e-mails trocados entre os mediadores e os responsáveis pela Ação Educativa foram gentilmente cedidos por José Aparecido Cirillo, um dos responsáveis pela Coordenação e Organização. 
mais profícua entre os mediadores e o público, ainda assim com ressalvas ${ }^{332}$. Ressalta-se que, cerca de cem pessoas foram abordadas e suas respostas inventariadas.

Tanto os empecilhos descritos pelos coordenadores capixabas em relação à metodologia que seria utilizada quanto as manifestações dos transeuntes registradas pelos mediadores são muito semelhantes às apontadas por Harriet Senie $(2004)^{333}$, no seu ensaio dedicado a analisar as reações do público com a arte ${ }^{334}$ no espaço urbano, predominantemente em Manhattan, Nova York. Já no início do texto, a autora afirmou que desconhecia qualquer mecanismo em vigor ou orçamento destinado a coletar respostas da audiência para o trabalho de arte nas ruas (2004, p.185), questão reforçada pela mesma, em escrito publicado em $2016^{335}$.

O que a maioria dos indivíduos conhece como arte pública, sublinhou Harriet Senie, deve-se ao fato destas terem sido motivo de alguma polêmica. Segundo ela, de forma geral, os meios de comunicação ignoram a arte, exceto quando a mesma é "objeto de roubo, controvérsia ou dispêndio de grande soma de dinheiro" (2004, p.196). Controvérsia foi o que desencadeou a única (salvo engano) reportagem televisiva sobre $08^{\circ}$ Salão Bienal do Mar. Poucos dias antes da data prevista para o seu encerramento, uma parte da réplica da escultura do índio, proposta pelo Coletivo Maruípe, foi destruída. O diálogo tenso e não contemplativo proposto pelo grupo - evidente, sobretudo, quando a imagem do guerreiro ficou disposta como se estivesse atacando o Palácio Anchieta (sede do governo estadual) ao invés de protegê-lo (Fig. 50) -, não despertou interesse da imprensa nem foi registrado entre os comentários do público, espontâneos ou induzidos, pelos mediadores da Ação Educativa.

332 Segundo informou Célia Ribeiro, as obras que possibilitaram uma intermediação mais efetiva foram: Atenção : Arte (Jo Name), Folhetim Sereia (Herbert Pablo Bastos), Nós vemos a cidade como a cidade nos vê (Heraldo Ferreira Borges), O Caminho das Águas (Piatan Lube Moreira), Você Vê? (Jean-Blaise Picheral) e O Retorno de Araribóia (Coletivo Maruípe). As ressalvas foram descritas no relatório dos mediadores, constando que Você vê? de Picheral ficou disposta distante das demais e, em local de menor fluxo e, dos oito deslocamentos previsto no projeto O Retorno de Araribóia, apenas três foram efetuados. Disponível em: <http://arteducelialice.blogspot.com.br/>. Acesso em: 16 set. 2017.

333 Neste texto, escrito em conjunto com Cher K. Knight é enfatizado que apesar de o público ser muito evocado, ele raramente é consultado: "a arte pública continua a ser encomendada sem muita informação sobre sua recepção" afirmam os autores, citado conclusões que observaram em 2012. Segundo eles, as circunstâncias "não mudaram substancialmente nem estão perto de serem reparadas", ressaltando ainda que entre os elementos diversos e complexos que compõem os estudos sobre a inserção da arte no espaço urbano, "o público é e continua a ser, sem dúvida, o mais evasivo" (2016, p.229). SENIE, Harriet F. Reframing Public Art: audience use, interpretation, and appreciation. In: McCLELLAN, Andrew (Ed.). Art and its Publics: Museum Studies at the Millennium. London: Blackwell Publishing, 2004. Neste mesmo livro, Katherine Gressel, no texto Participatory Public Art Evaluation: Approaches to Researching: Audience Response, registrou a histórica ausência de estudos de impacto sobre 0 assunto.

334 As obras incluíram desde esculturas heroicas tradicionais ou alegóricas até instalações de cunho contemporâneo. O método utilizado foi um questionário, acrescido de observações empíricas. 0 trabalho foi desenvolvido, em 2001, durante cerca de seis meses com estudantes de pós-graduação do The City College (CCNY), The Graduate Center (GC) of The City University of New York (CUNY) (SENIE, 2004, p.186 e nota 5, p.198).

$335 \quad$ KNIGHT, Cher Krause; SENIE Harriet F. (Edited). Introduction Audience. In: KNIGHT, Cher Krause; SENIE Harriet F. (Edited). A Companion to Public Art. John Wiley \& Sons, 2016. 


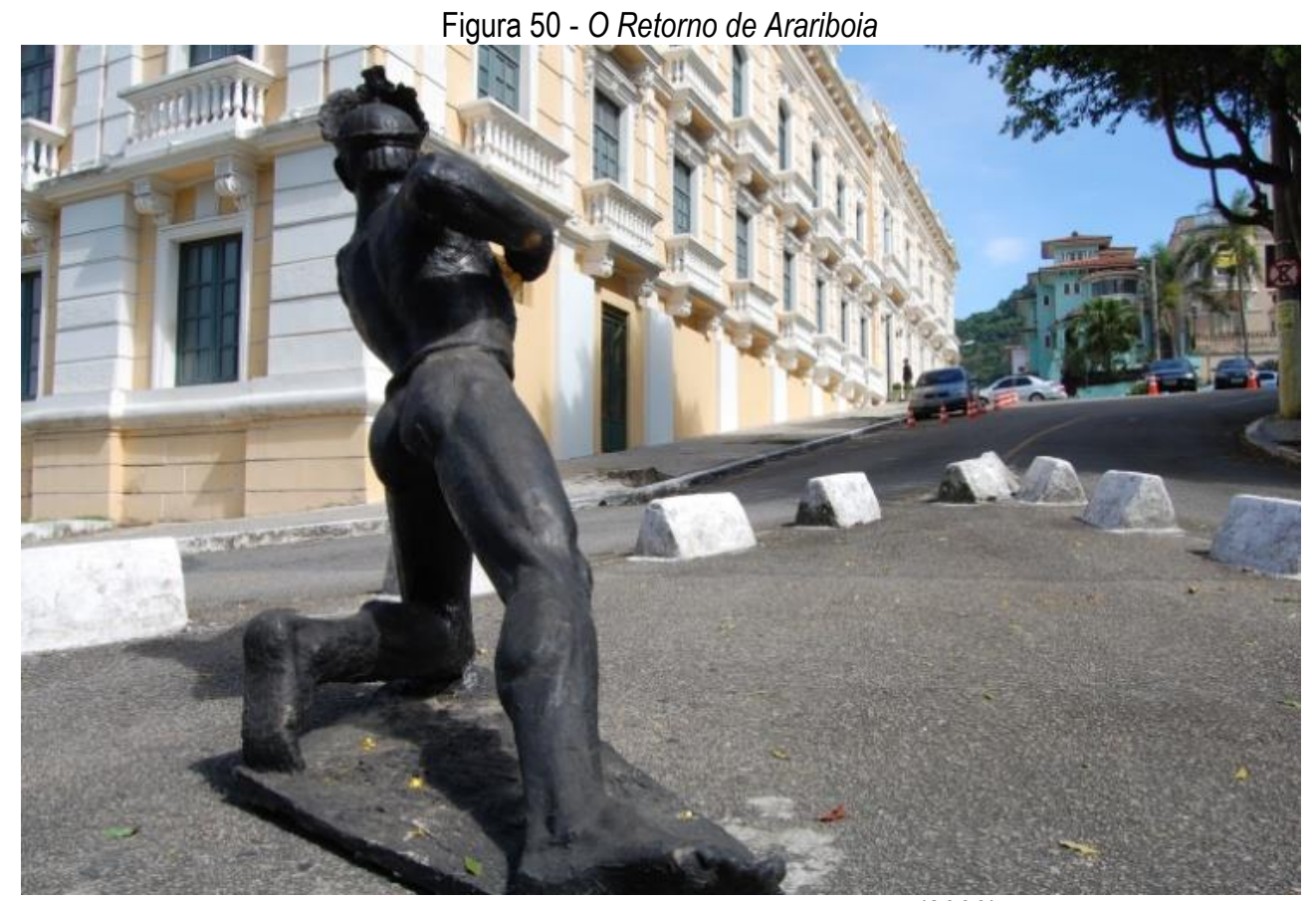

Fonte: Arquivo da autora. Foto: Raphael Araújo (2009).

Harriet Senie detectou que as pessoas, normalmente ignoram a arte nos espaços públicos ou utilizam-na de acordo com suas necessidades ou desejos (2004, p.185 e 188). Enquanto, por exemplo, moradores de rua costumam usar os espelhos d'água de alguns monumentos como banheiro, outras pessoas, independente de gostarem ou não da obra, reconhecê-la ou não como arte, adotam o trabalho como pano de fundo para fotos. Neste caso, para a autora, a função da obra é, sobretudo, servir como um marcador de tempo, para perpetuar uma lembrança (2004, p.188). Se Atenção : Arte, de Jo Name foi aquela que menos foi notada pelo público - das treze pessoas que foram interpeladas, cinco não tinham reparado nas placas ${ }^{336}$ - , tanto 0 Retorno de Arariboia quanto Nós vemos a cidade como a cidade nos vê, de Heraldo Ferreira foram muito utilizadas pelos transeuntes para fotografias.

São muitos os pontos que aproximam os resultados obtidos por Harriet Senie dos descritos pela Ação Educativa do $8^{\circ}$ Salão Bienal do Mar, entretanto, há também diferenças. A autora americana sublinhou que mediante a pergunta "Você acha que o dinheiro público deve ser usado para um trabalho como este, deveriam ter mais obras assim na cidade?" (2004, p.198), curiosamente, quase todos os entrevistados aprovaram os gastos do contribuinte com a arte (2004, p.197). Harriet Senie também afirmou que longe de perceberem as obras como "uma imposição do poder, a arte pública é adotada ou adaptada, de acordo com as atividades, audiências e inclinações" (2004, p.197). Diversamente, no caso capixaba, manifestações de indignação com a utilização de recursos públicos ocorreram, mesmo

336 Cabe destacar que, entre os abordados um era policial, ele afirmou que "nunca tinha reparado nelas e que, se não falássemos, jamais teria percebido" (Relatório realizado em 14-01-2009). 
sem a indução de qualquer pergunta, sobretudo por aqueles que não gostaram de determinadas obras $^{337}$ e a associação da inserção da arte como imposição governamental também foi exposta338.

Há outro ponto que tanto aproxima quanto diferencia as opiniões expressas pelos transeuntes de Nova York dos de Vitória: em ambos os casos foi detectado (em algumas ocasiões) certo interesse em obter informações extras sobre os trabalhos (inclusive com sugestões de confecção de materiais explicativos) ${ }^{339}$. Entretanto, ao serem estimulados a refletirem mais sobre as obras, os indivíduos de Manhattan não necessariamente alteravam seus posicionamentos iniciais, negativos ou positivos, porém, costumavam pedir desculpas por "não serem profissionais das artes" (2004, p.196). Também em Vitória, após esclarecimentos dos mediadores nem sempre as opiniões mudavam, porém, não foi localizada nos relatórios, qualquer menção semelhante à justificativa de não pertencimento ao meio artístico, citada por Senie. As opiniões mais indignadas dos transeuntes de Vitória recaíram sobre Folhetim Sereia (por ser identificada como pichação) e Atenção: Arte (por acreditarem que incitava ações de violência etc. $)^{340}$. Nestas, especialmente em relação à última, tentativas de esclarecimentos foram inócuas. Caminho das águas, por outro lado, serve para exemplificar a alteração no conceito de negativo para positivo após explanações dos mediadores.

É possível aventar que existe uma proximidade quando os transeuntes capixabas, ao contrário dos entrevistados no contexto de Manhattan, entendem que a inserção da arte no espaço urbano foi uma decisão arbitrária do prefeito e não uma proposição dos órgãos culturais ou quando manifestam indignação com gastos de recursos públicos para com a arte. Tal relação pode ser coadunada por meio da sensação enraizada de desconfiança com a existência de mecanismos democráticos efetivos no país e o diminuto poder de soberania das instituições, culturais ou não. Por fim, quando os mesmos

337 Exemplo disso, consta no relatório, parcialmente reproduzido no site de Célia Ribeiro, sobre a obra Folhetim Sereia. 0 diálogo descrito pela mediadora foi o seguinte: "Perguntou a monitora como o governo autoriza essa sujeira toda, ele identificou dois elemento da equipe como os autores deste ato de 'vandalismo'. E disse que quando ficou sabendo que era arte, ele falou para os artistas pintarem bonito, não fazer mal pintado. Ele mandou pintar barquinhos. $E$ ao saber que era obra da bienal, ficou indignado como o governo liberou esse tipo de 'coisa'" (Relatório dos mediadores de 13-01-2009). Outro exemplo: "Perguntamos (para uma senhora) o que ela achava da obra dos espelhos e ela disse: 'Isso??? É uma palhaçada! Pra que serve isso?? É gasto de dinheiro público, que poderia estar alimentando as pessoas... E um absurdo!'” (Relatório dos mediadores de 19-01-2009).

$338 \quad$ "Um taxista abordado reclamou que era coisa do prefeito, que ele faz coisas sem avisar antes e ninguém sabe de nada. Disse que era porque ele viaja muito e trouxe essa ideia inovadora para o Espírito Santo, mas não avisa o porquê do feito". Disponível em: <http://arteducelialice.blogspot.com.br/>. Acesso em: 16 set. 2017.

$339 \quad$ No caso de Vitória, exemplo disso foi um folder produzido por iniciativa e com recursos dos mediadores. 0 material trazia imagens antigas de Vitória com legendas explicativas que visavam preencher a demanda do público por referências sobre a região central antes dos aterros, como foi tratada em Caminho das águas, de Piatan Lube. Disponível em: <http://artedu-celialice.blogspot.com.br/2009/04/blog-post.html>. Acesso em: 16 set. 2017. Acesso em: 16 set. 2017 . No caso de Nova York, Senie afirmou, mencionando o desconhecimento dos usuários do metrô sobre a obra Eclipsed Time, de Maya Lin, instalada em 1994 na Penn Station (Midtown West, Manhattan) que a solicitação predominante foi por informações detalhadas e expostas nas paredes sobre a obra e a artista (SENIE, 2004, p.196).

$340 \quad$ Vale destacar que Marí(n)timo, de Melina Almada o conceito negativo, expressos por dois transeuntes, foi direcionado ao fato de considerarem a proposta inviável. 
não mencionam que o não pertencimento à área impossibilita uma análise mais aprofundada, parece claro um início do desconhecimento da existência de um campo artístico em Vitória e, por extensão do papel a ser desempenhados por esses atores, possivelmente tão invisíveis para a maioria assim como algumas obras do evento. 


\section{PARTE [2]}

\section{APROPRIAÇÕES DO EFÊMERO NO CENÁRIO CONTEMPORÂNEO: APONTAMENTOS}

Referenciado como próprio da vida contemporânea, o efêmero constitui tema recorrente na medida em que, como afirmou Zigmunt Bauman, "tudo está agora sendo permanentemente desmontado, mas sem perspectiva de alguma permanência. Tudo é temporário" (2004, p.322). Este arremate contundente acompanha a distinção entre a sociedade moderna anterior, sólida, e a atual, líquida, em que, a transitoriedade cumpriria um papel fundamental em um momento por muitos autores definido como pós-moderno, mas que Bauman denominou de modernidade líquida ${ }^{341}$. A metáfora da liquidez cumpre seu papel ao caracterizar o estado da sociedade atual, em função da sua incapacidade de manter a forma, com as alterações constantes nos quadros de referência que incluem instituições, estilos de vida, crenças e convicções, sem que haja tempo de se estabilizar "[...] em costumes, hábitos e verdades 'autoevidentes'” (2004, p.322, grifo do autor). Se no passado, a quebra era seguida pela tentativa de uma nova solidificação, agora as coisas tendem a perdurar em fluxos, voláteis, desreguladas e flexíveis.

A ênfase no temporário é inegável. Atravessando distintos segmentos artísticos, a efemeridade como característica pertencente ao contemporâneo constitui a efetividade e a singularidade de alguns (por exemplo, a música e o teatro) e outras vias e dispositivos correlacionados aos novos tempos em outras (como é o caso da própria performance no contexto das artes visuais). Nas artes cênicas, por exemplo, a principal característica que a distingue das outras artes, segundo sua tradição teórica, é o evento que efetiva o encontro com o público, tão fugaz e único em sua natureza que todos os seus elementos constituintes ensaiam exatamente o ponto efêmero que a fundamenta. Ainda que haja uma preparação prévia em todos os segmentos da engrenagem teatral, é na arte deste encontro que 0 teatro acontece ou não. A captura ou registro deste instante de concretização é impossível, o que delegou à edição dos textos teatrais, o prospecto de arquivamento de sua suposta memória perante a impermanência de sua fenomenologia.

\footnotetext{
$341 \quad$ Nesta entrevista, concedida à Maria Lúcia Garcia Pallares-Burke, Bauman expõem de forma concisa — apesar de clareza e concisão serem características intrínsecas aos seus textos a partir da década de 1990, conforme foi observado diversas vezes, tanto pelo próprio autor quanto por seus comentadores - o porquê da adoção do termo líquido que intitula vários de seus livros. Segundo ele: "Uma das razões pelas quais passei a falar em 'modernidade líquida' e não em 'pósmodernidade' (meus trabalhos mais recentes evitam esse termo) é que fiquei cansado de tentar esclarecer uma confusão semântica que não distingue sociologia pós-moderna de sociologia da pós-modernidade, 'pós-modernismo' de 'pósmodernidade'. No meu vocabulário, 'pós-modernidade' significa uma sociedade (ou, se se prefere, um tipo de condição humana), enquanto 'pós-modernismo' refere-se a uma visão de mundo que pode surgir, mas não necessariamente, da condição pós-moderna" (PALLARES-BURKE, 2004, p.321). Embora, a utilização exacerbada do termo cunhado por Bauman, especialmente no meio acadêmico, tenha desgastado seu impacto inicial, a profusão da sua utilização não deixa de ser um barômetro para aferir sobre o alcance da capacidade de síntese do autor sobre questão tão complexa.
} 
[...] para o teatro, a questão é sempre o tempo vivido, a vivência temporal que atores e espectadores partilham e que evidentemente não é mensurável com exatidão, mas apenas experimentável. A análise e a reflexão acerca do tempo teatral dizem respeito a essa experiência (LEHMANN, 2007, p.287) ${ }^{342}$.

Ainda assim, na segunda metade do século XX, principalmente nos últimos decênios, observa-se uma frente crescente no pensamento teatral que procura reafirmar o caráter efêmero, eliminando indícios de uma teatralidade tradicional diante de uma noção de acontecimento. 0 caráter fugaz foi incorporado ao plano conceitual e metodológico da topografia artística em proporções que chegam a ser tomadas quase como uma premissa da contemporaneidade, tensionando as linhas de força que 0 campo e suas questões mobilizam ${ }^{343}$. Entre 0 encanto com as novas potencialidades do admirável novo mundo (conforme Aldous Huxley intitulou seu livro) e sua rejeição — com a consequente volta à tradição, idealização do passado ou de contexto cultural exótico no qual a velocidade dos novos tempos ainda não destruiu o tempo "normal" do homem -, a arte contemporânea parece ter optado por adotar um posicionamento parcial, enclausurando o "efêmero" dentro de um pacote conceitual com múltiplos outros adjetivos anexados. A prática artística, semelhante ao discurso teórico que muitas vezes procura espelhar, selecionou um determinado tipo de efêmero, apropriado e recorrente em ambiente específico, em que uma feição plácida pode não corroborar com a dinâmica ansiosa vivida nas grandes cidades das últimas décadas. Transformado em objeto, o "não permanente" passa a ter importante papel utilitário dentro dos eventos de arte, tanto para artistas quanto para produtores vinculados a instituições. Para os artistas, fornece apoio metodológico no tratamento dos mais variados temas: relações humanas, existencialismo, corporeidade, são exemplos recorrentes na história da arte que ganham caráter contemporâneo ao ser associado ao "efêmero" como ferramenta. De modo semelhante, a produção de eventos não permanentes, ao agregar o caráter de variedade, velocidade e consumo, resolve problemas operacionais trazidos pela permanência - manutenção das obras e da audiência, além da ocupação de espaço público. Entre poesia e produção, a não persistência das obras promove exemplos concretos sobre o direito à apropriação do espaço público, carregando outro conceito muito debatido na contemporaneidade: a democracia.

Nesse sentido, a constituição artística de um estereótipo para o "efêmero" e seus correlatos virtual, imaterial, oral, velocidade, ineditismo, variação, atualização, mutabilidade, deslocamento, performático — antes de ser problematizada pela cadeia artística, é assimilada por ela ${ }^{344}$. Tomados

\footnotetext{
342 LEHMANN, Hans-Thies. Teatro pós-dramático. Tradução de Pedro Süssekind. São Paulo: Cosac \& Naif, 2007.

343 As considerações em relação ao teatro são tributárias do auxílio competente de Éder Rodrigues da Silva. Além das indicações bibliográficas ele também revisou o texto.

$344 \quad$ É evidente que exceções não faltam. Alusivo disso é a resposta de Nuno Ramos a Vanda Klabin. "VK - As suas esculturas de areia queimada, fundida e socada, de aparência frágil e instável, parecem guardar uma imediaticidade da experiência, reter o singular. Os elementos de dissolução parecem ser uma constituinte do seu processo de trabalho. Mas permanece um aspecto ambíguo, presidido por dois movimentos: saber se impregnar / saber se desmanchar. Você busca
} 
como sinônimos, portanto, ou, implícitos no conceito principal, efêmero et al é visto como um pacote, um todo constituído, arranjo metodológico pronto para utilização pelo artista e compreensão confortável pelo espectador. A abundância verificada em obras e eventos efêmeros nas últimas décadas não é, entretanto, refletida no debate teórico do tema que, de forma geral atualiza algumas coordenadas estabelecidas nas décadas de 1960 e $1970{ }^{345}$. Neste sentido, dois textos de Patricia Phillips - Temporality and Public Art (PHILLIPS, 1989) 346 e The Time Frame: Encounters with Ephemeral Public Art (PHILLIPS, 2016)347 - serão adotados como exemplos da posição da centralidade do conceito de efêmero no campo artístico nas últimas décadas.

Pressupondo tempo, lugar e intensidade, associando-o ao final do século $X X$, período em que objetos permanentes são vistos com desconfiança, o "efêmero" é identificado como característico da paisagem pública pela autora:

A realidade do efêmero talvez seja mais persuasivamente e inequivocamente sentida na vasta paisagem pública. $O$ privado pode oferecer algum refúgio tranquilo, alguma constância de rotina, mas a vida pública tornou-se emblemática não daquilo que é partilhado pelos cidadãos, mas das diferenças mutáveis e inquietas que a enriquecem. A vida pública é inicialmente previsível e constantemente surpreendente (PHILLIPS, 1989, p.331).

A ênfase dada por Patricia Phillips à paisagem pública em detrimento do cenário privado é digna de nota não apenas por traduzir textualmente uma prática já disseminada no campo artístico, mas também por revelar a condução discursiva em direção à criação e legitimação de um espaço possível para a produção artística alternativo aos preexistentes. Uma narrativa é forjada para estabelecer a primazia do vínculo entre o "efêmero" e a arte no espaço urbano, em que "rotina" e "tranquilidade" são termos colocados em oposição à ideia de "temporário" implicando em equívocos que, embora sutis, correndo o risco de serem entendidos como diminutos, são suficientes para esvaziar a relação "efêmero" e ambiente público.

uma permanência, uma fixação do efêmero ou quer apagar a experiência da ação? NR - Não faço nenhuma apologia do efêmero - aliás, detesto essa história de arte efêmera desde que a Mira Schendel me falava disso, há quase 20 anos. Trabalho muitas vezes com a matéria numa situação limite, que exige grandes cuidados e precauções. Mas nunca quis que meus trabalhos se desfizessem. Tenho, como tantos outros artistas, desenhos e indicações de montagem para cada um de meus trabalhos, que podem sempre ser refeitos. Procuro levar o trabalho ao instante imediatamente antes de uma grande transformação ou catástrofe - não tenho nenhum interesse na catástrofe mesma." Nuno Ramos x Vanda Klabin: Diálogo de aferição. Disponível em: <http://www.canalcontemporaneo.art.br/blog/archives/2006_04.html>. Acesso em: 29 abr. 2017.

345 Como por exemplo, o livro clássico de Lucy Lippard Six Year: the desmaterialization of the art object - 1966-1972.

346 PHILLIPS, Patricia C. Temporality and public art. Art Journal, JSTOR, v. 48, n. 4, p.331, 1989. Disponível em: $<$ http://dx.doi.org/10.2307/777018>. Acesso em: 29 abr. 2017.

347 A segunda publicação da autora, The Time Frame: Encounters with Ephemeral Public Ar, seria uma espécie de retomada do tema, mais de 20 anos depois. Sua abordagem, entretanto, é menos analítica que a anterior e poderia ser considerada uma série de descrições de trabalhos que lidam com o efêmero onde o enfrentamento do conceito é evitado. 


\subsection{Rotina e exceção temporárias}

Na tentativa de localização do habitat natural para o "efêmero", a ideia de "rotina" produz dois equívocos. O primeiro consiste na sua associação ao ambiente privado, como esperança de diferenciação entre espaços, na medida em que a dinâmica aparentemente caótica do público pode também ser esquematizada, organizada, referenciada por símbolos, em que o acaso não mais surpreende. Acidentes, incidentes, discussões, tumultos, estranhamentos, compõem o espectro do esperado e apropriado ao universo público e, dependendo do grau de internacionalização do espaço em questão, elementos ainda mais bizarros podem compor a rotina pública. Se é fácil inferir que a globalização, alcançada pela integração in loco, digital, ou pelos bens de consumo, tornou os mistérios do mundo ainda mais raros, isso não quer dizer, entretanto, que o homem contemporâneo seja menos ingênuo e sim que possui mais informação. É nesse cenário, no qual a indústria cultural, por meio de propagandas, filmes, músicas, vlogs, blogs e eventos artísticos, tem suprido o indivíduo de conteúdo, nos espaços tanto públicos quanto privados, a noção de extraordinariedade é incorporada ao cotidiano.

Não é o "efêmero", portanto, nem a "rotina" que estabelecem a diferença entre o espaço público e o privado, diferentemente do que bradou Phillips. Dentre as peculiaridades delineadoras de um perfil, a quantidade de estímulos ou a competição pela atenção do transeunte consiste em característica ordinária, rotineira e permanente do espaço público ${ }^{348}$. Como competidor no cenário citadino, a inserção da arte no espaço urbano enfrenta a questão da visibilidade diante dos apelos ordinários de múltiplas maneiras. Analisando o conjunto de obras do $8^{\circ}$ Salão Bienal do Mar, é possível distinguir diferentes estratégias de apropriação da atenção no espaço público. De modo incisivo, a utilização de recursos típicos do marketing publicitário é a mais acessada. Esse é o caso da utilização dos vidros que compõem os pontos de ônibus como suporte por Herbert Pablo em Folhetim Sereia para sua apresentação. Espaço de parada obrigatória, as guaridas de espera pelo transporte público coletivo são ambientes disputados para divulgação de eventos, promoção de ofertas de consumo, difusão de ideias anárquicas por pichação ou rabiscos, e obras artísticas. Camuflado como serviço, Melina Almada, em Marí(n)timo, instalou bibliotecas nos pontos de ônibus com livros que versavam sobre 0 mar. Com instruções ${ }^{349}$ que estimulavam o uso dos volumes pelos usuários de transporte

\footnotetext{
$348 \quad 0$ ambiente privado também é permeado de ataques sensoriais, mas estes acontecem, em sua maioria, por vias de conexão com o espaço público, como telefone e correio, ou por espaços públicos acessados no ambiente privado como internet e televisor.

$349 \quad$ No projeto apresentado, a artista elaborou um "Manual do usuário da biblioteca Marí(n)timo" composto por seis tópicos, são eles: 1) Todos os livros pertencentes ao programa de bibliotecas Marí(n)timo são de uso coletivo, então lembrese é de todos e de ninguém; 2) Todos poderão retirar, sem cadastro prévio, os livros das estantes e devolver dentro do prazo de uma semana em qualquer outro ponto; 3) Lembre-se da data da devolução, ela não será cobrada, é de sua inteira responsabilidade a devolução do título em qualquer um dos 10 pontos; 4) É recomendado não rabiscar, escrever, colar,
} 
coletivo, a estratégia aqui é a mesma adotada em serviços públicos como os de bicicletas, estacionamento ou telefonia.

Por outro lado, Lucimar Bello, em Líquidas Fronteiras, firmou a visibilidade de seu vídeo por meio de projeção na fachada de um prédio, tal como os outdoors estáticos ou digitais. Denominado de vasas.cidades.dos Alpes ao Ilha de Capri, o vídeo exibido faz parte de uma trilogia ${ }^{350}$ que discute "cidade e subjetividade em perspectivas micropolíticas" (BELLO, 2008). Por mais de dois anos ${ }^{351}$, enquanto residia no Edifício Alpes - no bairro de Perdizes, em São Paulo - , a artista fotografou (Fig. 51) das janelas do seu apartamento, a construção do prédio llha de Capri. O imóvel que ela morava foi construído na década de 1950 e possuía quarenta apartamentos em seus vinte andares, o outro, com apenas dezesseis pavimentos continha duzentas e cinquenta e seis unidades. A dinâmica voraz do mercado imobiliário, "engolindo casas, jardins, quintais e história" (BELLO, 2008), questão presente no projeto, possivelmente, não tenha alcançado o impacto pretendido de "ativar sensações de 'des[co]lamentos construcionais' nas pessoas como se estivessem num 'campo de obras em construção" (BELLO, 2008). As imagens dos três vídeos - com duração de 4,47' (cada) - projetados em sequência sobre uma das empenas do Edifício Fabio Rushi352, foram ofuscadas pela iluminação

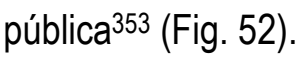

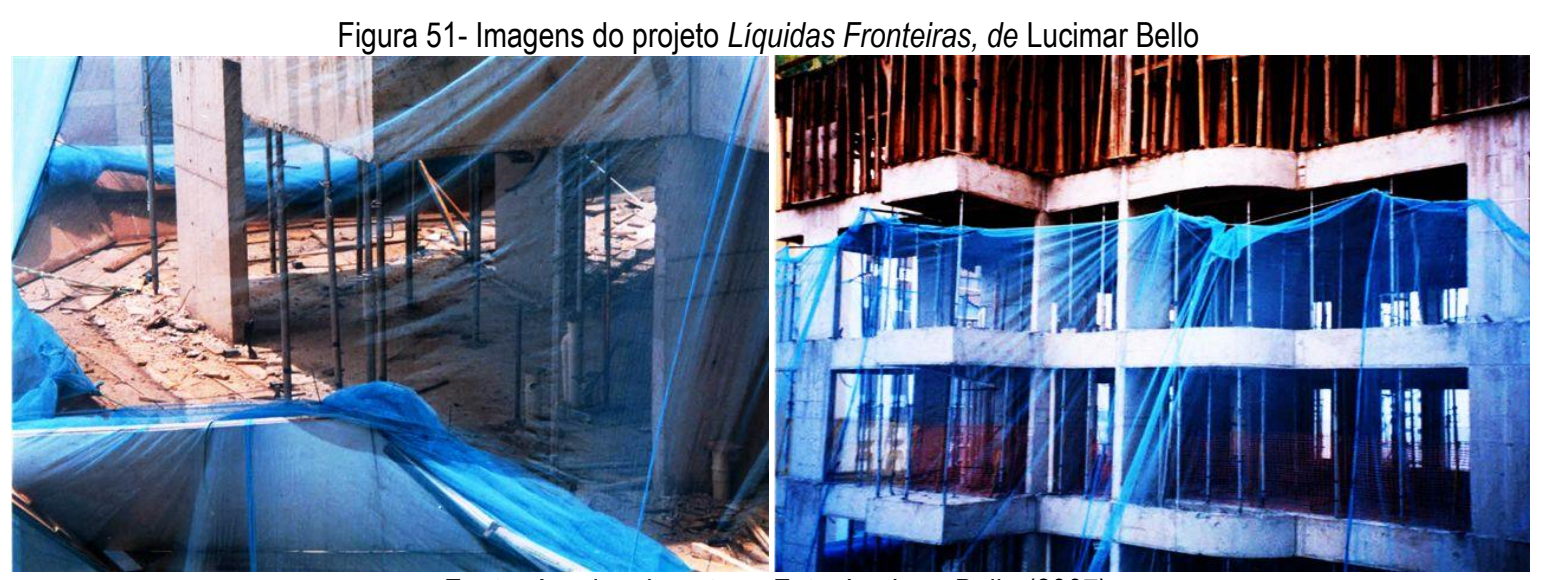

Fonte: Arquivo da autora. Foto: Lucimar Bello (2007).

rasgar ou arrancar as folhas dos livros; 5) Caso você deseje doar um livro, sinta-se a vontade. Escreva na primeira página um termo de doação, traga e coloque na estante; 6) Entre no site http://www.marintimomar.blogspot.com/ e confira os títulos existentes e as atualizações.

350 Os outros dois vídeos foram intitulados de Cartemas e Verbetes, conforme consta no projeto apresentado ao $8^{\circ}$ Salão Bienal do Mar.

351 Segundo consta no projeto encaminhado, o Edifício llha de Capri foi construindo entre os anos de 2002 até 2004.

352 As exibições foram realizadas entre os dias 20 a 24 de dezembro de 2008 , das 20 às 22 horas. A estrutura de projeção foi instalada na lateral do Edifício BEMGE.

353 Questão semelhante pode ser aferida visualizando o vídeo que o Coletivo El Perro realizou das projeções sobre edifícios públicos espanhóis, em Virtual Demolition Mobile. No caso, espanhol, como a iluminação pública e das fachadas são mais intensas do que em Vitória, a projeção foi ainda menos impactante. Cf. <http://www.democracia.com.es/proyectos/virtualdemolition-mobile/>. Acesso em: 14 abr. 2017. 


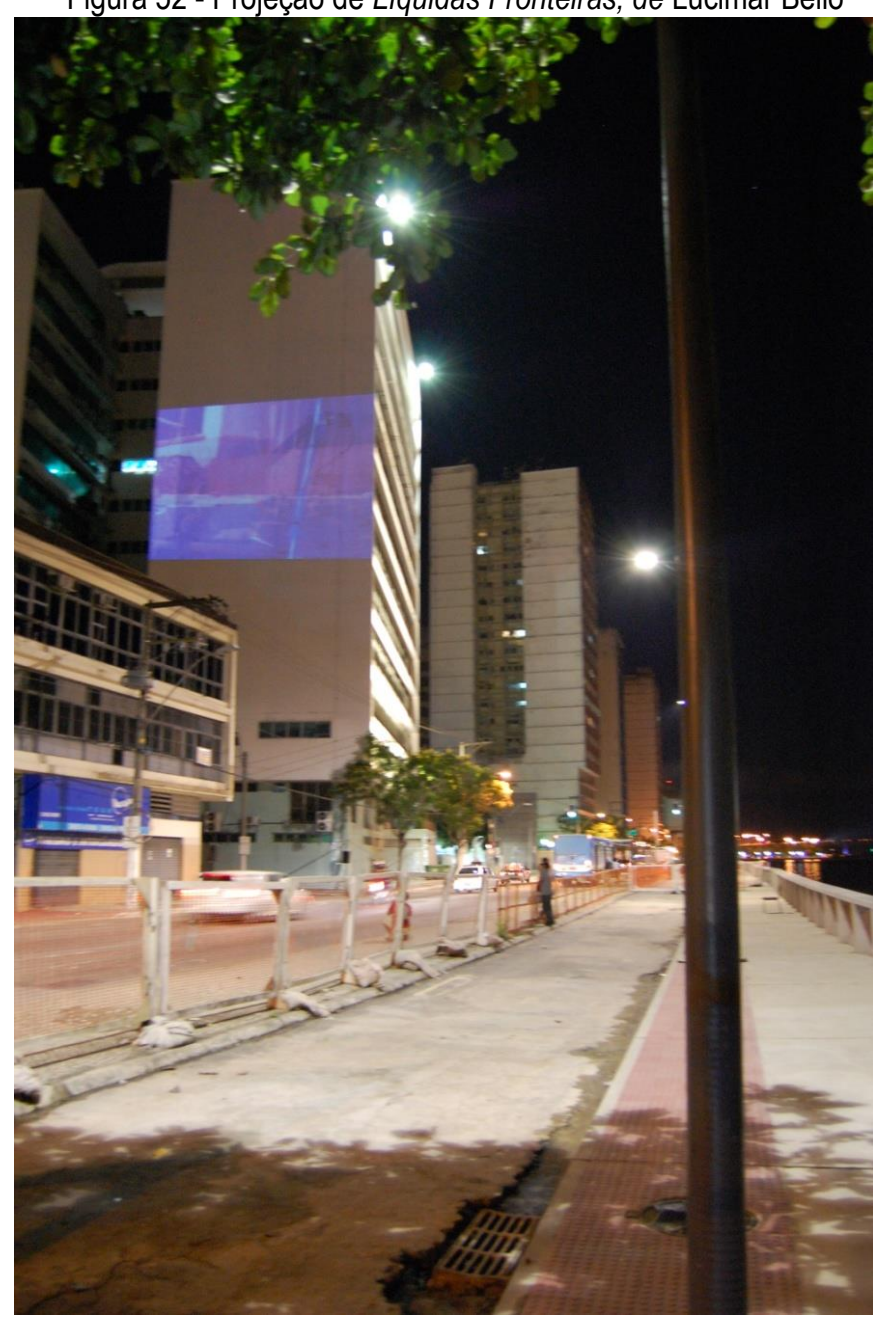

Fonte: Arquivo da autora. Foto: Raphael Araújo (2008).

Sob outra perspectiva, adotando uma estratégia amplamente usada pela administração pública, Jo Name em Atenção: Arte recorreu ao design sisudo das placas de sinalização para prestar informações inusitadas. Porém, as duas placas (Fig. 53) dispostas nas extremidades do percurso (na entrada da llha da Fumaça e nas proximidades do armazém 5 do Porto de Vitória), em uma espécie de apresentação do trabalho, traziam o título do projeto e o perfil de um rosto, acima do qual, os pontos de exclamação e interrogação visavam demonstrar surpresa e questionamento da informação ${ }^{354}$. Assim, ao sublinhar de forma didática suas intenções para com o espectador, a pretensão de "provocar estranhamento a até repulsa" são dissipadas. 
Figura 53 - Imagem do projeto ATENÇÃO: ARTE, de Jo Name

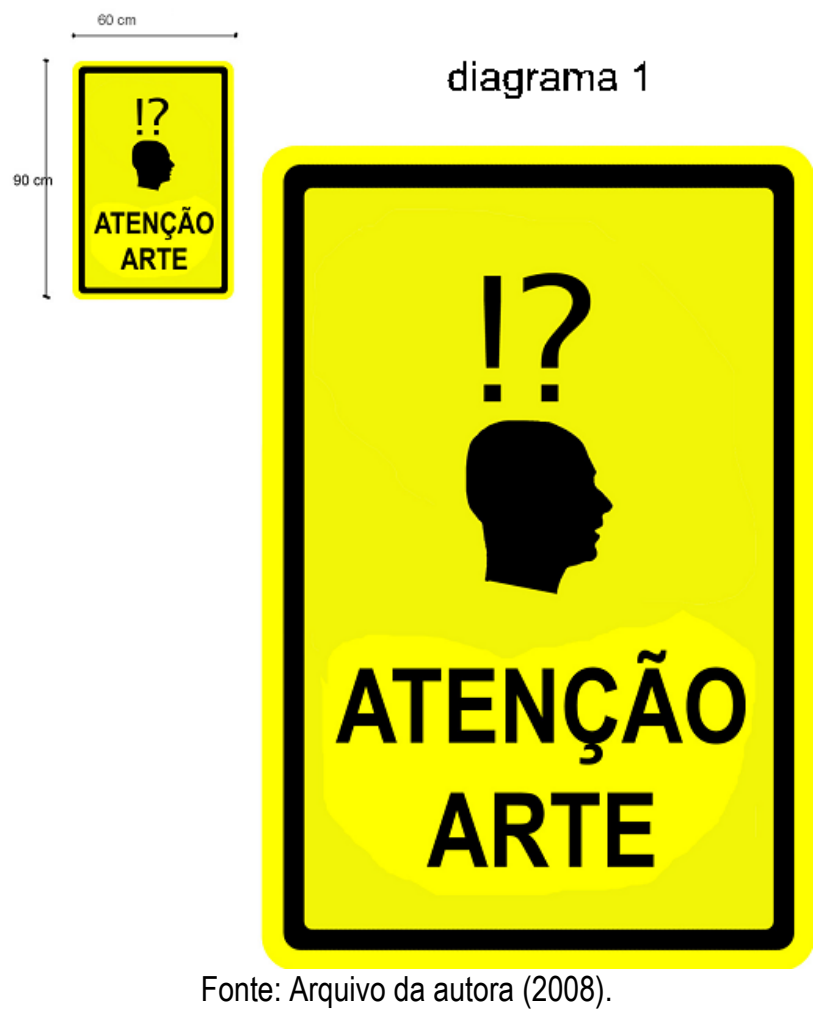

No murmurinho público, nem sempre quem fala mais alto recebe mais atenção, ainda assim, 0 apelo ao auditivo foi proposto [apesar de não concretizado] na intervenção grandePEQUENAcatraia de Marcelo Gandini, na qual, uma diminuta catraia emularia a sinalização sonora de uma embarcação avantajada com o objetivo de causar surpresa ao transeunte ${ }^{355}$. Diversos ruídos compõem o campo do esperado em uma cidade grande, originados do trânsito, dos alto-falantes das lojas, e, nas cidades com zona portuária, as buzinas de navios. Deste modo, a sonoridade da grande embarcação é sinal presente no cotidiano do morador de Vitória, surpreendendo mais o turista do que seus habitantes.

Se 0 transeunte contemporâneo desenvolveu defesas ao assédio visual e auditivo nos centros maiores, talvez interpelá-lo diretamente garanta a visibilidade necessária. Em Ego trip pré-sal (Fig. 54), João Wesley e Sandro Souza dispuseram uma plataforma elíptica flutuante com aproximadamente $7 \times 4$ metros na entrada da Baía de Vitória. Sobre essa foi impressa a imagem de mãos segurando aberto 0 jaleco laranja dos plataformistas da Petrobrás para exibir uma barriga estufada para o céu enfatizando, conforme escreveram os artistas, um "[...] ponto de inflexão provocado pela inclusão do Espírito Santo na produção petrolífera do pré-sal e, como este fato poderia, em tese, transformar o imaginário local" (In: RUFINONI; MARGOTTO, 2009b, p.91), construindo uma imagem aglutinadora de sua identidade.

\footnotetext{
$355 \quad O$ apelo ao auditivo, destinado a surpreender o transeunte, foi repensado pelo artista. Ele registrou e disponibilizou um vídeo da travessia, no qual, dialoga com os tripulantes da catraia. Disponível em: <https://www.youtube.com/watch?v=kyzTxgTbwhE>. Acesso em: 04 dez. 2018.
} 
Sobre a imagem, constava a sentença: O meu umbigo é o centro do mundo. Além disso, os artistas, mimetizando o uniforme da empresa, distribuíram buttons aos passantes com o título da intervenção (Fig. 55).

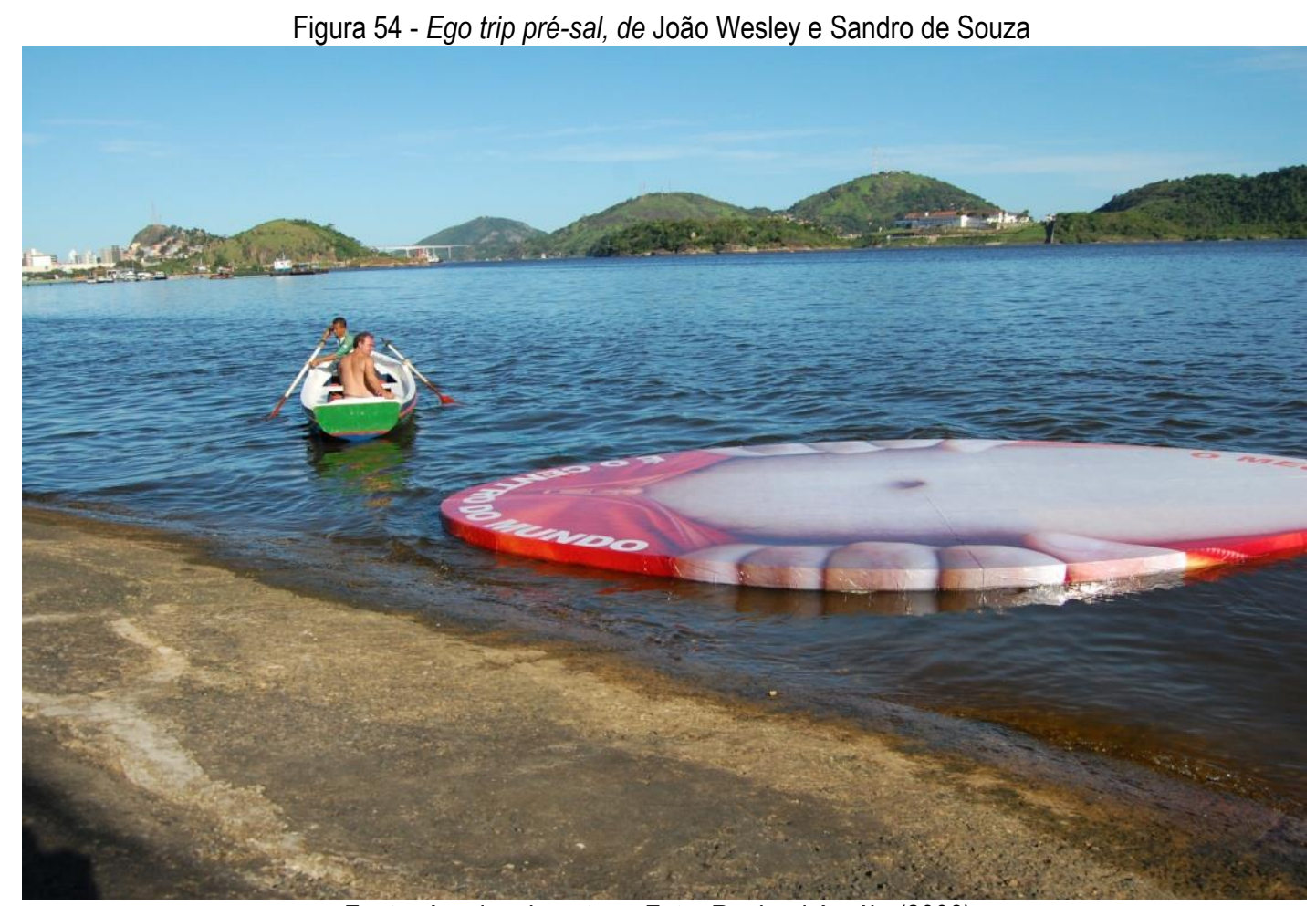

Fonte: Arquivo da autora. Foto: Raphael Araújo (2008).

Figura 55 - João Wesley e Sandro de Souza entregando buttons aos transeuntes

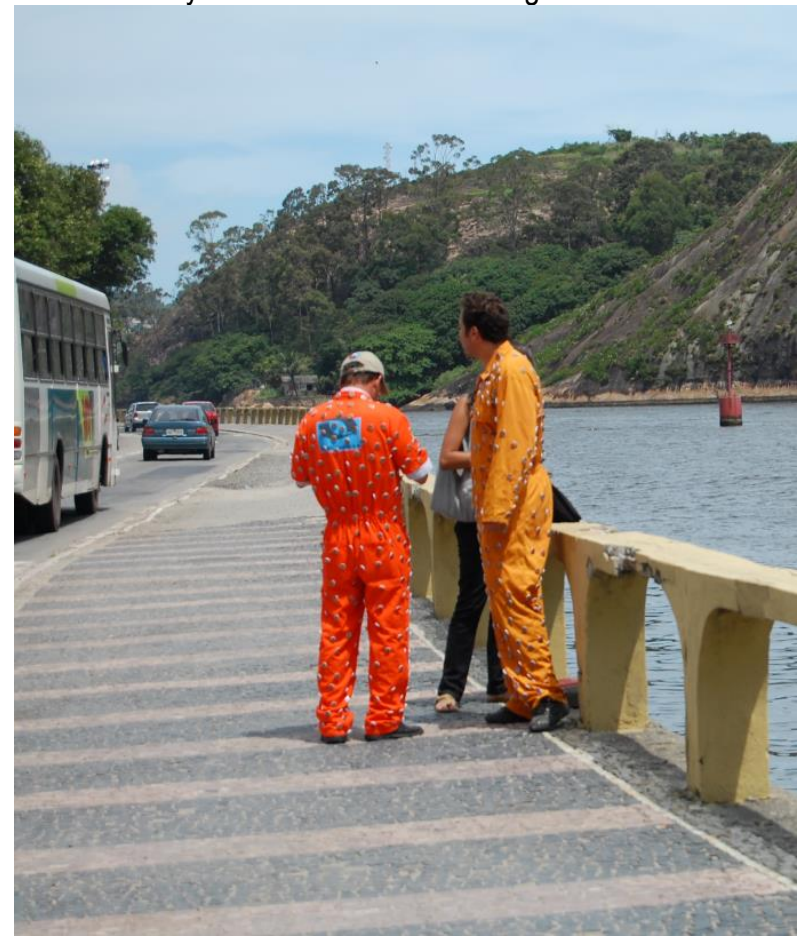

Fonte: Arquivo da autora. Foto: Raphael Araújo (2008). 
Figura 56 - button de Ego Trip Pré-sal

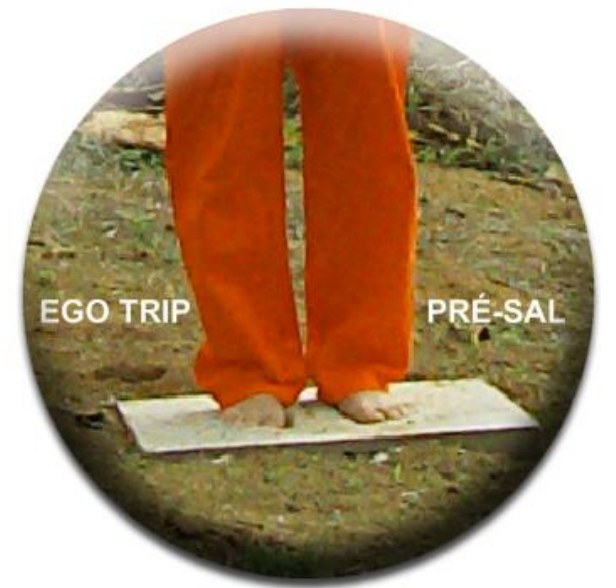

Fonte: Arquivo da autora (2008).

Se, por um lado, a opção por métodos incisivos como os descritos acima, revelam a tentativa de se fazer notar na imensidão de estímulos urbanos e derreter as defesas do transeunte, por outro, alguns artistas, adotaram uma postura distinta. Laerte Ramos em Do pó ao pó, contratou um performer para perambular por ateliês, museus e galerias da cidade aspirando seu pó (Fig. 56). 0 material coletado, o registro em vídeo da ação e os equipamentos utilizados foram dispostos na sede do evento, acompanhados por um texto do artista colado na parede (Fig. 57).

Figura 57 - Do pó ao pó, de Laerte Ramos

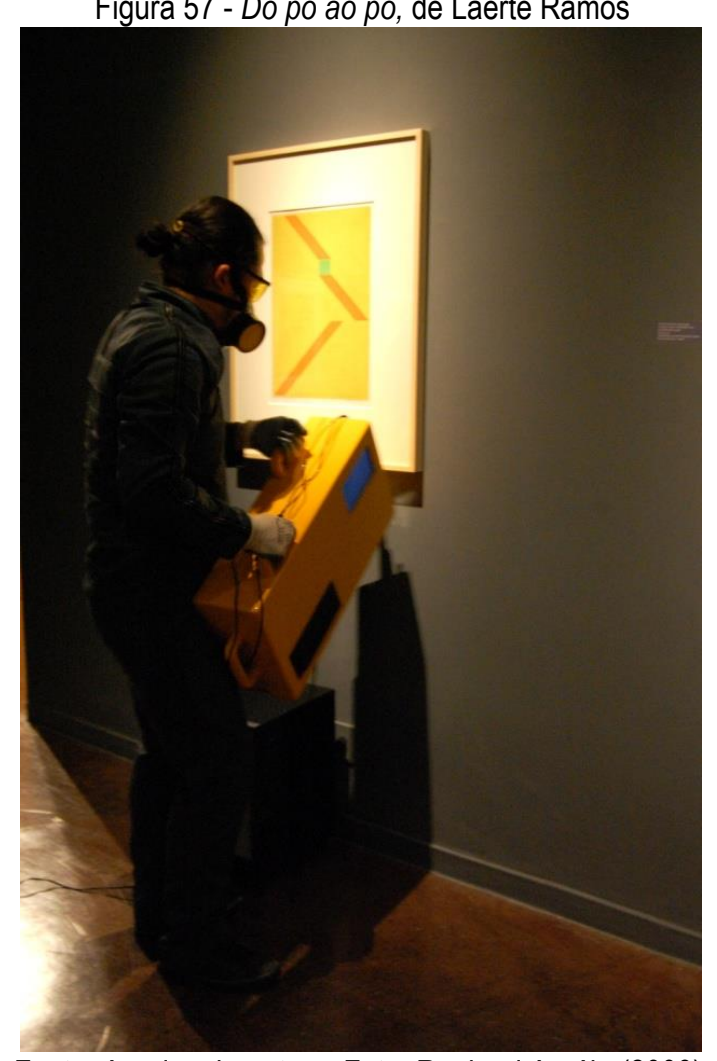

Fonte: Arquivo da autora. Foto: Raphael Araújo (2009). 
Figura 58 - Exibição do vídeo Plus Ultra, de Oriana Duarte

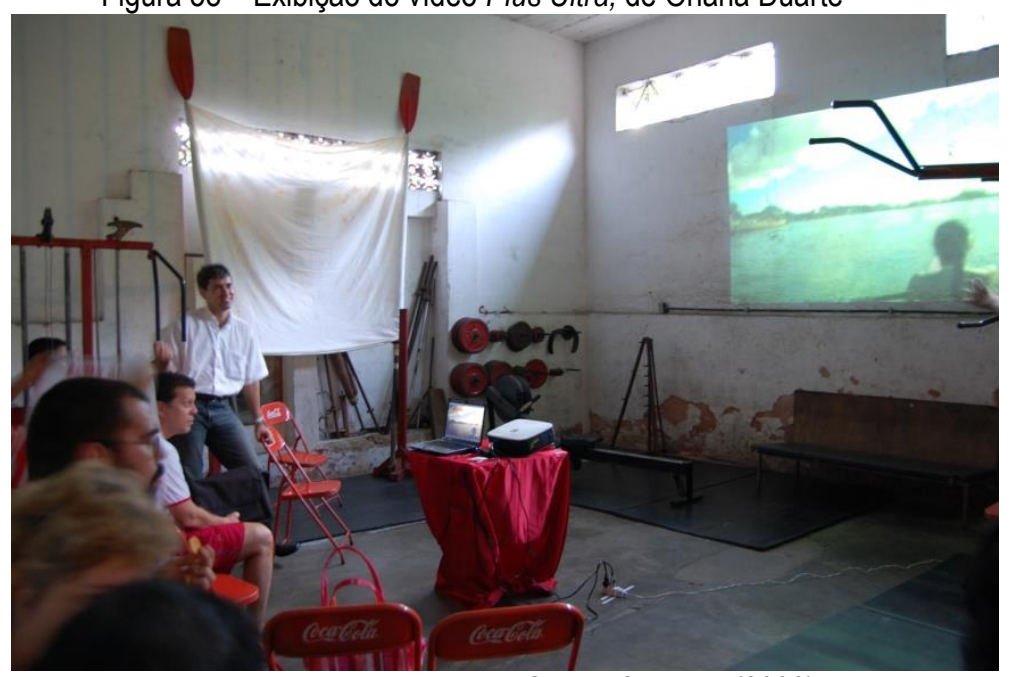

Fonte: Arquivo da autora. Foto: Gibran Chequer (2008).

De forma semelhante, a performance de Oriana Duarte, Plus Ultra - sessões a remo pela baía de Vitória -, foi condensada em registros de vídeos editados e exibidos no Clube de Regatas Saldanha da Gama de Vitória (Fig. 58) e, posteriormente disponibilizados na sede do $8^{\circ}$ Salão Bienal do Mar. 0 retorno ao indoor nestes casos revela não apenas uma independência em relação ao espectador como material na constituição das obras — de modo diferente ao pretendido nos trabalhos de Melina Almada, Heraldo Ferreira, Herbert Pablo, Marcelo Gandini e Fabrício Carvalho que, de forma mais ou menos proeminente, visaram tratar o fruidor como participante - , mas também do espaço urbano como nova plataforma expositiva, como o fizeram o restante dos trabalhos, juntando-o como material poético e recorrendo ao espaço privado para sua apresentação.

Finalmente, dois trabalhos não recorreram a qualquer artifício explícito de visibilidade. 0 primeiro deles, silencioso em menor grau que o segundo, foi realizado por Fabrício Carvalho. Em 0 Silêncio do Martelo, o artista reorganiza objetos abandonados nas ruas em forma de instalação. Neste, não há qualquer indicação marcante ao transeunte a não ser a forma plástica escultórica dos objetos. Tal arranjo, não teve longa duração, uma vez que, não sinalizado como obra, suas peças sumiram, possivelmente, conforme já exposto, levadas pela coleta regular de lixo. Por último, Caminho das Águas de Piatan Lube que consistiu em uma faixa azul pintada na calçada emulando 0 antigo traçado aterrado do mar. A simples linha, no chão, não poderia ser mais sutil ao transeunte apressado. Entretanto, embora esteja ao relento, sujeita às intempéries do tempo e à ação dos usuários das ruas, a marca de Piatan Lube é a única obra efêmera daquele evento que ainda hoje pode ser vista nas ruas de Vitória - o fato dela ter sido reforçada em duas ocasiões, incrementando sua vida útil, não suplanta o espanto por sua persistência. É neste aspecto que as estratégias de visibilidade, de se fazer notar, chamar atenção para sua existência, determinam o grau de efemeridade das obras no espaço público. 
As obras notáveis, visíveis - mesmo que sem a aura artística como foi o caso de O Silêncio do Martelo - constituíram em incômodo ao usuário ou ao poder público e tiveram seu tempo de existência demarcado, enquanto que a obra mais discreta, invisível, não inconveniente no sentido prático aos cidadãos ou à administração pública, permaneceu. Na rotina do espaço público, portanto, se destacar torna o trabalho visível enquanto objeto, mas não como obra. A consequência seguinte é a invisibilidade, pois, como objeto, iguala-se aos demais no cenário.

Esta visita às estratégias metodológicas de visibilidade dos projetos do $8^{\circ}$ Salão Bienal do Mar, não constituem crítica às obras, mas evidências do equívoco recorrente na ligação, já clássica, como vistos em Phillips, entre o "permanente" e ambientes de "rotina", ou, de modo contrário, o "efêmero" e ambientes de "raridade". Assim, a adoção de medidas ativas - agressivas e apelatórias, típicas dos ambientes públicos urbanos - como tentativa de adquirir visibilidade, resulta, entretanto, em camuflarse na rotina poluída do espaço público já repletas destes tipos de estímulos. Como resultado, os objetos partilham, ao mesmo tempo, de uma visibilidade e invisibilidade. São visíveis porque incomodam enquanto obstáculos, chamados ou sinais, e invisíveis porque, uma vez identificados como mais um dentre os vários solicitantes, são deliberadamente ignorados pelos dispositivos de defesa do transeunte. Com isso, é possível inverter a dependência proposta por Patricia Phillips: no espaço público, a rotina extraordinária pode potencializar o efêmero, uma vez que os trabalhos, visíveis enquanto objetos e invisíveis como obras de arte tanto pelo transeunte quanto pela operacionalização pública, precisam desocupar o espaço urbano. Por outro lado, evitando aderir aos mecanismos apelatórios típicos do ambiente, a discrição empreendida por Caminho das Águas, em processo atípico, extraordinário na flora pública, torna-se permanente.

\subsection{Material e imaterial temporário}

O segundo equívoco com o uso do termo "rotina", proposto por Patricia Phillips, deriva da pressuposição implícita de que o "efêmero" não é possível nos ambientes rotinizados, uma vez que a repetição do evento seria suficiente para determinar sua permanência. Tal "a priori", obviamente inconsistente, torna distinguível a existência de pelo menos duas classes do "efêmero": uma relativa à exígua duração do fenômeno e, outra, à sua impossibilidade de repetição. É possível, portanto, chamar de "efêmera" uma ação ou objeto de curta duração, ainda que seu tempo seja indeterminado, ao mesmo tempo em que uma ação ou fenômeno único, não replicável, poderia igualmente ser denominado de "efêmero". Esta classificação rejeita a inclusão da natureza do material constituinte da obra como fator determinante na distinção dos tipos de temporariedade. A irrecusável separação entre 
arte efêmera material e arte efêmera imaterial, quanto à espécie dos componentes da obra são determinantes, pode ser identificada em texto mais recente de Patricia Phillips:

\begin{abstract}
Neste contexto, é importante identificar - e sublinhar - diferentes trajetórias da temporalidade. Existem obras de arte pública temporária que facilmente poderiam tornar-se permanentes ou duradouras por meio de oportunidades receptivas ou espaços que suportam longevidade ou permanência. Por exemplo, muitas instalações escultóricas, incluindo as principais obras de Alice Aycock, Wim Delvoye, Christian Jankowski, Sarah Sze, Franz West e outros (que o Public Art Fund patrocina no Doris C. Freedman Plaza na entrada sul de Central Park de Nova York), poderiam ser instaladas permanentemente em outros ambientes. Esses trabalhos são evocativos ou previsivelmente adequados a condições ambientais ou contextuais específicas, e não têm uma vulnerabilidade material particular ou precariedade deliberada. Teoricamente, esses trabalhos poderiam ser permanentemente situados em um local definitivo ou uma coleção de arte ao ar livre, como Storm King Art Center, em Mountainville, Nova York.

Se este tipo de arte pública temporária contribui incontestavelmente para a vitalidade de um espaço ou cidade, o centro de gravidade deste capítulo repousa sobre a obra que, intrinsecamente ou cronicamente, envolve ou evolui dentro de um espaço por meio de características que geralmente não possuem uma presença material persistente, como luz, fala e som, mas muitas vezes usa materiais vulneráveis, atividade somática, ou comportamento ou movimento. É para esta obra que a efemeridade e a iminência, a contingência e a urgência oferecem ocasiões de significado que podem produzir uma vida após a morte ressonante - se incalculável — para além da duração e da existência da obra real (PHILLIPS, 2016, p.360).
\end{abstract}

Infelizmente, a autora não aprofundou a discussão, aparentemente incômoda, mas o excerto coletado é útil como exemplo da classificação de obras efêmeras por qualidade, ou, de modo mais específico, tangibilidade de seu material, no qual uma hierarquia é produzida: quanto mais intangível for, mais força seria promovida pelo efêmero na ressonância da obra no espectador. Uma nova premência, portanto, é identificada na potencialização do "efêmero" pelo "intangível", em que obras duráveis seriam mais triviais. Reflexo de um processo crescente desde Marcel Duchamp, a desvinculação com as tradições artesanais e sua relação direta com o material atingem seu cume na supervalorização do artista projetista, analítico, pensador, numa tentativa de elevação do seu status na cadeia disciplinar na qual a ideia, constituída de elementos abstratos, é a própria obra. Utopia, entretanto, é imaginar uma lógica diferente daquela que pretendia abandonar com a mera troca da qualidade do material usado. Toda a artesanalidade contida no universo da madeira, da tinta, ou da pedra persiste no espaço público, na democracia, ou no efêmero aqui analisados. A habilidade na confecção de pormenores físicos não é abandonada na elaboração conceitual. Entretanto, o desejo de que o imaterial seja qualquer coisa além do que é, objeto não tangível, alimenta ilusões de hierarquias e de mudança radical de paradigmas. É possível, portanto, problematizar a ideia de "efêmero" tanto nas obras materiais quanto nas obras imateriais, quando esta distinção por componentes de qualidades diferentes é aplicada. 
A imaterialidade, componente tradicional nas artes "performáticas" como a música e o teatro, teve sua distinção abalada com o advento dos aparelhos de registro modernos. Particularmente na música, embora existissem meios de registro anteriores — a tablatura, a partitura, a notação neumática ou mesmo a notação grega por letras, são fontes de registro ainda hoje usadas para evocar novamente uma sonoridade perdida no tempo, mesmo que algumas delas tenham alto grau de precariedade,- 0 advento dos reprodutores mecânicos, proporcionando emulação exata de uma performance, agregou complexidade adjetiva sobre as realizações sonoras ao vivo. A recusa do a priori, da obra acabada, replicável, nas performances musicais, portanto, almejava a manutenção do aspecto temporário, efêmero, único de cada evento, evitando assim espelhamento no palco da lógica dos fonogramas, cópias inalteráveis. Exemplo desta crítica, atual ainda hoje, pode ser encontrado nas palavras de Theodor Adorno:

\begin{abstract}
O ideal oficial da interpretação, que predomina em toda parte na esteira do trabalho extraordinário de Toscanini, ajuda a sancionar um estado de coisas que - para usar uma expressão de Eduard Steuermann — pode-se denominar "barbárie da perfeição". [...]. Reina aqui uma disciplina férrea. Precisamente férrea. 0 novo fetiche, neste caso, é o aparato como tal, imponente e brilhante, que funciona sem falha e sem lacunas, no qual todas as rodas engrenam umas nas outras com tanta perfeição e exatidão que já não resta a mínima fenda para a captação do sentido do todo. A interpretação perfeita e sem defeito, característica do novo estilo, conserva a obra a expensas do preço da sua coisificação definitiva. Apresenta-a como algo já pronto e acabado desde as primeiras notas; a execução soa exatamente como se fosse sua própria gravação no disco. A dinâmica é de tal forma predisposta e pré-fabricada, que não deixa espaço algum para tensões (ADORNO, 1985, p.85).
\end{abstract}

Adorno direciona sua crítica ao novo fetiche da música, o performer, instrumentista ou regente, identificando aquilo que seria efêmero, o som, como coisa, objeto pré-fabricado. Obviamente, um dos materiais da performance é o som, mas aquilo que Adorno considera realizado de antemão e replicável infinitas vezes é chamado de "interpretação" ou conjunto de decisões sobre articulação, tempo, dinâmica, timbre, fraseado e digitações que orientam cada apresentação. Existe, portanto, uma clara distinção entre a obra e seus diversos componentes em que a sonoridade - material de qualidade efêmera - figura ao lado de tantos outros no projeto, plano, roteiro, ou, interpretação da peça. É, certamente, incômodo visualizar uma performance instrumental como trabalho permanente, reiterável de maneira estática, entretanto, evocando outra figura do universo musical, tem-se um exemplo igualmente radical. Para Milton Babbitt, do ponto de vista de um compositor, a obra musical é projeto, pesquisa, ideia, plano, em que o som atua como mera materialização. Em Who Cares If You Listen? (BABBITT, 1998), o autor evoca a natureza abstrata e especialista do pensamento musical para argumentar a inevitabilidade e necessidade de afastamento do público geral, tal como acontece com físicos, matemáticos e filósofos. A autonomia e complexidade do desenvolvimento composicional 
estariam ameaçadas pelo comprometimento social em que o instrumentista, na maioria das vezes, inconsciente das novas demandas, é substituído por meios eletrônicos de reprodução, e o ouvinte, reduzido apenas aos poucos especialistas.

\begin{abstract}
Eu digo tudo isso não para apresentar um retrato de uma música virtuosa diante de um mundo criminoso, mas para apontar o problema de uma música especial em um mundo estranho e deslocado. E, sendo assim, eu ouso sugerir que o compositor deveria fazer um serviço imediato e eventual a si mesmo e à sua música retirando-se total, resoluto e voluntariamente deste mundo público para um de performance privada e por mídia eletrônica, com sua real possibilidade de eliminação completa dos aspectos públicos e sociais da composição musical (BABBITT, 1998, p.249).
\end{abstract}

Tanto Adorno quanto Babbitt, por razões opostas, enfatizam a natureza permanente da música. Para Adorno, a repetição das mesmas interpretações, coisificadas, revelam o desejo de espelhamento dos novos fonogramas. 0 tratamento das consequências da pressão sobre 0 instrumentista para renovar constantemente seu projeto interpretativo, como visualizável em Adorno, não será exaustivamente abordado aqui, mas merece um arremate. É notável dentre outras categorias de artistas como compositores, artistas visuais e escritores, a naturalização recorrente de um objeto final, estável, acabado, não refeito, ou coisificado, a ser reapresentado tal como sempre foi, o que leva a entender a necessidade de reestruturação constante da obra de interpretação daquele que toca, no mínimo, fruto de incompreensão de suas premissas artísticas. No caso de Adorno, portanto, a exigência de renovação da obra performática poderia ser problematizada, mas o que interessa neste momento é registrar o argumento contundente de que há uma obra performática reiterável ou objetificada por parte do instrumentista. Por outro lado, o pensamento de Babbitt pretende preservar 0 controle, as estruturas determinadas pelo artista compositor, e não aquelas elaboradas pelo artista instrumentista-intérprete. A substituição do humano-criativo por um aparelho, portanto, garantiria o controle e a permanência da obra idealizada no projeto. Na música, esta premissa de pré-existência da obra, anterior à sua materialização em som, não é nova, e pode ser encontrada nas palavras do analista Heinrich Schenker já na segunda década do século XX, atestando a existência e persistência das obras sonoras, inconsistentemente chamadas de efêmeras:

Basicamente, uma composição não requer uma performance para existir. Como um som imaginado parece real à mente, a leitura de uma partitura é suficiente para provar a existência da composição. A reprodução mecânica da obra, portanto, pode ser considerada supérflua (SCHENKER, 2000, p.3).

$\mathrm{O}$ argumento empreendido por muitos trabalhos, especialmente os work in progress, de que a performance nunca é repetida porque cada momento de execução é único não é levado em consideração nesse caso nem quando os diferentes ambientes são meramente cenário, nem quando 
compõem o universo da obra. Um truque de mágica, na rua, em Las Vegas, ou em um programa de TV, é essencialmente o mesmo, apesar de adotar participantes ou lugares diferentes. De modo mais incisivo e dramático, a adoção do momento da execução da obra e de sua fruição pelo espectador como componentes da obra traria complexidades extras para o tratamento do "efêmero" levando a conclusões ainda menos favoráveis neste quesito aos trabalhos que pretendem ser diferenciados pela sua duração. Caso estes componentes sejam adotados como elementos temporais-precários participantes da obra, todas as obras se beneficiariam desta premissa, inclusive aquelas consideradas permanentes. Se, em cada fruição, há a renovação dos elementos da obra, em um processo advogado por Jorge Luis Borges para os leitores de seus textos e defendido por Umberto Eco (1971) como primeiro grau de abertura das obras de arte acabadas, mesmo as obras tidas tradicionalmente como permanentes poderiam ter sua existência "elevada" ao grau temporário, partindo do pressuposto de irrepetibilidade de cada momento e considerando que essas obras fixas existem e são modificadas quando visualizadas.

Ao confrontar, portanto, a irrelevância da qualidade de um dos componentes da obra, seja na arte do instrumentista ou naquela do compositor, trazida por Adorno, Babbitt e Schenker, respectivamente, para a determinação da permanência do projeto, plano, ideia, partitura ou interpretação - em que um material, o som, é transitório, mas todos os demais são permanentes fica clara a precariedade na determinação do "efêmero" a partir do tipo de elemento usado para estruturar a obra, como apresentada por Phillips e amplamente replicado por outros. Se, como defendem Adorno e Babbitt, a obra é mais projeto, ou simplesmente projeto, como quer Schenker, prescindindo de sua materialização física, sua permanência, seja ela composta de gelo, de ato, luz ou som, está garantida e determinada pelo script. Seria impossível uma arte efêmera? Neste ponto, uma classificação que leve em conta a relação da obra com o tempo poderia ser mais apropriada. A arte efêmera, portanto, em que o temporário, a partir de agora, é qualidade restrita aos materiais e não mais à obra como um todo, tem por característica sua curta duração e sua irrepetibilidade. Ambas as qualidades são necessárias às obras que se pretendem efêmeras uma vez que, se tiverem longa duração, estariam ao lado das obras tradicionalmente consideradas permanentes, enquanto que, se repetidas, enquadrar-se-iam na noção de permanência enquanto projeto anteriormente mencionada ${ }^{356}$.

356 Cristiano Sousa dos Santos, gentilmente, indicou a bibliografia e revisou com maestria as aproximações com o debate no campo musical. 


\subsection{Tranquilidade e intranquilidade temporárias}

No discurso de Patricia Phillips, na primeira das suas citações apresentadas, "tranquilo" e "rotina" são outros adjetivos usados para qualificar o "efêmero" no espaço privado, supondo dois pressupostos de distinção, por seus opostos, frente à temporalidade no espaço público: o primeiro, relativo ao volume de som dos eventos, oposto a "tranquilo", e o segundo, contrário à "rotina", diz respeito à maior quantidade e variedade de eventos. Nenhum deles parece apropriado ao conceito de efemeridade na medida em que um evento não é breve ou duradouro se tiver volume mais ou menos elevado ou tiver ocorrência em maior ou menor quantidade - tal como debatido no tópico anterior a qualidade do material e sua proliferação não garantem a efemeridade. Mesmo assim, a ideia de efêmero, portanto, foi incorporada ao vocabulário artístico vinculada a dois pressupostos, um, promotor de ruído, e outro, associado ao caos. Ambos, característicos do cenário contemporâneo, mapeados pelos comentários pós-modernos, formam um pacote, quase um ready made conceitual, pronto para ser transposto ao processo criativo da obra. Dentre os trabalhos apresentados no $8^{\circ}$ Salão Bienal do Mar, aqueles envolvidos diretamente com o debate do turbilhão do espaço público foram O Silêncio do Martelo, com sua manipulação de objetos descartados nas ruas e desmonte da própria obra por estar no espaço selvagem das ruas, Atenção: Arte, pelo conteúdo denunciatório de suas mensagens sobre 0 desregramento público, e Nós vemos a cidade como a cidade nos vê, em que há a evocação das múltiplas faces ou visões do espaço público e de seus usuários.

Outras duas qualidades atribuídas ao espaço público contemporâneo são mencionadas por Phillips no mesmo trecho selecionado. "Mutabilidade" e "inquietude" são elementos associados como potencializadores do efêmero ou mesmo confundidos com ele. A relação entre modificação e o espaço público apresenta problemas na medida em que a metamorfose é qualidade quase onipresente no universo — rios, mar, florestas, desertos, não são espaços urbanos, porém presenciam reestruturação permanente - , sendo difícil especificar local ou tempo em que sua presença é maior ou menor, o que tornaria seu vínculo com o espaço público mais um capricho de arremate para a confecção do pacote conceitual do efêmero. Semelhante conclusão pode ser obtida com a análise da relação entre "modificação" e "efêmero" na medida em que, embora muito semelhantes, não constituem conceitos idênticos. Assim, "mudança", ou "existência modificada", pode ser entendida como mais um traço contextual de efêmero, ou "existência não duradoura", e, embora possa haver uma discussão filosófica mais apropriada sobre a real diferença entre ambos os conceitos, é certo que há uma utilização vinculada no vocabulário de arte no espaço urbano. "Inquietude", por sua vez, é outro traço típico do frenesi contemporâneo, amplificado pela ideia de proximidade e velocidade constituídas em mudanças nos sistemas de comunicação de massa e transporte local e global, a ser agregado ao pacote 
conceitual efêmero em sua versão século XXI — embora com vínculo artificial já que o "inquieto" pode ser duradouro. Nesse sentido, dentre os trabalhos do $8^{\circ}$ Salão Bienal do Mar, aqueles que apresentaram características metamórficas marcantes foram O Silêncio do Martelo - recolhido logo depois de sua realização -, Marí(n)timo - pela retirada de peças bibliográficas da biblioteca nos pontos de ônibus -, Folhetim Sereia - pelo vaguear translúcido dos passantes pelos vitrais dos pontos de ônibus -, Caminho das Águas - pelo desgaste ou sobreposição da linha pintada no chão público - e, finalmente, O retorno de Araribóia, pelos passeios ameaçadores da escultura do guerreiro pelas ruas do Centro de Vitória.

A tentativa de fazer do espaço público o ambiente primordial do efêmero, portanto, pouco defensável do ponto de vista racional, parece suprir o desejo de fundar um movimento de retomada do deslumbre com o exterior urbano, em que o transitório, ao lado de seus conceitos agregados, cumpriria, sobretudo, uma função simbólica. O resgate do playground burguês no final do século reflete uma era conectada globalmente seja pelo discurso multicultural, pela proximidade promovida pelo turismo, ou pelas redes virtuais. Contrariando no mundo real o ideal deste movimento, o espaço público, pontos comuns de passagem, de ocupação, a floresta do homem contemporâneo, parece ser um lugar avesso à contemplação, à percepção poética, ao diálogo, apesar de ter sido promovido com entusiasmo como novo espaço expositivo. Velocidade e tensão costumam marcar o andar do transeunte nas cidades grandes, demonstrando os entraves de realização do desejo de participação no movimento de revalorização dos centros urbanos e flagrando a ênfase no abstrato, em detrimento de sua execução, no processo bipartido característico de algumas produções artísticas contemporâneas no espaço urbano. Neste ambiente reativo, portanto, o efêmero, para que possa competir com a multiplicidade de apelos, bem como 0 alerta gerado por todos os riscos que envolvem a aventura fora de ambientes privados ${ }^{357}$, precisaria ser igualmente agressivo, pois, 0 transeunte desenvolveu mecanismos de defesa contra os superestímulos, como já debatido anteriormente. Uma nova estratégia de visibilidade, portanto, levou parte dos trabalhos envolvidos no $8^{\circ}$ Salão Bienal do Mar a adotarem espaços públicos de concentração forçada como componente da obra. Em Marín]timo, de Melina Almada, a obra acontece nos pontos de ônibus, é iniciada quando o cidadão retira um volume disponível na minibiblioteca com temática marítima, e mergulha em itinerário desconhecido. 0 instante perseguido pelo projeto pressupõe, entretanto, a disponibilidade ao sensível que, como já foi dito, não se encontra amplamente disseminada no ambiente público urbano. É assim que a arte pública efêmera revela seu público, seu interlocutor ou, como no caso específico, seu participante/fruidor. 0 cidadão

\footnotetext{
$357 \quad$ Não é à toa que as praças públicas foram sendo substituídas por shoppings, espaços supostamente idílicos de uma utopia urbana de ordem e segurança.
} 
médio, letrado, crente no poder da educação como meio de ascensão social, pode possivelmente se interessar por - após um dia de trabalho no escritório, em pé na sarjeta poluída - aproveitar o interstício ocioso entre o trabalho e o lar para valorizar o seu aparato intelectual ${ }^{358}$. Tão multitarefa quanto seus aparelhos, o homem médio contemporâneo sente culpa quando no ócio e faz do seu dia um conjunto ansioso de instantes sobrepostos.

\subsection{Efêmero: cessão e exceção}

Dentre os elementos complexos e abundantes convocados para legitimar a inserção da arte no espaço urbano nas últimas décadas, a noção de efêmero talvez seja uma das mais evasivas. Álibi poético para saída dos espaços privados, o temporário nas ações institucionalizadas, é um instrumento que torna possível a ocupação das ruas por um período pré-estabelecido pela administração pública, sem provocar transtornos maiores. A remoção da obra de Richard Serra e sua substituição pelo trabalho apaziguador de Martha Schwartz deveriam bastar como exemplo paradigmático de que é tudo que incomoda efetivamente é banido. Assim, para o poder público, a natureza temporária das obras constitui um fator de desoneração para o seu desmonte, transporte, guarda e remontagem, frente à cara permanência das obras tradicionais. Por seu turno, os governantes obtêm a valorização dos potenciais simbólicos de suas cidades, atendendo aos ditames da cartilha da cidade-global, a um excelente custo-benefício. Para eles, a rotatividade proporciona uma variedade cultural dificilmente obtida com a obra permanente. De modo particular, para os artistas, o "efêmero" possibilita não apenas maior facilidade na confecção, transporte, montagem, desmontagem e remontagem das obras, mas também, pela permanência concedida como projeto, plano, partitura ou script, uma onipresença recursivamente revigorada da obra.

O incômodo provocado pela replicação, coisificação, ou reprodução das obras efêmeras não é estancado pela alegação de que cada momento de apresentação é único, uma vez que essa imprevisibilidade está dada de antemão pela proposta do projeto. Adotando, portanto, uma perspectiva adorniana, as obras de arte no espaço público têm feito réplicas de si mesmas, na esperança de perpetuação de uma ideia em diferentes momentos e espaços. De modo mais contundente, esta ideia,

\footnotetext{
$358 \quad$ Nesse sentido, é interessante resgatar o relato de Nicolau Sevcenko que viveu durante muitos anos no bairro operário da Vila Prudente na zona Leste de São Paulo. Segundo afirmou o historiador em entrevista, ao ingressar na Universidade de São Paulo, aproveitava as quatro ou cinco horas por dia dentro de um ônibus para fazer suas leituras e preparar suas aulas, o que o levou a se adaptar a ler no ônibus, acrescentando, entretanto, que foi "[...] uma ideia péssima, porque a vibração, o movimento provoca o deslocamento da retina. Nem gosto de pensar no dano que eu causei para as minhas vistas, hoje abaladíssimas, por conta da vida de viver lendo dentro de ônibus" (KANASIRO, Alvaro Katsuaki; HIRANO, Luis Felipe Kojima. Entrevista com professor Nicolau Sevcenko. Ponto Urbe (Online), 102012, posto online no dia 26 Julho 2014). Disponível em: <https://pontourbe.revues.org/1325>. Acesso em: 20 jan. 2017.
} 
multiplicada e eternizada, é reivindicada e renovada pela constituição efêmera de seu material e, assim, outorgada à noção de "ineditismo" tão cara à tradição artística modernista.

Adotado como estandarte artístico, o ineditismo, um dos componentes fundamentais do conceito de "obra-prima", pelo menos em viés modernista, diretriz primeira da historiografia da disciplina, é potencializado no culto contemporâneo por meio do modelo conceitual do "efêmero" e suas alegações renovatórias de espaço, material e participantes. Este é um dos tributos pagos pela era pósmoderna, de textura pastosa, à tradição disciplinar da arte. Outro resquício mantido na maioria dos casos é a obra como objeto, mesmo que na nova forma de projeto, cujo termo "processo", ou work in progress, é alimentado diretamente pelo conceito de "efêmero", ao mesmo tempo em que habilita a ideia de ineditismo constante. Este discurso da arte contemporânea mantenedor da obra como objeto e rastreadora implacável do ineditismo, se auto-reivindica imaterial, muito embora, para a ampla maioria dos casos, esta intangibilidade esteja circunscrita à natureza de seus componentes e não à metodologia de criação em si - não é à toa que o registro do processo tenha assumido uma premência inédita, igualando-se, na prática, à importância de suas próprias execuções. Portanto, o "efêmero", tal como adotado em diversos discursos das práticas contemporâneas, catalisa a mesmo tempo elementos tradicionais, obra e ineditismo, bem como azeita a produção com a imaterialidade própria dos novos tempos, de fato não tão líquidos como se gostaria de acreditar.

Neste cenário exótico, promovido pela busca de novos materiais, novos espaços e nova visibilidade, o "efêmero" é uma espécie de novo local fictício de possibilidades variadas para a criação artística em que se ancoram suas expectativas e inquietações. Há quem diga que essa prerrogativa, com amplo espaço de visibilidade, fortunas de vias, momentos inéditos e irrecuperáveis, seria ainda mais extraordinária na esfera pública da internet. Entretanto, o mero deslocamento, troca de materiais não necessariamente consiste de renovação metodológica. É provável, portanto, que a associação entre arte contemporânea e efemeridade seja mais tradicional do que seu discurso e espelho almejam. 


\section{REFERÊNCIAS}

ACQUARONE, Francisco. História das Artes Plásticas no Brasil. (Atualizada por Leda Acquarone de Sá) Rio de Janeiro: Edição do atualizador, 1980.

ADORNO, Theodor W. O fetichismo na música e a regressão da audição. In: Adorno - vida e obra. São Paulo: Editora Nova Cultural, 2005.

ALBERRO, Alexander. Periodising Contemporary Art (2011). Disponível em: $<$ http://www.globalartmuseum.de/site/guest_author/306>. Acesso: 19 abr. 2014.

ALBUQUERQUE, Fernanda Carvalho de. Troca, soma de esforços, atitude crítica e proposição: Uma reflexão sobre os coletivos de artistas no Brasil (1995 a 2005). Dissertação (Mestrado em Artes Visuais) Instituto das Artes, Universidade Federal do Rio Grande do Sul, Porto Alegre, 2006.

ALVES, Henrique. Cegos de tanto ver. Século Diário. Nov. 2006. Disponível em: <http://www.seculodiario.com.br/arquivo/2006/novembro/21/cadernoatracoes/cultura/01.asp>. Acesso em: 20 mai. 2017.

ALVES, José Francisco. (Org.). Experiências em Arte Pública: Memória e Atualidade. Porto Alegre: Artfolio e Editora da Cidade, 2008.

AMARAL, Aracy (Org.). Correspondência Mário de Andrade \& Tarsila do Amaral. São Paulo: EDUSP, 2003.

ANJOS, Moacir dos. Dinamismo e Crise dos Museus de Arte no Brasil. Revista Z Cultural (UFRJ), v. 1, 2006.

ARIZA, Adonay. A moda como arte. In: MARGOTTO, Samira (Org.). Catálogo do $7^{0}$ Salão do Mar. Vitória: SEMC/PMV, 2006b.

BABBITT, Milton. Who cares if you listen? In: SCHWARTZ, Barney Childs Elliott; FOX, James (Ed.). Contemporary Composers on Contemporary Music. [S.I.]: Da Capo Press, 1998.

BALESTRERI, Silvia. Verdade e ética no teatro invisível. Anais do Simpósio da International Brecht Society, vol.1, 2013. Disponível em: <https://www.ufrgs.br/ppgac/wp-content/uploads/2013/10/Verdade-e-\%C3\%A9ticano-Teatro-Invis\%C3\%ADvel.pdf>. Acesso em: 14 dez. 2016.

BARBOSA, Ana Mae; FERRARA, Lucrécia D'Alessio; VERNASCHI, Elvira (Orgs.). 0 Ensino das Artes nas Universidades. São Paulo: EDUSP, 1993.

Ana Mae (Org.). Ensino da arte: memória e história. São Paulo: Perspectiva, 2008.

Ana Mae. Teoria e prática da educação artística. São Paulo: Cultrix, 1975.

BATISTA, Lourival. Cinco atos criminosos que participei e que talvez possam ser chamados arte. Recife: Revista Tatuí. Edição 02, maio de 2007.

BAUDRILLARD, Jean. À sombra das maiorias silenciosas: o fim do social e o surgimento das massas. Tradução de Suely Bastos. São Paulo: Editora Brasiliense, 1985. 
BAY, Pirate. About. n/i. Disponível em: <https://thepiratebay.org/about>. Acesso em: 15 jun. 2017.

BISHOP, Claire. Artificial Hells: Participatory Art and the Politics of Spectatorship. New York: Verso, 2012.

Claire. A virada social: colaboração e seus desgostos. Tradução de Jason Campelo. Concinnitas, ano 9, volume 1, número 12, julho 2008.

, Claire. Antagonism and relational aesthetics. October. N.110, fall 2004, pp. 51-79. Disponível em: <http://academicworks.cuny.edu/cgi/viewcontent.cgi?article=1095\&context=gc_pubs>. Acesso em: 20. Mai. 2017.

Claire. (Ed.). Participation. Cambridge: Massachusetts: MIT Press, 2006.

BLOCH, Marc. Apologia da História ou o Ofício do Historiador. Prefácio de Jacques Le Goff; Apresentação à edição brasileira de Lilia Moritz Schwarcz. Tradução de André Telles. Rio de Janeiro: Jorge Zahar, 2001.

BOTTALLO, Marilúcia. Arte moderna e contemporânea em São Paulo: o museu como intermediário. 2001. Dissertação (Mestrado em Comunicações e Artes) - Escola de Comunicações e Artes/USP, São Paulo, 2001.

Marilúcia. Humanidades em Trânsito. In: RUFINONI, Priscila, MARGOTTO, Samira. $8^{\circ}$ Salão Bienal do Mar: ondas, pontes e intervenções navegáveis. Vitória: SEMC/PMV, 2009b.

BORGES, Fabiane Moraes. Domínios do Demasiado. Dissertação (Mestrado em Psicologia Clínica) - Pontifícia Universidade Católica de São Paulo, São Paulo, 2006.

BOURDIEU, Pierre. As regras da arte: gênese e estrutura do campo literário. Tradução de Maria Lúcia Machado. São Paulo: Companhia das Letras, 1996.

BOURRIAUD, Nicolas. Estética Relacional (1998). Tradução de Denise Bottmann. São Paulo: Martins, 2009.

BRASIL. Lei $n^{0}$ 8.029, de 12 de abril de 1990, extingue a Fundação Nacional de Artes - Funarte. Disponível em: <http://www.funarte.gov.br/acessoainformacao/institucional/>. Acesso em: 20 mai. 2017.

BRASIL. Lei 5.962, de 11 de agosto de 1971, Diretrizes e Bases de $1^{\circ}$ e $2^{\circ}$ graus. Ministério da Educação e Cultura. Conselho Nacional de Educação.

BRASIL. Lei № 9.394, de 20 de dezembro de 1996. Ministério da Educação e Cultura.

CAÇADOR, Sávio B.; GRASSI, Antonio. A evolução recente da economia do Espírito Santo: um Estado desenvolvido e periférico?. In: FERRARI, Marcos Adolfo Ribeiro, ARTHMAR, Rogério. Novas leituras sobre a economia do Espírito Santo, Vol.1. Vitória: PPGEco/CORECON-ES, 2011.

CATALOGO DO 11 SALÃO DA BAHIA. Salvador: Museu de Arte Moderna da Bahia. 04-12-2004 a 23-01-2005.

CAVALCANTI, Raíza Ribeiro. Agenciamentos artísticos: uma análise sociológica sobre a ação dos trabalhos artísticos no interior do campo da arte brasileiro. 2016. Tese (Doutorado em Sociologia) - Universidade Federal de Pernambuco. Recife, 2016.

CAYRES, Ludmila. $\quad \mathrm{Eu} \quad$ tbm!!! $2004 . \quad$ Disponivel em: <https://br.groups.yahoo.com/neo/groups/paralelaaomar/conversations/messages/16>. Acesso em: 10 abr. 2017.

CHARTIER, Roger. Cultura popular: revisitando um conceito historiográfico. Estudos Históricos. Rio de Janeiro, vol. 8, n. 16, 1995, p.179-192. 
CARNEIRO, Ricardo. O desenvolvimento brasileiro pós-crise financeira: oportunidades e riscos. Observatório da economia global. №4, agosto de 2010.

CIRILLO, Aparecido José. Relatório da Ação Educativa do $7^{\circ}$ Salão do Mar. Vitória: LEENA; SEMC/PMV, 2006.

Aparecido José; MENDES, Neusa (Org.). Atenção arte: doze obras efêmeras e uma permanente (Obra não publicada, organizada em 2009a).

Aparecido José; MENDES, Neusa. Cidade, intervenção urbana e arte pública: $8^{a}$ Bienal do Mar. Anais do I Seminario Internacional sobre arte publico en Latinoamérica. Buenos Aires: UBA, 2009b, vol. I, pp. 163168.

COCCHIARALE, Fernando. Abstracionismo geométrico e informal: a vanguarda brasileira nos anos cinquenta. Rio de Janeiro: FUNARTE, 1987.

CONTRAINDICACIONES. Convocatoria de proyectos de arte público. MADRID ABIERTO 2007. 2006. Disponível em: <https://contraindicaciones.net/convocatoria_de_proyectos_de_a_1/>. Acesso em: 20 mai. 2017.

CYPRIANO, Fabio. Bourriaud analisa artes plásticas sem temor nem preconceito. São Paulo: Folha de S. Paulo, 16 de maio de 2009. Disponível em: <https://www1.folha.uol.com.br/fsp/ilustrad/fq1605200910.htm>. Acesso em: 16 jul. 2018.

DEUTSCHE, Rosalyn. Art and Public Space: Questions of Democracy. Social Text. Duke University Press. №. 33 [1992], pp.34-53.

DIEZ, Jorge. Madrid abierto. Disponível em: <http://madridabierto.com/textos/2011-2012/10-anos-madridabierto.html>. Acesso em: 19 dez. 2017.

DUBY, Georges. Guilherme Marechal, ou o melhor cavaleiro do mundo. Rio de Janeiro: Graal, 1987.

DUMBADZE, Alexander and HUDSON, Suzanne (Ed.). Contemporary art: 1989 to the present. John Wiley \& Sons, Inc., 2013.

ECO, Umberto. Obra Aberta. Tradução de Pérola de Carvalho. [S.I.]: São Paulo: Perspectiva, 1971.

FARIAS, Agnaldo (Entrevista concedida à Alexandre Nicolidi e Denis Nicola). A política na arte através da arte política. Revista Panorama Crítico (online), v. 08, 15 out. 2010. Disponível em: <http://www.panoramacritico.com/008/entrevistas_02.php>. Acesso em: 10 abr. 2017.

Agnaldo. Faxinal das Artes no Faxinal do Céu (2002). In: FERREIRA, Glória. Crítica de arte no Brasil: temáticas contemporâneas. Rio de Janeiro: Funarte, 2006a.

Agnaldo. Os exemplos de dois museus japoneses. In: Rumos Artes Visuais Itaú Cultural 2005-2006. São Paulo: Itaú Cultural, 2006b.

Agnaldo. Quando a arte se lança à avenida. In: RUFINONI, Priscila, MARGOTTO, Samira. $8^{\circ}$ Salão Bienal do Mar: ondas, pontes e intervenções navegáveis. Vitória: SEMC/PMV, 2009c.

Agnaldo. Convite à viagem. In: MARGOTTO, Samira (Org.). $7^{\circ}$ Salão do Mar. Vitória: Secretaria Municipal de Cultura/ Casa Porto das Artes Plásticas, 2006d.

FABRIS, Annateresa. Portinari: pintor social. São Paulo: Perspectiva: Universidade de São Paulo, São Paulo, 1990. 
Annateresa (Org.). Modernidade e Modernismo no Brasil. Campinas: Mercado das letras, 1994.

FERNÁNDEZ, Maria Dolores Arroyo. Arte en la calle: Evolución del concurso internacional Madrid Abierto en el periodo 2004-2007. Arte y Ciudad: Revista de Investigación. № 2, Octubre de 2012, pp. 87-97. Disponível em: <http://arteyciudad.com/revista/index.php/num1/article/view/74/129>. Acesso em: 20 mai. 2017.

FERREIRA, Gloria. Crítica de arte no Brasil: temáticas contemporâneas, 2006.

FERREIRA, João Sette Whitaker. São Paulo: 0 mito da cidade global. Tese (Doutorado em Estruturas Ambientais Urbanas). Faculdade de Arquitetura e Urbanismo/USP, São Paulo, 2003.

FERREIRA, Paula Scamparini. Legitimação e mediação da arte: projeções no contemporâneo. 2006. Dissertação (Mestrado) - Universidade Federal do Rio de Janeiro, Rio de Janeiro, 2006.

FIGUEIREDO, Luciano (Ed.). Lygia Clark - Hélio Oiticica - Cartas - 1964-74. Rio de Janeiro: Editora UFRJ, 1998.

FIX, Mariana. São Paulo cidade global: fundamentos financeiros de uma miragem. São Paulo: Boitempo, 2007.

FLUSSER, Vilém. Da Ironia. Publicado originalmente na Folha de S. Paulo, em 26-02/1972. Disponível em: <http://textosdevilemflusser.blogspot.com.br/2008/08/da-ironia.html>. Acesso em: 08 nov. 2016.

FOSTER, Hal. Bad New Days: Art, Criticism, Emergency. London/New York: Verso Books, 2015.

FOUCAULT, Michel. Vigiar e punir: nascimento da prisão. Tradução de Raquel Ramalhete. 29 ed. Petrópolis: Vozes, 2004.

, Michel. Microfísica do poder. São Paulo: Graal, 2005.

, Michel. Uma entrevista com Stephen Riggins (1982): sexo, poder e a política da identidade. Tradução de Wanderson Flor do Nascimento. São Paulo: PUC. Verve: Revista semestral autogestionária do Nu-Sol. $\mathrm{n}$. $5,2004$.

GINZBURG, Carlo. 0 queijo e os vermes: 0 cotidiano e as ideias de um moleiro perseguido pela Inquisição. Tradução de Maria Betânia Amoroso. São Paulo: Companhia das Letras, 2006.

GNU History. 2016. Disponível em: <https://www.gnu.org/gnu/gnu-history.html>. Acesso em: 29 abr. 2017.

GRESSEL, Katherine. Participatory Public Art Evaluation: Approaches to Researching: Audience Response. In: McCLELLAN, Andrew (Ed.). Art and its Publics: Museum Studies at the Millennium. London: Blackwell Publishing, 2004.

GROYS, Boris. Art Power. London: The MIT Press, 2008.

GRUMAN, Marcelo. Incentivos Fiscais para as Artes: balanço histórico e perspectivas futuras. II Seminário Internacional de Políticas Culturais, 2011.

Marcelo. Nem tanto ao céu, nem tanto a terra: limites e possibilidades da lei de incentivo fiscal à cultura. Revista Espaço Acadêmico, v. 9, n. 107, p. 149-154, 2010.

GUTTENBERG, Project. Gutenberg: The History and Philosophy of Project Gutenberg by Michael Hart. 1992. Disponivel <https://www.gutenberg.org/wiki/Gutenberg:The_History_and_Philosophy_of_Project_Gutenberg_by_Michael_H art>. Acesso em: 29 abr. 2017. 
HARTOG, François. Regimes de Historicidade: presentismo e experiências do tempo. Tradução de Andréa Menezes, Bruna Beffart, Camila Moraes, Maria Cristina Silva e Maria Helena Martins. Belo Horizonte: Autentica, 2013.

HUYSSEN, Andreas. Seduzidos pela memória: arquitetura, monumento, mídia. Tradução Sérgio Alcides. 2. ed. Rio de Janeiro: Aeroplano, 2004.

Andreas. Memórias do Modernismo. Rio de Janeiro: UFRJ, 1997.

Andreas. Mapeando o pós-moderno. In: HOLLANDA, Heloisa Buarque de (Org.). Pós-modernismo e política. Rio de Janeiro: Rocco, 1992.

IFEMA. Arco Madrid. Disponível em: <http://www.ifema.es/arcomadrid_01/>. Acesso em: 20 mai. 2017.

JACQUES, Paola Berenstein. Errâncias Urbanas: a arte de andar pela cidade. Arqtexto, Porto Alegre, v. 7, p.1625, 2005.

JAREMTCHUK, Dária. Anna Bella Geiger: passagens conceituais. São Paulo: Editora da Universidade de São Paulo / Belo Horizonte: Editora C/Arte, 2007a.

Dária. Ações políticas na arte contemporânea brasileira. Concinnitas. Ano 8, v. 1, n.10, julho 2007b.

Dária. Solilóquios sobre o mar. In: MARGOTTO, Samira (Org.). $7^{\circ}$ Salão do Mar. Vitória: Secretaria Municipal de Cultura/ Casa Porto das Artes Plásticas, 2006.

KANASIRO, Alvaro Katsuaki; HIRANO, Luis Felipe Kojima. Entrevista com professor Nicolau Sevcenko. Ponto Urbe (Online), 102012, posto online no dia 26 Julho 2014). Disponivel em: <https://pontourbe.revues.org/1325>. Acesso em: 20 jan. 2017.

KESTER, Grant. Conversation Pieces: The Role of Dialogue in Socially-Engaged Ar. Theory in Contemporary Art Since 1985, 2004.

KNIGHT, Cher Krause; SENIE Harriet F. (Edited). A Companion to Public Art. John Wiley \& Sons, 2016.

KWON, Miwon. One place after another: site-specific art and locational identity. Cambridge, Mass; London: MIT Press, 2002.

LAMBLIN, Bernard. Le paysage. In: Peinture et temps. Paris: Kincksieck, 1983.

LATOUR, B. and WEIBEL, P. (Eds.). Making things public: atmospheres of democracy. Cambridge, Mass.: MIT Press, 2005.

LEHMANN, Hans-Thies. Teatro pós-dramático. Tradução de Pedro Süssekind. São Paulo: Cosac \& Naify, 2007.

LIPPARD, Lucy. Six Years: The Dematerialization of the Art Object from 1966 to 1972. New York: The University of California Press, 1973.

Lucy R. Curating by numbers. Tate Papers, v. 12, 2009. Disponível em: <http://www.tate.org.uk/research/publications/tate-papers/12/curating-by-numbers>. Acesso em: 10 abr. 2017.

Lucy; CHANDLER, John. A desmaterialização da arte. Tradução de Fernanda Pequeno e Marina P. Menezes de Andrade. Rio de Janeiro: Arte \& ensaios. Revista do PPGAV/EBA/UFRJ, maio de 2013. 
LOURENÇO, Maria Cecília França. Alargamento do conceito de Objeto: sonhos modernistas. Revista ARA, São

Paulo, n. 1, p. 75-95, oct. 2016. ISSN 2525-8354. Disponível em: <http://www.revistas.usp.br/revistaara/article/view/121780>. Acesso em: 02 nov. 2017.

MAIO, Fernanda. A encenação da arte. Leiria: Textiverso Ltda, 2011.

MARCUSCHI, L.A. \& XAVIER, A.C. (Orgs.). Hipertextos e gêneros digitais. Rio de Janeiro: Lucerna, 2004.

MARGOTTO, Samira. Nos meandros de tempos convergentes, divergentes e paralelos. Santa Maria [RS], ANPAP, 2015. Disponível em: <http://anpap.org.br/anais/2015/simposios/s10/samira_margotto.pdf>. Acesso em: 20 mai. 2017.

Samira. Cousas Nossas: pintura de paisagem no Espírito Santo: 1930-1960. Vitória: EDUFES, 2004.

Samira (Coord.). Relatório do $7^{\circ}$ Salão do Mar. Vitória: SEMC/PMV, $2006 a$.

Samira (Org.). $7^{0}$ Salão do Mar. Vitória: Secretaria Municipal de Cultura/ Casa Porto das Artes Plásticas, 2006b.

MARICONDA, Pablo Rubén. Francis Bacon e as marés: a concepção da natureza e o mecanismo. Scientiæ zudia, São Paulo, v. 5, n. 4, p. 501-19, 2007.

MARTINS, José de Souza. Uma sociologia da vida cotidiana: ensaios na perspectiva de Florestan Fernandes, de Wright Mills e de Henri Lefebvre. São Paulo: Editora Contexto, 2014.

McCLELLAN, Andrew (Ed.). Art and its Publics: Museum Studies at the Millennium. London: Blackwell Publishing, 2004.

MENOTTI, Gabriel. Cineclubes piratas: aparatos tradicionais com tecnologia imprópria. Famecos: mídia, cultura e tecnologia, v. 22, n. 3, p. 96-109, jul 2015. Disponivel em: $<$ http://revistaseletronicas.pucrs.br/ojs/index.php/revistafamecos/article/download/20590/13264>. Acesso em: 20 mai. 2017.

MESQUITA, André Luiz. Insurgências poéticas: arte ativista e ação coletiva (1990-2000). 2008. Dissertação (Mestrado) - FFLCH/USP, 2008.

MONACHESI, Juliana. Artes muito contemporâneas. Salões e crítica institucional. Disponível em: $<$ http://www.revistatropico.com.br/tropico/html/textos/1595,1.shl>. Acesso em 25 mar. 2015.

MORAIS, Lívia Santos de. Porto de Vitória: Armazéns do século XX patrimônio industrial e memória do trabalho. 2014. Dissertação (Mestrado em Artes) - Universidade Federal do Espírito Santo, Vitória, 2014.

MOSQUERA, Gerardo. Linguagem internacional?. Tradução de Marcelo Campos. Arte \& Ensaios. Número 10. Rio de Janeiro: PPGAV/EBA/UFRJ, 2003, p.80-83.

MOUFFE, Chantal. Artistic Activism and Agonistic Spaces. Art \& Research. Volume 1. N. 2. Summer 2007. Disponível em: <http://www.artandresearch.org.uk/v1n2/mouffe.html>. Acesso em: 18 out. 2016.

Chantal. Artistic Strategies in Politics and Political Strategies In: Art. E-MISFÉRICA. Dissidência. Vol. 10 | N. 2 - 2013. Disponível em: <http://hemisphericinstitute.org/hemi/pt/e-misferica-102/mouffe>. Acesso em: 16 out. 2015.

Chantal. Por um modelo agonístico de democracia. Rev. Sociol. Polit.. N.25. Curitiba Nov. 2005. pp. 11-25. Disponível em: <http://www.scielo.br/pdf/rsocp/n25/31108.pdf>. Acesso em: 20 mai. 2017. 
OLIVEIRA, Carlos Alberto; DE AZEVEDO, Suami Paula. Analfabetismo digital funcional: perpetuação de relações de dominação? Revista Brasileira de Linguística, v. 15, n. 2, p. 101-112, 2007.

OLIVEIRA FILHO, Francisco Edilberto de. As políticas públicas de cultura no Espírito Santo entre 2007 e 2014. 2014. Dissertação (Mestrado em Teoria e História da Arte do Centro de Artes) - Universidade Federal do Espírito Santo, Vitória, 2014.

OLIVEIRA NETO, Sebastião. Situação Prestes Maia: o processo de colaboração entre artistas, coletivos artísticos e o Movimento Sem-Teto do Centro (MSTC). Ocupação Prestes Maia/São Paulo (2003-2007). Dissertação (Mestrado Interunidades em Estética e História da Arte) - Universidade de São Paulo, São Paulo, 2012.

OLIVERIA, Rita Alves. Bienal de São Paulo: impacto na cultura brasileira. São Paulo Perspec., São Paulo, v. 15, n. 3. p.18-28, Jul. 2001. Disponível em: <http://www.scielo.br/pdf/spp/v15n3/a04v15n3.pdf>. Acesso em: 04 nov. 2017.

OSÓRIO, Luiz Camillo; CHATEAUBRIAND, Gilberto; REIS, Heitor; PEDROSO, Franklin; RIBEMBOIM, Ricardo. $9^{\circ}$ SALÃO MAM-BAHIA. Salvador. MAM/BA, 2002, s/p. Catalogo.

PAPE, Cristina. Paralela. 2004.2 Disponivel em: $<$ https://br.groups.yahoo.com/neo/groups/paralelaaomar/conversations/messages/27>. Acesso em: 13 mai. 2017.

PALLARES-BURKE, Maria Lúcia Garcia. Entrevista com Zigmunt Bauman. Tempo Social, scielo, v. 16, p. 301 325, 06 2004. ISSN 0103-2070. Disponível em: <http://www.scielo.br/scielo.php?script=scil_arttext\&pid=S0103$20702004000100015 \&$ nrm=iso. . Acesso em: 15 mai. 2017.

PASOLINI, Pier Paolo. As últimas palavras do herege: entrevistas com Jean Duflot. Tradução de Luiz Nazário. São Paulo: Brasiliense, 1983.

PEREIRA, Marcelo. Obras "escapam" da galeria e invadem ruas da Cidade Alta. Vitória: A Gazeta, 21-09-2004.

PHILLIPS, Patricia C. Temporality and public art. Art Journal, JSTOR, v. 48, n. 4, p.331, 1989. Disponível em: <http://dx.doi.org/10.2307/777018>. Acesso em: 29 abr. 2017.

Patricia C. The time frame: Encounters with ephemeral public art. In: KNIGHT, Harriet F. Senie Cher Krause (Ed.). A Companion to Public Art. Wiley-Blackwell, 2016.

PRATES, Daniela Magalhães. A alta recente dos preços das commodities. Revista de Economia Política, vol. $27, n^{0} 3$ [107], pp.323-344, julho-setembro/2007.

PREFEITURA MUNICIPAL DE VITÓRIA. Secretaria Municipal de Cultura. Catálogo do $5^{\circ}$ Salão Capixaba do Mar. Vitória: SEMC/Casa Porto das Artes Plásticas, 2003.

PREFEITURA MUNICIPAL DE VITÓRIA. Vitória: SEMC/PMV, 2012, s/p. Disponível em: <http://monumentoscapixabas.com.br/conteudo/uploads/2014/05/Arariboia.pdf>. Acesso em: 20 mai. 2017.

RAMOS, Nuno. Bandeira branca, amor. Em defesa da soberba e do arbítrio da arte. São Paulo: Folha de S. Paulo, llustríssima. 17 out. 2010.

REZENDE, Renato; SCOVINO, Felipe (Ed.). Coletivos. Rio de Janeiro: Circuito, 2010.

ROSA, João Guimarães. Grande Sertão: Veredas. Rio de Janeiro: Ed. Nova Aguilar, 1994. 
ROSAS, Ricardo. Notas sobre o coletivismo artístico no Brasil. Revista Trópico. Disponível em: <http://p.php.uol.com.br/tropico/html/textos/2578,1.shl>. Acesso em: 07 out. 2017.

Ricardo. Notas sobre o coletivismo artístico no Brasil. Trópico, 2003. Disponível em: http://p.php.uol.com.br/tropico/html/textos/2578,1.shl. Acesso em: 10 out. 2015.

RUFINONI, Priscila R. Anos 70: oposições e inserções artísticas. Concinnitas. Rio de Janeiro. Vol. 1, p.156160, 2009a.

, Priscila, MARGOTTO, Samira. $8^{\circ}$ Salão Bienal do Mar: ondas, pontes e intervenções navegáveis. Vitória: SEMC/PMV, 2009b.

SAFATLE, Vladimir. Cinismo e falência da crítica. São Paulo: Boitempo, 2008.

SAINT-HILAIRE, Auguste. Segunda viagem ao Rio de Janeiro a Minas Gerais e São Paulo. Belo Horizonte: Ed. Itatiaia; São Paulo: EDUSP, 1974.

SAMORA, Loureta. Salão Bienal do Mar terá trabalho de artista plástico francês. Disponível em: <http://legado.vitoria.es.gov.br/diario/2008/1212/mar.asp>. Acesso em: 10 ago. 2016.

SANTOS, M. V. S.; TEIXEIRA, B. R. multipliCIDADE: projeto de ações e intervenções urbanas. Vitória: Produção Independente, 2006.

Marcus Vinícius de Souza. Mapeamento do Edifício das Fundações: uma construção estética e poética no espaço. In: Seminário Internacional de Pesquisadores do Processo de Criação, 2007, Vitória. Seminário Internacional de Pesquisadores do Processo de Criação, 2007.

SÃO PAULO. Folha de S. Paulo, 02-10-2010. Disponivel em: <http://www1.folha.uol.com.br/fsp/ilustrad/fq0210201029.htm>. Acesso em: 25 set. 2016.

SCHENKER, Heinrich. The art of performance. [S.I.]: Oxford University Press, 2000.

SCHMITT, Carl. Teologia política. Tradução de Elisete Antoniuk, Belo Horizonte: Del Rey, 2006.

SCHWARZ, Roberto. Cultura e política, 1964-1969. In: 0 pai de família e outros estudos. Rio de Janeiro: Paz e Terra, 1978.

SCHWARCZ, Lilia Moritz. Por uma historiografia da reflexão. In: BLOCH, Marc. Apologia da História ou o Ofício do Historiador. Rio de Janeiro: Jorge Zahar, 2001.

SENIE, Harriet F.. Reframing Public Art: audience use, interpretation, and appreciation. In: McCLELLAN, Andrew (Ed.). Art and its Publics: Museum Studies at the Millennium. London: Blackwell Publishing, 2004.

SERRA, Richard. Writings Interviews. MIT Press, 1994. In: FUREGATTI, Sylvia. Arte e meio urbano: elementos de formação da estética extramuros no Brasil. 2007. Tese (Doutorado) - FAU/USP, 2007.

SKIDMORE, Thomas. Brasil: de Getúlio Vargas a Castelo Branco (1930-1964). Rio de Janeiro: Editora Saga, 1969.

SMITH, Terry. The State of Art History: Contemporary Art. Art Bulletin. Vol. XCII, n. 4. December 2010, p.366383.

SMITHSON, Robert. Atopia cinemática. Caderno Sesc Videobrasil/SESC-SP, Associação Cultual Videobrasil, v. 3, n.3, p.66-73, 2007. 
SOARES, Miro. Horizonte recortado, para localidades não-litorâneas. Série Deslocamentos Impossíveis, 2006.

SOUZA, Gabriel Girnos Elias de. Percepções e Intervenções na Metrópole: a experiência do Projeto Arte/Cidade em São Paulo (1994/2002). 2006. Dissertação (Mestrado em Engenharia) - Escola de Engenharia de São Carlos, São Carlos/SP, 2006.

STALLABRASS, Julian. Art Incorporated: The Story of Contemporary Art. Oxford: Oxford University Press, 2004.

SÜSSEKIND, Flora. Literatura e vida literária: Polêmicas \& retratos. Rio de Janeiro: Zahar, 1985.

TEIXEIRA, Bernadette Rubim. Galeria Homero Massena: interfaces entre políticas públicas estaduais e as artes visuais no Espírito Santo. 2009. Dissertação (Mestrado em Artes) - Universidade Federal do Espírito Santo, Vitória, 2009.

VALDATI, Nilcéia. É tudo verdade! Testemunho e experiência em 0 prisioneiro da grade de ferro (autorretratos). Crítica Cultural - Critic, Palhoça, SC, v. 10, n. 1, p.109-117, jan./jun. 2015. Disponível em: $<$ http://linguagem.unisul.br/paginas/ensino/pos/linguagem/critica-cultural/1001/100108.pdf>. Acesso em: $10 \mathrm{dez}$. 2016.

VIEIRA JÚNIOR, Erly; RIBEIRO, Célia. Como propor uma ação educativa dentro de uma bienal de intervenção urbana? In: CIRILLO, José Aparecido; MENDES, Neusa (Org.). Atenção arte: doze obras efêmeras e uma permanente. Vitória, 2009b, s/p.

WU, Chin-Tao. Bienais sem fronteiras?. Tradução de Bruno Costa. Novos estudos/ CEBRAP, São Paulo, n. 94, p.109-116, Nov. 2012. Disponível em: <http://www.scielo.br/pdf/nec/n94/n94a05.pdf>. Acesso em: 11 out. 2017.

ZÜGER, Theresa. Re-thinking civil disobedience. Internet Policy Review, v.2, n.4, nov. 2013.

\section{SITES}

BURGUERA, Tania. Disponível em: <http://www.taniabruguera.com/cms/>. Acesso: 12 jul. 2015.

ENTRETANTOS. http://coletivoentretantos.multiply.com/

FOLHETIM SEREIA. Disponível em: fotolog www.fotolog.com/folhetimsereia. Acesso em: 10 fev. 2018.

GANDINI, Marcelo. Fotolog http://fotolog.terra.com.br/marcelogandini.

LEITE, Reginaldo. site http://geocities.yahoo.com.br/rcleitebr/

MARUIPE. Disponível em: <http://maruipe.zip.net/>. Acesso em: 10 dez. 2016.

MARUIPE. Disponível em: <http://www.maruipe.blogger.com.br/>. Acesso em: 10 dez. 2016.

MARUIPE. Disponível em: <http://maruipe.zip.net/>. Acesso em: 28 nov. 2016.

MARUÍPE, 2004. Disponível em: <http://maruipe.zip.net/>. Acesso em 24 set. 2016. 
PINHEIRO, 2004. Disponível em:

<https://br.groups.yahoo.com/neo/groups/paralelaaomar/conversations/messages/2>. Acesso em: 02 jun. 2017.

REGULAMENTO. Regulamento do $14^{\circ}$ Salão da Bahia. Disponível em: $<$ http://www.canalcontemporaneo.art.br/saloesepremios/archives/001421.html. >. Acesso em: 10 nov. 2016.

Disponível em: <http://legado.vitoria.es.gov.br/regionais/bairros/regiao4/saobenedito.asp>. Acesso em: 10 nov. 2016.

Disponível em: <http://www.fotolog.com/antimofo/mosaic/>. Acesso em: 30 out. 2016.

Disponível em: <http://archive.eyebeam.org/people/neurotransmitter>. Acesso em: 30 nov. 2016

Disponível em: <https://br.groups.yahoo.com/neo/groups/paralelaaomar/conversations/messages/50>. Acesso em: 09 mai. 2017.

Disponível em: <http://lattes.cnpq.br/9797455066788577>. Acesso em: 17 ago. 2016.

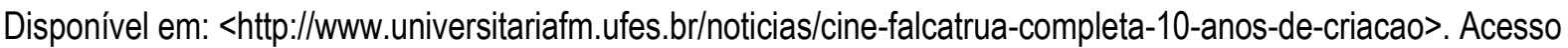
em: 14 dez. 2014.

Disponível em: <https://br.groups.yahoo.com/neo/groups/paralelaaomar/info>. Acesso em: 12 jun. 2016.

Disponível em: <https://br.groups.yahoo.com/neo/groups/paralelaaomar/conversations/messages/3>. Acesso em: 12 jun. 2016.

Disponível em: <https://br.groups.yahoo.com/neo/groups/paralelaaomar/conversations/messages/25>. Acesso em: 09 mai. 2017.

Disponivel em: <https://br.groups.yahoo.com/neo/groups/paralelaaomar/conversations/messages/27>. Acesso em: 20 mai. 2017.

Disponível em: <https://br.groups.yahoo.com/neo/groups/paralelaaomar/conversations/messages/50>. Acesso em: 09 mai. 2017.

Disponível em: <https://br.groups.yahoo.com/neo/groups/paralelaaomar/conversations/messages/73>. Acesso em: 09 mai. 2017.

Disponível em: <https://br.groups.yahoo.com/neo/groups/paralelaaomar/conversations/messages/101>. Acesso em: 09 mai. 2017.

Disponível em: <https://br.groups.yahoo.com/neo/groups/paralelaaomar/conversations/messages/105>. Acesso em: 09 mai. 2017.

Disponível em: <https://br.groups.yahoo.com/neo/groups/paralelaaomar/conversations/messages/107>. Acesso em: 09 mai. 2017.

Disponível em: <https://br.groups.yahoo.com/neo/groups/paralelaaomar/conversations/topics/109>. Acesso em: 09 mai. 2017.

Disponível em: <https://br.groups.yahoo.com/neo/groups/paralelaaomar/conversations/messages/136>. Acesso em: 14 mai. 2017. 
Disponível em: <https://br.groups.yahoo.com/neo/groups/paralelaaomar/conversations/messages/160>. Acesso em: 10 abr. 2017.

Disponível em: <https://br.groups.yahoo.com/neo/groups/paralelaaomar/conversations/messages/162>. Acesso em: 10 abr. 2017.

Disponivel em: <https://br.groups.yahoo.com/neo/groups/paralelaaomar/conversations/topics/163>. Acesso em: 10 abr. 2017.

Disponível em: <https://br.groups.yahoo.com/neo/groups/paralelaaomar/conversations/messages/207>. Acesso em: 16 out. 2016.

Disponível em: <http://www.geocities.ws/rejeitadosnonono/>. Acesso em: 20 mai. 2017.

Disponível em: <http://museuvale.com/site/website/Exposicoes.aspx?id=15\&Page=4>. Acesso em: 20 abr. 2017.

Disponivel em: <http://cultura.estadao.com.br/noticias/geral,linha-imaginaria-faz-mapa-das-artes-no-

brasil,20010104p8695>. Acesso em: 20 abr. 2017.

Disponível em: <https://projetolinhaimaginaria.blogspot.com.br/2010/02/passagem-sob-os-olhos-2000-2001space.html>. Acesso em: 20 mai. 2017.

Disponivel em: http://questoes.blogs.com/>. Acesso em: 02 jul. 2017.

Disponível em: <http://www.artesquema.com/2007/10/30/infelizmente-exposicao-nacional-de-nao-curriculos/>. Acesso em: 25 mar. 2015.

Disponível em: http://www.geocities.ws/rejeitadosnonono/[em cachê]>. Acesso em: 28 mar. 2015.

Disponível em: <https://br.groups.yahoo.com/neo/groups/paralelaaomar/conversations/topics/140>. Acesso em 10 out. 2016.

Disponivel em: <http://www.maruipe.blogger.com.br/>. Acesso em: 12 abr. 2017.

Disponível em: <https://cinefalcatrua.wordpress.com/category/mas-heim/<. Acesso em: 20 jun. 2015.

Disponivel em: <https://casadaxiclet.com/todasexposcoesallexhibitions/>. Acesso em: 08 nov. 2016.

Disponível em: <http://www.fotolog.com/cinefalcatrua/12718803/>. Acesso em: 04 ago. 2016.

Disponivel em: <http://www.universitariafm.ufes.br/sites/default/files/audio/revista_universitaria_23-01-13.mp3>. Acesso em: 14 dez. 2014.

Disponivel em: <http://www.multipliCIDADE2006.com>. Acesso em: 08 out. 2013.

Disponivel em: http://www.itaucultural.org.br/index.cfm?cdl_pagina=2564. Acesso em: 20 mai. 2017.

Disponível em: http://www.iea.usp.br/pessoas/pasta-pessoag/graziela-kunsch>. Acesso em: 20 mai. 2017.

Disponivel em: <http://www.mpaa.org/our-story/>. Acesso em: 21 set. 2016.

Disponível em: < https://pt.wikipedia.org/wiki/Esquema_em_pirl\%C31\%A2mide.>. Acesso em: 10 abr. 2017.

Disponível em: <http://www.artecidade.org.br/indexp.htm>. Acesso em: 10 abr. 2017. 
Disponível em: <http://www.versobooks.com/blogs?mentioned_book=3671>. Acesso em: 14 dez. 2016.

Disponivel em: <http://www.revistatropico.com.br/tropico/html/textos/956,1.shl>. Acesso em: 02 mai. 2015.

Disponível em: <http://www.canalcontemporaneo.art.br/enformes.php?codigo=637>. Acesso em: 29 dez. 2014.

Disponível em: <http://www.30xbienal.org.br/single/114>. Acesso em 20 out. 2017.

Disponível em: <http://www.canalcontemporaneo.art.br/saloesepremios/archives/2007_09.html>. Acesso em: 20 out. 2017.

Disponível em: <https://www.documenta.de/en/retrospective/documenta_x>. Acesso em: 12 out. 2017.

Disponível em: <https://www.documenta.de/en/retrospective/documenta11>. Acesso em 12out. 2017.

Disponível em: <https://www.documenta.de/en/retrospective/documenta_12>. Acesso em 12 out. 2017.

Disponível em: <https://www.documenta.de/en/retrospective/documenta_13>. Acesso em 12 out. 2017.

Disponivel em: <http://buscatextual.cnpq.br/buscatextual/visualizacv.do?id=K4269306P6>. Acesso em 29 out. 2017.

Disponível em: <http://www.revistatropico.com.br/tropico/html/textos/1770,1.shl>. Acesso em: 20 out. 2017.

Disponivel em: <http://gazetaonline.globo.com/_conteudo/2008/12/44285-

obras+da+bienal+do+mar+interagem+com+paisagem+do+centro+de+vitoria.html>. Acesso em: 03 abr. 2014.

Disponível em: <http://lojasdemuseus.blogspot.com.br/2009/12/mammuseudeartecontemporanea_04.html>. Acesso em: 07 set. 2015.

Disponivel em: <http://www1.folha.uol.com.br/folha/ilustrada/ult90u48592.shtml>. Acesso em: 02 nov. 2017.

Disponível em: <http://www.bienal.org.br/exposicao.php?i=2343>. Acesso em: 03 nov. 2017.

Disponivel em: <http://www.secult.es.gov.br/patrimonios/naturais>. Acesso em: 10 ago. 2016.

Disponível em: <http://universo.ufes.br/blog/2016/04/aquaviario-o-fantasma-que-assombra-os-mares-vitoria/> . Acesso em: 16 ago. 2017.

Disponivel em: <http://madridabierto.com/textos/2011-2012/10-anos-madrid-abierto.html>. Acesso em: 19 dez. 2017.

Disponível em: <http://www.democracia.com.es/proyectos/virtual-demolition-mobile/>. Acesso em: 20 mai. 2017. Disponível em: <http://marintimomar.blogspot.com.br/2008/>. Acesso em: 20 mai. 2017. 


\section{WEBSITE}

canalvaginalcontemporaneo@yahoo.com.br,

URL

url: http://br.groups.yahoo.com/group/paralelaaomar/.

url: http://www.multipliCIDADE2006.blogspot.com.br/.

url: www.entretantos.tk/.

url: http://orkut.google.com/c19305206.html. 